\title{
Coal Geology and Assessment of Resources and Reserves in the Little Snake River Coal Field and Red Desert Assessment Area, Greater Green River Basin, Wyoming
}

$47+\frac{1}{d 0} \geq 8$

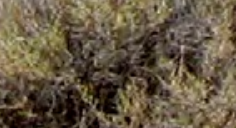

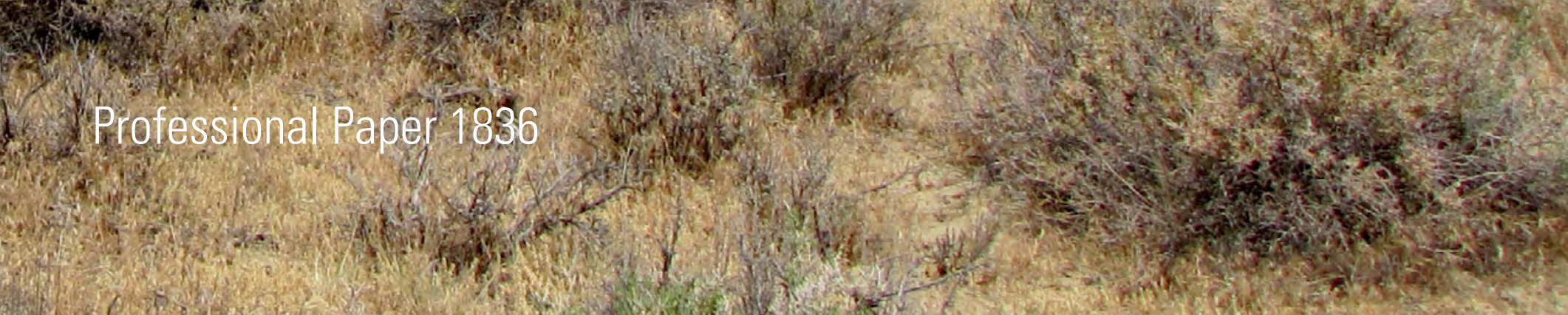

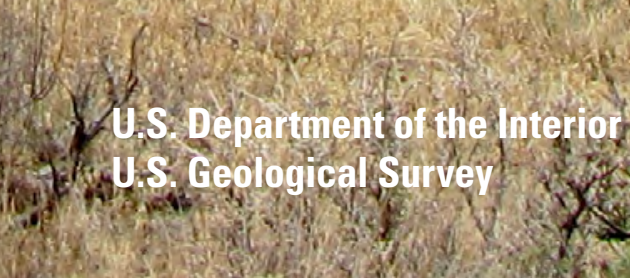

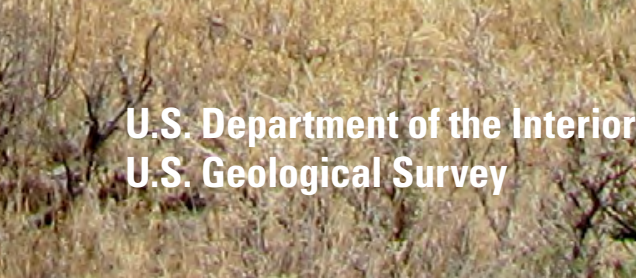

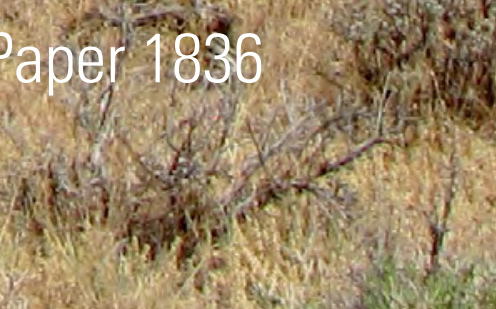

Hin

to 010 a 
Cover. Fort Union Formation in the Little Snake River area, Wyoming (Photograph by Jon Haacke, U.S. Geological Survey). 


\section{Coal Geology and Assessment of Resources and Reserves in the Little Snake River Coal Field and Red Desert Assessment Area, Greater Green River Basin, Wyoming}

By David C. Scott, Brian N. Shaffer, Jon E. Haacke, Paul E. Pierce, and Scott A. Kinney

Professional Paper 1836 


\title{
U.S. Department of the Interior DAVID BERNHARDT, Secretary
}

\author{
U.S. Geological Survey \\ James F. Reilly II, Director
}

\section{U.S. Geological Survey, Reston, Virginia: 2019}

For more information on the USGS - the Federal source for science about the Earth, its natural and living resources, natural hazards, and the environment—visit https://www.usgs.gov or call 1-888-ASK-USGS.

For an overview of USGS information products, including maps, imagery, and publications, visit https://store.usgs.gov.

Any use of trade, firm, or product names is for descriptive purposes only and does not imply endorsement by the U.S. Government.

Although this information product, for the most part, is in the public domain, it also may contain copyrighted materials as noted in the text. Permission to reproduce copyrighted items must be secured from the copyright owner.

Suggested citation:

Scott, D.C., Shaffer, B.N., Haacke, J.E., Pierce, P.E., and Kinney, S.A., 2019, Coal geology and assessment of coal resources and reserves in the Little Snake River coal field and Red Desert assessment area, Greater Green River Basin, Wyoming: U.S. Geological Survey Professional Paper 1836, 169 p., https://doi.org/10.3133/pp1836.

ISSN 2330-7102 (online) 


\section{Contents}

Abstract

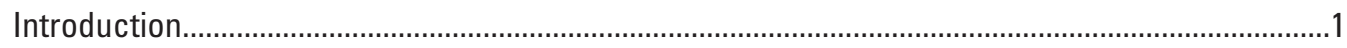

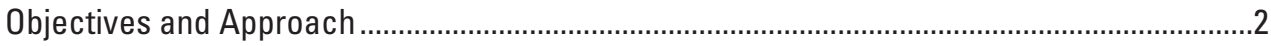

Previous Investigations and Resource Estimates ................................................................2

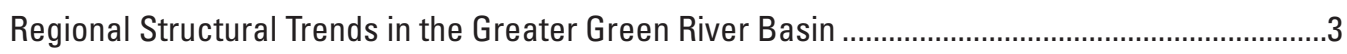

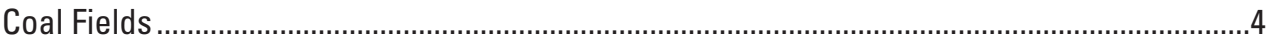

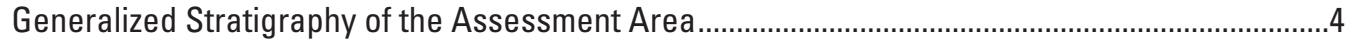

Previous and Current Coal Mining ............................................................................................

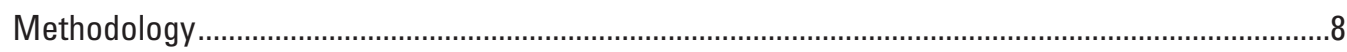

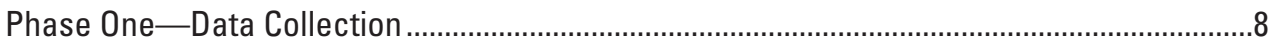

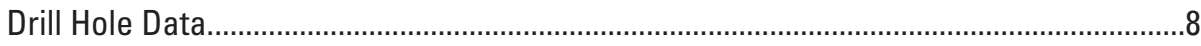

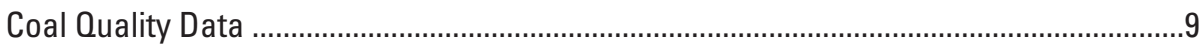

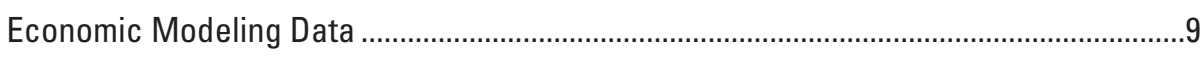

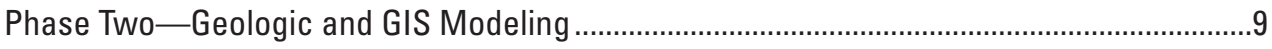

Coal Bed Correlations ...............................................................................................

Coal Bed Modeling ……...............................................................................................

Coal Bed Assessment ........................................................................................................

Wasatch Formation ..................................................................................................11

Luman Coal Zone (Niland Tongue) ................................................................................

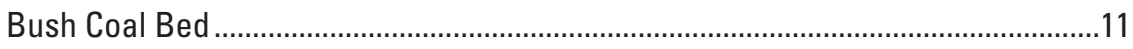

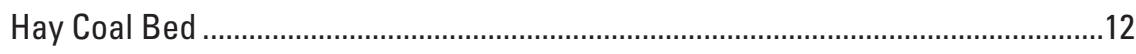

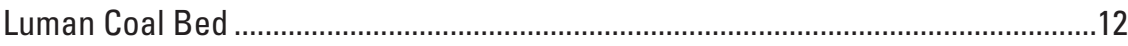

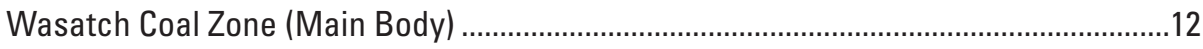

Upper Battle and Battle Coal Beds.......................................................................12

Upper Monument, Monument, and Lower Monument Coal Beds...........................12

Upper and Lower Sourdough Coal Beds ..............................................................13

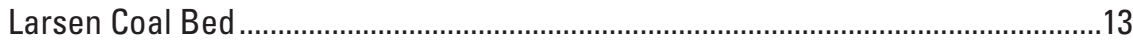

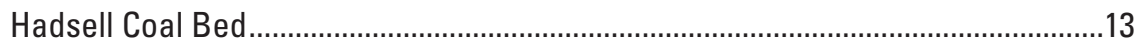

Upper Creston, Creston, and Lower Creston Coal Beds ..........................................13

Upper Latham, Latham, and Lower Latham Coal Beds .........................................14

Unnamed \#1 and Unnamed \#2 Coal Beds .............................................................14

Fort Union Formation ..........................................................................................................

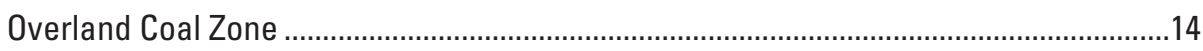

High Point Coal Bed...................................................................................... 15

Upper Cherokee, Cherokee, and Lower Cherokee Coal Beds ................................15

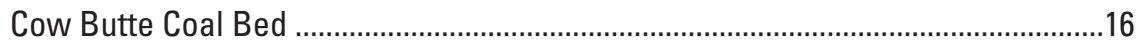

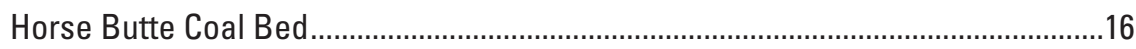

China Butte Coal Zone ...............................................................................................16

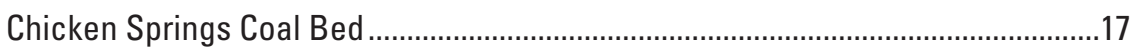

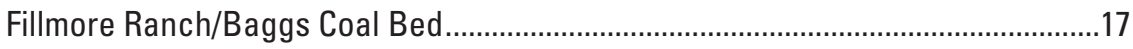

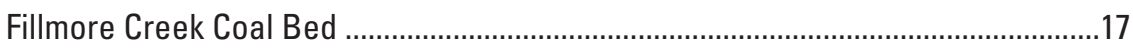

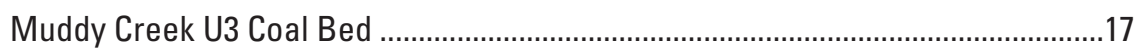

Muddy Creek/Five Mile Point Coal Bed ................................................................18 
Separation Creek, Separation Creek B, and Lower Separation Creek Coal Beds.18

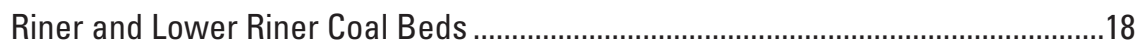

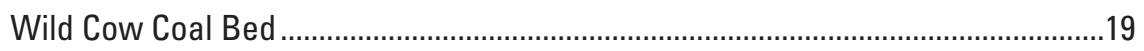

Upper Olson Draw, Olson Draw, and Lower Olson Draw Coal Beds.......................19

Hadsell Draw Coal Bed......................................................................................19

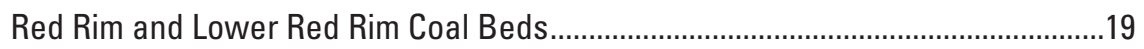

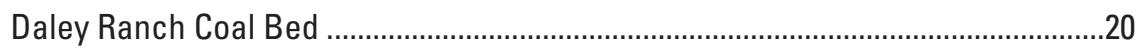

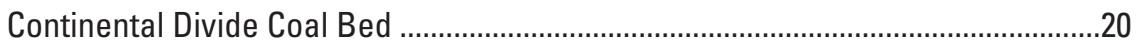

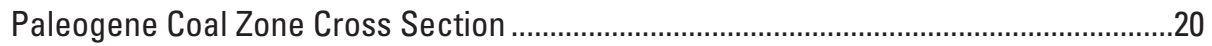

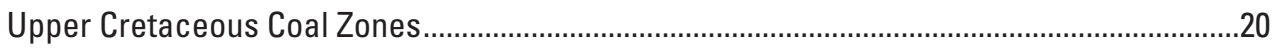

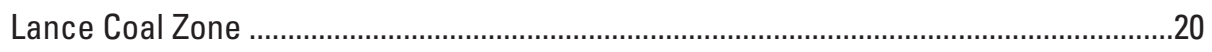

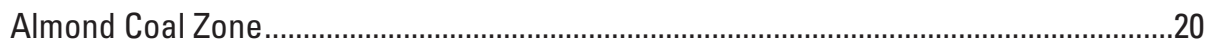

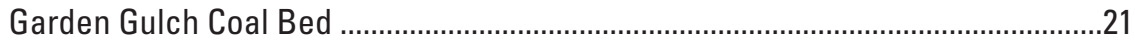

Upper JO Ranch Coal Bed.....................................................................................

JO Ranch Coal Bed........................................................................................2

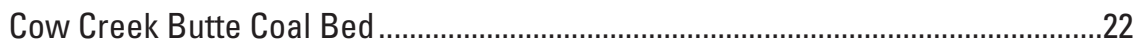

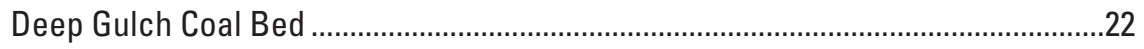

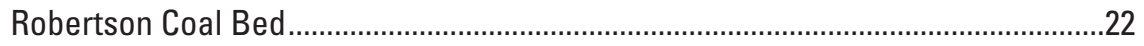

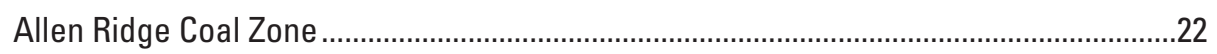

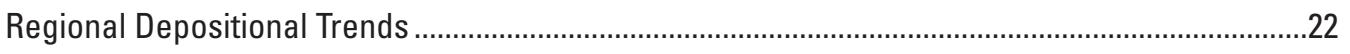

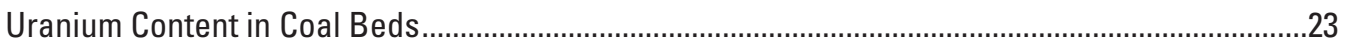

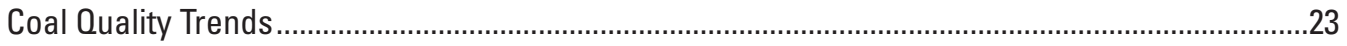

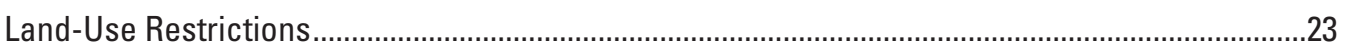

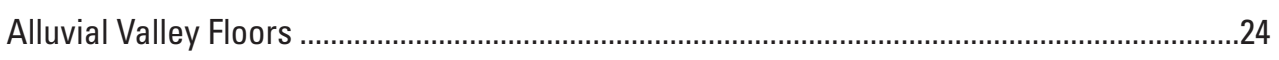

Coalbed Methane

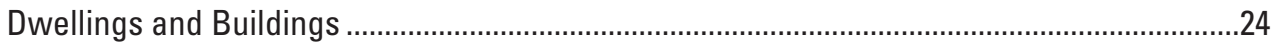

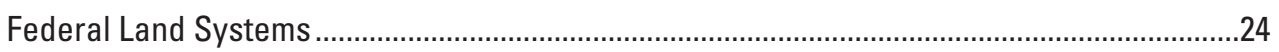

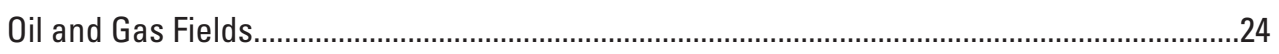

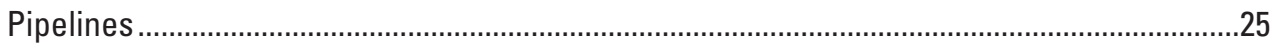

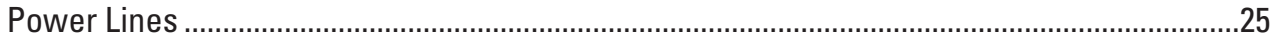

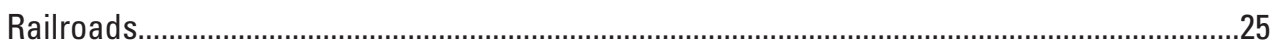

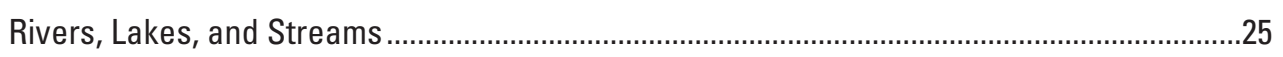

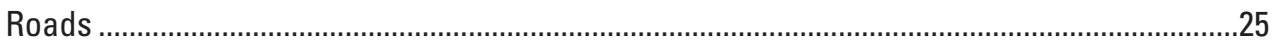

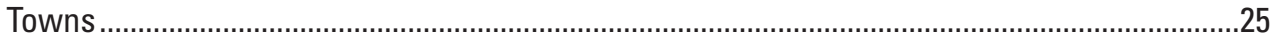

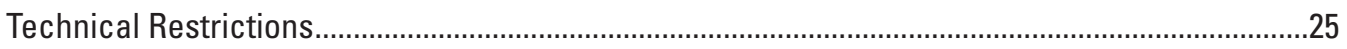

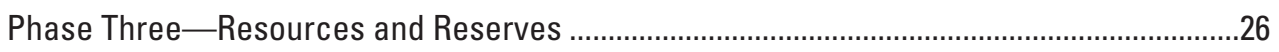

Coal Resource Assessment Methodology …………................................................26

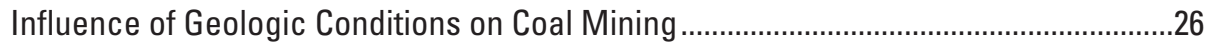

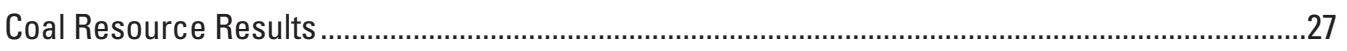

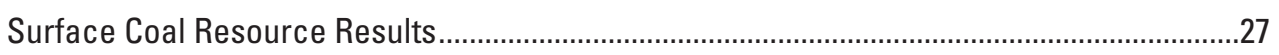

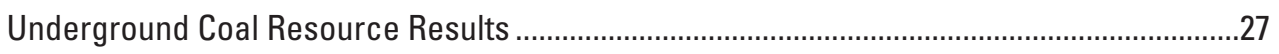

Economic Modeling for Coal Reserve Assessment..............................................................28

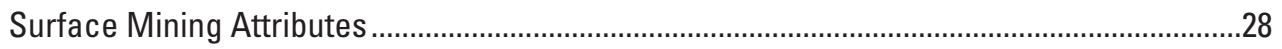

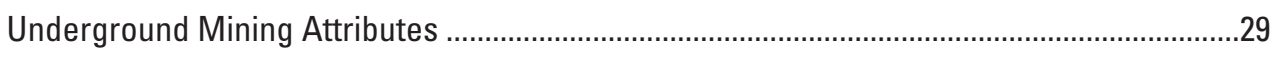

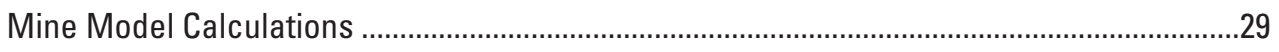


Economic Considerations for the Mining Project Simulation ................................................29

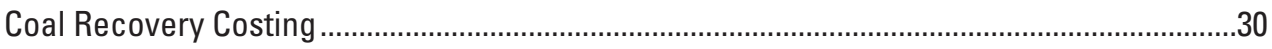

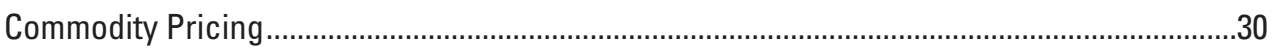

Discounted Cash Flow for Coal Assessment ...........................................................................30

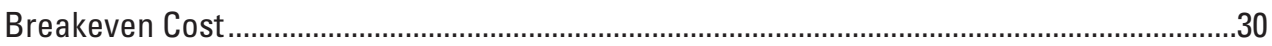

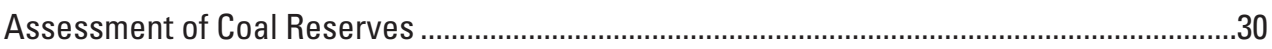

Surface Mine Reserve Evaluation Results ............................................................................

Underground Mine Reserve Evaluation Results.......................................................................

U.S. Geological Survey Classification of Coal Resources and Reserves .................................31

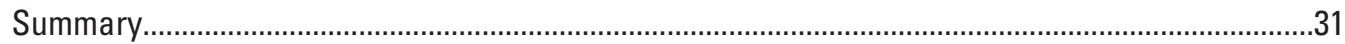

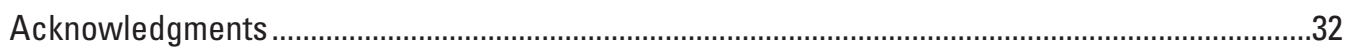

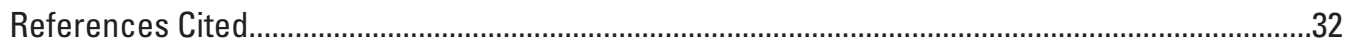

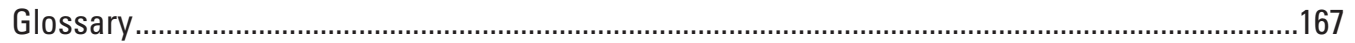

\section{Figures}

1. Map showing locations of the Little Snake River coal field and the Red Desert assessment area, subbasins, and major structural features in the Greater Green River Basin, Wyoming ............................................................................................40

2. Map showing approximate locations of structural and geographic features in the Little Snake River coal field and Red Desert assessment area in the Greater Green River Basin, Wyoming

3. Flow chart showing generalized U.S. Geological Survey methodology used for coal resource and reserve assessment

4-8. Maps showing:

4. Location of uranium-bearing coal areas in the Little Snake River coal field and Red Desert assessment area in the Greater Green River Basin, Wyoming.....43

5. Outline location of 23 quadrangles for coal resource occurrence and coal development potential reports (Dames and Moore Company, 1978a-g, 1979a-p) in the Little Snake River coal field and Red Desert assessment area in the Greater Green River Basin, Wyoming.

6. Structure contours drawn at the top of the Mesaverde Group in the Greater Green River Basin, Wyoming ............................................................................... 45

7. Location of coal fields in the Greater Green River Basin, Wyoming.........................46

8. Generalized geology of the Little Snake River coal field and Red Desert assessment area, Greater Green River Basin, Wyoming ...

9. A, Generalized stratigraphic column, showing age, units, description of units, and maximum thickness of units for the Little Snake River coal field and Red Desert assessment area, Wyoming; $B$, Generalized geologic cross-section showing the intertonguing relations of the Battle Spring, Wasatch, and Green River Formations because of lateral facies changes in the Little Snake River coal field and Red Desert assessment area, Greater Green River Basin, Wyoming

10. Stratigraphic column showing age, formation name, coal-bearing thickness, bed name, resources, reserves, number of drill holes, and maximum and median thicknesses of coal beds in the Little Snake River coal field and Red Desert assessment area, Greater Green River Basin, Wyoming 
11-16. Maps showing:

11. Structure contours drawn at the top of the Fillmore Ranch/Baggs coal bed within the Little Snake River coal field and Red Desert assessment area, Greater Green River Basin, Wyoming .....

12. Approximate locations of coal lease application areas in the Little Snake River coal field and Red Desert assessment area, Greater Green River Basin, Wyoming

13. Approximate locations of abandoned mines in the Little Snake River coal field and Red Desert assessment area, Greater Green River Basin, Wyoming ......53

14. Drill hole locations in the Little Snake River coal field and Red Desert assessment area, Greater Green River Basin, Wyoming

15. Coal zone extents and locations of deposition centers in the $A$, Wasatch, $B$, Overland, $C$, China Butte, and $D$, Almond coal zones in the Little Snake River coal field and Red Desert assessment area, Greater Green River Basin, Wyoming

16. Composite thickness of all coal beds in the Wasatch coal zone within the Little Snake River coal field and Red Desert assessment area, Greater Green River Basin, Wyoming.....

17. Generalized stratigraphic column showing coal beds in the Wasatch Formation coal zone in the Little Snake River coal field and Red Desert assessment area, Greater Green River Basin, Wyoming

18. West-east cross section $A-A$ ' showing approximate subsurface distribution of coal beds in the Wasatch Formation in the Little Snake River coal field and Red Desert assessment area, Greater Green River Basin, Wyoming

19. South-north cross section $B-B^{\prime}$ showing approximate subsurface distribution of coal beds in the Wasatch Formation in the Little Snake River coal field and Red Desert assessment area, Greater Green River Basin, Wyoming ....

20. Southwest-northeast cross section $C-C$ showing approximate subsurface distribution of coal beds in the Wasatch Formation in the Little Snake River coal field and Red Desert assessment area, Greater Green River Basin, Wyoming...

21-39. Maps showing:

21. Monument coal bed showing extent of coal within the Little Snake River coal field and Red Desert assessment area, Greater Green River Basin, Wyoming

22. Depth to the top of the Monument coal bed within the Little Snake River coalfield and Red Desert assessment area, Greater Green River Basin, Wyoming

23. Upper Sourdough coal bed showing extent of coal within the Little Snake River coal field and Red Desert assessment area, Greater Green River Basin, Wyoming

24. Depth to the top of the Upper Sourdough coal bed within the Little Snake Rivercoal field and Red Desert assessment area, Greater Green River Basin, Wyoming

25. Lower Sourdough coal bed showing extent of coal within the Little Snake Rivercoal field and Red Desert assessment area, Greater Green River Basin, Wyoming

26. Depth to the top of the Lower Sourdough coal bed within the Little Snake River coal field and Red Desert assessment area, Greater Green River Basin, Wyoming 
27. Larsen coal bed showing extent of coal within the Little Snake River coal field and Red Desert assessment area, Greater Green River Basin, Wyoming ......67

28. Depth to the top of the Larsen coal bed within the Little Snake River coal field and Red Desert assessment area, Greater Green River Basin, Wyoming

29. Creston coal bed showing extent of coal within the Little Snake River coal field and Red Desert assessment area, Greater Green River Basin, Wyoming

30. Depth to the top of the Creston coal bed within the Little Snake River coal field and Red Desert assessment area, Greater Green River Basin, Wyoming

31. Lower Creston coal bed showing extent of coal within the Little Snake River coal field and Red Desert assessment area, Greater Green River Basin, Wyoming

32. Depth to the top of the Lower Creston coal bed within the Little Snake River coal field and Red Desert assessment area, Greater Green River Basin, Wyoming

33. Upper Latham coal bed showing extent of coal within the Little Snake River coal field and Red Desert assessment area, Greater Green River Basin, Wyoming

34. Depth to the top of the Upper Latham coal bed within the Little Snake River coal field and Red Desert assessment area, Greater Green River Basin, Wyoming

35. Latham coal bed showing extent of coal within the Little Snake River coal field and Red Desert assessment area, Greater Green River Basin, Wyoming

36. Depth to the top of the Latham coal bed within the Little Snake River coal field and Red Desert assessment area, Greater Green River Basin, Wyoming

37. Unnamed 2 coal bed showing extent of coal within the Little Snake River coal field and Red Desert assessment area, Greater Green River Basin, Wyoming

38. Depth to the top of the Unnamed 2 coal bed within the Little Snake River coal field and Red Desert assessment area, Greater Green River Basin, Wyoming

39. Composite thickness of all coal beds in the Overland coal zone of the Fort Union Formation within the Little Snake River coal field and Red Desert assessment area, Greater Green River Basin, Wyoming

40. Generalized stratigraphic column showing coal beds in the Overland coal zone of the Fort Union Formation in the Little Snake River coal field and Red Desert assessment area, Greater Green River Basin, Wyoming

41. Northwest-southeast cross section $D-D^{\prime}$ showing approximate subsurface distribution of coal beds in the Overland coal zone in the Little Snake River coal field and Red Desert assessment area, Greater Green River Basin, Wyoming...

42. Southwest-northeast cross section $E-E$ showing approximate subsurface distribution of coal beds in the Overland coal zone in the Little Snake River coal field and Red Desert assessment area, Greater Green River Basin, Wyoming...

43. Cross section $F-F$ showing splitting of the Cherokee bed in the Overland coal zone in the Little Snake River coal field and Red Desert assessment area, Greater Green River Basin, Wyoming . 
44-54. Maps of the:

44. Upper Cherokee coal bed showing extent of coal within the Little Snake River coal field and Red Desert assessment area, Greater Green River Basin, Wyoming.....

45. Depth to the top of the Upper Cherokee coal bed within the Little Snake River coal field and Red Desert assessment area, Greater Green River Basin, Wyoming . .85

46. Cherokee coal bed showing extent of coal within the Little Snake River coal field and Red Desert assessment area, Greater Green River Basin, Wyoming ......86

47. Depth to the top of the Cherokee coal bed within the Little Snake River coal field and Red Desert assessment area, Greater Green River Basin, Wyoming ......87

48. Lower Cherokee coal bed showing extent of coal within the Little Snake River coal field and Red Desert assessment area, Greater Green River Basin, Wyoming 88

49. Depth to the top of the Lower Cherokee coal bed within the Little Snake River coal field and Red Desert assessment area, Greater Green River Basin, Wyoming

50. Cow Butte coal bed showing extent of coal within the Little Snake River coal field and Red Desert assessment area, Greater Green River Basin, Wyoming..........90

51. Depth to the top of the Cow Butte coal bed within the Little Snake River coal field and Red Desert assessment area, Greater Green River Basin, Wyoming..........91

52. Horse Butte coal bed showing extent of coal within the Little Snake River coal field and Red Desert assessment area, Greater Green River Basin, Wyoming .........92

53. Depth to the top of the Horse Butte coal bed within the Little Snake River coal field and Red Desert assessment area, Greater Green River Basin, Wyoming .........93

54. Composite thickness of all coal beds in the China Butte coal zone within the Little Snake River coal field and Red Desert assessment area, Greater Green River Basin, Wyoming...

55. Generalized stratigraphic column showing coal beds in the China Butte coal zone in the Little Snake River coal field and Red Desert assessment area, Greater Green River Basin, Greater Green River Basin, Wyoming

56. West-east cross section $G-G$ showing approximate subsurface distribution of coal beds in the China Butte coal zone in the Little Snake River coal field and Red Desert assessment area, Greater Green River Basin, Wyoming.....

57. Southwest-northeast cross section $H-H^{\prime}$ showing approximate subsurface distribution of coal beds in the China Butte coal zone in the Little Snake River coal field and Red Desert assessment area, Greater Green River Basin, Wyoming.

58. West-east cross section $l-l$ ' showing approximate subsurface distribution of coal beds in the China Butte coal zone in the Little Snake River coal field and Red Desert assessment area, Greater Green River Basin, Wyoming ....

59-84. Maps showing:

59. Chicken Springs coal bed showing extent of coal within the Little Snake River coal field and Red Desert assessment area, Greater Green River Basin, Wyoming .99

60. Depth to the top of the Chicken Springs coal bed within the Little Snake River coal field and Red Desert assessment area, Greater Green River Basin, Wyoming 
61. Fillmore Ranch/Baggs coal bed showing extent of coal within the Little Snake River coal field and Red Desert assessment area, Greater Green River Basin, Wyoming

62. Depth to the top of the Fillmore Ranch/Baggs coal bed within the Little Snake River coal field and Red Desert assessment area, Greater Green River Basin, Wyoming

63. Fillmore Creek coal bed showing extent of coal within the Little Snake River coal field and Red Desert assessment area, Greater Green River Basin, Wyoming.

64. Depth to the top of the Fillmore Creek coal bed within the Little Snake River coal field and Red Desert assessment area, Greater Green River Basin, Wyoming.....

65. Muddy Creek/Five Mile Point coal bed showing extent of coal within the Little Snake River coal field and Red Desert assessment area, Greater Green River Basin, Wyoming...

66. Depth to the top of the Muddy Creek/Five Mile Point coal bed within the Little Snake River coal field and Red Desert assessment area, Greater Green River Basin, Wyoming

67. Separation Creek B coal bed showing extent of coal within the Little Snake River coal field and Red Desert assessment area, Greater Green River Basin, Wyoming

68. Depth to the top of the Separation Creek B coal bed within the Little Snake River coal field and Red Desert assessment area, Greater Green River Basin, Wyoming

69. Lower Separation Creek coal bed showing extent of coal within the Little Snake River coal field and Red Desert assessment area, Greater Green River Basin, Wyoming

70. Depth to the top of the Lower Separation Creek coal bed within the Little Snake River coal field and Red Desert assessment area, Greater Green River Basin, Wyoming

71. Riner coal bed showing extent of coal within the Little Snake River coal field and Red Desert assessment area, Greater Green River Basin, Wyoming

72. Depth to the top of the Riner coal bed within the Little Snake River coal field and Red Desert assessment area, Greater Green River Basin, Wyoming

73. Lower Riner coal bed showing extent of coal within the Little Snake River coal field and Red Desert assessment area, Greater Green River Basin, Wyoming

74. Depth to the top of the Lower Riner coal bed within the Little Snake River coal field and Red Desert assessment area, Greater Green River Basin, Wyoming

75. Wild Cow coal bed showing extent of coal within the Little Snake River coal field and Red Desert assessment area, Greater Green River Basin, Wyoming........... 115

76. Depth to the top of the Wild Cow coal bed within the Little Snake River coal field and Red Desert assessment area, Greater Green River Basin, Wyoming ........... 116

77. Olson Draw coal bed showing extent of coal within the Little Snake River coal field and Red Desert assessment area, Greater Green River Basin, Wyoming

78. Depth to the top of the Olson Draw coal bed within the Little Snake River coal field and Red Desert assessment area, Greater Green River Basin, Wyoming 
79. Lower Olson Draw coal bed showing extent of coal within the Little Snake River coal field and Red Desert assessment area, Greater Green River Basin, Wyoming...

80. Depth to the top of the Lower Olson Draw coal bed within the Little Snake River coal field and Red Desert assessment area, Greater Green River Basin, Wyoming

81. Red Rim coal bed showing extent of coal within the Little Snake River coal field and Red Desert assessment area, Greater Green River Basin, Wyoming 121

82. Depth to the top of the Red Rim coal bed within the Little Snake River coal field and Red Desert assessment area, Greater Green River Basin, Wyoming

83. Daley Ranch coal bed showing extent of coal within the Little Snake River coal field and Red Desert assessment area, Greater Green River Basin, Wyoming

84. Depth to the top of the Daley Ranch coal bed within the Little Snake River coal field and Red Desert assessment area, Greater Green River Basin, Wyoming

85. Northwest-southeast cross section $J-J$ ' showing approximate subsurface distribution of Paleogene coal zones in the Little Snake River coal field and Red Desert assessment area, Greater Green River Basin, Wyoming

86. Maps showing composite thickness of all coal beds in the Lance coal zone within the Little Snake River coal field and Red Desert assessment area, Greater Green River Basin, Wyoming

87. Maps showing composite thickness of all coal beds in the Almond coal zone within the Little Snake River coal field and Red Desert assessment area, Greater Green River Basin, Wyoming

88. Generalized stratigraphic column showing coal beds in the Almond Formation in the Little Snake River coal field and Red Desert assessment area, Greater Green River Basin, Wyoming

89. Southwest-northeast cross section $K-K$ showing approximate subsurface distribution of coal beds in the Almond Formation in the Little Snake River coal field and Red Desert assessment area, Greater Green River Basin, Wyoming.

90-103. Maps showing:

90. Garden Gulch coal bed showing extent of coal within the Little Snake River coal field and Red Desert assessment area, Greater Green River Basin, Wyoming

91. Depth to the top of the Garden Gulch coal bed within the Little Snake River coal field and Red Desert assessment area, Greater Green River Basin, Wyoming

92. Upper JO Ranch coal bed showing extent of coal within the Little Snake River coal field and Red Desert assessment area, Greater Green River Basin, Wyoming

93. Depth to the top of the Upper JO Ranch coal bed within the Little Snake River coal field and Red Desert assessment area, Greater Green River Basin, Wyoming

94. JO Ranch coal bed showing extent of coal within the Little Snake River coal field and Red Desert assessment area, Greater Green River Basin, Wyoming 
95. Depth to the top of the JO Ranch coal bed within the Little Snake River coal field and Red Desert assessment area, Greater Green River Basin, Wyoming

96. Cow Creek Butte coal bed showing extent of coal within the Little Snake River coal field and Red Desert assessment area, Greater Green River Basin, Wyoming

97. Depth to the top of the Cow Creek Butte coal bed within the Little Snake River coal field and Red Desert assessment area, Greater Green River Basin, Wyoming

98. Deep Gulch coal bed showing extent of coal within the Little Snake River coal field and Red Desert assessment area, Greater Green River Basin, Wyoming

99. Depth to the top of the Deep Gulch coal bed within the Little Snake River coal field and Red Desert assessment area, Greater Green River Basin, Wyoming

100. Robertson coal bed showing extent of coal within the Little Snake River coal field and Red Desert assessment area, Greater Green River Basin, Wyoming

101. Depth to the top of the Robertson coal bed within the Little Snake River coal field and Red Desert assessment area, Greater Green River Basin, Wyoming

102. Approximate locations of Greater Wamsutter oil and gas field, Interstate 80, and railroad land-use restrictions in the Little Snake River coal field and Red Desert assessment area, Greater Green River Basin, Wyoming

103. Mineral estate ownership in the Little Snake River coal field and Red Desert assessment area, Greater Green River Basin, Wyoming

104. Illustration showing the effect of increasing coal bed depth upon restricted resource from mine-pit highwall setback requirements.

105. Pie diagram showing tonnages and percentages of coal zones in relation to the 73.2 billion short tons of original resources in the Little Snake River coal field and Red Desert assessment area, Greater Green River Basin, Wyoming

106-109 Graphs showing:

106. Cumulative cost curve for two coal beds in the Wasatch coal zone, using sales price per short ton to delineate recoverable resources and reserves

107. Cumulative cost curve for two coal beds in the Overland coal zone, using sales price per short ton to delineate recoverable resources and reserves.

108. Cumulative cost curve for two coal beds in the China Butte coal zone, using sales price per short ton to delineate recoverable resources and reserves........146

109. Cumulative cost curve for two coal beds in the Almond coal zone, using sales price per short ton to delineate recoverable resources and reserves. 146

110. Flow chart showing the classification of coal resources and reserves used by the U.S. Geological Survey in coal assessment studies 


\section{Tables}

1. Original surface and underground resources in the Little Snake River coal field and Red Desert assessment area, Greater Green River Basin, Wyoming...

2. Typical proximate analysis on a raw, as-received basis reporting calorific value, moisture, sulfur, ash, fixed carbon, and volatile matter for coal beds in the Little Snake River coal field and Red Desert assessment area, Greater Green River Basin, Wyoming .....

3. Original coal resources, recoverable coal resources, restrictions, and reliability classifications for 33 coal beds in the Little Snake River coal field and Red Desert assessment area, Greater Green River Basin, Wyoming ...

4. Recoverable coal resources and classification by coal ownership for 33 coal beds in the Little Snake River coal field and Red Desert assessment area, Greater Green River Basin, Wyoming ....

5. Summary of original and recoverable coal resources, restrictions, reliability classifications, and geologic uinti for 33 coal beds in the Little Snake River coal field and Red Desert assessment area, Greater Green River Basin Wyoming.

6. Projected surface mine breakeven costs and estimated prices for run-of-mine coal for coal beds in the Little Snake River coal field and Red Desert assessment area, Greater Green River Basin, Wyoming

7. Recoverable coal resources by stripping ratio for coal beds containing more than 40 million short tons in the Little Snake River coal bed and Red Desert assessment area, Greater Green River Basin, Wyoming ...

8. Geotechnical correlations between Hanna Basin and Little Snake River coal field and Red Desert assessment area, Greater Green River Basin, Wyoming

9. Average weekly coal commodity spot prices 


\section{Conversion Factors}

U.S. customary units to International System of Units

\begin{tabular}{lll}
\hline \multicolumn{1}{c}{ Multiply } & \multicolumn{1}{c}{ By } & \multicolumn{1}{c}{ To obtain } \\
\hline foot $(\mathrm{ft})$ & 0.3048 & meter $(\mathrm{m})$ \\
mile $(\mathrm{mi})$ & 1.609 & kilometer $(\mathrm{km})$ \\
square foot $\left(\mathrm{ft}^{2}\right)$ & 0.09290 & square meter $\left(\mathrm{m}^{2}\right)$ \\
square mile $\left(\mathrm{mi}^{2}\right)$ & 2.590 & square kilometer $\left(\mathrm{km}^{2}\right)$ \\
acre-foot $(\mathrm{acre}-\mathrm{ft})$ & 1,770 & ton, short $(2,000 \mathrm{lb})^{*}$ \\
pound, avoirdupois $(\mathrm{lb})$ & 0.4536 & kilogram $(\mathrm{kg})$ \\
ton, short $(\mathrm{ST} ; 2,000 \mathrm{lb})$ & 0.9072 & metric ton $(\mathrm{t})$ \\
pound per square inch $\left(\mathrm{lb} / \mathrm{in}^{2}\right)$ & 6.895 & kilopascal $(\mathrm{kPa})$ \\
pound per cubic foot $\left(\mathrm{lb} / \mathrm{ft}^{3}\right)$ & 16.02 & kilogram per cubic meter $\left(\mathrm{kg} / \mathrm{m}^{3}\right)$ \\
British thermal unit $(\mathrm{Btu})$ & 0.000293 & kilowatt $(\mathrm{kW})$ \\
British thermal unit per pound $(\mathrm{Btu} / \mathrm{lb})$ & 2.326 & kilojoule per kilogram $(\mathrm{kJ} / \mathrm{km})$ \\
\hline
\end{tabular}

"Used only for conversions of volume of subbituminous coal.

As used in this report, "million" means $\times 10^{6}$ and "billion" means $\times 10^{9}$.

\section{Datum}

Vertical coordinate information is referenced to the North American Vertical Datum of 1988 (NAVD 88). Horizontal coordinate information is referenced to the North American Datum of 1983 (NAD 83). Elevation, as used in this report, refers to distance above the vertical datum. 



\title{
Coal Geology and Assessment of Resources and Reserves in the Little Snake River Coal Field and Red Desert Assessment Area, Greater Green River Basin, Wyoming
}

\author{
By David C. Scott, Brian N. Shaffer, Jon E. Haacke, Paul E. Pierce, and Scott A. Kinney
}

\section{Abstract}

The U.S. Geological Survey is studying regional-scale assessments of resources and reserves of primary coal beds in the major coal bed basins in the United States to help formulate policy for Federal, State, and local energy and land use. This report summarizes the geology and coal resources and reserves in the Little Snake River coal field and Red Desert assessment area in the Greater Green River Basin, southwestern Wyoming. These areas are contiguous and referred to as the "assessment area" in this report. The assessment area covers about 2,300 square miles of the eastern section of the 15,400-square-mile Greater Green River Basin. This area was prioritized for assessment because no comprehensive resource assessment had previously been completed in the area; abundant, previously unavailable drill hole data from cooperators and stakeholders became available; and there are active coal mines in the Greater Green River Basin area producing from some of the same formations as those found in the assessment area.

Coal-bearing Eocene, Paleocene, and Upper Cretaceous formations have a composite thickness of more than 11,000 feet in the assessment area. Stratigraphic sequences that contain multiple coal beds within a formation or member are referred to as coal zones in this report. Paleogene coal beds are found within coal zones in the Eocene Wasatch Formation and the Paleocene Fort Union Formation. Cretaceous coal beds are within coal zones in the Lance, Almond, and Allen Ridge Formations.

A total of 4,214 drill holes and measured sections were used to construct a geologic database for this assessment. From these data, 7 coal zones containing 55 individual coal beds were identified. Not all 55 coal beds were assessed; only those beds that were at least 3 feet thick and had at least a 2-square-mile areal extent were considered. Using a geology-based assessment methodology, the U.S. Geological Survey estimated original, available, and recoverable coal resources for 33 coal beds that met those criteria.

An original resource of 73.2 billion short tons of coal was calculated for the 33 coal beds that met the criteria in the assessment area. To be considered extractable by surface mining methods, coal beds had to be equal to or greater than 3 feet thick and less than 300 feet deep. Of the 73.2 billion short tons (BST), 19.3 BST were determined to be recoverable resources, of which approximately 2.1 BST were considered as recoverable resources by surface mining methods at a stripping ratio of 10:1 or less. (defined as recoverable resources for this assessment, based on economic modeling and regional mining analogs). Recoverable resources for underground mining methods (coal 8 to 15 feet thick and between 300 and 3,000 feet deep) totaled 17.2 BST. Out of the 19.3 BST assessed as recoverable coal resources, approximately 167 million short tons (MST) were considered to be reserves.

Within the 7 coal zones, the Wasatch coal zone contains an original resource of about 6.8 BST billion short tons of coal, of which 2.6 BST are considered a recoverable resource and approximately 26.7 MST are considered reserves. The Overland coal zone, in the Fort Union Formation, contains an original resource of approximately $23 \mathrm{BST}$ of coal, of which 8.4 BST are considered a recoverable resource and approximately 74 MST are considered reserves. The China Butte coal zone, in the Fort Union Formation, contains an original resource of 36.2 BST of coal, of which 6.3 BST are considered a recoverable resource and approximately 5.5 MST are considered reserves. The Almond coal zone, in the Almond Formation, contains an original resource of 7.0 BST, of which approximately 2.0 BST are considered a recoverable resource and $61 \mathrm{MST}$ are considered reserves. Resources were not calculated for the coal zones within the Niland Tongue of the Wasatch Formation or the Cretaceous Lance and Allen Ridge Formations because the coal beds in those zones are relatively thin, discontinuous, and have a limited areal extent.

\section{Introduction}

In the greater context of a nationwide set of regional-scale coal resource and coal reserve assessments of coal beds in major coal basins in the United States to aid in formulating policy for Federal, State, and local energy and land use, the U.S. Geological Survey (USGS) initiated a national coal resource assessment of in-place coal resources (Pierce and Dennen, 2009). These assessments, however, did not provide all the information needed for resource planning, because they did not include estimates and calculations of the recoverable part of remaining coal resources. 
Confusion often exists concerning the use of the terms "resources" and "reserves" as they relate to coal assessments. Although the two terms have been used interchangeably, there are important differences in their meaning. Coal resources include those in-place tonnage estimates determined by summing the volumes for identified and hypothetical coal beds and coal zones of a minimum thickness and within certain depth limits (Pierce and Dennen, 2009). Coal reserves are a subset of coal resources considered economically minable at the time of classification (Wood and others, 1983).

The Powder River Basin in Wyoming and Montana was the first regional coal resource and reserve assessment in the United States (Luppens and others, 2015). The second region to be assessed is the Greater Green River Basin in southwestern Wyoming (fig. 1). This report summarizes the geology, coal resources, and reserves in the Little Snake River coal field and Red Desert assessment area within the Greater Green River Basin (figs. 1 and 2). These areas are contiguous and will be referred to as the "assessment area" in this report.

The east-west course of U.S. Interstate 80 (I-80) divides the assessment area into two parts (figs. 1 and 2). For this report, the northern part is referred to as the Red Desert assessment area and the southern part is referred to as the Little Snake River coal field. The areal extent of the assessment area is approximately 2,300 square miles $\left(\mathrm{mi}^{2}\right)$ of the eastern portion of the $15,400-\mathrm{mi}^{2}$ Greater Green River Basin (fig. 1). The east-west extent of the assessment area is from Rawlins, Wyoming, westerly $60 \mathrm{mi}$; the north-south extent is from about 25 miles (mi) north of I-80 to the Wyoming-Colorado State line. The southwestern boundary of the assessment area was based on cross-section lines where coal bed depths exceeded 4,000 feet (ft).

The area was selected for assessment because there has been no comprehensive resource assessment in this area and abundant, previously unavailable, drill hole data from cooperators and stakeholders became available. Additionally, coal mines located outside of the assessment area that extract coal from the same geologic formations provide an analog for projecting mining conditions and estimating production.

\section{Objectives and Approach}

The principal objective of the USGS Coal Resources and Reserves Assessment Project is to conduct regional-scale coal resource and reserve assessments of major coal beds in the United States. Another important objective is to assist in the update of the U.S. Energy Information Administration (EIA) demonstrated reserve base, the only publicly available, nationwide database system that contains information on the quantities of minable coal conforming to a unified set of criteria (U.S. Energy Information Administration, 1999).

Several components or phases compose a USGS coal assessment project. The most important component is the correlation of all significant coal beds within an assessment area. In this report, the word "significant" in conjunction with the words "coal bed" indicates that the coal bed meets the minimal thickness and areal extent criteria to calculate resources and (or) reserves. A correlated coal bed drill hole database is essential to understand the stratigraphy and coal geology and assess significant resources, as well as to develop economic mining models to estimate the reserve fraction of the assessed recoverable resources. Another component is the economic evaluation of coal resources because it is used to define reserves. The methodology (fig. 3) used in this report is the same as used in previous reports (for example, Luppens and others, 2015).

A third component in the assessment process is the systematic inventory of restrictions to mining to yield the volume of coal that could be potentially recovered.

The objectives of this assessment are as follows

- Build a comprehensive drill-hole database for the assessment area from all available sources and then correlate individual coal beds.

- Develop a comprehensive, multibed geological model for the assessment area (with measures of geological assurance or uncertainty) to support regional resource and reserve estimates.

- Complete an economic evaluation for potential mining that is customized to environmental and technological restrictions for the assessment area.

- Provide the EIA with updated coal availability and recoverability data for the assessment area.

\section{Previous Investigations and Resource Estimates}

In 1825, General W.H. Ashley first recorded fur trappers and traders using coal from the Greater Green River Basin (Roehler, 1992). In August 1852, the first mention of coal in the Rock Springs uplift (fig. 1, west of the assessment area) was made by Howard Stansbury of the U.S. Army Corps of Topographical Engineers (Roehler, 1992) who reported the presence of coal near Evanston, Wyoming, and labeled the area as a coal basin. In 1866, Union Pacific Railroad surveyed the proposed line and explored for nearby coal deposits to provide fuel for the train locomotives (Evans, 1865; Flores and Bader, 1999).

The first geological mapping in the region was conducted by the Hayden survey during 1877 (Hayden, 1879). The first USGS regional survey of coal in the assessment area was in the early 1900s (Ball, 1909; Smith, 1909; Ball and Stebinger, 1910). The first definitive geologic investigation in the basin was undertaken by Schultz (1920), where the Tipton Shale, Cathedral Bluffs, and Laney Members were assigned to the Green River Formation in the northern part of the Washakie Basin. Schultz (1920) also included the first detailed geologic map of the central and eastern part of the Greater Green River Basin that included the Rock Springs uplift and most of the Great Divide, Washakie, and Sand Wash subbasins (fig. 1). Berryhill and others (1950) reported original resources of subbituminous coal under $1,000 \mathrm{ft}$ of overburden in the Washakie and Sand Wash Basins to be about 1.5 billion short tons (BST). Pipiringos and Masursky (1959) reported on uranium-bearing coal areas in the Red Desert area, Sweetwater County, Wyoming. Pipiringos (1961) reported 
that uranium-bearing coal underlies approximately $500 \mathrm{mi}^{2}$ of the central part of the Red Desert assessment area (fig. 4). The following year, Masursky (1962) reported that uranium-bearing coal underlies approximately $300 \mathrm{mi}^{2}$ of the eastern part of the Red Desert assessment area. The areas reported by Pipiringos (1961) and Masursky $(1962,1963)$ are adjacent to each other in the Red Desert assessment area (fig. 4).

Coal resource assessments were conducted in the assessment area in 1977-78 (Mineral Land Evaluation Committee, 1977, 1978). Coal resource occurrence and coal development potential reports for 23 quadrangles covering the Little Snake River coal field part of the assessment area (fig. 5) were published by the USGS (Dames and Moore Company, 1978a-g, 1979a-p). These reports contained estimates of surface and underground original coal resources within the assessment area (table 1). Surface resources were calculated at depths of 0 to $200 \mathrm{ft}$, and underground resources were calculated at depths of 200 to $3,000 \mathrm{ft}$. The total original resources calculated for the 23 quadrangle areas were about 5.8 BST, with 4.7 BST in underground resources and about 1.0 BST in surface resources (table 1).

The USGS conducted drilling in the assessment area in the late 1970s and early 1980s (Barclay and Zimmermann, 1976; Barclay and Shoaff, 1977, 1978; Barclay, 1979a, b, 1980a, b; Hettinger and Brown, 1979). Roehler (1992) provided a detailed discussion of the geologic reports in the Greater Green River Basin. The USGS mapped in detail some of the quadrangles in the assessment area (Sanders, 1974, 1975; Edson and Curtiss, 1976; Edson, 1979; Honey and Hettinger, 1989, 2004; Honey, 1990; Hettinger and Honey, 2005, 2006; C.S.V. Barclay, U.S. Geological Survey, written commun., 2017). A geologic map of Upper Cretaceous and Paleogene strata and the coal stratigraphy of the Fort Union Formation in the Rawlins-Little Snake River area, south-central Wyoming was published in Hettinger and others (2008). Geologic mapping of the Upper Cretaceous units in the area were tabulated and summarized in Haacke and others (2016).

The assessment area is crossed by the Union Pacific Railroad, which parallels I-80; fig. 2). The Railroad Act of 1862 granted alternating sections of land (and mineral rights) to the Union Pacific Railroad in a checkerboard pattern of odd-numbered sections along the right-of-way for every mile of railroad track laid (Flores and Bader, 1999). The Railroad Act was modified in 1864 to grant alternating sections (and mineral rights) to a depth of 20 miles on either side of the railroad for every mile of track laid (Flores and Bader, 1999). This gave the Union Pacific Railroad control of substantial amounts of land underlain by coal in southern Wyoming, including coal in the assessment area that lies beneath the railroad land grant. Rocky Mountain Energy Co., the mineral development subsidiary of the Union Pacific Railroad, conducted exploratory drilling in the land grant areas from 1967 to 1995 . The mineral ownership and the drill hole data for those areas were acquired by Anadarko Land Corporation in 2000 (Donald Ballard, Anadarko Land Corporation, oral commun., 2013). In an agreement with the USGS, Anadarko Land Corporation made available all their drill hole data for use in this assessment and also allowed the USGS to publish those data (Haacke, 2018).

\section{Regional Structural Trends in the Greater Green River Basin}

The Greater Green River Basin is an irregularly shaped intermontane desert basin that is part of the central Rocky Mountain region in southwestern Wyoming (fig. 1; Roehler, 1992). The basin is bounded by the Wind River and Granite Mountains to the north; the Rawlins uplift, Sierra Madre Range, and Park Range to the east; the Axial arch, Uinta Mountains, and Cherokee ridge anticline to the south; and the Wyoming thrust belt to the west. The basin occupies about 15,400 $\mathrm{mi}^{2}$ of Carbon, Fremont, Lincoln, Sweetwater, Sublette, Teton, and Uinta Counties in southwestern Wyoming; Daggett and Summit Counties in northeastern Utah; and Moffat and Routt Counties in northwestern Colorado (fig. 2; Roehler, 1992). The Greater Green River Basin is divided by intrabasinal anticlines into four structural and topographic subbasins (Roehler, 1992). The north-south-trending Rock Springs uplift divides the basin into nearly equal east-west halves; the halves are further divided into subbasins (fig. 1; Roehler, 1992). The Green River and Hoback subbasins are within the western half of the Greater Green River Basin, and the Great Divide, Washakie, and Sand Wash subbasins are within the eastern half of the basin. The southeastern portion of the Great Divide subbasin encompasses the northern portion of the assessment area (fig. 1). Separating the Great Divide and Washakie subbasins is an east-west-trending anticlinal fold known as the Wamsutter arch (fig. 2; Roehler, 1992). To the southwest of the Wamsutter arch, the Washakie subbasin of the Greater Green River Basin (fig. 1) has a surface expression in the shape of a bowl, with the edges of the bowl consisting of high-standing, encircling ridges. From west to east within the assessment area, the ridges are composed of successively older geologic units that dip steeply to the west into the center of the basin. These formations contain coal beds that crop out along the eastern edge of the subbasin within the assessment area. Because these coal beds dip steeply, they only crop out along the eastern margin of the assessment area and have narrow areal extents along their outcrop where they may be surface minable. The southern margin of the subbasin is formed by the east-west trending Cherokee ridge anticline (figs. 1 and 2; Roehler, 1992). The Cherokee ridge anticline separates the Sand Wash and Washakie subbasins.

The structural framework of the Greater Green River Basin formed during the Laramide orogeny that began in the Late Cretaceous. This orogeny was characterized by uplifts of the mountains bordering the basin, flank thrusting at the basin margins, local folding, normal faulting, and rapid subsidence at basin depocenters. The orogeny was not a single event; tectonism occurred intermittently over a 30-million-year period. Following the Laramide orogeny, the last major deformational events (orogenic or tectonic) in this region resulted in the Rock Springs uplift, the Wamsutter arch, and the Cherokee ridge anticline (fig. 2; Roehler, 1992). 
Closely spaced contours along the eastern margin of the Greater Green River Basin mapped at top of the Mesaverde Group (fig. 6) indicate geologic units dipping steeply westerly towards the center of the basin. As the geologic units continue into the basin within the assessment area, the dip flattens. The intrabasinal uplift of the Wamsutter arch and the Rock Springs uplift (fig. 4) were responsible for the arching of the coal beds near the center of the Greater Green River Basin.

\section{Coal Fields}

Wyoming is divided into coal fields on the basis of geographic location and geologic and structural features (Glass, 1978; Ellis and others, 1999a, b). Historical information and data are often discussed as it relates to a particular coal field. Therefore, a short discussion of the location and names of coal fields within the assessment area is presented.

The assessment area is within Wyoming's largest coal-bearing area (Greater Green River Basin), which is divided into six coal fields (fig. 7): La Barge Ridge, Henrys Fork, Rock Springs, Point of Rocks-Black Butte, Great Divide Basin, and Little Snake River (Glass, 1978; Ellis and others, 1999a, b). Adjacent to the eastern margin of the Greater Green River Basin are the Hanna and Kindt Basin coal fields and to the western margin of the basin is the Kemmerer coal field. The assessment area encompasses the Great Divide Basin, Little Snake River, and Rock Springs coal fields.

\section{Generalized Stratigraphy of the Assessment Area}

Coal-bearing strata are present over a 13,000-ft interval of Upper Cretaceous, Paleogene, and lower Neogene rocks within the assessment area. The varied lithologies and geologic features of the coal-bearing stratigraphic units that crop out in the assessment area (figs. 8 and $9 A, B$ ) are the result of changing depositional environments and geologic conditions throughout the Late Cretaceous, Paleogene, and early Neogene. During the Late Cretaceous, the proximity of the assessment area to the Cretaceous seaway resulted in a multitude of depositional environments ranging from fluvial and continental to lower deltaic plain to nearshore marginal marine to marine. These various depositional environments were the result of laterally shifting depositional facies that were responding to fluctuations in sea level, shifting depocenters, and variable basin subsidence. According to depositional interpretations in Hettinger and others (2008) and literature referenced within their report, the exposed formations of the Mesaverde Group represent an overall regressive sequence within the assessment area (from oldest to youngest, the Haystack Mountains, Allen Ridge, and Pine Ridge Sandstone Formations), followed by a sea-level low stand (Pine Ridge Sandstone Formation) and then the beginning of a transgressive sequence (Almond Formation). The transgressive sequence continues upward stratigraphically into the Lewis
Shale. A sea-level high stand is reached in the Lewis Shale and another regressive sequence begins. The regressive sequence continued upward stratigraphically through the shallow marine and shoreline facies (Fox Hills Sandstone), the facies of the shoreline, lower deltaic plain, and interdistributary channels (lower member of Lance Formation), and up into the upper deltaic plain, fluvial, and lacustrine facies (Red Rim Member of the Lance Formation and Fort Union Formation). Continued eastward regression of the Cretaceous seaway at the end of the Late Cretaceous and early Paleocene signaled the onset of the Laramide orogeny in the assessment area.

The continued uplift associated with the Laramide orogeny created an unconformity between the Fort Union Formation and the overlying main body (Red Desert Tongue) of the Wasatch Formation and resulted in the structural partitioning of the Cretaceous foreland basin into a series of intermontane basins (Perry and Flores, 1994). Sediments were shed off the uplifted areas into structurally controlled basins. Several depositional facies were associated with these intermontane basins, including alluvial fans and fluvial channels (Battle Spring Formation), lower delta and shoreline (Wasatch Formation), and lacustrine environments (Green River Formation). The Wasatch Formation coal beds were limited in lateral extent because of a relatively narrow shoreline facies (Roehler, 1988). The intertonguing of the Green River, Wasatch, and Battle Spring Formations is because of lateral facies changes of the depositional environments, which were influenced by episodic variations in sediment input into the basins.

Several studies have described and mapped the geologic units present in the assessment area. During the 1970s and 1980s, the USGS mapped much of the Tertiary Browns Park Formation and Upper Cretaceous Mesaverde Group within the assessment area, which were later compiled in Haacke and others (2016). Hettinger and others (2008) published a geologic map of Upper Cretaceous and Paleogene strata and coal stratigraphy of the Fort Union Formation in the Rawlins-Little Snake River area, south-central Wyoming. The areas mapped and described in these studies are between I-80 and the Colorado-Wyoming State line, an area that covers about 75 percent of the assessment area. Neogene and Paleogene strata within the assessment area include, from youngest to oldest, the Miocene and Oligocene Browns Park Formation; the Eocene Bridger, Green River, and Wasatch Formations; and the Paleocene Fort Union Formation. Strata deposited during the Late Cretaceous include the Lance Formation, the Fox Hills Sandstone, the Lewis Shale, and the Mesaverde Group (Gill and others, 1970).

The youngest deposits in the assessment area are Quaternary unconsolidated clays, silts, and sands and gravels. These surficial deposits are widespread across the assessment area and are preserved as eolian sand dunes, playa lake deposits, landslides, and alluvium and gravel deposits in modern drainages.

The youngest bedrock within the assessment area is the Miocene and Oligocene Browns Park Formation, which consists of an upper sandstone member that generally overlies but locally intertongues with a basal conglomerate member. The Browns Park Formation lies unconformably on older rocks. 
The upper sandstone member was deposited primarily in eolian, fluvial, and floodplain environments, and the basal conglomerate was most likely deposited as alluvial fans derived from the ancestral Sierra Madre and Park Range (Buffler, 2003). The Browns Park Formation attains a thickness of $700 \mathrm{ft}$ north of Savery, Wyoming, $600 \mathrm{ft}$ in a northwest-trending graben near Dixon, Wyo. (fig. 2), and $300 \mathrm{ft}$ in the Poison Basin west of Baggs, Wyo. (Hettinger and others, 2008). Elsewhere within the assessment area, isolated remnants of the Browns Park Formation remain and are less than $180 \mathrm{ft}$ thick.

Underlying the Browns Park Formation is the Bridger Formation, which consists of gray-green claystone and shale with thin interbeds of limestone and cherty algal deposits. The top of the formation is unconformable with the Browns Park Formation, so the thickness of the formation varies from 60 to $250 \mathrm{ft}$ and can be absent locally (Pipiringos, 1961).

The Eocene Green River Formation consists of the Laney Member, Tipton Tongue, and Luman Tongue. Detailed descriptions and correlations of these rocks in the Washakie Basin were made by Roehler $(1973,1988,1989)$ and summarized in descriptions of map units in Hettinger and others (2008). The Laney Member reaches a maximum thickness of $1,050 \mathrm{ft}$ and is primarily composed of brown sandstone, mudrock, oil shale, and limestone deposited in lacustrine, mudflat, and floodplain environments. The Tipton Tongue ranges from 100 to $430 \mathrm{ft}$ thick in outcrops and pinches out near the Colorado-Wyoming State line. It consists of brown to black shale, oil shale, siltstone, and limestone deposited in fresh and saltwater lacustrine, mudflat, and deltaic environments, as well as thick sandstone lenses that were deposited in deltaic environments (Roehler, 1988, 1989; Hettinger and Honey, 2005). The Tipton Tongue is stratigraphically equivalent to the Wilkins Peak Member, which is present near Wamsutter and consists of 30 to $200 \mathrm{ft}$ of shale, oil shale, and algal limestones deposited in saltwater flats and mudflats environments (Hettinger and others, 2008). The Luman Tongue consists of brown and black oil shale deposited in a freshwater lacustrine environment (Roehler, 1989). It is about $320 \mathrm{ft}$ thick in outcrops near Wamsutter and pinches out just north of the Dad arch (Love and Christiansen, 1985; Roehler, 1989).

The upper portion of the Wasatch Formation is stratigraphically and chronologically equivalent to the Green River Formation; intertongues with the Green River Formation represent lateral facies changes in an intermontane depositional environment (Roehler, 1988). The Wasatch Formation also intertongues with the Battle Spring Formation to the north and northeast of the assessment area. These lateral facies changes and intertonguing with the Green River Formation result in the Wasatch Formation being divided into the Cathedral Bluffs Member, the Niland Tongue, and the Red Desert Tongue (main body). The Cathedral Bluffs Member lies between the overlying Laney Member of the Green River Formation and underlying Tipton Tongue of the Green River Formation and consists of reddish-brown and lavender mudstone, gray shale, and greenish-gray and white micaceous sandstone. This member has been observed to be up to $1,450 \mathrm{ft}$ thick along its outcrop, typically forms broad, gentle slopes, and has been interpreted to be a floodplain deposit by Roehler (1989).

The Niland Tongue lies between the overlying Tipton Tongue and underlying Luman Tongue of the Green River Formation and consists of thinly interbedded sandstones and variegated mudstones near the Dad arch. These strata grade laterally northward to gray-green mudstones interbedded with brown or dark-gray carbonaceous shale and tan sandstones. Three minor coal beds, the Bush, Hay, and Luman, were identified in the Niland Tongue and are referred to as the Luman coal zone in this assessment. Because of their limited areal extent, lateral discontinuity, and thinness, resources were not calculated for these coal beds in this assessment (fig. 10). The Niland Tongue reaches a maximum thickness of $40 \mathrm{ft}$ but thins and pinches out just north of the Dad arch. Near Wamsutter, it consists of a 30-ft-thick sandstone and a 5-ft-thick bed of coal (Roehler, 1989). The Niland Tongue was interpreted to be a floodplain and paludal deposit by Roehler (1989).

The main body of the Wasatch Formation (Red Desert Tongue) underlies the Luman Tongue of the Green River Formation, and its base lies unconformably on the Fort Union Formation (Hettinger and others, 2008). The main body is predominantly mudstone with occasional beds of fine-grained sandstone and lenticular, conglomeratic sandstones. It was interpreted to be a floodplain deposit by Roehler (1989). South of the Dad arch, the main body reaches a maximum thickness of $2,100 \mathrm{ft}$ and is red, maroon, green, and light gray. North of the Dad arch, the main body thins to about $1,010 \mathrm{ft}$ and becomes predominantly grayish-white. Near Wamsutter, the lower part of the main body contains several beds of subbituminous coal ranging from 1 to $30 \mathrm{ft}$ thick (Masursky, 1962; Dames and Moore Company, 1978e). Overall, the main body of the Wasatch Formation contains 17 coal beds (fig. 10), which are present north of I-80 in the assessment area but pinch out and are absent south of I-80 to the Colorado-Wyoming State line.

The Paleocene Fort Union Formation lies unconformably beneath the Wasatch Formation and includes, in descending order, the Overland Member, the Blue Gap Member, and the China Butte Member, as defined by Honey and Hettinger (2004). This formation was deposited in fluvial channel, floodplain, lacustrine, and paludal environments (Hettinger and others, 2008).

The Overland Member is about 2,270 ft thick near I-80 and thins southward to about $425 \mathrm{ft}$ thick near the Colorado-Wyoming State line; it includes the Overland coal zone, a middle, fine-grained unit consisting of fine-grained sandstone, siltstone, and mudrock, and a basal, coarse-grained, pebbly sandstone unit (Honey and Hettinger, 2004; Hettinger and others, 2008). The Overland coal zone is about $450 \mathrm{ft}$ thick near I-80 but thins southward and pinches out several miles north of the Dad arch (Hettinger and others, 1991, 2008). It contains six coal beds that range from 1 to $40 \mathrm{ft}$ thick. These collective coal beds are referred to in this report as the Overland coal zone.

The Blue Gap Member consists primarily of mudrock and is about $570 \mathrm{ft}$ thick near the Colorado-Wyoming State line. This member thins northward and pinches out just north of the Dad arch (Honey and Hettinger, 2004; Hettinger and others, 
2008). Where the Blue Gap Member is absent, the Overland Member appears to lie unconformably on the China Butte Member (Honey and Hettinger, 2004).

The China Butte Member is $735 \mathrm{ft}$ thick near the Colorado-Wyoming State line and thickens northward, attaining a maximum thickness of 2,160 ft near I-80. It generally consists of fining-upward units of sandstone, siltstone, claystone, carbonaceous shale, and coal (Hettinger and others, 2008). Sandstone bodies at the base of these units attain thicknesses as great as $220 \mathrm{ft}$ but are generally much thinner. The base of the member is defined by a widespread chert pebble conglomerate that overlies a regional unconformity (Honey and Hettinger, 2004; Hettinger and others, 2008). Nineteen coal beds ranging from 1 to $40 \mathrm{ft}$ thick were identified in the China Butte Member (fig. 10). The Fillmore Ranch coal bed is the thickest and most extensive coal bed in the Fort Union Formation.

The coal beds of the China Butte Member dip variably from $4^{\circ}$ to about $20^{\circ}$ from east to west, flattening out toward the center of the assessment area (fig. 11). The coal beds drape over the intrabasinal uplift of the Wamsutter arch and the Rock Springs uplift, with the depth to the top of the coal beds in the center of the apex of the uplifts being less than at the flanks of the anticlines. All coal beds on the northern side of the Wamsutter arch dip gently $\left(4-6^{\circ}\right)$ to the north from the arch into the Great Divide subbasin.

A regional unconformity delineates the contact of the overlying Paleocene Fort Union Formation and the Upper Cretaceous Lance Formation. The Lance Formation includes the Red Rim Member and an unnamed lower member as described by Honey and Hettinger (2004) and Hettinger and others (2008). The Red Rim Member contains dominant fine- to coarse-grained pebbly sandstone bodies in amalgamated units as much as $200 \mathrm{ft}$ thick. These amalgamated units are separated by 20 - to 100 -ft-thick lenses of mudrock. These rocks are interpreted to have been deposited from fluvial channels and adjacent floodplains. The Red Rim Member is about $370 \mathrm{ft}$ thick near the Colorado-Wyoming State line, although it thickens northward to as much as $900 \mathrm{ft} \mathrm{a}$ few miles south of I-80 (Hettinger and others, 2008).

The lower member of the Lance Formation is about $1,300 \mathrm{ft}$ thick near the Colorado-Wyoming State line and 2,950 ft thick near I-80 (Hettinger and others, 2008). The member is described as being an overall coarsening-upward unit dominated by gray and brown mudrock in its lower part and light-gray, fine-grained sandstone in its upper part. Several lenticular beds of coal, ranging from 1 to $10 \mathrm{ft}$ thick, were also described within the lower $50 \mathrm{ft}$ of the member (fig. 10).

The lower member of the Lance Formation intertongues with the underlying Fox Hills Sandstone. The Fox Hills Sandstone consists of beds that coarsen upward from shale ( 5 to $150 \mathrm{ft}$ thick) to very fine- to medium-grained sandstone ( 5 to $100 \mathrm{ft}$ thick). The thickness of the Fox Hills Sandstone varies from 80 to $500 \mathrm{ft}$ (Hettinger and others, 1991, 2008). The Fox Hills Sandstone intertongues with the underlying Lewis Shale. Where these formations intertongue, their combined thickness reaches a maximum of 1,980 ft (Hettinger and others, 2008, fig. 5).
The Lewis Shale is divided into upper and lower parts. The upper part of the Lewis Shale is generally poorly exposed, forming valleys, in the assessment area. It is composed of olive-gray silty shale with occasional 1 - to 3 -ft-thick, very fine-grained sandstone beds. The sandstone beds are interpreted to be upper marine shelf turbidite flows. The upper part of the Lewis Shale reaches a maximum thickness of $1,170 \mathrm{ft}$ (Hettinger and others, 2008).

The Dad Sandstone Member of the Lewis Shale, where present, intertongues with the upper and lower parts of the Lewis Shale and consists of thick, yellowish-gray to light-brown sandstones, with localized concretions, encased in olive-gray mudstones. It is interpreted to have been deposited in a deep basin turbidite system (Perman, 1990; Witton, 1999; Pyles and Slatt, 2000). The thickness of the member varies greatly, attaining thicknesses of 1,300 $\mathrm{ft}$ in the subsurface, before it thins and pinches out locally. The member contains as much as 400-600 ft of net sandstone in the assessment area and sandstone-dominated intervals attain thicknesses ranging up to $250 \mathrm{ft}$ thick (Law and others, 1989; Hettinger and others, 2008).

The lower part of the Lewis Shale is dark gray, sandy marine shale that is also poorly exposed and forms valleys. The lower part of the Lewis Shale reaches a maximum thickness of about 1,600 ft. It reaches its greatest thickness south of the Dad arch, where the overlying Dad Sandstone thins. The detailed descriptions of the Lewis Shale are summarized from Hettinger and others (2008), based on references cited within that report. The lower part of the Lewis Shale also intertongues with the underlying Almond Formation of the Mesaverde Group.

The oldest rocks evaluated in this assessment area are in the Upper Cretaceous Mesaverde Group, consisting of the Almond Formation, the Pine Ridge Sandstone, the Allen Ridge Formation, and the Haystack Mountains Formation, from youngest to oldest. The Mesaverde Group ranges from 2,700 to $2,900 \mathrm{ft}$ thick in the assessment area and its strata were deposited in interbedded-marine, marginal-marine, and fluvial or deltaic environments (Finn and others, 2005). On the basis of the work of Barclay (1908a, b) and Naftz and Barclay (1991), lithologic descriptions and depositional environments for the Mesaverde Group were summarized by Hettinger and others (2008). Only the Almond and Allen Ridge Formations contains significant coal beds. The remaining formations contain thin and discontinuous beds of coal and are not discussed in this assessment.

The Almond Formation is 450 to $550 \mathrm{ft}$ thick and consists of intertonguing marginal marine and fluvial/deltaic strata. Its upper member is characterized by coarsening-upward units of shale and sandstone interpreted as shoreface deposits. These strata are overlain locally by mudrock and thin beds of coal that accumulated in coastal swamps. Its lower member consists of mudstones, sandstones, and coals that accumulated within distributary channels and interdistributary areas of a lower delta-plain system (Hettinger and others, 2008). Six coal beds in the Almond Formation were assessed for resources; the uppermost bed is in the upper member and the other five beds are in the lower member of the formation (fig. 10). 
The Almond Formation is underlain by the Pine Ridge Sandstone, a 40- to 100-ft-thick fluvial sandstone that is poorly defined in the assessment area. The Pine Ridge Sandstone is interpreted as a continental fluvial deposit, consisting primarily of trough cross-bedded sandstone with minor amounts of carbonaceous siltstones, mudstones, and thin, discontinuous coal beds.

The Allen Ridge Formation is 1,200 to $1,400 \mathrm{ft}$ thick and is informally divided into upper and lower members. The depositional environment for the upper member is marginal marine and consists of thick beds of brown mudstone, very fine-grained, ripple-laminated sandstone, and locally thick, discontinuous coal beds. The upper member reaches a maximum thickness of $220 \mathrm{ft}$.

The depositional environment for the lower member is lower delta plain, with sandstones, siltstones, mudrock, carbonaceous shale, and coal being deposited in fluvial channels and adjacent floodplains. Discontinuous, lenticular, coal beds are generally less than $2 \mathrm{ft}$ thick. Because of the discontinuous nature and limited thickness of the coal beds, they were not assessed for resources. The lower member of the Allen Ridge ranges from 1,000 to $1,200 \mathrm{ft}$ thick.

Conformably underlying the Allen Ridge Formation is the Haystack Mountains Formation. It was deposited in marine and marginal marine environments. The formation consists of thick, alternating units of laterally extensive sandstones and shales. The alternating beds form the prominent cliffs (sandstones) and intervening slopes along the eastern part of the assessment area. The Haystack Mountains Formation reaches a maximum thickness of $950 \mathrm{ft}$.

\section{Previous and Current Coal Mining}

Coal mining in the Rock Springs uplift, west of the assessment area began about 1859 (Evans, 1865; fig. 1). The coal deposits associated with these small (less than 10 acres) mines offered an inducement for development by railroad companies. From 1868 to 1870 , underground coal mines were opened on land granted to the Union Pacific Coal Company in the Greater Green River Basin at Rock Springs, Black Butte, and Point of Rocks (all in the Rock Springs uplift; Flores and Bader, 1999).

By 1870, six coal mines were operating in the Rock Springs uplift of the Greater Green River Basin, which included the Rock Springs, Black Butte, Van Dyk, Blair, Point of Rocks, and Hall Mines. Several coal mines 30 mi east of Rock Springs had production of about 100 train car loads per week (Gardner and Flores, 1989). From 1868 to 1870, coal production from the Rock Springs Mines was 59,417 short tons (ST). Production from the Rock Springs Mines along the Union Pacific Railroad increased to 208,222 ST by 1875 and to 527,811 ST by 1880 (Flores and Bader, 1999). From 1875 to 1895, the tonnage produced from Union Pacific Coal Company mines nearly tripled. Installation of mining machines in the Rock Springs No. 4 Mine increased coal production from 306,150 short tons in 1884 to 943,943 ST in 1892 (Gardner and Flores, 1989).
The introduction of diesel locomotives on railroads during the 1940s and 1950s was an important development for the Union Pacific Coal Company mines in the Rock Springs area (Gardner and Flores, 1989). All but three Union Pacific Coal Company coal mines were closed by the end of 1954 . The last Union Pacific mine near Rock Springs closed in 1962, resulting in the termination of a dependency on coal by the railroad that lasted over 100 years (Flores and Bader, 1999).

In the 1970s, energy suppliers built coal-fired powerplants as a response to Clean Air Act regulations, the need for cheaper energy, and the 1973 Arab oil embargo (Flores and Bader, 1999). Coal in the Rock Springs area was once again on the upswing as modern surface mining methods were introduced, particularly in the Jim Bridger and Black Butte Mines in the 1970s (Flores and Bader, 1999). Since 1974, coal mined at the Jim Bridger Mine has almost exclusively supplied the fuel for the nearby 2,000-megawatt Jim Bridger powerplant (Flores and Bader, 1999). Coal has also been supplied from the adjacent Black Butte Mine.

From the late 1960 s to early 1989 , Kemmerer Coal Company conducted exploration drilling for coal in the Savery area (Tps. 12 and 13 N., Rs. 88 and 89 W.) in Bureau of Land Management (BLM) preference right lease agreement areas (Bureau of Land Management and U.S. Geological Survey, 1983). The coal is within the following BLM coal tracts, from north to south: Atlantic Rim, Cow Creek, and Savery (fig. 12). Although there are several small, abandoned coal mines in the assessment area, no surface or underground mines are currently (2019) in operation.

There are 14 abandoned coal mines (fig. 13) in or near the assessment area (Marcia Murdock, Wyoming Department of Environmental Quality, oral commun., 2014). The specific coal beds mined were determined by comparing the location of each mine to the outcrop of the various coal beds. Two surface mines are in the Overland Member of the Fort Union Formation: the Cherokee Mine (T. 19 N., R. 92 W., sec. 2 and 11) and the Cherokee \#2 Mine (T. 19 N., R. 92 W., sec. 14 and 16). Four underground mines are in the China Butte Member of the Fort Union Formation: the Cut Off Gulch Mine (T. 13 N., R. 91 W., sec. 23), the Pine Bed Mine (T. 21 N., R. 89 W., sec. 26), the Rawlins Prospect Mine (T. 21 N., R. 89 W., sec. 9), and the Red Rim Mine (T. 21 N., R. 89 W., sec. 24). Six mines are in Almond Formation coals; five of these mines are in the Savery area (fig. 11): the Darling Mine (T. 12 N., R. 89 W., sec. 5), the Easom Mine (T. 12 N., R. 88 W., sec. 8), the Pioneer Mine (T. 12 N., R. 89 W., sec. 8), the Savery Mountain and Thomas Mine (T. 12 N., R. 89 W., sec. 5) and an unnamed mine (T. 12 N., R. 89 W., sec. 5). The sixth mine (Dillon Mine) is southwest of Rawlins in T. 21 N., R. 88 W., sec. 36. Two underground mines in the Lance Formation are southwest of Rawlins: the Nebraska Mine (T. 20 N., R. 88 W., sec. 6) and the Fourmile Draw Mine (T. 21 N., R. 88 W., sec. 22). Exact locations for these abandoned mines are not shown figure 13 at the request of the Wyoming Department of Environmental Quality (Marcia Murdock, Wyoming Department of Environmental Quality, oral commun., 2014) to avoid disclosing proprietary information. 


\section{Methodology}

A three-phase methodology was used to calculate coal resources and reserves in the assessment area (fig. 3). This methodology has been used consistently for previously published regional-scale coal assessments (Luppens and others, 2015). The first phase involves data collection and editing. The second phase consists of modeling, including final coal bed correlations, and creation of an inventory of land-use and technical restrictions. The third phase uses the geologic and economic models to calculate coal resources and reserves.

\section{Phase One-Data Collection}

Data pertaining to coal bed geology, including the extent and thickness of coal beds, interburden between beds, partings within beds, structure, and overburden thickness, as well as factors that affect the extraction of coal, coal ownership, coal quality information, coal sales price, and tax information, were gathered during the first phase of the assessment (fig. 3). The data were then verified for location, content relevance, and accuracy.

\section{Drill Hole Data}

A drill hole database is the primary source of information for the assessment. Geological correlations and subsequent models are based on this database. All drill hole data were either digitally imported or manually entered into the StratiFact (GRG Corporation, 1998) drill hole database and geological correlation software.

A total of 4,214 drill holes and measured sections were used to construct the database for this assessment (fig. 14). Drill hole data sources included the USGS National Coal Resources Data System (NCRDS; U.S. Geological Survey, 2016a) and data from Anadarko Land Corporation (Donald Ballard, Anadarko Land Corporation, oral commun., 2013), the Wyoming Oil and Gas Conservation Commission (WOGCC; 2014), and USGS in-house files. NCRDS is the USGS coal database for drill hole and measured section data; the database contained logs for 356 coal drill holes, information on 93 oil and gas wells, and 410 measured sections for this assessment.

In 2000, Anadarko Land Corporation acquired the mineral ownership and the drill hole data for the checkerboard land grant acreage owned by the Union Pacific Railroad. During the 1970s and 1980s, Rocky Mountain Energy had drilled extensively for coal in areas owned by the railroad. A large portion of the assessment area is within the railroad land grant area. Anadarko Land Corporation (Donald Ballard, Anadarko
Land Corporation, oral commun., 2013) authorized the USGS to access data for 1,523 holes drilled for coal exploration and granted the right to publish drill hole locations and lithology descriptions from these data (Haacke, 2018). In addition, the company supplied more than 17,000 scanned drill hole logs, maps, and other relevant data. From these scanned logs, coal data for an additional 268 drill holes were entered into the database by the USGS. Because noncoal lithology was not essential for the coal resource assessment, much of the noncoal lithology was coded as rock. Partings within coal beds and interburden between coal beds were also coded as rock. In total, the NCRDS contributed data for 171 drill holes, and Anadarko Land Corporation, for 1,962 drill holes to the final database. Logs for 936 oil and gas wells were retrieved from the WOGCC's online database of scanned logs of all oil, gas, and coalbed methane wells drilled in Wyoming (Wyoming Oil and Gas Conservation Commission, 2014) and entered into the database used in this assessment (Haacke, 2018). Augmenting the data for oil and gas wells contained in NCRDS resulted in data for 1,101 oil, gas, and coalbed methane wells in the final database. Drill hole data from 458 geophysical and lithologic logs from the USGS Core Research Center (U.S. Geological Survey, 2016b) were included in the database used in this assessment (Haacke, 2018). In addition, 173 drill holes and 410 measured sections from other various sources were entered into the database.

A geographic information system (GIS) project was created in ArcMap (Esri, Inc., 2015) using scanned maps from Anadarko Land Corporation (Donald Ballard, Anadarko Land Corporation, oral commun., 2013), and Dames and Moore (1978a-g, and Dames and Moore 1979a-p). Dames and Moore Company (1979a, b, e, j, 1, g, p) published maps containing 110 measured sections, which had not been entered into the NCRDS; these were subsequently added to the database (Haacke, 2018).

The geospatial coordinate system for the ArcMap project is in Universal Transverse Mercator (UTM) projection (zone 13N) meters using the North American Datum (NAD 83). The drill hole data were derived from multiple sources with multiple coordinate systems. The original NCRDS data were stored in degrees latitude and longitude in the North American Datum of 1927 (NAD 27). The WOGCC data were also in latitude and longitude NAD 27. The Anadarko Land Corporation (Donald Ballard, Anadarko Land Corporation, oral commun., 2013) drill hole data were in stored in Wyoming West Central State Plane coordinates in NAD 27. All drill hole data were converted to a single UTM coordinate system and datum using the U.S. Army Corps of Engineers (2011) Corpscon program. The scanned maps in the GIS project were used, wherever possible, to verify locations of drill holes. 


\section{Coal Quality Data}

Coal quality analyses for individual drill holes were available from Anadarko Land Corporation (Donald Ballard, Anadarko Land Corporation, oral commun., 2013) for many of the coal beds assessed in this study. The average quality for each of the individual coal beds, when available, is presented in combination with the assessments of the specific coal beds. A tabulation of average coal quality and coal rank data as well as the number of analyses available for each coal bed are presented in table 2. Coal quality analyses from individual drill holes are available for 25 coal beds. If coal quality data were available for an individual bed, short proximate analysis data and apparent rank of the coal are presented.

\section{Economic Modeling Data}

Mining component costs are primarily generated from mill equipment costs and mining cost service cost guides published by InfoMine, Inc. (2015a, b). InfoMine cost guides provide detailed information of the costs of mining and milling equipment, electrical power, natural gas, labor, suppliers, transportation, and taxes and are particularly suited for estimating costs associated with mine investment and operation. Heavy construction cost data published in Hale (2016) provide detailed information on construction crews, hourly and daily output, material, equipment, and base labor costs plus allowances for overhead and profit, as well as the rates for construction, demolition, earthwork, materials and their handling, and a wide variety of related topics. The cost guide of Hale (2016) is valuable for estimating mine setup, facility teardown, and contract services.

All contractual work, including site preparation, construction of facilities, reclamation, and decommissioning, is detailed in Hale (2016). Mining machinery, electricity rates, natural gas rates, labor rates, supplies, and taxes are detailed in InfoMine, Inc. (2015a, b) and Hale (2016). Federal, State, and local taxes are calculated as a composite percentage that falls within a range of 40 to 60 percent of the calculated net profit.

Mining and associated costs are managed in accordance with Association for the Advancement of Cost Engineering International Recommended Practice 17R-97 (Association for the Advancement of Cost Engineering, 2016) and Internal Revenue Service (2015a-c) guidelines for asset classification and depreciation.

InfoMine, Inc. (2015a, b) and Hale (2016) also provide historical cost indices. InfoMine, Inc. (2015a, b) historical costs are based on Bureau of Labor Statistics reports, and historical costs in Hale (2016) are based on industry surveys by the Engineering News-Record. Hale (2016) also provides cost adjustment indices by location for cities and States. A number of costs incorporated in the USGS models are not covered by either set of costing guides. The treatment of these costs is in accordance with recommended cost estimation practices in International Recommended Practice 17R-97 (Association for the Advancement of Cost Engineering, 2016) and specifications for Federal taxable expense characterization (Internal Revenue Service, 2015a-c).

\section{Phase Two-Geologic and GIS Modeling}

Phase two involved the correlation of individual coal beds; creating integrated, multibed models; and collecting and analyzing land-use and technical restrictions to apply to the mining models (fig. 3). Establishing consistent regional coal bed stratigraphy and correlations in the assessment area was essential for mapping and assessing individual coal beds.

The primary objective in resource planning is to determine the amount of recoverable coal resources and reserves. This process is accomplished by first calculating the original resources and then the remaining resources. For this assessment, there was no reported production of previously mined coal; therefore, the remaining resources are equal to the original resources. The final step is to determine the recoverable coal resources by subtracting the coal resources lost because of pit losses, pillars and barriers, or from clean coal processing procedures from the available resources. In this assessment, pit losses and coal left to pillars and barriers are not determined, and coal produced in this region is typically not processed through cleaning plants, so available resource and recoverable resource values are identical. Since reserves are calculated from the recoverable coal resources, recoverable resources are the values reported in this assessment. The criteria for determining land-use and technical restrictions are explained later in the text. The portion of the recoverable coal resources where the unit value of the extracted product is greater than the unit cost to extract it are reserves.

\section{Coal Bed Correlations}

In step one of phase two, all drill hole data were entered into the StratiFact database software program (GRG Corporation, 1998). The graphical interface in the StratiFact program was a critical tool for managing the interpretation of the large amounts of data. Both linear and circular cross sections were viewed in order to correlate coal beds across the assessment area. Circular cross sections, in which the first and last hole are the same, were particularly useful to confirm correlations, especially in areas with multiple coal beds or without definitive marker beds. 


\section{Coal Bed Modeling}

In step two of phase two, digital coal bed models were created (fig. 3). The integrated multibed modeling software program PC/Cores (Mentor Consultants, 2005) was used to produce grids for all assessed coal beds. PC/Cores was used as a two-step process to generate coal thickness grids that consider drill holes where a modeled coal bed may be missing because of nondepositional or postdepositional erosion. The first step is the generation of a structure contour grid for the coal bed. The second step is the generation of a thickness grid for the coal bed. In generating the thickness grids, PC/Cores was used to identify on the basis of the structure contour grid drill holes that penetrate through the coal bed horizon but lack a thickness value. PC/Cores was then used to search the data around the drill holes that lack thickness values to determine the closest drill holes where the modeled coal bed is present. The thickness values from those closest drill holes were applied to the thickness grid as negative values for the drill holes without thickness values. This process is known as "negative pinching" and results in the thickness values in the grid pinching out to zero halfway between the nearest positive thickness data point and the actual zero value location. Therefore, use of the negative pinching function provides a slightly more conservative projection of coal bed areal extent, particularly where data points are more widely spaced. This effect can be seen in many of the coal thickness and depth to coal maps where there are small, isolated areas along the outcrop surrounded by areas with no data. The areas between data points appear white in the resulting maps, indicating negative pinching between data points. Therefore, the coal bed outcrop lines in some of the figures in this report may not coincide with the coal bed outcrop lines in the report by Hettinger and others (2008).

Another feature of the $\mathrm{PC} /$ Cores program is the ability to recognize where a coal bed may be absent because of insufficient lithologic data or drill-hole depth. Insufficient lithologic data are often encountered in oil and gas wells not logged at the top where there is surface casing. This interval may be described in the drill-hole log as "no data" or "not logged." $\mathrm{PC} /$ Cores will "pass through" these drill holes when generating a coal thickness grid without assigning a thickness value using "negative pinching." This pass-through feature assists in reducing the generation of false zero thickness values.

Along with the coal bed structure and thickness grids, $\mathrm{PC} / \mathrm{Cores}$ was used to generate grids for parting thickness and depth to the top of the coal bed. USGS coal resource assessments do not have a standard grid-cell size used for all GIS analyses. For this GIS assessment, a grid-cell size of 60 meters (m; about $200 \mathrm{ft}$ ) was chosen. A final set of these grids for each of the 33 coal beds was converted in the PC/Cores program to a generic American Standard Code for Information Interchange (ASCII) grid format in order to be used in ArcMap. ArcMap software was used to generate a gridded spatial distribution of coal resources by subtracting amounts of various restrictions to mining (for example, towns and Federal interstate highways) in order to calculate the amount of available coal. ArcMap was also used to project digital coverages, shapefiles, and grids to the assessment area's base-map projection. The projection system used for the GIS analysis was UTM (zone 13N), NAD 83 in meters.

Resource reliability classifications (measured, indicated, inferred, and hypothetical), based on data point spacing density, were generated from grids, based on recoverable coal resources. Depth of cover grids for individual coal beds were generated, based on the following criteria:

- 0 to $300 \mathrm{ft}$; these are resources that could be extracted using surface mining methods.

- 300-3,000 ft; these are resources that could be extracted using underground mining methods.

Next, a series of exclusion polygons were created that categorized the assessment area, with each exclusion polygon representing one specific theme. These themes consisted of land-use restrictions, technical restrictions, and coal ownership (Federal, state, or private). Individual exclusion polygons of the land-use and technical restrictions were then combined into one composite exclusion polygon, which was then overlaid on the thickness maps showing the areal extent of each individual coal bed. This methodology was used to determine the available and recoverable coal resources within the assessment area on a bed-by-bed basis according to all the categories.

\section{Coal Bed Assessment}

At least 55 named coal beds were identified through correlations in the assessment area; however, only $33 \mathrm{had}$ sufficient areal extent and thickness to calculate meaningful resource numbers. The primary criteria used in this study to assess coal beds was an areal extent of at least $2 \mathrm{mi}^{2}$ with an average thickness of $3 \mathrm{ft}$ or greater.

The sequence for surface mining starts with the youngest beds at the ground surface; therefore, assessed coal beds are discussed from youngest to oldest. The zones from youngest to oldest are the Luman, Wasatch, Overland, China Butte, Lance, Almond, and Allen Ridge coal zones. Of these seven coal zones, only four contained significant coal beds (fig. 15) that were assessed for resources: Wasatch, Overland, China Butte, and Almond. Based on areal extent, number of drill holes, and the relatively thin average thickness of their coal beds, the Luman, Lance, and Allen Ridge coal zones did not warrant resource estimates. Maximum and average bed thicknesses shown on figure 10 were based on recoverable resources.

The term "coal zone" in this report is used to include a group of coal beds within a particular formation or member of a formation; for example, the Wasatch coal zone is a group of coal beds within the main body of the Wasatch Formation, the Overland coal zone is within the Overland Member of the Fort Union Formation, the China Butte coal zone is within 
the China Butte Member of the Fort Union Formation, and the Almond coal zone is within the Almond Formation. Information on the drill hole database and the GIS layers that were created using ArcMap (Esri, Inc., 2015) that can be used to show the assessment area boundary in map view along with other pertinent data layers can be found in Kinney and others (2018).

The lateral continuity for the Paleogene Wasatch, Overland, and China Butte coal zones is pervasive throughout cross section $A-A^{\prime}$ in the northwestern part of the assessment area (fig. 16). The Wasatch and Overland coal zones are separated by less than 1,000 ft, whereas the interburden between the Overland and China Butte coal zones is 1,300 ft or greater. The interburden thickness between the China Butte coal zone and the Lance coal zone ranges from about 1,500 ft near Baggs to about 4,000 ft near I-80 (Hettinger and others, 1991).

\section{Wasatch Formation}

The Wasatch Formation is divided into three stratigraphically distinct units: the Cathedral Bluffs Member, the Niland Tongue, and the Red Desert Tongue (main body). The Red Desert Tongue will be referred to in this report as the "main body." These units are separated by clay-rich tongues of the Green River Formation. The Niland Tongue and main body are coal-bearing units. Within the assessment area, 776 coal test holes and 37 oil and gas wells provided data for correlations and geologic modeling of the Wasatch Formation.

Coal beds within the Niland Tongue form the Luman coal zone. It is the youngest coal zone described in this assessment. The Luman coal zone includes the Bush, Hay, and Luman coal beds.

Coal beds within the Wasatch main body form the Wasatch coal zone. The Wasatch coal zone contains the Battle (with an upper split), Monument (with upper and lower splits), Sourdough (with upper and lower splits), Larsen, Hadsell, Creston (with upper and lower splits), Latham (with upper and lower splits), and two unnamed local coal beds (fig. 16; Pipiringos, 1961). The Wasatch coal zone is in the lower part of the main body and is about 1,300 $\mathrm{ft}$ thick. Most of the coal beds with considerable thickness and lateral extent (Monument, Sourdough, Creston, and Latham beds) are concentrated in the bottom $500 \mathrm{ft}$ of the coal zone.

The coal beds in the Luman and Wasatch coal zones are on the northern side of the Wamsutter arch in the Great Divide Basin in an area known as the Red Desert. They cover an area of about $700 \mathrm{mi}^{2}$ mostly north of I-80, from Wamsutter to Creston Junction. There is a very prominent depocenter with a northwest-southeast trending axis, with the thickest coal to the southeast and decreasing thickness along the axis to the northwest. The maximum composite thickness is about $85 \mathrm{ft}$ (fig. 17). In general, the Wasatch Formation coals crop out to the south and pinch out to the east, west, and north. Structurally, there is a very gentle dip of less than 1 degree to the north where the Wasatch coal zone is present within the assessment area.
The stratigraphy and coal correlations of Masursky and Pipiringos (1953), Pipiringos (1961), and Masursky (1962), were based on detailed mapping of the coal beds, measured sections, and 71 USGS core holes. The measured sections were plotted on the maps and drafted in cross sections of their reports.

However, they did not have elevation control and the plotted measured sections also lacked detailed lithologic descriptions and thickness values. Therefore, the measured sections were not used for modeling the coal beds in the assessment.

The Wasatch Formation coal bed names used in this report are derived primarily from Pipiringos (1961) and Masursky (1962). The coal beds were named after prominent features near outcrops. For example, the Latham and Creston beds are named after small stations of the Union Pacific Railroad, and the Hadsell and Larsen are named for nearby ranches. Pipiringos (1961) and Masursky (1962) named beds as coal zones, such as the Latham coal zone. Then individual coals in the zones were numbered from oldest to youngest, such as La-1, La-2, La-3, and La-4. This report, based on substantially greater amounts of data, uses a somewhat modified naming system. The main names for all beds were retained for the dominant coal in the zone and splits from the main bed were named with "Upper" and "Lower" prefixes, such as Upper Latham, Latham, and Lower Latham. Drilling in the 1970s and 1980s by Rocky Mountain Energy and the USGS used the same naming system for the major beds. Two coal beds below the Latham were unnamed in the literature. For convenience in this report, they are named as the unnamed \#1 (upper bed) and the unnamed \#2 (lower bed) coal beds.

The Wasatch coal beds are mostly within the Union Pacific Railroad land grant area with the exception of a very small area to the north (fig. 17). In the 1970s, Rocky Mountain Energy extensively drilled the area within the railroad's land grant. All Rocky Mountain Energy drill hole data were available and critical in developing the coal assessment.

\section{Luman Coal Zone (Niland Tongue)}

The youngest Eocene-age coal beds in the assessment area are within the Luman coal zone of the Niland Tongue (fig. 10). The Niland Tongue was observed to be approximately $40 \mathrm{ft}$ thick in outcrops (Roehler, 1988). Three coal beds were correlated within the Niland Tongue of the Wasatch Formation: Bush, Hay, and Luman (fig. 10). Because of the limited drill hole data and average thickness less than $3 \mathrm{ft}$, these beds were not assessed for resources.

\section{Bush Coal Bed}

The Bush coal bed is the youngest coal bed in the Luman coal zone and was identified in only two drill holes in T. $24 \mathrm{~N}$., R. 95 W., sec. 10 and 16. Pipiringos (1961) traced the coal outcrop for 12 miles farther west. The maximum thickness of the coal bed in the drill holes was $1.2 \mathrm{ft}$ drill. 


\section{Hay Coal Bed}

The Hay coal bed was observed in only four drill holes in T. 24 N., R. 95 W., sect. 2, 10, 16, and 21. Pipiringos (1961) traced the coal outcrop for 14 miles farther west. The maximum thickness of the coal bed in the drill holes was $2.5 \mathrm{ft}$ drill.

\section{Luman Coal Bed}

The Luman coal bed was observed in only nine drill holes along a transect from T. 24 N., R. 95 W., sec. 2 to T. 24 N., R. 96 W., sec. 22. The coal outcrop was traced for 8 miles to the west (Pipiringos, 1961). The maximum coal thickness in the drill holes was $4.4 \mathrm{ft}$ and is $5 \mathrm{ft}$ in 15 measured sections. Pipiringos (1961) used outcrop data and limited drill hole data and calculated a resource of 54 million short tons of measured and indicated coal in two beds in his "Luman coal zone."

\section{Wasatch Coal Zone (Main Body)}

There are 17 coal beds in Wasatch coal zone in the main body of the Wasatch Formation (figs. 10 and 17). Only nine of those beds had sufficient thickness and areal extent to warrant calculation of resources: Monument, Upper Sourdough, Lower Sourdough, Larsen, Creston, Lower Creston, Upper Latham, Latham, and unnamed coal bed \#2. Original resources for the Wasatch coal zone in the main body of the Wasatch Formation total approximately $6.8 \mathrm{BST}$. Recoverable resources total approximately $2.6 \mathrm{BST}$, with $1.16 \mathrm{BST}$ being extractable through surface mining methods (Figures 3 and 5).

Cross section $A-A^{\prime}$ (fig. 18) shows a west-east profile of coal beds in the northern part of the Wasatch coal zone and demonstrates the lateral continuity of these beds in the assessment area. This cross section illustrates the interburden thickness between coal beds and shows the thick Monument coal in comparison to the other Wasatch coal beds in this area. Cross section $B-B^{\prime}$ (fig. 19) shows a north-south profile of coal beds through the Wasatch coal zone and illustrates how the coal beds crop out along the southern part of the coal zone and dip northward into the Great Divide Basin. The cross section also illustrates the relative thickness of the Monument and Creston coal beds in relation to the other beds within the zone. Cross section $C-C^{\prime}$ (fig. 20) shows a southwest-northeast profile in the southern part of the Wasatch coal zone and illustrates how coal beds are thickest in the center and thin to the southwest and northeast.

\section{Upper Battle and Battle Coal Beds}

The Upper Battle coal bed is the youngest coal bed in the Wasatch coal zone and was identified in 10 drill holes with a maximum thickness of $3 \mathrm{ft}$ and averaging $1.9 \mathrm{ft}$. The Battle coal bed was identified in 37 drill holes with a maximum thickness of $11 \mathrm{ft}$ and an average of $3 \mathrm{ft}$ (fig. 10). Neither coal bed was assessed for resources because of limited drill hole data and limited (less than $[<] 2.0 \mathrm{mi}^{2}$ ) areal extent. The interburden thickness between the bottom of the Battle coal bed and the top of the Upper Monument coal bed is about $70 \mathrm{ft}$ (fig. 17).

\section{Upper Monument, Monument, and Lower Monument Coal Beds}

The Upper Monument coal bed splits off the top to the Monument coal bed. Identified in 51 drill holes, the Upper Monument coal bed has a maximum thickness of $9 \mathrm{ft}$ and an average of $3.2 \mathrm{ft}$ (fig. 10). The areal extent of this bed was less than $2 \mathrm{mi}^{2}$ and was not assessed for resources.

Identified in 165 drill holes, the Monument coal bed has a maximum thickness of $19.5 \mathrm{ft}$ and an average thickness of $8.9 \mathrm{ft}$ (figs. 10 and 21). The bed averages more than $10 \mathrm{ft}$ thick where it crops out along the southeastern extent of the zone and is about $15 \mathrm{ft}$ thick where depths of cover are less than $150 \mathrm{ft}$. In areas where the bed is $5 \mathrm{ft}$ thick or greater, it has an areal extent of about $83 \mathrm{mi}^{2}$; however, where the bed is $10 \mathrm{ft}$ thick or greater, the areal extent decreases to about $24 \mathrm{mi}^{2}$. The depth to the top of the bed ranges from the outcrop along its southeastern extent to about $530 \mathrm{ft}$ near the center of the basin (fig. 22). Recoverable resources were calculated to be 531 MST, with 460 MST that may be extracted through surface mining methods (fig. 10; tables 3 and 4).

The Lower Monument coal bed splits off the bottom of the Monument coal bed. The Lower Monument coal bed was identified in 32 drill holes, with a maximum thickness of $4 \mathrm{ft}$ and an average thickness of $1.6 \mathrm{ft}$. This bed lacked the areal extent and thickness to be assessed for resources.

Coal quality data were available from 26 drill holes for the Monument coal bed (table 2). Average as-received moisture was 22.71 percent, average as-received ash was 12.96 percent, average as-received total sulfur was 2.38 percent, and average as-received specific energy was 8,252 British thermal units per pound $(\mathrm{Btu} / \mathrm{lb})$. The apparent rank of the Monument coal is subbituminous B. The interburden thickness between the bottom of the lower Monument coal bed and the top of the Upper Sourdough coal bed is about $50 \mathrm{ft}$ (fig. 17). 


\section{Upper and Lower Sourdough Coal Beds}

The Upper Sourdough coal bed is a split of the Lower Sourdough coal bed. Where they split, the Lower Sourdough coal bed is the more substantial in terms of thickness and extent. Generally, the interburden thickness between these two beds is about $25 \mathrm{ft}$ (fig. 17). The Lower Sourdough coal bed crops out in T. 22 N., R. $94 \mathrm{~W}$, sec. 23.

Correlated in 124 drill holes, the Upper Sourdough coal bed has a maximum thickness of $9 \mathrm{ft}$ and an average thickness of $3.8 \mathrm{ft}$ (figs. 10 and 23). The bed is relatively thin where it crops out and is less than $5 \mathrm{ft}$ thick throughout most of its areal extent. The depth to the top of the bed ranges from the outcrop along its southeastern extent to about $585 \mathrm{ft}$ near the center of the basin (fig. 24). Recoverable resources for the Upper Sourdough coal bed were calculated to be 1 MST (fig. 10; tables 3 and 4).

Identified in 226 drill holes, the Lower Sourdough coal bed has a maximum thickness of $16 \mathrm{ft}$, with an average thickness of $6.6 \mathrm{ft}$ (figs. 10 and 25). In areas where the Upper Sourdough and Lower Sourdough coal beds form one bed, the overall bed thickness is greater than $5 \mathrm{ft}$, and the areal extent is about $54 \mathrm{mi}^{2}$; however, where the overall bed thickness is greater than $10 \mathrm{ft}$, the areal extent decreases to about $3 \mathrm{mi}^{2}$. The depth to the top of the coal bed ranges from the outcrop along its southeastern extent to about $375 \mathrm{ft}$ near the center of the basin (fig. 26). Recoverable resources for the Lower Sourdough coal bed were calculated to be $180 \mathrm{MST}$, with $115 \mathrm{MST}$ that may be extracted through surface mining methods (fig. 10; tables 3 and 4).

Coal quality data were available from 10 drill holes for the Lower Sourdough coal bed (table 2). Average as-received moisture was 20.95 percent, average as-received ash was 15.58 percent, average as-received total sulfur was 2.49 percent, and average as-received specific energy was $8,176 \mathrm{Btu} / \mathrm{lb}$. The apparent rank of the Lower Sourdough coal bed is subbituminous B. The interburden thickness between the bottom of the Lower Sourdough coal bed and the Larsen coal bed is about $50 \mathrm{ft}$ (fig. 17).

\section{Larsen Coal Bed}

The Larsen coal bed was identified in 192 drill holes and has an areal extent of about $59 \mathrm{mi}^{2}$. It has a maximum thickness of $8 \mathrm{ft}$ and an average thickness of $4.1 \mathrm{ft}$ (figs. 10 and 27). The Larsen coal bed has an areal extent of about $3 \mathrm{mi}^{2}$ of coal with thickness greater than $5 \mathrm{ft}$. The depth to the top of the bed ranges from the outcrop along its southeastern extent to about $445 \mathrm{ft}$ near the center of the basin (fig. 28). Recoverable resources for the Larsen coal bed were calculated to be $12 \mathrm{MST}$ (fig. 10; tables 3 and 4). The interburden thickness between the bottom of the Larsen coal bed and the top of the Hadsell bed is about $80 \mathrm{ft}$ (fig. 17).

\section{Hadsell Coal Bed}

The Hadsell coal bed was identified in 289 drill holes and has a maximum thickness of $9.5 \mathrm{ft}$, with an average thickness of $2.7 \mathrm{ft}$ (fig. 10). This bed is about $85 \mathrm{ft}$ below the Larsen coal bed. Because the bed averages less than $3 \mathrm{ft}$ thick, it was not assessed for resources. The interburden thickness between the bottom of the Hadsell coal bed and the top of the Upper Creston coal bed is about $50 \mathrm{ft}$ (fig. 17).

\section{Upper Creston, Creston, and Lower Creston Coal Beds}

The Upper Creston coal bed is a split of the Creston bed (fig. 17). Identified in 104 drill holes, it has a maximum thickness of $5.7 \mathrm{ft}$ and an average thickness of $2.4 \mathrm{ft}$ (fig. 10). This bed was not assessed for resources because of its limited areal extent $\left(<2.0 \mathrm{mi}^{2}\right)$. The interburden between the bottom of the Upper Creston bed and the top of the Creston bed ranges from 1 to $10 \mathrm{ft}$ (fig. 17).

The Creston coal bed is the thickest coal bed in the Wasatch coal zone. Identified in 409 drill holes, the bed has a maximum thickness of $42 \mathrm{ft}$ and an average thickness of $11.2 \mathrm{ft}$ (figs. 10 and 29). The bed has an areal extent of about $164 \mathrm{mi}^{2}$ where the coal is greater than $5 \mathrm{ft}$ thick, about $83 \mathrm{mi}^{2}$ where the coal is greater than $10 \mathrm{ft}$ thick, and about $46 \mathrm{mi}^{2}$ where the coal is greater than $15 \mathrm{ft}$ thick. The bed crops out along its southeastern extent with thicknesses in excess of $15 \mathrm{ft}$ along I-80 (fig. 29). The depth to the top of the coal bed ranges from the outcrop along the southeastern extent to more than $560 \mathrm{ft}$ near the center of the basin (fig. 30). Recoverable resources for the Creston bed were calculated to be 907 MST, with 490 MST that may be extracted through surface mining methods (fig. 10; tables 3 and 4). The interburden thickness between the bottom of the Creston coal bed and top of the Lower Creston coal bed ranges from 1 to $20 \mathrm{ft}$ (fig. 17).

The Lower Creston coal bed is another split of the Creston bed and is present to the west, north, and east. Identified in 186 drill holes, this bed has a maximum thickness of $12 \mathrm{ft}$ and an average thickness of $4.7 \mathrm{ft}$ (figs. 10 and 31). Within the assessment area, the bed has an areal extent of about $10 \mathrm{mi}^{2}$ of coal greater than $5 \mathrm{ft}$ thick. The depth to the top of the coal bed ranges from the outcrop along its southeastern extent to about $560 \mathrm{ft}$ near the center of the basin (fig. 32). Recoverable resources for the Lower Creston bed were calculated to be 14 MST (fig. 10; tables 3 through 5).

Coal quality data were available from 59 drill holes for the Creston coal bed (table 2). Average as-received moisture was 21.43 percent, average as-received ash was 19.12 percent, average as-received total sulfur was 2.52 percent, and average as-received specific energy was 7,501 Btu/lb. The apparent rank of the Creston coal is subbituminous $\mathrm{C}$. The interburden between the bottom of the Lower Creston bed and the top of the Upper Latham bed is about $50 \mathrm{ft}$ (fig. 17). 


\section{Upper Latham, Latham, and Lower Latham Coal Beds}

The Upper Latham coal bed was identified in 186 drill holes and has a maximum thickness of $13.5 \mathrm{ft}$, with an average thickness of $4.5 \mathrm{ft}$ (figs. 10 and 33). The bed has an areal extent of about $6 \mathrm{mi}^{2}$ where the coal is greater than $5 \mathrm{ft}$ thick. The depth to the top of the bed ranges from the outcrop along its eastern extent to about $540 \mathrm{ft}$ in the basin (fig. 34). Recoverable resources for the Upper Latham bed were calculated to be 13 MST (fig. 10; tables 3 and 4).

The Latham coal bed has been identified in 294 drill holes. It has a maximum thickness of $26 \mathrm{ft}$ with an average thickness of $10.4 \mathrm{ft}$ (figs. 10 and 35). The bed has an areal extent of about $151 \mathrm{mi}^{2}$ where the coal is greater than $5 \mathrm{ft}$ thick, about $58 \mathrm{mi}^{2}$ where the coal is greater than $10 \mathrm{ft}$ thick, and about $26 \mathrm{mi}^{2}$ where the coal is greater than $15 \mathrm{ft}$ thick. The depth to the top of the bed ranges from the outcrop along its southeastern extent to about $690 \mathrm{ft}$ in the basin (fig. 36). Recoverable resources for the Latham coal bed were calculated to be 561 MST, with 67 MST that may be extracted through surface mining methods (fig. 10; tables 3 and 4). The interburden thickness between the bottom of the Latham coal bed and the top of the Lower Latham coal bed is about $20 \mathrm{ft}$ (fig. 17).

The Lower Latham coal bed splits off from the Latham bed. It was identified in 47 drill holes and has a maximum thickness of $9 \mathrm{ft}$ and an average thickness of $5.7 \mathrm{ft}$ (fig. 10). This bed was not assessed for resources because of limited areal extent $\left(<2 \mathrm{mi}^{2}\right)$.

Coal quality data were available from 44 drill holes for the Latham coal bed (table 2). Average as-received moisture was 21.23 percent, average as-received ash was 19.42 percent, average as-received total sulfur was 2.12 percent, and average as-received specific energy was $7,403 \mathrm{Btu} / \mathrm{lb}$. The apparent rank of the Latham coal is subbituminous $\mathrm{C}$. The interburden between the bottom of the Lower Latham bed and the top of the unnamed 1 bed is about $20 \mathrm{ft}$ (fig. 17).

\section{Unnamed \#1 and Unnamed \#2 Coal Beds}

Two minor coal beds below the lower Latham coal bed have not been previously noted in any publications. The unnamed \#1 coal bed was identified in 46 drill holes and has a maximum thickness of $7.6 \mathrm{ft}$, with an average thickness of $3.1 \mathrm{ft}$ (fig. 10). This bed was not assessed for resources because of limited areal extent and thickness. The interburden thickness between the bottom of the unnamed 1 coal bed and the top of the unnamed 2 coal bed is about $10 \mathrm{ft}$ (fig. 17).

The unnamed \#2 coal bed is the lowest bed in the Wasatch coal zone. It was interpreted from 24 drill holes and has a maximum thickness of $17 \mathrm{ft}$, with an average thickness of $5.7 \mathrm{ft}$ (figs. 10 and 37). The depth to the top of the bed ranges from the outcrop along its eastern extent to more than $700 \mathrm{ft}$ in the center of the basin (fig. 38). Recoverable resources for the unnamed \#2 bed were calculated to be $418 \mathrm{MST}$, all of which were classified as underground recoverable resources (fig. 10; tables 3 and 4).

\section{Fort Union Formation}

The Fort Union Formation is divided into three members. From youngest to oldest, they are the Overland Member, Blue Gap Member, and China Butte Member. Both the Overland and China Butte Members contain coal zones. The coal zones bear the same name as their respective members.

\section{Overland Coal Zone}

The Overland coal zone is approximately $600 \mathrm{ft}$ below the lowest Wasatch coal bed. The Overland coal zone has been previously referred to as the Cherokee coal zone by Sanders $(1974,1975)$ and Hettinger and others $(1991,2008)$. The Overland coal zone is roughly centered near the town of Wamsutter and extends north and south of I-80 (fig. 39). The coal zone covers an area of about 1,000 $\mathrm{mi}^{2}$ of the northern part of the assessment area and partially lies beneath the Wasatch coal zone (fig. 10). Coal beds within the zone crop out southeast of the town of Wamsutter and drape over the Wamsutter arch to the north (fig. 2). The beds dip northerly into the Great Divide subbasin to depths greater than 2,000 ft and southwesterly into the Washakie subbasin to depths of more than 3,500 ft. Bed names used in the correlations were from Hettinger and others (2008). Data used for the Overland coal zone were derived from 13 measured sections, 231 coalbed methane wells, 377 coal test holes, and 432 oil and gas wells.

The maximum composite thickness of all beds in the zone is about $70 \mathrm{ft}$ (fig. 39). The thickest coal occurs southeast of Wamsutter where the coal crops out, as shown by Sanders $(1974,1975)$ and Hettinger and others (2008). The coal zone from the top of the uppermost High Point coal bed to the base of the lowermost Horse Butte coal bed is about $400 \mathrm{ft}$ thick (fig. 40). These beds lie mostly within the Union Pacific Railroad land grant. The outcrop and near-surface areas of this formation are referred to as the Cherokee and North Horse Butte competitive Federal coal lease areas (fig. 12; Bureau of Land Management and U.S. Geological Survey, 1983).

There are six named coal beds in the Overland coal zone (fig. 40). Only five of those have sufficient thickness and areal extent to warrant calculation of resources: Upper Cherokee, Cherokee, Lower Cherokee, Cow Butte, and Horse Butte. Thickness and overburden figures for these assessed coal beds are provided in this report. The thickness, depth to coal, and reliability coverages for all coal beds in the Overland coal zone are detailed in Kinney and others (2018). Original resources for the Overland Member of the Fort Union Formation were calculated to be about 23.0 BST. After coal losses because of land-use and technical restrictions were subtracted, recoverable resources totaled approximately 8.4 BST. Recoverable coal resources that may be extracted using surface mining methods were $535 \mathrm{MST}$, with the remaining $7.88 \mathrm{BST}$ having to be extracted using underground mining methods (tables 3 through 5). 
Lateral continuity and structure for coal beds in the Overland coal zone are shown in cross sections $D-D^{\prime}$ and $E-E^{\prime}$ (figs. 41 and 42). Cross section $D-D^{\prime}$ (fig. 41) shows a northwest-southeast profile of coal beds through the center of the formation and illustrates both the lateral continuity that these coal beds maintain throughout the assessment area and the relative interburden thickness between the beds. The cross section also shows how the beds crop out along the southeastern part of the assessment area and dip steeply to the northeast towards the center of the Great Divide Basin. Cross section $E-E^{\prime}$ (fig. 42) is a southwest-northeast profile showing the beds draping over the Wamsutter arch. Also evident in this cross section is the lateral continuity of the Cherokee, Lower Cherokee, and Horse Butte coal beds from southwest to northeast. Cross section $F-F^{\prime}$ (fig. 43) shows five individual benches of the Cherokee bed and how they split away from the central, thick portion of the coal bed to form the Upper and Lower Cherokee coal beds.

\section{High Point Coal Bed}

Coal beds correlating to the High Point coal bed were identified in 29 drill holes. These beds have a maximum thickness of $8.5 \mathrm{ft}$ and an average thickness of $3.6 \mathrm{ft}$ (fig. 10). There are at least two coal beds in this part of the stratigraphic section. These coal beds overlie the thickest portion of the Cherokee coal interval and may be rider coals of the Cherokee coal bed. The lateral continuity of these beds is erratic, making definitive correlations in this part of the stratigraphic section difficult. These beds were not assessed for resources because of the limited drill hole data and limited areal extent. The interburden thickness between the bottom of the High Point beds and the top of the upper Cherokee bed is about $75 \mathrm{ft}$ (fig. 40).

\section{Upper Cherokee, Cherokee, and Lower Cherokee Coal Beds}

The Upper Cherokee coal bed was identified in 390 drill holes and has a maximum thickness of $20 \mathrm{ft}$ and an average thickness of $6.2 \mathrm{ft}$ (figs. 10 and 44). This bed splits from the main Cherokee bed in T. 19 N., R. 92 W. and maintains a thickness of $5 \mathrm{ft}$ or greater for more than $300 \mathrm{mi}^{2}$. The depth to the top of the coal bed ranges from the outcrop along its southeastern extent to more than $1,500 \mathrm{ft}$ along the northern edge of the extent of the bed (fig. 45). The interburden thickness between the bottom of the Upper Cherokee coal bed and the Cherokee coal bed ranges from 1 to as much as $75 \mathrm{ft}$. Cross-section $F-F^{\prime}$ shows how the Upper Cherokee coal bed splits away from the main benches of the Cherokee coal bed. Recoverable resources for the Upper Cherokee coal bed were calculated to be 729 MST, with 48 MST that may be extracted through surface mining methods (fig. 10; tables 3 and 4).

Coal quality data were available from 10 drill holes for the Upper Cherokee coal bed. Average as-received moisture was 22.68 percent, average as-received ash was 15.52 percent, average as-received total sulfur was 1.82 percent, and average as-received specific energy was $7,772 \mathrm{Btu} / \mathrm{lb}$. The apparent rank of the Upper Cherokee coal is subbituminous C.

The thickest bed in the Overland coal zone is the Cherokee coal bed. The Cherokee coal bed, in areas where all the benches of coal bed are combined, has the best potential for surface mine development of the Overland Member coal beds. The bed was identified in 603 drill holes and has a maximum thickness of $45 \mathrm{ft}$, with an average thickness of $8.1 \mathrm{ft}$ (figs. 10 and 46). The bed maintains a thickness of $5 \mathrm{ft}$ or greater for an areal extent of more than $650 \mathrm{mi}^{2}$. The depth to the top of the bed ranges from where the bed crops out along its southeastern extent to more than 1,500 $\mathrm{ft}$ along the northern and southern extents of the bed (fig. 47). Recoverable resources for the Cherokee bed were calculated to be 2.51 BST, with 396 MST that may be extracted using surface mining methods (fig. 10; tables 3 and 4).

A detailed geological analysis of the Cherokee coal interval, where closely spaced drilling is available, shows that it consists of five individual coal beds (denoted as benches numbered 1 through 5, from bottom to top; figs. 40 and 43). Bench 1 is the Lower Cherokee coal bed (described by Hettinger and others, 2008). Benches 2 and 3 form the main portion of the Cherokee coal bed, with the combined thickness of the two benches ranging from about 18 to $25 \mathrm{ft}$. Bench 2 is frequently separated from bench 3 by a thin parting. The two remaining benches overlie bench 3 . Where the parting between benches 3 and 4 is less than $5 \mathrm{ft}$, all 5 combined benches form a Cherokee coal bed that is more than $40 \mathrm{ft}$ thick. Where benches 4 and 5 are separated by more than $5 \mathrm{ft}$ from bench 3, they form the Upper Cherokee bed (for the purposes of this report). The five benches defined for the Cherokee coal bed are shown in a geologic cross section through the thickest portion of the Cherokee coal zone (fig. 43). Each bench shown in figure 43 is color coded to make the lateral continuity of the benches easier to follow. The separation of benches 4 and 5 from bench 3 is well defined in the drill holes in the center of the cross section. A paleochannel feature that causes the parting between benches 1 and 2 to locally thicken to more than $20 \mathrm{ft}$ can be seen in drill hole number CR251-1AS; (fig. 43). This paleochannel feature can be traced laterally in a northwest-southeast trend through the area of the detailed geological analysis.

The interburden thickness between the bottom of the Cherokee coal bed and the top of the Lower Cherokee coal bed ranges from 1 to as much as $75 \mathrm{ft}$ (fig. 40). The thickest interburden is encountered away from the margins of the thick coal zone where the individual coal beds within the Cherokee coal zone thin and split.

Coal quality data were available from 32 drill holes for the Cherokee coal bed. Average as-received moisture was 22.38 percent, average as-received ash was 13.53 percent, average as-received total sulfur was 1.91 percent, and average as-received specific energy was $8,109 \mathrm{Btu} / \mathrm{lb}$. The apparent rank of the Cherokee coal is subbituminous B.

The Lower Cherokee coal bed is also combined with the Cherokee coal bed in T. 19 N., R. 92 W., splitting off to the north, west, and southwest. This bed was identified in 481 drill 
holes and has a maximum thickness of $14 \mathrm{ft}$, with an average thickness of $5.1 \mathrm{ft}$ (figs. 10 and 48). The Lower Cherokee has an areal extent of about $265 \mathrm{mi}^{2}$ with $5 \mathrm{ft}$ or greater coal thickness. The depth to the top of the bed ranges from where the bed out crops along its southeastern extent to more than $1,500 \mathrm{ft}$ along the northern and southern edges of the extent of the bed (fig. 49). Recoverable resources for the Lower Cherokee bed were calculated to be 564 MST, with all but 2 MST being classified as deep mine recoverable resources (fig. 10; tables 3 and 4). The interburden thickness between the bottom of the Lower Cherokee coal bed and the top of the Cow Butte coal bed is about $75 \mathrm{ft}$ (fig. 40).

Coal quality data were available from 10 drill holes for the Lower Cherokee coal bed. Average as-received moisture was 21.76 percent, average as-received ash was 19.77 percent, average as-received total sulfur was 3.01 percent, and average as-received specific energy was 7,289 Btu/lb. The apparent rank of the Lower Cherokee coal is subbituminous $\mathrm{C}$.

\section{Cow Butte Coal Bed}

Identified in 266 drill holes, the Cow Butte coal bed has a maximum thickness of $28 \mathrm{ft}$, with an average thickness of $8.8 \mathrm{ft}$ (figs. 10 and 50). Along the crop line, the coal thickness exceeds $15 \mathrm{ft}$ for several square miles. The depth to the top of the bed ranges from where the bed crops out along its southeastern extent to more than $1,500 \mathrm{ft}$ along the western and northern edges of the extent of the bed (fig. 51). The interburden thickness between the bottom of the Cow Butte coal bed and the top of the Horse Butte coal bed is about $25 \mathrm{ft}$ (fig. 40). Recoverable resources for the Cow Butte bed were calculated to be 537 MST, with 46 MST that may be extracted through surface mining methods (fig. 10; tables 3 and 4).

Coal quality data were available from 12 drill holes for the Cow Butte coal bed. Average as-received moisture was 19.80 percent, average as-received ash was 20.34 percent, average as-received total sulfur was 3.56 percent, and average as-received specific energy was 7,547 Btu/lb. The apparent rank of the Cow Butte coal is subbituminous B.

\section{Horse Butte Coal Bed}

The Horse Butte coal bed was identified in 490 drill holes and is the deepest correlated bed in the Overland coal zone (figs. 10 and 52). This bed has the greatest areal extent of coal beds in the coal zone, covering an area of about $860 \mathrm{mi}^{2}$, with a thickness of $5 \mathrm{ft}$ or greater. Maximum thickness of the bed is $19 \mathrm{ft}$, with an average thickness of $8 \mathrm{ft}$ (fig. 10). The bed thins out to the north and south; however, unlike the other coal beds in this formation, it appears to maintain a thickness of about $5 \mathrm{ft}$ along its western extent. The depth to the top of the bed ranges from where the bed crops out along its southeastern extent to more than $1,500 \mathrm{ft}$ along the northern and southern edges of the extent of the bed (fig. 53). Recoverable resources for the Horse Butte were calculated to be approximately 4.1 BST, with 43 MST that may be extracted through surface mining methods. (fig. 10; tables 3 and 4).
Coal quality data were available from 10 drill holes for the Horse Butte coal bed. Average as-received moisture was 23.81 percent, average as-received ash was 9.03 percent, average as-received total sulfur was 1.04 percent, and average as-received specific energy was $8,576 \mathrm{Btu} / \mathrm{lb}$. The apparent rank of the Horse Butte coal is subbituminous B.

\section{China Butte Coal Zone}

The interval between the bottom of the Overland coal zone and the underlying China Butte coal zone ranges in thickness from about 1,300 to 2,400 ft. The China Butte coal zone has the largest areal extent of the seven coal zones discussed in this report (fig. 15) and underlies almost the entire assessment area. All the beds crop out along the eastern extent of the zone (fig. 54). Initial dips at the outcrop can exceed 20 degrees $\left(^{\circ}\right)$ and flatten to less than $5^{\circ}$ at depths exceeding $6,000 \mathrm{ft}$. The China Butte coal zone is within the following BLM coal tracts (fig. 12): Red Rim, China Butte, Stagecoach, Cedars, Red Monument, and Baggs (Bureau of Land Management and U.S. Geological Survey, 1983). The Red Rim and China Butte coal tracts are within the Union Pacific Railroad land grand area. These coal beds were drilled by Rocky Mountain Energy to depths of about 2,600 ft (Donald Ballard, Anadarko Land Corporation, oral comm., 2013).

During the 1970s, the USGS collected geophysical data (Edson and Curtiss, 1976) and later mapped (Hettinger and others, 2008) the Little Snake River coal field from the Colorado-Wyoming State line northward for about $12 \mathrm{mi}$. Most of the coal beds in the China Butte coal zone were named in outcrop mapping and are used in this assessment. Type localities for most of the beds were provided in Honey and Hettinger (1989). The type sections were provided to resolve correlation problems as beds were named. Hettinger and others (2008) synthesized the Fort Union Formation stratigraphy and associated coal bed sequences from prior work. Data used to assess coal resources in the China Butte coal zone came from 981 coal test holes, 830 oil and gas wells, and 369 measured sections.

A map of the composite coal thickness for the China Butte coal zone was constructed to show the overall areal extent of the zone (fig. 54). The maximum composite thickness of all beds in the China Butte coal zone is about $90 \mathrm{ft}$ near the center of the basin. The China Butte coal zone constitutes almost the entire China Butte Member. The map also shows thicker accumulations of coal along outcrop areas and within the deep, western part of the basin.

The China Butte coal zone, from the top of the Chicken Springs coal bed to the base of the Continental Divide coal bed, ranges in thickness from about $500 \mathrm{ft}$ in the southern part of the assessment area to about $1,500 \mathrm{ft}$ in the northern part of the assessment area. There are 19 named coal beds in the China Butte coal zone in the assessment area (figs. 10 and 55). Thirteen of these beds were modeled for resources: Chicken Springs, Fillmore Ranch/Baggs, Fillmore Creek, Muddy Creek/ Five Mile Point, Separation Creek B, Lower Separation Creek, Riner, Lower Riner, Wild Cow, Olson Draw, Lower Olson 
Draw, Red Rim, and Daley Ranch. The thickness, depth to coal, and reliability coverages for all 19 coal beds in the China Butte coal zone are in Haacke (2018). Resource calculations, based on reliability classification and ownership for these 13 beds are provided in tables 3 and 4. Original resources for the China Butte Member of the Fort Union Formation were calculated to be about 36.3 BST. After coal losses because of land-use and technical restrictions were subtracted, recoverable resources totaled approximately $6.3 \mathrm{BST}$. Recoverable coal resources that may be extracted using surface mining methods were 228 MST, with the remaining recoverable coal resources having to be extracted using underground mining methods.

Cross sections $\left(G-G^{\prime}, H-H^{\prime}\right.$, and $\left.I-I^{\prime}\right)$ show that, in general, the coal beds of the China Butte coal zone of the Fort Union Formation dip steeply from east to west along their outcrops, becoming less steep farther into the Washakie Basin to the west (figs. 56 through 58). Cross section $G-G^{\prime}$ (fig. 56) shows a west-east profile of coal beds through the center of the zone and illustrates the lateral continuity that these coal beds and the interburden thickness between the beds throughout the assessment area. Cross section $H-H^{\prime}$ (fig. 57) is a southwest-northeast profile of the beds and shows the influence of the Wamsutter arch in the middle of the section. The lateral continuity of the beds throughout the section is evident. Cross section $I-I^{\prime}$ (fig. 58) is a west-east profile of the laterally continuous Chicken Springs and Fillmore Ranch/Baggs coal bed. The cross section illustrates the thin interburden between the Chicken Springs and Fillmore Ranch/Baggs coal beds in comparison to the thick interburden between the Fillmore Ranch/Baggs, Wild Cow, and Lower Olson coal beds. This thin interburden relation compared with the other coal beds is only true along cross section $I-I^{\prime}$. Interburden thicknesses are fairly uniform along cross sections $G-G^{\prime}$ and $H-H^{\prime}$.

\section{Chicken Springs Coal Bed}

The Chicken Springs coal bed is the uppermost bed identified in the China Butte coal zone (figs. 10 and 59). This bed has a maximum thickness of $16 \mathrm{ft}$ at depths less than $50 \mathrm{ft}$ in T. 20 N., R. 90 W. The bed was identified in 462 well logs and has an average thickness of $5.7 \mathrm{ft}$. The depth to the top of the bed ranges from the outcrop along its eastern extent to more than 1,500 $\mathrm{ft}$ along the western edge of the extent of the bed (fig. 60). Recoverable resources for the Chicken Springs bed were calculated to be $114 \mathrm{MST}$, although only $10 \mathrm{MST}$ of that total can be extracted through surface mining methods (fig. 10; tables 3 and 4). The interburden thickness between the bottom of the Chicken Springs coal bed and the top of the Fillmore Ranch/Baggs coal bed is about $70 \mathrm{ft}$ (fig. 55).

Coal quality data were available from nine drill holes for the Chicken Springs coal bed. Average as-received moisture was 23.64 percent, average as-received ash was 7.85 percent, average as-received total sulfur was 0.73 percent, and average as-received specific energy was $8,633 \mathrm{Btu} / \mathrm{lb}$. The apparent rank of the Chicken Springs coal is subbituminous C.

\section{Fillmore Ranch/Baggs Coal Bed}

The Fillmore Ranch/Baggs coal bed was named as the Fillmore Ranch coal bed in the northern part of the assessment area and the Baggs coal bed in the southern part of the assessment area (fig. 61). Correlations completed in this assessment determined that the two beds are the same; therefore, in this report the bed will be referred to as the Fillmore Ranch/Baggs coal bed. This bed has the largest areal extent in the assessment area $\left(700 \mathrm{mi}^{2}\right)$ where coal is greater than $5 \mathrm{ft}$ thick and probably has the best potential for mining any of the China Butte Member coal beds. Identified in 901 drill holes, the bed has a maximum thickness of $32 \mathrm{ft}$ and an average thickness of $10.6 \mathrm{ft}$ (fig. 10). There are two separate areas totaling about $28 \mathrm{mi}^{2}$ where the coal thickness exceeds $20 \mathrm{ft}$ : one area is along the crop line in T. 18 N., R. $91 \mathrm{~W}$. and the other is north of the Colorado-Wyoming State line where the bed is more than $1,500 \mathrm{ft}$ deep. The depth to the top of the coal bed ranges from the outcrop along its eastern extent to approximately 6,460 ft (fig. 62). Recoverable resources for the Fillmore Ranch/Baggs coal bed were calculated to be 2.523 billion short tons (BST). Recoverable coal resources that may be extracted through surface mining methods total 136 MST.). The interburden thickness between the bottom of the Fillmore Ranch/Baggs coal bed and the top of the Fillmore Creek coal bed is about $55 \mathrm{ft}$ (fig. 55).

Coal quality data were available from 16 drill holes for the Fillmore Ranch/Baggs coal bed. Average as-received moisture was 24.78 percent, average as received ash was 5.86 percent, average as-received total sulfur was 0.34 percent, and average as-received specific energy was $8,643 \mathrm{Btu} / \mathrm{lb}$. The apparent rank of the Fillmore Ranch/Baggs coal is subbituminous C.

\section{Fillmore Creek Coal Bed}

Identified in 466 drill holes, the maximum thickness of the Fillmore Creek coal bed is $14 \mathrm{ft}$, with an average thickness of $4 \mathrm{ft}$ (figs. 10 and 63). The bed rarely exceeds $5 \mathrm{ft}$ thick, and reaches a maximum depth of more than 6,500 ft (fig. 64). Recoverable resources for the Fillmore Creek coal bed were calculated to be 2 MST with no recoverable resources that can be extracted through surface mining methods (fig. 10; tables 3 and 4). The interburden thickness between the bottom of the Fillmore Creek coal bed and the top of the Muddy Creek U3 coal bed is about $100 \mathrm{ft}$.

\section{Muddy Creek U3 Coal Bed}

The Muddy Creek U3 coal bed was identified in 35 drill holes and has a maximum thickness of $9.8 \mathrm{ft}$, with an average thickness of $4.5 \mathrm{ft}$ (fig. 10). This bed was not assessed for resources because of the limited drill hole data and limited areal extent. The interburden thickness from the bottom of the Muddy Creek U3 coal bed and the top of the Muddy Creek and Five Mile Point coal bed is about $10 \mathrm{ft}$ (fig. 55). 


\section{Muddy Creek/Five Mile Point Coal Bed}

The Muddy Creek/Five Mile Point coal bed was named the Muddy Creek coal bed in the northern part of the assessment area and the Five Mile Point coal bed in the southern part of the assessment area (Hettinger and others, 2008). Correlations in this assessment determined that these two beds are stratigraphically equivalent and will be referred to in this report as the Muddy Creek/Five Mile Point coal bed. Identified in 847 drill holes, it has a maximum thickness of $22 \mathrm{ft}$ and an average thickness of $5.3 \mathrm{ft}$ (figs. 10 and 65). There are two areas where the bed is considerably thicker. The first is in the northwestern part of the assessment area (roughly centered in T. 20 N., Rs. 94 and 95 W.) where the bed is more than 20 feet thick and at a depth of more than 3,000 ft. The second area is along the Colorado-Wyoming State line where the bed is more than $20 \mathrm{ft}$ thick and at a depth of more than 1,500 ft. The depth to the top of the bed ranges from the outcrop along its eastern extent to approximately 6,320 ft (fig. 66). Available surface minable resources for the Muddy Creek/Five Mile Point coal bed were calculated to be 594 MST, although only 8 MST of that total may be extracted through surface mining methods (fig. 10; tables 3 and 4). The interburden thickness between the bottom of the Muddy Creek /Five Mile Point coal bed and the top of the Separation Creek coal bed is about $80 \mathrm{ft}$ (fig. 55).

Coal quality data were available from 12 drill holes for the Muddy Creek/Five Mile Point coal bed. Average as-received moisture was 25.24 percent, average as-received ash was 6.17 percent, average as-received total sulfur was 0.36 percent, and average as-received specific energy was 8,610 Btu/lb. The apparent rank of the Muddy Creek/Five Mile Point coal is subbituminous $\mathrm{C}$.

\section{Separation Creek, Separation Creek B, and Lower Separation Creek Coal Beds}

The Separation Creek coal bed was identified in 130 drill holes and has a maximum thickness of $14 \mathrm{ft}$, with an average thickness of $5.4 \mathrm{ft}$ (fig. 10). This bed was not assessed for resources because of its limited areal extent. The interburden between the bottom of the Separation Creek coal bed and the top of the Separation Creek B coal bed is about $35 \mathrm{ft}$ (fig. 55). All three coal beds may be split off a single parent coal bed, although this was not confirmed in the correlations.

Coal quality data were available from seven drill holes for the Separation Creek coal bed. Average as-received moisture was 23.43 percent, average as-received ash was 8.35 percent, average as-received total sulfur was 0.44 percent, and average as-received specific energy was $8,670 \mathrm{Btu} / \mathrm{lb}$.

The apparent rank of the Separation Creek coal is subbituminous B. The Separation Creek B coal bed is stratigraphically midway between the Separation Creek and Lower Separation Creek coal beds (Hettinger and others, 2008). This bed was identified in 507 drill holes and has a maximum thickness of $21 \mathrm{ft}$, with an average thickness of $3.3 \mathrm{ft}$ (figs. 10 and 67). About $12 \mathrm{mi}$ west of the outcrop of this bed and along its eastern extent is an area of about $100 \mathrm{mi}^{2}$ where the coal is about 5 to $20 \mathrm{ft}$ thick at depths in excess of 2,500 ft (fig. 67). The depth to the top of the bed ranges from the outcrop to more than 7,000 ft (fig. 68). Recoverable resources for the Separation Creek B coal bed were calculated to be 126 MST, with only $1 \mathrm{MST}$ of that total being extractable using surface mining methods (fig. 10; tables 3 and 4). The interburden thickness between the bottom of the Separation Creek B coal bed and the top of the Lower Separation Creek coal bed is about $50 \mathrm{ft}$ (fig. 55).

Coal quality data were available from one drill hole for the Separation Creek B coal bed. As-received moisture was 19.82 percent, as-received ash was 5.31 percent, as-received total sulfur was 0.34 percent, and as-received specific energy was $9,504 \mathrm{Btu} / \mathrm{lb}$. The apparent rank of the Separation Creek B coal is subbituminous B.

The Lower Separation Creek coal bed, identified in 252 drill holes, is stratigraphically about $100 \mathrm{ft}$ below the Separation Creek coal bed. The maximum thickness of this bed is $14 \mathrm{ft}$, with an average thickness of $4 \mathrm{ft}$ (figs. 10 and 69). The depth to the top of the bed ranges from the outcrop of the bed to approximately 6,150 ft (fig. 70). Recoverable resources for the Lower Separation Creek bed were calculated to be 2 MST (fig. 10; tables 3 and 4). The interburden thickness between the bottom of the Lower Separation Creek coal bed and the top of the Riner coal bed is about $50 \mathrm{ft}$ (fig. 55).

\section{Riner and Lower Riner Coal Beds}

The Riner and Lower Riner coal beds crop out in the northern part of the assessment area. The interburden thickness between these two beds ranges from about 50 to $200 \mathrm{ft}$. The Riner coal bed was identified in 505 drill holes and has a maximum thickness of $15 \mathrm{ft}$, with an average thickness of $5.7 \mathrm{ft}$ (figs. 10 and 71). The depth to the top of the bed ranges from the outcrop of the bed to approximately 6,500 ft (fig. 72). Recoverable resources for the Riner bed were calculated to be 80 MST, with 5 MST that may be extracted through surface mining methods (fig. 10; tables 3 and 4).

Coal quality data were available from seven drill holes for the Riner coal bed. Average as-received moisture was 19.46 percent, average as-received ash was 14.03 percent, average as-received total sulfur was 0.38 percent, and average as-received specific energy was $8,323 \mathrm{Btu} / \mathrm{lb}$. The apparent rank of the Riner coal is subbituminous $B$.

Identified in 573 drill holes, the Lower Riner coal bed has a maximum thickness of $32 \mathrm{ft}$, with an average thickness of $3.7 \mathrm{ft}$ (figs. 10 and 73). This bed has a $5 \mathrm{ft}$ or greater thickness for an area greater than $300 \mathrm{mi}^{2}$. The bed is 10 to $25 \mathrm{ft}$ thick in two areas extending approximately $100 \mathrm{mi}^{2}$ at depths exceeding $3,000 \mathrm{ft}$. The depth to the top of the bed ranges from the outcrop of the bed to approximately 6,500 ft (fig. 74). Recoverable resources for the bed were calculated to be $48 \mathrm{MST}$, although no recoverable coal resources were available for extraction through surface mining methods (fig. 10; tables 3 and 4). The interburden thickness between the bottom of the Riner coal bed and the top of the Wild Cow coal bed is about $45 \mathrm{ft}$ (fig. 55). 
Coal quality data were available from one drill hole for the Lower Riner coal bed. As-received moisture was 19.97 percent, as-received ash was 5.68 percent, as-received total sulfur was 0.47 percent, and as-received specific energy was $9,597 \mathrm{Btu} / \mathrm{lb}$. The apparent rank of the Lower Riner coal is subbituminous B.

\section{Wild Cow Coal Bed}

Identified in 203 drill holes, the Wild Cow coal bed consists of several, small, isolated areas of stratigraphically equivalent coal. The largest area is near the Colorado-Wyoming State line where the bed reaches a maximum thickness of about $15 \mathrm{ft}$, with an average thickness of $4.4 \mathrm{ft}$ (figs. 10 and 75). The depth to the top of the coal bed ranges from the outcrop to approximately 6,100 ft (fig. 76). The interburden thickness between the bottom of the Wild Cow coal bed and the top of the upper Olson Draw coal bed is about $50 \mathrm{ft}$ (fig.55). Recoverable resources for the Wild Cow coal bed were calculated to be 214 MST, although only 2 MST of that total may be extracted using surface mining methods (fig. 10; tables 3 and 4).

\section{Upper OIson Draw, Olson Draw, and Lower Olson Draw Coal Beds}

The Upper Olson Draw coal bed was identified in 124 drill holes and splits off of the Olson Draw coal bed. It has a maximum thickness of $13 \mathrm{ft}$, with an average thickness of $4.2 \mathrm{ft}$ (fig. 10). This bed was not assessed for resources because of its limited areal extent. The maximum interburden thickness between the bottom of the Upper Olson Draw coal bed and the top of the Olson Draw coal bed is about $30 \mathrm{ft}$ (fig. 55).

The Olson Draw bed is laterally continuous, extending from north of I-80 south to the Colorado-Wyoming State line (figs. 10 and 77). Although a very prominent bed, it uniformly pinches out about 10 to $12 \mathrm{mi}$ west of the outcrop of the bed. With a maximum thickness of about $34 \mathrm{ft}$ and an average thickness of $11.0 \mathrm{ft}$, the Olson Draw bed was identified in 756 drill holes (figs. 10 and 77). In areas where the bed attains a thickness of $10 \mathrm{ft}$, the areal extent is about $153 \mathrm{mi}^{2}$; the thickest coal is depths greater than $500 \mathrm{ft}$. The depth to the top of the bed ranges from the outcrop to approximately $6,450 \mathrm{ft}$ (fig. 78). Recoverable resources for the Olson Draw bed were calculated to be $2.061 \mathrm{BST}$, although only $44 \mathrm{MST}$ of that total may be extracted through surface mining methods. 2.7 MST tons of that can be classified as reserves (fig. 10; tables 3 and 4). The maximum interburden thickness between the bottom of the Olson Draw coal bed and the top of the Lower Olson Draw coal bed is about $40 \mathrm{ft}$ (fig. 55).

Coal quality data were available from 30 drill holes for the Olson Draw coal bed. Average as-received moisture was 20.77 percent, average as-received ash was 9.51 percent, average as-received total sulfur was 0.39 percent, and average as-received specific energy was $8,680 \mathrm{Btu} / \mathrm{lb}$. The apparent rank of the Olson Draw coal is subbituminous B.

Identified in 208 drill holes, the Lower Olson Draw coal bed has a maximum thickness of $10 \mathrm{ft}$, with an average thickness of $3.6 \mathrm{ft}$ (figs. 10 and 79). The depth to the top of the bed ranges from the outcrop of the bed to approximately $5,600 \mathrm{ft}$ (fig. 80). The bed was identified in 130 drill holes and has a maximum thickness of $14 \mathrm{ft}$, with an average thickness of $5.4 \mathrm{ft}$ (fig. 10). Recoverable resources for the Lower Olson Draw bed were calculated to be 72 MST, with only 1 MST of the total that may be extracted through surface mining methods (fig. 10; tables 3 and 4). The interburden thickness between the bottom of the Lower Olson Draw coal bed and the top of the Hadsell coal bed is about $90 \mathrm{ft}$ (fig. 55).

\section{Hadsell Draw Coal Bed}

The Hadsell Draw coal bed was identified in 58 drill holes and has a maximum thickness of $11.3 \mathrm{ft}$, with an average thickness of $6.2 \mathrm{ft}$ (fig. 10). This bed was not assessed for resources because of its limited areal extent. The interburden between the bottom of the Hadsell Draw coal bed and the top of the Red Rim coal bed is about $100 \mathrm{ft}$ (fig. 55).

Coal quality data were available from four drill holes for the Hadsell Draw coal bed. Average as-received moisture was 18.03 percent, average as-received ash was 6.83 percent, average as-received total sulfur was 0.32 percent, and average as-received specific energy was 9,461 Btu/lb. The apparent rank of the Hadsell Draw coal is subbituminous B.

\section{Red Rim and Lower Red Rim Coal Beds}

The Red Rim coal bed is a very prominent bed in the northern part of the assessment area and thins and pinches out towards the southern portion of the assessment area. The bed was identified in 636 drill holes and has a maximum thickness of $25 \mathrm{ft}$, with an average thickness of $5.4 \mathrm{ft}$ (figs. 10 and 81). In areas where the bed maintains a thickness of greater than $5 \mathrm{ft}$, it has an areal extent of about $262 \mathrm{mi}^{2}$. In areas where it has a thickness of greater than $10 \mathrm{ft}$, it has an areal extent of about $34 \mathrm{mi}^{2}$. The depth to the top of the bed ranges from its outcrop to more than 5,500 ft (fig. 82). Recoverable resources for the Red Rim bed were calculated to be 479 MST, with $18 \mathrm{MST}$ of the total that may be extracted through surface mining methods (fig. 10; tables 3 and 4). The interburden thickness between the bottom of the Red Rim coal bed and the top of the lower Red Rim coal bed is about $60 \mathrm{ft}$.

Coal quality data were available from 16 drill holes for the Red Rim coal bed. Average as-received moisture was 22.68 percent, average as-received ash was 9.40 percent, average as-received total sulfur was 0.44 percent, and average as-received specific energy was $8,525 \mathrm{Btu} / \mathrm{lb}$. The apparent rank of the Red Rim coal is subbituminous B.

The Lower Red Rim coal bed was identified in 104 drill holes and has a maximum thickness of $7.5 \mathrm{ft}$, with an average thickness of $3.5 \mathrm{ft}$ (fig. 10). This bed was not assessed for resources because of its limited areal extent. The interburden thickness between the bottom of the Lower Red Rim coal bed and the top of the Daley Ranch coal bed is about $25 \mathrm{ft}$. 


\section{Daley Ranch Coal Bed}

Identified in 511 drill holes, the Daley Ranch coal bed is a minor coal in the northern part of the assessment area (figs. 10 and 83). It extends to the western limits of the assessment area where it reaches a maximum thickness of $20 \mathrm{ft}$, with an average thickness of $3.7 \mathrm{ft}$ (fig. 10). Where the thickness is $5 \mathrm{ft}$ or greater, the areal extent is about $287 \mathrm{mi}^{2}$, and where the bed thickness is $10 \mathrm{ft}$ or greater, the areal extent is about $33 \mathrm{mi}^{2}$. The depth to the top of the bed ranges from the outcrop of the bed to approximately $6,875 \mathrm{ft}$ (fig. 84). Recoverable resources for the Daley Ranch bed were calculated to be 2 MST (fig. 10; tables 3 and 4). The interburden thickness between the bottom of the Daley Ranch coal bed and the top of the Continental Divide coal bed is about $100 \mathrm{ft}$ (fig. 55).

Coal quality data were available from two drill holes for the Daley Ranch coal bed. Average as-received moisture was 21.34 percent, average as-received ash was 4.88 percent, average as-received total sulfur was 0.25 , and average as-received specific energy was $9,455 \mathrm{Btu} / \mathrm{lb}$. The apparent rank of the Daley Ranch coal is subbituminous B.

\section{Continental Divide Coal Bed}

The Continental Divide coal bed was identified in 211 drill holes and has a maximum thickness of $9.8 \mathrm{ft}$, with an average thickness of $7 \mathrm{ft}$ (fig. 10). This bed was not assessed for resources because of the limited drill hole data and areal extent.

\section{Paleogene Coal Zone Cross Section}

Figure 85 is a northwest-southeast cross section that illustrates the thickness of Paleogene coal zones in the assessment area. The lateral continuity for the Wasatch, Overland, and China Butte coal zones is pervasive throughout the cross section. The Wasatch and Overland coal zones are separated by less than $1,000 \mathrm{ft}$, whereas the interburden between the Overland and China Butte coal zones is $1,300 \mathrm{ft}$ or greater. Interburden thickness between the China Butte coal zone and the Lance coal zone ranges from about $1,500 \mathrm{ft}$ to about $4,000 \mathrm{ft}$ (Hettinger and others, 1991).

\section{Upper Cretaceous Coal Zones}

Three coal zones of the Upper Cretaceous are present within the assessment area. The youngest is the Lance coal zone in the lower member of the Lance Formation. The Almond coal zone straddles the upper and lower members of the Almond Formation at the top of the Mesaverde Group. The oldest is the Allen Ridge coal zone in the upper portion of the Allen Ridge Formation.

\section{Lance Coal Zone}

The interburden thickness between the base of the China Butte coal zone and the underlying Lance coal zone ranges from about 1,500 ft near the Colorado-Wyoming State line, to about 3,500 ft near I-80. Four coal beds were identified in the Lance coal zone: Lance A, B, C, and D (fig. 10). In T. 20 N., R. $89 \mathrm{~W}$., there was enough drill-hole information to correlate four individual beds (A, B, C, and D). In this area, the Lance coal zone is about $450 \mathrm{ft}$ thick. Only the Lance D coal bed is moderately thick and laterally extensive. Although no individual Lance coal bed thickness or depth of cover maps are included with the figures in this report, bed correlations are in the associated drill hole database (Haacke, 2018).

The geologic map of Hettinger and others (2008) shows drill holes collared in the Fox Hills Sandstone, thereby raising the possibility that these drill holes are in the Fox Hills Sandstone rather than the Lance Formation. However, where the coal beds are followed downdip to oil and gas wells, these coals lie above the Fox Hills Sandstone, as indicated in formation tops. Although the map of Hettinger and others (2008) shows a well-defined Lance-Fox Hills contact, the Lance and Fox Hills are found to intertongue in the assessment area.

Correlations generated for this assessment helped determine that the four coals beds are in the Lance Formation. Depths to the top of the coals range from outcrop to $8,350 \mathrm{ft}$.

Lance Formation coals have been mapped in outcrop in Tps. 15, 16, and $17 \mathrm{~N}$.; however, drill hole information is very sparse downdip from that area, resulting in insufficient data to calculate resources. Even in the measured sections, individual Lance Formation coals rarely exceed $5 \mathrm{ft}$ in thickness. A composite thickness map of all Lance coal zone beds (including correlated and uncorrelated) was constructed to show the overall areal extent of the zone (fig. 86). The interburden thickness between the Lance coal zone and the underlying Almond coal zone ranges from about 2,200 to $3,000 \mathrm{ft}$.

\section{Almond Coal Zone}

The Almond coal zone ranges from 200 to $300 \mathrm{ft}$ thick and consists of intertonguing marine and nonmarine sediments (fig. 10; Hettinger and others, 2008). The Almond Formation is the uppermost formation within the Mesaverde Group and has a very well-defined upper contact with the Lewis Shale. The Almond coal zone extends along the cropline from I-80 south to the Colorado-Wyoming State line.

There are six coal beds identified in the Almond coal zone (fig. 10). The uppermost coal (Garden Gulch) is about 100 to $150 \mathrm{ft}$ below the top of the Almond Formation and is in the upper member of the formation. Below the Garden Gulch coal bed is a 150 - to $200-\mathrm{ft}$ section barren of coal. The remaining five correlated coals are in the lower member of the formation 
and are clustered in the bottom $200 \mathrm{ft}$ of the Almond coal zone. These coal beds, from top to bottom, are the Upper JO Ranch, JO Ranch, Cow Creek Butte, Deep Gulch, and Robertson (fig. 10). Resource calculations based on reliability, depth, and ownership for these six beds are provided in tables 3 through 5 .

The coal beds in the Almond coal zone were named by C.S.V. Barclay (1980a, b) who mapped the Cretaceous-aged deposits in the Little Snake River coal field (Haacke and others, 2016). The uppermost Garden Gulch coal bed was named in cross sections by Barclay (1980a, b). The other coal beds (Upper JO Ranch, JO Ranch, Cow Creek Butte, Deep Gulch, and Robertson) have not been named in any known publications.

However, they were named in drill hole data entered into the NCRDS by Barclay. Data used for the Almond correlations came from 377 coal test holes, 184 coalbed methane wells, 447 oil and gas wells, and 47 measured sections. Coalbed methane wells were perforated over long, coaly and carbonaceous zones rather than individual coal beds. For example, well API 4900721981 had 150 continuous feet perforated, including four coal beds of 1,3,6, and $1 \mathrm{ft}$ thickness, in descending order, totaling only $11 \mathrm{ft}$ of coal.

From the late 1960s to the 1980s, Kemmerer Coal Company conducted exploration drilling in the Savery area (Tps. 12 and 13 N., Rs. 88 and 89 W.) in BLM preference right lease agreement areas (Bureau of Land Management and U.S. Geological Survey, 1983). The Almond coal beds are within the following BLM coal tracts, from north to south: Atlantic Rim, Cow Creek, and Savery. A composite coal thickness map of the Almond coal zone was constructed to show the areal extent of the bed (fig. 87). The total composite thickness of the coal beds in the Almond Formation is about $55 \mathrm{ft}$. The coal beds are within a zone that is approximately $400 \mathrm{ft}$ thick (fig. 87 and 88).

The coal beds in the Almond coal zone (fig. 89) crop out along the eastern edge of the assessment area, dipping westward at about 1 to $2^{\circ}$, then steeper to about $10^{\circ}$ below 1,000 $\mathrm{ft}$. The beds maintain good lateral continuity further into the basin where the dip decreases. The Cow Creek Butte coal bed is the thickest of the coal beds in the coal zone; the interburden between the JO Ranch and Cow Creek Butte coal beds is the thickest, in contrast to the thin interburden between the Deep Gulch and Robertson coal beds.

Original resources for the Almond Formation of the Mesaverde Group were calculated to be about 7.1 BST. After coal losses because of land-use and technical restrictions were subtracted, recoverable resources totaled approximately 2.0 BST. Recoverable coal resources that may be extracted using surface mining methods were 219 MST (tables 3 through 5).

\section{Garden Gulch Coal Bed}

Identified in 193 drill holes, the Garden Gulch coal bed has an areal extent of less than $2 \mathrm{mi}^{2}$ (fig. 10). The coal bed has a maximum thickness of $6.1 \mathrm{ft}$, with an average thickness of $4.3 \mathrm{ft}$ (figs. 10 and 90). The depth to the top of the bed ranges from the outcrop to about 8,000 ft (fig. 91). Recoverable resources for the Garden Gulch bed were calculated to be 27 MST, with all of those resources being extractable through surface mining methods (fig. 10; tables 3 and 4). The interburden thickness between the bottom of the Garden Gulch bed and the top of the upper JO Ranch bed is about $140 \mathrm{ft}$ (fig. 88).

\section{Upper JO Ranch Coal Bed}

Identified in 271 drill holes, the Upper JO Ranch coal bed has a maximum thickness of $10 \mathrm{ft}$, with an average thickness of $3.9 \mathrm{ft}$ (figs. 10 and 92). Despite its name, the Upper JO Ranch coal bed is not a split from the top of the JO Ranch coal bed. The depth to the top of the coal bed ranges from the outcrop to about 9,300 ft (fig. 93). There are two areas of coal thickness greater than $4 \mathrm{ft}$ that crop out in the assessment area: one is in Tps. 18 and 19 N., R. $90 \mathrm{~W}$; the other is in Tps. 14 and 15 N., R. 89 and 90 W. (fig. 92). The interburden thickness between the bottom of the Upper JO Ranch bed and the top of the JO Ranch bed is about $25 \mathrm{ft}$ (fig. 88). Recoverable resources for the Upper JO Ranch coal bed were calculated to be 16 MST, with 14 MST of the total that may be extracted through surface mining methods (fig. 10; tables 3 and 4).

Coal quality data were available from 22 drill holes for the Upper JO Ranch coal bed. Average as-received moisture was 14.97 percent, average as-received ash was 6.84 percent, average as-received total sulfur was 0.77 percent, and average as-received specific energy was 10,295 Btu/lb. The apparent rank of the Upper JO Ranch coal is subbituminous A.

\section{JO Ranch Coal Bed}

The JO Ranch coal bed was identified in 394 drill holes and has a maximum thickness of $21.5 \mathrm{ft}$, with an average thickness of $5 \mathrm{ft}$ (figs. 10 and 94). In areas where the bed is greater than $5 \mathrm{ft}$ thick, the areal extent is about $45 \mathrm{mi}^{2}$. The depth to the top of the bed ranges from the outcrop to more than 9,700 ft (fig. 95). Recoverable resources for the JO Ranch bed were calculated to be 161 MST, although 11 MST may extractable through surface mining methods (fig. 10; tables 3 and 4). The interburden thickness between the bottom of the JO Ranch bed and the top of the Cow Creek Butte bed is about $75 \mathrm{ft}$ (fig. 88).

Coal quality data were available from 28 drill holes for the JO Ranch coal bed. Average as-received moisture was 14.61 percent, average as-received ash was 5.55 percent, average as-received total sulfur was 0.91 percent, and average as-received specific energy was 10,493 Btu/lb. The apparent rank of the JO Ranch coal is subbituminous A. 


\section{Cow Creek Butte Coal Bed}

The Cow Creek Butte coal bed is the thickest coal bed in the Almond coal zone. Identified in 558 drill holes, the bed has a maximum thickness of $27 \mathrm{ft}$, with an average thickness of $7.8 \mathrm{ft}$ (figs. 10 and 96). The bed extends south from I-80 to the Colorado-Wyoming State line. In areas where the coal is at least $5 \mathrm{ft}$ thick, the areal extent is about $375 \mathrm{mi}^{2}$. The areal extent where the coal is greater than $10 \mathrm{ft}$ thick is about $79 \mathrm{mi}^{2}$. Two areas of thick coal crop out along Tps. 16, 17, and $18 \mathrm{~N}$., R. 90 W. Another thick pod crops out in Tps. 12 and 13 N., R. 90 W. (fig. 96). The Cow Creek Butte coal bed may have the best potential for both surface and underground mine development of any of the Almond Formation coal beds. The depth to the top of the bed ranges from the outcrops to more than 10,000 ft (fig. 97). Recoverable resources for the Cow Creek Butte bed were calculated to be 1.193 BST, with 93 MST of that total that may be extractable using surface mining methods. (fig. 10; tables 3 and 4). The interburden thickness between the bottom of the Cow Creek Butte bed and the Deep Gulch bed is about $50 \mathrm{ft}$ (fig. 88).

Coal quality data were available from 32 drill holes for the Cow Creek Butte coal bed. Average as-received moisture was 14.00 percent, average as-received ash was 5.65 percent, average as-received total sulfur was 0.91 percent, and average as-received specific energy was 10,664 Btu/lb. The apparent rank of the Cow Creek Butte coal is subbituminous A.

\section{Deep Gulch Coal Bed}

Identified in 451 drill holes, the Deep Gulch coal bed has a maximum thickness of $19.5 \mathrm{ft}$, with an average thickness of $5.1 \mathrm{ft}$ (figs. 10 and 98). In areas where the coal is $5 \mathrm{ft}$ thick or greater, the areal extent is about $50 \mathrm{mi}^{2}$ (Tps. 17, 18, and 19 N., R. 90 W.). Within that area, an area of $7.5 \mathrm{mi}^{2}$ includes coal that is thicker than $10 \mathrm{ft}$. The depth to the top of the bed ranges from the outcrop to more than 9,800 ft (fig. 99). Recoverable resources for the Deep Gulch bed were calculated to be 79 MST, with 18 MST that may be extracted through surface mining methods (fig. 10; tables 3 and 4). The interburden thickness between the bottom of the Deep Gulch bed and the top of the Robertson bed is about $20 \mathrm{ft}$ (fig. 88).

Coal quality data were available from 36 drill holes for the Deep Gulch coal bed. Average as-received moisture was 12.56 percent, average as-received ash was 10.51 percent, average as-received total sulfur was 1.04 percent, and average as-received specific energy was 10,181 Btu/lb. The apparent rank of the Deep Gulch coal is high volatile bituminous C.

\section{Robertson Coal Bed}

The Robertson coal is the basal correlated coal in the Almond coal zone. The coal bed was identified in 376 drill holes and has a maximum thickness of $23 \mathrm{ft}$, with an average thickness of $6.6 \mathrm{ft}$ (figs. 10 and 100). There are three areas of coal totaling $140 \mathrm{mi}^{2}$ of coal that is greater than $5 \mathrm{ft}$ thick coal and $28 \mathrm{mi}^{2}$ of coal that is greater than $10 \mathrm{ft}$ thick (fig. 100). The northern two areas crop out in Tps. 14, 15, and 16 N., Rs. 89 and $90 \mathrm{~W}$. The third area is present in T. 12 N., Rs. 89 and $90 \mathrm{~W}$. and is 500 to $5,000 \mathrm{ft}$ deep. The depth to the top of the bed ranges from the outcrops to more than $9,400 \mathrm{ft}$ (fig. 101). Recoverable resources for the Robertson bed were calculated to be $521 \mathrm{MST}$, with $55 \mathrm{MST}$ that may be extracted through surface mining methods (fig. 10; tables 3 and 4). The interburden thickness between the Almond coal zone and the Allen Ridge coal zone ranges from about 200 to $500 \mathrm{ft}$.

Coal quality data were available from 15 drill holes for the Robertson coal bed. Average as-received moisture was 12.22 percent, average as-received ash was 10.89 percent, average as-received total sulfur was 0.81 percent, and average as-received specific energy was 10,229 Btu/lb. The apparent rank of the Robertson coal is high volatile bituminous $\mathrm{C}$. The interburden between the Almond coal zone and the Allen Ridge coal zone ranges from about 200 to $500 \mathrm{ft}$. The Pine Ridge Sandstone is included in the interburden.

\section{Allen Ridge Coal Zone}

The Allen Ridge coal zone is also within the Mesaverde Group and is stratigraphically the oldest zone assessed in this report (fig. 10). There is no known surface mapping showing coal beds in this coal zone within the assessment area. The Allen Ridge coal zone is solely defined in this report by limited drill hole data. The available published mapping for the area (Hettinger and others, 2008; Wyoming State Geological Survey, 2014; shows the Mesaverde Formation undifferentiated as well as Miocene and Quaternary formations. All the coals identified as being in the Allen Ridge coal zone were too thin and laterally discontinuous to be correlated.

\section{Regional Depositional Trends}

The coal beds in the Overland, China Butte, and Almond coal zones were deposited in fluvial, deltaic, and shoreline depositional environments along the Cretaceous seaway and are the most widespread and laterally extensive in the assessment area (Flores and Bader, 1999). The most widespread accumulation of thick coals occurs in the China Butte coal zone of the Fort Union Formation. The coal beds of the main body of the Wasatch Formation, which were deposited along the shoreline and deltaic facies of lacustrine environments in an intermontane basin, are the most restricted in areal extent (fig. 15). 


\section{Uranium Content in Coal Beds}

Certain coal beds contain radioactive elements in concentrations high enough to raise concerns about detrimental environmental and health effects when the coal is burned in powerplants. Radioactive elements common in coal beds include uranium, thorium, and their numerous decay products, including radium and radon. Assessment of the radiation exposure from the combustion of coal is dependent on the concentration of radioactive elements in flu gases and associated coal combustion in products or byproducts that remain after combustion (Zielinski and Finkelman, 1997).

Pipiringos (1961) reported that nearly all the coal beds that crop out in the central part of the Great Divide Basin contain from 0.001 to 0.003 percent uranium (fig. 4), with concentrations as high as 0.026 percent uranium in some areas. He identified seven uranium-bearing coal beds in the Wasatch coal zone in the northwestern part of the assessment area (fig. 4). Masursky (1962) reported that uranium-bearing coal underlies approximately $300 \mathrm{mi}^{2}$ of the Red Desert in the east-central part of the Great Divide Basin (fig. 4), with uranium contents ranging from about 0.001 percent to as much as 0.051 percent. The area in Masursky (1962) is adjacent to the eastern margin of the Pipiringos (1961) uranium-bearing assessment area (fig. 4).

The distribution of uranium concentration for approximately 2,000 coal samples from the western United States was reported in Zielinski and Finkelman (1997). In the majority of those samples, concentrations of uranium were about 0.0001 to 0.0004 percent. Similar uranium concentrations were found in a variety of common rocks and soils in the same area. Coals with more than 0.002 percent uranium are rare in the United States, making some of these coals slightly higher in uranium content than in other western U.S. coals.

The highest concentrations of uranium are localized in the carbonaceous rocks unconformably overlain by gravel of possible Miocene age, along the eastern margin of the assessment area in Masursky (1962). The uppermost coal bed contains as much as 0.051 percent uranium near the top of the bed in contrast to a coal bed $40 \mathrm{ft}$ deeper, which contains less than 0.001 percent uranium. Masursky (1962) did not report bed names; therefore, it is only known that the uppermost coal bed he investigated contained the highest concentration of uranium. Masursky (1962) further reported that widespread lower concentrations of uranium in coal ranged from 0.0004 percent in the southwest part of his assessment area to 0.010 percent in the northeast part of his assessment area and averaged about 0.003 percent. Masursky (1962) proposed three possible modes of origin for the uranium and other trace elements, partly supported by available evidence: derivation from hydrothermal solutions rising along faults, leaching from the granite in the Granite Mountains during its weathering and erosion, and leaching from the overlying tuffaceous rocks.

\section{Coal Quality Trends}

Trends in coal quality and coal rank are evident in the coals from the different geologic units within the study area (table 2). The coal beds in the Wasatch coal zone have the highest average percentage ash and total sulfur and the lowest average Btu/lb of all the coal beds in the assessment area. The coal beds in the Overland coal zone have the highest average percentage as-received moisture content of all the coal beds within the assessment area. The Overland coal beds have slightly lower average percentage ash and total sulfur and slightly higher average specific energy values than the overlying Wasatch coal beds. The trend towards lower average as-received moisture, percentage ash, and total sulfur and high specific energy values continues into the China Butte coal beds. Overall, the China Butte coal beds exhibit the lowest average percentage ash and total sulfur within the assessment area. Although the coal beds in the Almond coal zone exhibit the lowest percentage as-received moisture values and highest specific energy values within the assessment area, percentage ash and total sulfur are slightly higher than in the China Butte coal zone.

The apparent rank of the coal beds in each geologic unit also varies within the assessment area. Coal beds within the Wasatch coal zone range from subbituminous $\mathrm{C}$ to subbituminous B, as do the coal beds within the Overland coal zone. Similarly, the apparent coal rank within the China Butte coal zone ranges from subbituminous $\mathrm{C}$ at the top of the zone to subbituminous $\mathrm{B}$ at the base of the zone. The Almond Formation coal beds, which are at greater depths than the Wasatch, Overland, and China Butte coal zones, range in rank from subbituminous A to high volatile bituminous $\mathrm{C}$. The changes in rank probably represent differences in depth of burial and thermal maturation of the coal beds in each geologic unit within the assessment area.

\section{Land-Use Restrictions}

Many factors affect the availability of coal for mining; therefore, a four-step screening process defined in the Code of Federal Regulations (43 CFR §§3420.1-3420.4; Bureau of Land Management, 2016b) was used to determine which areas of Federal coal are acceptable for leasing. The coal leasing unsuitability criteria are listed at 43 CFR $\$ 3461.5$ (Bureau of Land Management, 2016a). These criteria are used to determine if an area is unsuitable for leasing and surface mining and were originally established by the Surface Mining Control and Reclamation Act of 1977 (30 U.S.C. 1201 et seq.). Although developed for lands owned by the Federal Government, many of the unsuitability criteria are also applicable to State- and privately-owned lands (fig. 102). For example, areas containing threatened or endangered plant or animal species are protected from destruction wherever they occur. Municipal watersheds are similarly protected from detrimental actions regardless of who owns the land. Other potential 
restrictions to mining include land-use restrictions such as airports; archaeological areas; coalbed methane wells; oil and gas wells; pipelines; power lines; rivers, lakes, and streams; and towns (fig. 103).

The areas subject to environmental restrictions include buffer zones that surround each restricted area. The location and width of these buffers are typically mandated by Federal or State regulations and may measure hundreds of feet in width at the surface. The assessment methodology in this report was expanded by revising the technique for defining surface restrictions at depth. Previous economic assessments used a standard approach when applying regulatory surface buffers (such as a 300-ft buffer around an inhabited house) below the surface; the surface buffers were simply projected vertically downward through the coal beds to be evaluated. However, a restricted area widens with depth for surface mining operations because of the additional setback distance required to maintain safe minepit highwall angles. Consequently, the deeper a coal bed lies beneath the surface, the larger the restricted area (fig. 104).

Restrictions to mining vary with location and local land management regulations. Therefore, different geographic areas have different mining restrictions and availability considerations.

This report reflects assumptions concerning restrictions to mining based on local practices within the Greater Green River Basin. In addition, the BLM provided guidance concerning restrictions to mining and the distances to be buffered around specific features. A more detailed determination of restrictions and other availability considerations would be necessary as part of leasing and mine-planning phases of property development. The following is a discussion of potential land-use restrictions for the assessment area.

\section{Alluvial Valley Floors}

The Surface Mining Control and Reclamation Act of 1977 (SMCRA) (30 U.S.C. 120 et. seq.) identifies alluvial valley floors where mining would interrupt, discontinue, or preclude farming as area unsuitable for surface coal mining and thus are deemed to be restrictions. In addition, areas outside alluvial valley floors where mining would materially damage the quantity or quality of water supplying alluvial valley floors are unsuitable.

The alluvial valley floors in the assessment area are located tens of miles from any possible future surface mining; therefore, they were not considered a restriction for this assessment.

\section{Coalbed Methane}

Several hundred coalbed methane wells have been drilled in the assessment area. Conflicts in other areas have arisen between coal mining and coalbed methane development. One conflict involves the ownership of coalbed methane and whether it belonged to the owner of the oil-and-gas estate or the owner of the coal estate. The Supreme Court of the United States (1999) resolved this issue in 1999, ruling in Amoco Production Co. v. Southern Ute Tribe [(98-830), 526, U.S. 865 (1999)] that coalbed methane is part of the oil-and-gas estate.
In addition, the court specified the owner of the coalbed methane leases has the right to gain access and to develop its estate, and owners of the land surface should be adequately compensated for damage to their property resulting from coalbed methane extraction. The BLM has established conflict administration zones to guide development of coalbed methane leases in the path of near-term coal mining. In these zones, standard guidelines offer a process for settling conflicts and scheduling development of each resource under a Federal mineral estate. Coalbed methane wells were not considered a restriction for this assessment.

\section{Dwellings and Buildings}

Individual dwellings and buildings that exist outside of incorporated areas are not considered restrictions to mining within the assessment area. These individual structures could be purchased by a coal company, which would then move or raze them in order to proceed with mining. Dwellings and buildings were not considered a restriction for this assessment.

\section{Federal Land Systems}

Almost 65 percent of the available coal resource in the assessment area is owned by the Federal Government and must be leased in order to be mined; therefore, Federal lands were not considered a restriction for this assessment (fig. 103).

\section{Oil and Gas Fields}

The greater Wamsutter oil and gas field is within the assessment area (fig. 103). This field consists of areas that were originally separate fields but have partially coalesced over time as drilling has progressed in the area (Nelson and others, 2010). Current [2017] infrastructure for production and transport of oil and gas in the area includes roads, pipelines, pump houses, and separators. Generally, there is little conflict between coal development and conventional oil and gas development because oil and gas reservoirs are primarily in stratigraphic units below minable coal beds. Where oil and gas development and coal mining occur in the same areas, mining is confined to areas outside a specific buffer distance from wells, pipelines, and other oil and gas structures. Resolution of land-use conflicts between coal mining and the oil and gas field development depend on economic conditions, regulations, and negotiations between oil developers and coal developers.

There are hundreds of oil and gas wells throughout the assessment area. An area around a major cluster of active wells might be eliminated from mining activities until these wells are no longer actively producing or mining activities might proceed around individual active wells given a buffer zone. Conversely, specific wells might be plugged and then reopened after coal mining has concluded. For this assessment, it was assumed that the wells will no longer be actively producing when mining operations reach them and thus they are not considered to be restrictions to mining. 


\section{Pipelines}

There is a network of underground oil and gas pipelines throughout the entire assessment area. Most, if not all, of these pipelines could be moved so that surface mining could proceed.

However, moving and restoring them would represent an added economic cost to mining. In any case, pipelines were not considered to be restrictions to mining for this assessment.

\section{Power Lines}

All power lines within the assessment area could be moved to accommodate surface mining operations. Thus, power lines are not considered a restriction to mining in the assessment area.

\section{Railroads}

There is one main railroad route through the assessment area (figs. 2 and 103). The generally east-west route in the northern part of the assessment area is a rail line of the Burlington Northern Santa Fe Railway that runs parallel to I-80 between Rawlins and Rock Springs, Wyo. The total restricted width for the rail line is $400 \mathrm{ft}$. Because the railroad generally runs parallel to $\mathrm{I}-80$, in some cases, the railroad and I-80 buffers overlap. Where the distance between the railroad and I-80 increases, the resulting area is too small to support a mining operation; therefore, these areas were considered to be a restriction to mining for this assessment.

\section{Rivers, Lakes, and Streams}

There are no major river systems or lakes in the assessment area. Shallow lakes and small ponds within the assessment area could either be temporarily moved during mining or reformed after the mining operation ceased. Such waterways were not considered to be restrictions to mining for this assessment.

\section{Roads}

County roads within the assessment area are not considered to be a restriction to mining because they could easily be relocated or temporarily blocked to allow mining to proceed. However, a number of State and U.S. highways, including I-80, are present within the assessment area (figs. 2 and 103). For this assessment, it is assumed that any State or U.S. highway, except I-80, could be relocated to allow for mining. I-80 can't easily be relocated and is considered a restriction to mining. The total restricted width for $\mathrm{I}-80$ is $450 \mathrm{ft}$.

\section{Towns}

The municipality of Wamsutter is within the assessment area and is a permanent restriction to mining (figs. 2 and 103). In addition to the actual incorporated area, the mining restriction for Wamsutter includes a buffer that extends $300 \mathrm{ft}$ beyond the municipality limit (extraterritorial jurisdiction).

\section{Technical Restrictions}

The technical restrictions subtracted from the remaining coal resources to calculate available coal resources consist of geological factors or mining technology limitations. For coal resources that may be extracted through surface mining methods, technical restrictions include coal lost because of surface weathering, burn, or oxidation ( $25 \mathrm{ft}$ for this assessment) or coal resources eliminated because they exceed the maximum conventional stripping ratio for a coal field or region (greater than 10:1 for this assessment).

For coal resources that may be extracted through underground mining methods, technical restrictions include depths of cover exceeding 3,000 ft and coal beds or portions of coal beds less than $8 \mathrm{ft}$ thick. Technical restrictions for underground mining methods also include portions of coal beds exceeding $15 \mathrm{ft}$ (because of maximum mining height limitations; for example, where a $23 \mathrm{ft}$ thick coal bed may be mined, $0-15 \mathrm{ft}$ may be extracted and considered part of the recoverable resource, the remaining $8 \mathrm{ft}$ exceeds the maximum mining height and, therefore, is considered a technical restriction.

Technical restrictions that may affect both surface and underground methods include geologic anomalies or potentially adverse mining conditions identified through exploration activities and structural dips that exceed $20^{\circ}$.

Mining or Processing LossesFor underground mining methods, coal left as pillars, barrier pillars or blocks, or as buffers around the perimeter of a resource area most likely will never be extracted and are subtracted from the recoverable resources to yield recoverable resources. The amount of coal, as a percent of the resource block, left as pillars, barriers, or buffers can be determined using regional mining analogs. This value will vary depending on the type of underground mining (longwall compared to continuous mining methods), mining conditions, and regulatory statutes. Because underground mining methods utilized may vary, recovery percentages were not considered in this assessment when calculating recoverable resources.

For surface mining methods, coal left in the pit, coal crushed by mining machinery, or lost during transportation is subtracted from the recoverable resources to yield recoverable resources. As with the underground mining methods, regional analogs can be used to determine what percentage of the available coal resources may be lost. Surface mining methods may vary depending on the stripping ratio and coal thickness, so pit, crushing, or transportation losses were not considered when calculating recoverable resources.

The lower BTU, higher moisture coal beds present within the study area typically are not processed through coal cleaning plants, so losses based on the percent recovery of clean coal products were not considered when calculating the recoverable resources in this assessment. It is assumed that any coal produced in the assessment area would be consumed as a raw product by nearby or mine mouth power plants. 


\section{Phase Three-Resources and Reserves}

While the estimates of reserves are important, the relation between reserves and recoverable coal resources is equally important, especially in light of the importance of determining the coal reserve base in all major U.S. coal basins. The coal reserve base includes identified resources that meet specified minimum criteria related to current mining and production practices, including those for quality, depth, thickness, and rank (Wood and others, 1983).

These recoverable coal resources are essentially equivalent to coal resource categories included in the EIA's Estimated Recoverable Reserves (ERR) database (U.S. Energy Information Administration, 1999). The ERR, which is updated by the EIA periodically, is currently [2017] the only published national summary of potentially recoverable coal in the United States. The coal listed in the ERR database is the portion of the DRB coal that may be recoverable, based on regional estimates of coal resource accessibility and mining recovery rates. It is especially important to understand that the coal reserve base may encompass those parts of a resource that have a reasonable potential for becoming economically recoverable within planning horizons that extend beyond those which assume proven technology and current economics. The ERR includes those resources classified as reserves and recoverable coal resources that may be mined in the future.

The following sections provide a discussion and summary of coal resource and reserve volumetrics. Coal resources were classified according to geologic assurances of existence or reliability, which are directly dependent on the density of geologic data points. The different reliability categories - measured ( $0.25 \mathrm{mi}$ from point of measurement), indicated $(0.25-0.75 \mathrm{mi}$ from point of measurement), inferred (0.75-3.0 mi from point of measurement), and hypothetical (greater than $3 \mathrm{mi}$ from point of measurement) - can be established on the basis of distance from a data point (Wood and others, 1983).

\section{Coal Resource Assessment Methodology}

The first step in the calculation of coal resources was converting the grids for surface topography, thickness, top of coal elevation, and base of coal elevation for each coal bed from the final PC/Cores models to ASCII grids. These grids were then exported to ArcMap (Esri, Inc., 2015). A density value of 1,770 short tons per acre per foot was applied to the coal thickness grids to calculate the tonnage of coal contained within each area.

Partings in the coal beds were excluded from the coal resource calculations. Original coal resources were calculated for all coal beds that are at least $3 \mathrm{ft}$ thick. Coal resources under land-use (environmental) and technical restrictions were then subtracted from the original resource to determine recoverable resources. The volume of coal resources available for extraction by surface mining was calculated using a minimum coal thickness of $3 \mathrm{ft}$ and a maximum depth of $300 \mathrm{ft}$. Underground resources were calculated using a minimum overburden thickness of $300 \mathrm{ft}$, a maximum overburden thickness of 3,000 ft, and a coal thickness of 8 to $15 \mathrm{ft}$. As explained in the previous section, the portion of any coal bed exceeding $15 \mathrm{ft}$ thick was discarded from the recoverable resources as a technical restriction. A maximum mining height of $15 \mathrm{ft}$ was used when calculating recoverable underground resources, based on currently available mining equipment and technology.

\section{Influence of Geologic Conditions on Coal Mining}

Geologic conditions, such as structural dip of coal beds, occurrence of faults, other discontinuities within coal beds, and depth of coal beds beneath the land surface, determine whether a coal bed is surface mined or underground mined. A structural dip of $5^{\circ}$ or less is advantageous for both surface and underground mining, whereas a dip of $20^{\circ}$ or greater can make both surface and underground mining difficult (Thomas, 2002). Strata in the assessment area generally dip 2 to $20^{\circ}$ westward on the western flank of the Sierra Madre uplift and are gently folded across the east-west-trending Dad arch and the Wamsutter arch (figs. 1 and 2; Hettinger and others, 2008).

The depth of a coal bed affects coal recovery economics for both surface and underground minable resources. The stripping ratio is the most influential economic factor in the evaluation of surface mining potential (Luppens and others, 2009). For example, using a simple overburden-to-coal thickness ratio method, the stripping ratios for a $10-\mathrm{ft}$ - and a $50-\mathrm{ft}-$ thick coal bed, both at 100-ft depth, would be approximately 10:1 and $2: 1$, respectively. The $2: 1$ ratio area would have a considerable production cost advantage. Most mining companies in the western United States try to extract coal at a stripping ratio of 10:1 or less (Kaiser, 1979; Schobert, 1995); however, greater stripping ratios can be possible if the mines are located adjacent to powerplants, thus reducing transportation costs, or if coal quality parameters are economically favorable. A maximum stripping ratio of 10:1 was used for the economic analysis in this assessment.

If the stripping ratio is too great, underground mining methods may be used. If longwall mining methods are used, mining operations will occur in panels typically 5,000 to $20,000 \mathrm{ft}$ long and 750 to $1,500 \mathrm{ft}$ wide. If unexpected adverse geologic conditions are encountered in the longwall panels, large portions of the reserve may be lost or sterilized. Multiple-section continuous mining methods may be used if longwall mining is not feasible because of geologic conditions. Although less productive than longwall mining methods, continuous mining methods have more flexibility to mine around or away from adverse geologic conditions. 


\section{Coal Resource Results}

Twenty-three 7.5-minute quadrangles (fig. 5; table 1) within the assessment area were evaluated for original surface and underground resources by Dames and Moore Company (1978a-g, 1979a-p). Approximately 75 percent of the Little Snake River coal field and Red Desert assessment area is within these quadrangles. Dames and Moore Company (1978a-g, 1979a-p) reported surface resources for coal beds with cover ranging from 0 to $200 \mathrm{ft}$ deep to be about 1 billion short tons, and underground resources for coal beds with cover ranging from 200 to $3,000 \mathrm{ft}$, about 4.7 billion short tons (table 1). Most of the surface resources were along the eastern edge of the Little Snake River coal field and Red Desert assessment area, extending to the west, downdip into the basin. Total surface and underground resources were about 5.7 billion short tons (table 1).

Surface and underground resources for this assessment were calculated using slightly different limits than those used by Dames and Moore Company. Surface resources were calculated for coal beds with cover from 0 to $300 \mathrm{ft}$ deep, and underground resources were calculated for coal beds with cover from 300 to $3,000 \mathrm{ft}$ deep. Coal resources were also reported by reliability classification and coal estate ownership (tables 3and 4) for 33 assessed coal beds. With no restrictions applied, the total original resource for these 33 beds was calculated to be about 73.2 BST (tables 3 through 5). This is more than 10 times the coal resources that were calculated by Dames and Moore Company (1978a-g, 1979a-p).

Coal resources lost because of land-use restrictions in this assessment, which include I-80 and the town of Wamsutter, amounted to approximately 4.0 BST (table 5). Approximately $50 \mathrm{BST}$ of the original resource are affected by technical restrictions. Subtraction of the technical and land-use restrictions from the 73.2 BST of original resource leaves approximately 19.4 BST as a recoverable resource (tables 3 through 5). About 13.8 BST (approximately 71 percent; table 5) of the recoverable coal resource can be classified as measured or indicated, which shows a relatively high degree of accuracy in determining resources. Approximately 10.7 BST (55 percent; table 4) of the recoverable resources are owned by the Federal government.

The drill hole data supplied by Anadarko Land Corporation (Donald Ballard, Anadarko Land Corporation, oral commun., 2013) have enhanced the ability to assess resources in the assessment area. This increased data control substantially improved the geological interpretation, including improving coal bed correlations and increased geological assurance for the resource and reserve estimates. These data substantiate the need for periodic assessments of coal resources as additional geologic data become available or as new technology is implemented.

\section{Surface Coal Resource Results}

Of the 33 modeled coal beds, 12 had sufficient recoverable coal resources (greater than $40 \mathrm{MST}$ at a stripping ratio of 10:1 or less) to warrant evaluation for reserves. Recoverable coal resources in these 12 coal beds may be extracted using surface mining methods totaled just over 2.0 BST. These modeled coal beds are in areas where they crop out along the eastern and southeastern margins of the assessment area (figs. 21-23, 44-45, 58-59, and 91). For the China Butte and Almond coal zones, the areal extent of surface minable resources is limited because of the steep dip of the beds where the depth to the coal bed rapidly increases away from the outcrop. For the Wasatch and Overland coal zones, the dip of the beds is much less, allowing more areal extent of the coal to be surface mined. Within the Wasatch coal zone, a total of about 1.1 BST of recoverable coal resources that may be extracted using surface mining methods a stripping ratio of 1:1 to 10:1 are present in 4 coal beds (Monument, Lower Sourdough, Creston, and Latham; table 6). Stripping ratios were calculated for 4 beds in the Overland coal zone (Upper Cherokee, Cherokee, Cow Butte, and Horse Butte). At a stripping ratio of 1:1 to 10:1, 547 MST of recoverable coal resources may be extracted using surface mining methods. Within the China Butte coal zone, 2 coal beds, Fillmore Ranch/Baggs and Olson Draw, total 180 MST of recoverable coal resources that may be extracted by surface mining methods at a stripping ratio of 1:1 to 10:1. A total of 148 MST of recoverable coal resources may be extracted using surface mining methods at a stripping ratio of 1:1 to 10:1 are present in Cow Creek Butte and Roberson beds of the Almond coal zone.

\section{Underground Coal Resource Results}

Original resources that could be extracted through underground mining methods with depths of cover between 300 feet and 3,000 feet, were calculated to be approximately 66.3 BST for the 33 coal beds in the assessment area (tables 3 and 5). In this assessment, coal resources between 8 feet and 15 feet thick with depths of cover between 300 and $3,000 \mathrm{ft}$ are considered recoverable underground resources, using current mining methods and technology (as previously noted in the Technical Restrictions section). Recoverable underground coal resources that meet the depth of cover and thickness criteria total approximately 17.2 BST, as shown in table 5. Approximately 25 percent of the original underground resources reported in this assessment are considered recoverable resources that can be extracted using underground mining methods. 


\section{Economic Modeling for Coal Reserve Assessment}

Strata in the assessment area generally dip 2 to $20^{\circ}$ westward on the western flank of the Sierra Madre uplift and are gently folded across the east-west-trending Dad arch and the Wamsutter arch (fig. 2; Hettinger and others, 2008; also see "Influence of Geologic Conditions on Coal Mining" section). Similar geologic conditions are noted for the Hanna Basin to the east of the assessment area, which can provide an analog for mining conditions in the assessment area.

General coal and rock deposits in the Hanna Basin and the assessment area appear to have several common characteristics. The BLM determined that extremely weak roof, weak floor, and soft coal conditions existed within the Shoshone No. 1 Mine (Barron and DeMarco, 1995). Although similar weak rock conditions may be projected for the assessment area, too many uncertainties exist to make a more definitive characterization. However, an average pressure gradient was determined for the analog mine. A calibrated gage pressure of 1,250 pounds per square inch was observed at a depth of $1,100 \mathrm{ft}$ or approximately 1.14 pounds per square inch pressure per foot of depth (Barron and DeMarco, 1995). Enough similarities (table 10) can be drawn with the Hanna coal basin as to extend general ground control behavior and design to a hypothetical underground coal mine in the assessment area. This design is largely nondetailspecific, with costs for ground control methods being estimated at a premium to handle unexpected events.

In addition to coalbed correlations and identification of restrictions on coal recovery, a general geological profile was produced for this assessment to identify minable resources. This profile includes coal bed and interburden thicknesses from the Wasatch coal zone down to the Almond coal zone (table 11). Within the Wasatch coal zone, the 8.9-ft-thick Monument coal bed is separated by about $254 \mathrm{ft}$ of interburden from the 11.2-ft-thick Creston coal bed, which is separated by about $111 \mathrm{ft}$ of interburden from the 10.4-ft-thick Latham coal bed. Subsequent coal beds in the underlying coal zones are sufficiently separated to be treated as individual units for recovery.

The geological profile is an average condition representative of an area-wide coal field; the geological conditions it represents are stochastic and nondeterministic. A mining model may be prepared that is stochastic and nondeterministic as well, which matches the geological profile. By being connected with the geological profile, the mining model produces economic results that apply to the entire collection of random points within the assessment area.

\section{Surface Mining Attributes}

USGS mining models are designed as corollaries of an actual mine, with the USGS mining models being used to evaluate the statistical probability of a regional expanse of coal, rather than a site-specific location, for profitability. The surface mining model treats burden removal and coal recovery as volumetric excavation of a sample representation of a large expanse in which multiple sample sizes might fit.

Coal and rock are excavated during surface mining. Each is primarily distinguished by its density. The specific gravity of coal is assumed to be approximately 1.30 (Wood and others, 1983). This is equivalent to about 81 pounds per cubic foot $\left(\mathrm{lb} / \mathrm{ft}^{3}\right)$. The density of sedimentary rock based on Corehole DH104 for the Hanna Basin analog mine has been calculated to be $164 \mathrm{lb} / \mathrm{ft}^{3}$ (Barron and DeMarco, 1995). These are in-place or bank measurements, which become $98 \mathrm{lb} / \mathrm{ft}^{3}$ and $60 \mathrm{lb} / \mathrm{ft}^{3}$ equivalents for rock and coal, respectively, when loosened and excavated. One cubic foot of rock excavated for each cubic foot of coal will yield a 1.63 stripping ratio. The model performs volumetric calculations for both burden and coal but translates and reports coal quantities in mass tonnage.

A typical coal field is a conceptualized form of a "layered cake." Surface mining begins with removing an upper layer (bench) of rock (overburden) to expose a layer of coal. Succeeding coal and noncoal layers (interburden) are exposed and removed from the top downward if more than one coal bed is included. This concept applies for near-surface coal beds, which in this USGS assessment extends from the surface to $300 \mathrm{ft}$ deep. Coal deeper than $300 \mathrm{ft}$ is considered underground minable coal in this assessment. A stair-step excavation is created as the top layer and subsequent lower layers are removed during a timed and staggered excavation. The removed burden is hauled around and behind the excavation and dumped in the void, creating a moving pit as excavation advances laterally.

The hypothetical surface mine design includes several key unit operations and appropriate equipment systems, including the following

- topsoil removal (wheel scrapers);

- breaking and loosening burden layers (blast hole, drill, and explosives truck);

- excavation of high benches (shovel), medium benches (front-end loaders), and low benches or partings (scrapers);

- hauling coal and spoils (rear-dump trucks); and

- reclamation (dozers, graders, and farm equipment).

Mining equipment is the largest cost component in a surface mining model and has been shown to represent 80 to 85 percent of the total capital investment.

Surface coal recovery as discussed in this assessment is largely unaffected by the structural conditions that may be identified during geological correlations. Common mining methods are adapted to excavate parallel to near horizontal bedding planes and slicing through inclined beds for near surface coal deposits. However, mining inclined beds is more expensive because of the additional unit operations needed to mine both burden and coal on each bench. Mining inclined coalbeds also changes the overall operation from a moving strip mine to a static, open pit, in which reclamation involves terracing the stockpile and pit walls and planting on the slope. 


\section{Underground Mining Attributes}

Underground mining usually occurs entirely within a coal bed. Both near-horizontal and inclined coal beds are mined along a preferential stress axis, if such information is available.

Also, mining proceeds preferentially along the strike of inclined and steeply inclined beds, with step developments updip and downdip. Otherwise, in near-horizontally oriented coal beds, development and primary mining are directionally unspecified, but may be dictated by face and (or) butt cleat orientation or by primary and secondary horizontal stress directions.

Underground mining is more sensitive to structural geologic conditions of bed inclination, faulting, floor and roof rolls associated with paleochannels, in-place high horizontal stress (both localized and regional stress fields), and other features. If such features are not present or are minimally defined, then lateral mining boundaries extend to the limits of the assessment area, making the underground mine an open system. A continuous and highly mechanized mining method can be used.

Longwall mining methods provide the most efficient coal recovery when near-uniform conditions exist. Unit operations are generally continuous and provide a smoothing of localized coal bed variations, which eliminates the effects of discontinuities, such as stream channels or oxidized zones. Though substantial coal bed discontinuities can disrupt a real mining operation, their effect is minimalized over the whole expanse of a coal field, which provides the best statistical tool for valuating underground coal beds. Operational continuity is enhanced by continuous cutting of coal facies, supporting overhead and underlying rock layers, and transporting coal to the surface. Generally, little or no noncoal material is mined.

Longwall mining is also inflexible and discontinuities, when encountered, must be mined along with the coal or the operation is halted. The underground mining model is adjusted from longwall to room-and-pillar, using continuous mining methods, when coal bed discontinuities are substantial across the coal field. Although more capable of handling coal bed discontinuities, continuous mining methods have lower productivities and higher operating costs than longwall mining methods.

\section{Mine Model Calculations}

Mining techniques modeled by the USGS were evaluated in a series of Microsoft Excel workbooks. The surface mining model master workbook used for this assessment has 13 spreadsheets; the underground mining model master workbook has 10 spreadsheets. All spreadsheets include formulas or a series of keystrokes (macros) that connect cells to other cells and to end-result tables. A rough estimate of functional elements in the surface mining model master workbook includes 1,103 formulas and macros that use 186 physical inputs and 432 cost items.
The surface and underground mining models are essentially calculators that size and cost equipment units, detail support facilities, list administrative and labor personnel, costs supplies, and include utilities. The size, number, and hourly production rates of loading and haulage machinery are adjusted for burden and coal thicknesses and annual production rates.

\section{Economic Considerations for the Mining Project Simulation}

The hypothetical surface or underground mining model in this assessment simulates an actual mine to a minimal degree. This simulation is limited to a few detailed parameters because accurate inputs were not available. The simulation provides a costing mechanism that, although within a conceptual or order-of-magnitude limit, could still be scoping in nature or somewhat detailed. This limit generally ranges from 50 to 20 percent of a calculated cost down to +30 to -15 percent. Both $\mathrm{a}+50$ percent and $\mathrm{a}+30$ percent overexpense are used, depending upon the level of geologic information available and the detail that can be developed for the mine mode.

A typical mine will go through at least three project periods (preproduction, production, and postproduction). Both preproduction and postproduction can span several years. In the coal assessments in this report, these periods are largely ignored. All preproduction activities and expenses are compressed into a single preproduction year. Postproduction activities, such as remaining reclamation and decommissioning, occur during a final year that follows production. Capital reinvestments to replace equipment systems and degraded facilities occur at intervals throughout the production period. Operating expenses are assumed uniform and are applied as total amounts for each year. The cost of mining is calculated in the surface and underground mining models for various life-of-mine periods $(15,20,25$, and 30 years), though a 20 -year mining duration (length of the production phase) is commonly used in coal assessment calculations.

The depth of coal cover varies over a coal field area, and for surface mining, the stripping ratio increases with depth. The surface mining model does not preferentially advance from one stripping ratio to another but provides parametric values associated with each stripping ratio and the associated costs.

The underground mining model sizes each production panel to correspond with 1 year of operation, which includes setup, coal recovery, and longwall equipment moves. A nearhorizontally oriented coalbed in this arrangement will have 20 production panels. An inclined coalbed will have fewer panels because the weight of the overburden increases to equal the calculated coal strength and additional panels will be expected to fail. 


\section{Coal Recovery Costing}

Component costing is primarily for mining and processing equipment, electrical power, natural gas, labor, suppliers, transportation, and taxes. Additional component detailing is included for construction crew information; hourly and daily output; material, equipment, and base labor costs; overhead and profit allowance for construction; mine setup; demolition; earthwork; materials and handling; and contract services. Both government- and industry-related historical cost indices are incorporated in coal mining assessments. Expenses are separated as direct and indirect capital costs or investments and as operating costs. All costs are treated in escalated dollar values and are discounted to net present value. Contingency cost is applied to the total project investment amount as appropriate for conceptual design. Capital cost depreciation includes options for 200 and 150 percent declining balance and straight line depreciation as applied to the class life of capital assets as specified by the Internal Revenue Service (2015a-c). A distinction is made in the surface and underground models between the tax class life and operating life of the asset. The depreciation approach used provides an accelerated means of cost recovery during early project years but an aggregate amount equal to a more uniform depreciation method (straight line) is produced by the end of an asset life.

\section{Commodity Pricing}

Market pricing in the simulations for this assessment is based on the thermal value of the coal. The assessment market price is based on spot market prices published by the U.S. Energy Information Agency for the Central Appalachian, Northern Appalachian, Powder River, and Uinta basins (table 10). The average heating value in Btu/lb for the Powder River Basin is $8,800 \mathrm{Btu} / \mathrm{lb}$, which most closely compares with the Little Snake River coal beds (EIA, 2019). Relative spot market prices for Little Snake River coal beds are calculated on a direct proportional basis with the average Powder River Basin coal price of $\$ 12.30$ per ST. Potential market prices for coal beds in the Wasatch Formation are calculated as follows:

- $\$ 11.53$ per ST for the Monument coal bed at $8,252 \mathrm{Btu} / \mathrm{lb}$;

- $\$ 11.43$ per ST for the Lower Sourdough coal bed at $8,176 \mathrm{Btu} / \mathrm{lb}$;

- $\$ 10.48$ per ST for the Creston coal bed at 7,501 Btu/lb; and

- $\$ 10.35$ per ST for the Latham coal bed at 7,403 Btu/lb.

A similar price to heating value relation can also be extrapolated for coal beds in the Overland and China Butte Members of the Fort Union Formation and the Almond Formation of the Mesaverde Group.

\section{Discounted Cash Flow for Coal Assessment}

An assumed discounted cash flow rate of return is applied to the time to value-of-money calculations to create a net present value that represents the entire investment for the mining project in current dollar value. The total capital cost at the beginning of the project is added to recurring capital costs during the production phase discounted by the single-payment, present-worth factor. Operating costs uniformly applied for each year of the production period are discounted by the uniform-series, present-worth factor and added after-tax determination to the total investment to produce the total income required for the project.

\section{Breakeven Cost}

The breakeven cost is synonymous with the breakeven price. Both exist at the point between profitability and nonprofitability. The total income required to offset capital and operating cost as derived from the discounted cash-flow rate of return calculation is divided by the tonnage shipped or marketed to produce the breakeven cost, which, in coal assessments, is then compared with a calculated or established market price. Coal that can be mined at a cost less than the market price per ton is denoted as the reserve base. Coal with a mining cost greater than the market price is denoted as recoverable resources.

\section{Assessment of Coal Reserves}

Regional estimates of coal reserves can provide energy planners a more meaningful appraisal of the amount of coal that is realistically recoverable in the foreseeable future. Therefore, another objective of the USGS coal assessment is the systematic determination of the coal reserve base on a regional basis in all major coal provinces in the Nation. Thus, the final step in the third phase of this coal assessment is the completion of an economic analysis to derive estimates of the portion of the recoverable resources that can currently [2019] be classified as reserves.

\section{Surface Mine Reserve Evaluation Results}

Twelve coal beds in the four major coal bed zones were selected for evaluation of reserve potential (table 13). Reserves were calculated for four coal beds in the Wasatch coal zone: Monument, Lower Sourdough, Creston, and Latham. Recoverable resources of approximately $1.1 \mathrm{BST}$, at a stripping ratio of 10:1 or less, are present in these four beds (tables 6 and 7). With a current estimated sales price of $\$ 11.53$ per short ton for the 8,252-Btu/lb-heating value Monument coal bed, about 16.3 MST can be classified as reserves. For the Creston coal bed, with a heating value of 7,501 Btu/lb 10.4 MST can be classified as reserves at a price of $\$ 10.48$ per short ton. The 
Latham coal bed, with a heating value of $7,403 \mathrm{Btu} / \mathrm{lb}$ and the Lower Sourdough coal bed, with a heating value of $8,176 \mathrm{Btu} / \mathrm{lb}$ have no recoverable resources that can be classified as reserves. Therefore, for the Wasatch coal zone, there is only 3.7 MST that can be classified as reserves at the current spot market prices. Of the total recoverable resources of $1.1 \mathrm{BST}$ at a stripping ratio of 1:1 to 10:1 present in these 4 beds, less than 1 percent can be classified as reserves.

Four coal beds in the Overland coal zone were selected to be evaluated for reserve potential: Upper Cherokee, Cherokee, Cow Butte, and Horse Butte. A total of about 547 MST of recoverable resources, at a stripping ratio of 10:1 or less, is present in these four beds (tables 6 and 7). When considering the spot market price of $\$ 11.33$ per short ton for the Cherokee coal bed, about 70 MST would be classified as reserves. At a price of $\$ 11.99$ per short ton for the Horse Butte coal bed, about 4 MST would be classified as be reserves. The total volume from the Overland coal zone that can be classified as reserves are about 74 MST (tables 6 and 7; figs 106-109).

Reserves were calculated for two coal beds in the China Butte coal zone: Fillmore Ranch/Baggs and Olson Draw. A total of $180 \mathrm{MST}$ recoverable resources, at a stripping ratio of 10:1 or less, are present in these two beds (tables 6 and 7). At a spot price of $\$ 12.08$ per short ton and with a $8,463-B t u / l b$-heating value, the Fillmore Ranch/Baggs coal bed has no recoverable coal that can be classified as reserves. The Olson Draw coal bed, with a heating value of 8,680-Btu/lb, 5.5 MST are classified as reserves at a spot price of $\$ 12.13$ per short ton. The total reserves for the China Butte coal zone are 5.5 MST.

Two coal beds in the Almond coal zone were selected to be evaluated for reserve potential: Cow Creek Butte and Robertson. A total recoverable resource of $148 \mathrm{MST}$, at a stripping ratio of 10:1 or less, is present in these two beds (tables 6 and 7). At a spot price of $\$ 14.00$ per short ton and with a 10,664-Btu/lb-heating value, the Cow Creek Butte coal bed has 40.4 MST of coal that can be classified as reserves. The Robertson coal bed, with a heating value of 10,229 Btu/lb and a spot market price of $\$ 14.30$ per short ton, has 20.4 MST that can be classified as reserves. The total reserves for the Almond coal zone are $60.8 \mathrm{MST}$.

At the June 10, 2019 price published by the EIA, total reserves for the assessment area are 167.2 MST. This total is well less than 1 percent of the recoverable total of 2.0 BST.

To derive future reserve estimates for coal beds in the assessment area, cost curves were developed to demonstrate the relation between sales price and estimated reserves (figs. 106 through 109). Cost curves provide a straightforward method of relating recoverable tonnages of coal to market prices of coal. Because a coal reserve estimate is based on a single reference point in time, the use of cost curves is particularly useful in accounting for the typical fluctuations in the market price.

\section{Underground Mine Reserve Evaluation Results}

Coal beds in the Wasatch, Overland, China Butte, and Almond coal zones were evaluated for underground mine reserves. A depth of $800 \mathrm{ft}$ was used to calculate underground mine breakeven price and estimated price for run-of-mine coal in the assessment area. The estimated cost to mine a 10-foot thick coal bed within the assessment area is $\$ 35.93$ per ST. This estimated cost is nearly three times the average spot market price of $\$ 11.99$ per ST. Therefore, by referencing the spot market price of coal in June 2019, it can be determined that there are currently no recoverable coal resources that can be classified as underground reserves in the assessment area.

\section{U.S. Geological Survey Classification of Coal Resources and Reserves}

An explanation of the methodology used by the USGS to classify coal resources and reserves is shown in figure 110 (Luppens and others, 2009). Recoverable coal resources are reported in this assessment study instead of available resources because reserves are calculated from the recoverable coal resources. In this assessment study, available and recoverable resources are identical because mining and processing losses are not considered at the scale of these assessment studies.

\section{Summary}

This assessment presents the results of research to model and map the coal beds in the Little Snake River coal field and Red Desert assessment area (collectively referred to as the assessment area). A total number of 4,214 drill holes and measured sections were used to provide information on the areal extent of coal beds, coal thickness, bed parting thickness, structure, and overburden depth. These data considerably improved the geological interpretation for the area, including verification of previous coal bed correlations and increased geological assurance for the resource and reserve estimates of this assessment.

A three-phase methodology was used for this assessment; the three phases consisted of data collection and processing, geologic modeling and mapping, and calculation of resources and reserves. Regional prefeasibility mine models were developed to evaluate mining economics to estimate the portion of the recoverable resources that meet the definition of reserves.

There are many factors that can affect the availability of coal for mining. About 55 percent of the recoverable resources in the assessment area are under Federal ownership; the remainder is private and State mineral ownership. This distribution limits the amount of land that is available for mining for coal. Landuse and technical restrictions further reduce the amount of coal that is available for mining. 
Coal in the Greater Green River Basin was assessed to include about 73.2 BST of original resources, with approximately 19.4 BST available as recoverable resources after land-use and technical restrictions are subtracted. A total of about 2.1 BST of the 19.4 BST of recoverable resources may be extracted using surface mine methods (with a stripping ratio of less than 10:1). Of the $2.1 \mathrm{BST}$, only $167 \mathrm{MST}$ of coal would be classified as reserves at the spot market price for coal in June 2019.

Although no coal beds in the assessment area are currently (2019) extracted by underground mining methods and no underground mines are known to be planned in the near future, there are substantial underground resources that could be extracted using current underground mining technology. Underground recoverable resources for coal beds 8 to 15 feet (ft) thick and 300 to $3,000 \mathrm{ft}$ deep were estimated to be about 17.2 BST. Because projected underground mining production costs are significantly higher than the current spot market coal prices, there are no underground reserves present in the assessment area.

The average values for specific energy, sulfur, and ash content in coal in the assessment area show that the oldest coal beds contain coal of the best quality and salability. The quality of coal in the younger units, where strip mining could be used, is not as favorable as in the deeper (older) formation coals.

Uranium content in several coal beds in the assessment ranged from 10 to 30 parts per million, which is slightly above the average for coal in the western United States. The coal beds with the highest uranium content are in the Wasatch Formation.

The assessment area mostly contains moderately dipping, thin coal beds, which are not conducive to large surface mining operations. Several localized areas of thick coal associated with the Creston, Cherokee, and Fillmore Ranch/Baggs coal beds are noted in the assessment. Additionally, youngest coal zones contain coal beds that have coal quality that is less favorable than older coal beds.

\section{Acknowledgments}

This report is the product of a long-term effort by many scientists in the U.S. Geological Survey; the results of this study were greatly enhanced by the lifelong work of Robert D. Hettinger, Ronald H. Affolter, and James A. Luppens, retired scientists of the U.S. Geological Survey.

\section{References Cited}

Association for the Advancement of Cost Engineering, 1997, Cost estimate classification system-As applied in engineering, procurement, and construction for the process industries: Association for the Advancement of Cost Engineering International Recommended Practice 18R-97: Morgantown, W. Va., Association for the Advancement of Cost Engineering, $27 \mathrm{p}$.

Association for the Advancement of Cost Engineering, 1999, Skills and knowledge of cost engineering (4th ed.): Morgantown, W. Va., Association for the Advancement of Cost Engineering, [variously paged].

Association for the Advancement of Cost Engineering, 2016, Cost estimate classification system: Morgantown, W. Va., Association for the Advancement of Cost Engineering Recommended Practice 17R-97, 7 p.

Ball, M.W., 1909, The western part of the Little Snake River coal field, Wyoming, in Campbell, M.R. ed., Contributions to economic geology, Part II-Coal and lignite: U.S. Geological Survey Bulletin 341, p. 243-255, 1 pl.

Ball, M.W., and Stebinger, Eugene, 1910, The eastern part of the Little Snake River coal field, Wyoming, in Campbell, M.R., ed., Contributions to economic geology, Part II-Mineral fuels: U.S. Geological Survey Bulletin 381, p. 186-213, 1 pl.

Barclay, C.S.V., 1979a, Geophysical logs and coal sections of holes drilled during 1977 and 1978 in the Browns Hills quadrangle, Carbon County, Wyoming: U.S. Geological Survey Open-File Report 79-1528, 13 p., 79 pls.

Barclay, C.S.V., 1979b, Geophysical logs and coal sections of holes drilled during 1977 and 1978 in the northeastern part of the Baggs quadrangle, Carbon County, Wyoming: U.S. Geological Survey Open-File Report 79-1628, 9 p., 67 pls.

Barclay, C.S.V., 1980a, Geophysical logs and coal sections of holes drilled during 1977 and 1978 in T.15 N., R. 90 and 91 W., Ketchum Buttes and Doty Mountain quadrangles, Carbon County, Wyoming: U.S. Geological Survey Open-File Report 80-488, 16 p., 115 pls.

Barclay, C.S.V., 1980b, Geophysical logs and coal sections of holes drilled during 1977 and 1978 in T.16 N., R. 90 and 91 W., Ketchum Buttes and Doty Mountain quadrangles, Carbon County, Wyoming: U.S. Geological Survey Open-File Report 80-643, 10 p., 122 pls.

Barclay, C.S.V., and Shoaff, L.A., 1977, Lithologic and geophysical logs of holes drilled in the Doty Mountain, Browns Hill, and Baggs quadrangles, Carbon County, Wyoming, during 1976: U.S. Geological Survey Open-File Report 77-171, 77 p., 65 pls. 
Barclay, C.S.V., and Shoaff, L.A., 1978, Lithologic and geophysical logs of holes drilled during 1977 in the Savery quadrangle and southeastern part of the Baggs quadrangle, Carbon County, Wyoming: U.S. Geological Survey OpenFile Report 78-660, 50 p., 58 pls.

Barclay, C.S.V., and Zimmermann, S.C., 1976, Lithologic and geophysical logs of holes drilled in the eastern part of the Doty Mountain quadrangle, Carbon County, Wyoming, by the U.S. Geological Survey during 1975: U.S. Geological Survey Open-File Report 76-510, 108 p., 41 pls.

Barron, L.R., and DeMarco, J.J., 1995, Longwall gate road stability in a steeply pitching thick coal seam with a weak roof: U.S. Bureau of Mines Report of Investigation 9580, 33 p.

Berryhill, H.L., Jr., Brown, D.M., Brown, Andrew, and Taylor, D.A., 1950, Coal resources of Wyoming: U.S. Geological Survey Circular 81, $78 \mathrm{p}$.

Buffler, R.T., 2003, The Browns Park Formation in the Elkhead region, northwestern Colorado-south central Wyoming-Implications for late Cenozoic sedimentation, in Raynolds, R.G., and Flores, R.M., eds., Cenozoic systems of the Rocky Mountain Region: Rocky Mountain Section (Society for Sedimentary Geology) p. 183-212.

Bureau of Land Management and U.S. Geological Survey, 1983, Savery coal—Environmental impact statement: Bureau of Land Management final environmental impact statement, $144 \mathrm{p}$.

Bureau of Land Management, 2016a, Criteria for assessing lands unsuitable for all or certain stipulated methods of coal mining: Code of Federal Regulations, 43 CFR §3461.5, accessed November 12, 2016, at https://www.ecfr.gov/cgi-bin/ text-idx?tpl=/ecfrbrowse/Title43/43cfr3460_main_02.tpl.

Bureau of Land Management, 2016b, Procedures: Code of Federal Regulations, 43 CFR \$3420.1, accessed November 12, 2016, at https:/www.ecfr.gov/cgi-bin/text-idx?tpl=/ ecfrbrowse/Title43/43cfr3420_main_02.tpl.

Carter, M.D., and Gardner, N.K., 1989, An assessment of coal resources available for development: U.S. Geological Survey Open-File Report 89-362, 52 p.

Clarke Energy, [2013], Coal gas: Clarke Energy website, accessed May 7, 2013, at https://Clarke-energy.com/gas-type/coal-gas.

Dames and Moore Company, 1978a, Coal resource occurrence and coal development potential maps of the Creston quadrangle, Carbon and Sweetwater Counties, Wyoming: U.S. Geological Survey Open-File Report 78-622, 24 p., 26 pls.

Dames and Moore Company, 1978b, Coal resource occurrence and coal development potential maps of the Fillmore Ranch quadrangle, Carbon County, Wyoming: U.S. Geological Survey Open-File Report 78-621, 31 p., 38 pls.
Dames and Moore Company, 1978c, Coal resource occurrence and coal development potential maps of the High Point quadrangle, Carbon County, Wyoming: U.S. Geological Survey Open-File Report 78-620, 24 p., 21 pls.

Dames and Moore Company, 1978d, Coal resource occurrence and coal development potential maps of the northwest quarter of the Bridger Pass 15-minute quadrangle, Carbon County, Wyoming: U.S. Geological Survey Open-File Report 78-619, 32 p., 32 pls.

Dames and Moore Company, 1978e, Coal resource occurrence and coal development potential maps of the southeast quarter of the Rawlins Peak 15-minute quadrangle, Carbon County, Wyoming: U.S. Geological Survey Open-File Report 78-617, 28 p., 8 pls.

Dames and Moore Company, 1978f, Coal resource occurrence and coal development potential maps of the southwest quarter of the Bridger Pass 15-minute quadrangle, Carbon County, Wyoming: U.S. Geological Survey Open-File Report 78-649, 21 p., 23 pls.

Dames and Moore Company, 1978g, Coal resource occurrence and coal development potential maps of the southwest quarter of the Rawlins Peak 15-minute quadrangle, Carbon County, Wyoming: U.S. Geological Survey Open-File Report 78-618, 28 p., 18 pls.

Dames and Moore Company, 1979a, Coal resource occurrence and coal development potential maps of the Creston Junction quadrangle, Carbon and Sweetwater Counties, Wyoming: U.S. Geological Survey Open-File Report 79-117, 28 p., 43 pls.

Dames and Moore Company, 1979b, Coal resource occurrence and coal development potential maps of the Duck Lake quadrangle, Carbon County, Wyoming: U.S. Geological Survey Open-File Report 79-1026, 22 p., 14 pls.

Dames and Moore Company, 1979c, Coal resource occurrence and coal development potential maps of the Grieve Reservoir 15-minute quadrangle, Carbon County, Wyoming, and Moffat County, Colorado: U.S. Geological Survey OpenFile Report 79-1037, 16 p. 2 pls.

Dames and Moore Company, 1979d, Coal resource occurrence and coal development potential maps of the Ketchum Buttes quadrangle, Carbon County, Wyoming: U.S. Geological Survey Open-File Report 79-1036, 19 p., 4 pls.

Dames and Moore Company, 1979e, Coal resource occurrence and coal development potential maps of the Mexican Flats quadrangle, Carbon County, Wyoming: U.S. Geological Survey Open-File Report 79-1027, 23 p., 18 pls. 
Dames and Moore Company, 1979f, Coal resource occurrence and coal development potential maps of the northeast quarter of the Baggs 15-minute quadrangle, Carbon County, Wyoming: U.S. Geological Survey Open-File Report 79-1033, 29 p., 26 pls.

Dames and Moore Company, 1979g, Coal resource occurrence and coal development potential maps of the northeast quarter of the Doty Mountain 15-minute quadrangle, Carbon County, Wyoming: U.S. Geological Survey Open-File Report 79-1383, 34 p., 25 pls.

Dames and Moore Company, 1979h, Coal resource occurrence and coal development potential maps of the northwest quarter of the Baggs 15-minute quadrangle, Carbon County, Wyoming: U.S. Geological Survey Open-File Report 79-1384, 21 p., 18 pls.

Dames and Moore Company, 1979i, Coal resource occurrence and coal development potential maps of the northwest quarter of the Doty Mountain 15-minute quadrangle, Carbon County, Wyoming: U.S. Geological Survey Open-File Report 79-1382, 38 p., 32 pls.

Dames and Moore Company, 1979j, Coal resource occurrence and coal development potential maps of the Riner quadrangle, Carbon and Sweetwater Counties, Wyoming: U.S. Geological Survey Open-File Report 79-116, 32 p., 32 pls.

Dames and Moore Company, 1979k, Coal resource occurrence and coal development potential maps of the Savery 15-minute quadrangle, Carbon County, Wyoming: U.S. Geological Survey Open-File Report 79-1085, 24 p. 14 pls.

Dames and Moore Company, 19791, Coal resource occurrence and coal development potential maps of the Seaverson Reservoir quadrangle, Carbon County, Wyoming: U.S. Geological Survey Open-File Report 79-118, 27 p., 31 pls.

Dames and Moore Company, 1979m, Coal resource occurrence and coal development potential maps of the southeast quarter of the Baggs 15-minute quadrangle, Carbon County, Wyoming: U.S. Geological Survey Open-File Report 79-1035, 31 p., 20 pls.

Dames and Moore Company, 1979n, Coal resource occurrence and coal development potential maps of the southeast quarter of the Browns Hill 15-minute quadrangle, Carbon County, Wyoming: U.S. Geological Survey Open-File Report 79-1034, 23 p. 29 pls.

Dames and Moore Company, 1979o, Coal resource occurrence and coal development potential maps of the southeast quarter of the Doty Mountain 15-minute quadrangle, Carbon County, Wyoming: U.S. Geological Survey Open-File Report 79-1032, 28 p. 28 pls.
Dames and Moore Company, 1979p, Coal resource occurrence and coal development potential maps of the southwest quarter of the Doty Mountain 15-minute quadrangle, Carbon County, Wyoming: U.S. Geological Survey Open-File Report 79-1031, 37 p., 27 pls.

Edson, G.M., 1979, Preliminary geologic map of the Seaverson Reservoir quadrangle: U.S. Geological Survey OpenFile Report 79-1577, 2 pls.

Edson, G.M., and Curtiss, G.S., 1976, Lithologic and geophysical logs of holes drilled in the High Point, Seaverson Reservoir, and Fillmore Ranch quadrangles, Carbon County, Wyoming: U.S. Geological Survey Open-File Report 76-272, 57 p., 44 pls.

Eggleston, J.R., Carter, M.D., and Cobb, J.C., 1990, Coal resources available for development-A methodology and pilot study: U.S. Geological Survey Circular 1055, 15 p.

Ellis, M.S., Flores, R.M., Ochs, A.M., Stricker, G.D., Gunther, G.L., Rossi, G.S., Bader, L.R., Schuenemeyer, J.H., and Power, H.C., 1999a, Gillette coalfield, Powder River Basin - Geology, coal quality, and coal resources, chap. PG of 1999 resource assessment of selected Tertiary coal beds and zones in the northern Rocky Mountains and Great Plains region: U.S. Geological Survey Professional Paper 1625-A, [variously paged]. [Also available at https://doi.org/ 10.3133/pp1625A.]

Ellis, M.S., Flores, R.M., Ochs, A.M., Stricker, G.D., Gunther, G.L., Rossi, G.S., Bader, L.R., Schuenemeyer, J.H., and Power, H.C., 1999b, Sheridan coalfield, Powder River Basin-Geology, coal quality, and coal resources, chap. PG of 1999 resource assessment of selected Tertiary coal beds and zones in the northern Rocky Mountains and Great Plains region: U.S. Geological Survey Professional Paper 1625-A, [variously paged]. [Also available at https://doi. org/10.3133/pp1625A.]

Esri, Inc., 2015, ArcGIS software version 10.3.1 for desktop: Redlands, Calif., Esri, Inc., accessed January 23, 2016, at https://www.esri.com/software/arcgis/index.html.

Evans, J.A., 1865, Report of Jas. A. Evans of exploration from Camp Walbach to Green River: Union Pacific Railroad Historical Museum File K-13-1, 24 p.

Finn, T.M., Johnson, R.C., and Roberts, S.B., 2005, The Mesaverde-Lance-Fort Union composite total petroleum system, southwestern Wyoming province, chap. 10, of Petroleum systems and geologic assessment of oil and gas in the southwestern Wyoming province, Wyoming, Colorado, and Utah: U.S. Geological Survey Data Series 69-D, 33 p. [Also available at https://doi.org/10.3133/ds69D.] 
Flores, R.M., and Bader, L.R., 1999, Fort Union coal in the Greater Green River Basin, east flank of the Rock Springs Uplift, Wyoming - A synthesis, chap. GS of 1999 resource assessment of selected Tertiary coal beds and zones in the Northern Rocky Mountains and Great Plains region: U.S. Geological Survey Professional Paper 1625-A, [variously paged]. [Also available at https://doi.org/10.3133/ pp1625A.]

Gardner, A.D., and Flores, V.R., 1989, Forgotten frontier, a history of Wyoming coal mining: Boulder, Colo., Westview Press, 243 p.

Gill, J.R., Merewether, E.A., and Cobban, W.A., 1970, Stratigraphy and nomenclature of some Upper Cretaceous and Lower Tertiary rocks in south-central Wyoming: U.S.

Geological Survey Professional Paper 667, 53 p. [Also available at https://doi.org/10.3133/pp667.]

Glass, G.B., 1978, Wyoming coal fields, 1978: Geological Survey of Wyoming Public Information Circular 9, 91 p. [Also available at http://www.wsgs.wyo.gov/products/ wsgs-1978-pic-09.pdf.]

GRG Corporation, 1998, StratiFact software version 4.57: Wheatridge, Colo., GRG Corporation.

Haacke, J.E., 2018, Drill hole data for coal beds in the Little Snake River coal field and Red Desert area, Greater Green River Basin, Wyoming; U.S. Geological Survey Data Release. Available at: https://doi.org/10.5066/F7RN36RG.

Haacke, J.E., Barclay, C.S.V., and Hettinger, R.D., 2016, Preliminary geologic mapping of Cretaceous and Tertiary formations in the eastern part of the Little Snake River coal field, Carbon County, Wyoming: U.S. Geological Survey Open-File Report 2016-1170, 9 p., data, accessed October 5, 2016, at https://doi.org/10.3133/ofr20161170.

Hale, Derrick, ed., 2016, Heavy construction cost data: Rockland, Mass., R.S. Means Construction Publishers and Consultants, 708 p.

Hayden, F.V., 1879, U.S. geological and geographical survey of the territories (3d ed.): U.S. Geological Survey, $191 \mathrm{p}$.

Hettinger, R.D., and Brown, Robert, 1979, Geophysical and lithologic logs of 1977 coal drilling in the Fort Union Formation, Carbon and Sweetwater Counties, Wyoming: U.S. Geological Survey Open-File Report 79-326, 81 p. [Also available at https://doi.org/10.3133/ofr79326.]

Hettinger, R.D., and Honey, J.G., 2005, Geologic map and coal stratigraphy of the Blue Gap quadrangle, eastern Washakie Basin, Carbon County, Wyoming: U.S. Geological Survey Scientific Investigations Map 2878, scale 1:24,000. [Also available at https://doi.org/10.3133/sim2878].
Hettinger, R.D., and Honey, J.G., 2006, Geologic map and coal stratigraphy of the Doty Mountain quadrangle, eastern Washakie basin, Carbon County, Wyoming: U.S. Geological Survey Scientific Investigations Map 2925, 2 sheets, scale 1:24,000. [Also available at https://doi.org/10.3133/sim2925.]

Hettinger, R.D., Honey, J.G., Ellis, M.S., Barclay, C.S.V., and East, J.A., 2008, Geologic map of Upper Cretaceous and Tertiary strata and coal stratigraphy of the Paleocene Fort Union Formation, Rawlins-Little Snake River area, south-central Wyoming: U.S. Geological Survey Scientific Investigation Map 3053, 3 sheets, 1:100,000 scale. [Also available at https://doi.org/10.3133/sim3053.]

Hettinger, R.D., Honey, J.G., and Nichols, D.J., 1991, Chart showing correlations of Upper Cretaceous Fox Hills Sandstone and Lance Formation, and lower Tertiary Fort Union, Wasatch, and Green River Formations, from the eastern flank of the Washakie basin to the southeastern part of the Great Divide basin, Wyoming: U.S. Geological Survey Miscellaneous Investigations Series Map I-2151, 1 sheet. [Also available at https://doi.org/10.3133/i2151.]

Honey, J.G., 1990, Stratigraphic sections showing coal correlations within the lower coal zone of the Paleocene Fort Union Formation, Riner quadrangle, Carbon and Sweetwater Counties, Wyoming: U.S. Geological Survey Coal Investigations Map C-125, 1 sheet, 1:50,000 scale. [Also available at https://doi.org/10.3133/coal125.]

Honey, J.G., and Hettinger, R.D., 1989, Stratigraphic sections showing coal correlations within the lower coal zone of the Paleocene Fort Union Formation, Fillmore Ranch and Seaverson Reservoir quadrangles, Carbon County, Wyoming: U.S. Geological Survey Coal Investigations Map C-127, 2 sheets, 1:50,000 scale. [Also available at https://doi.org/10.3133/coal127.]

Honey, J.G., and Hettinger, R.D., 2004, Geologic map of the Peach Orchard Flat quadrangle, Carbon County, Wyoming, and description of new stratigraphic units in the Upper Cretaceous Lance Formation and Paleocene Fort Union Formation, eastern Greater Green River Basin, WyomingColorado: U.S. Geological Survey Scientific Investigations Map 2835, version 1.1, 9 p., 1 sheet, scale 1:24,000. [Also available at https://doi.org/10.3133/sim2835.]

InfoMine, Inc., 2015a, Mine and mill equipment costs-An estimator's guide: Spokane Valley, Wash., InfoMine, Inc., accessed December 3, 2016, at http://costs.infomine.com/ miningcostservice/.

InfoMine, Inc., 2015b, Mining cost service: InfoMine, Inc. website, accessed December 3, 2016, at http://costs.infomine.com/ miningcostservice/.

Internal Revenue Service, 2015a, Basis of assets: Internal Revenue Service Publication 551, 13 p. [Also available at https://www.irs.gov/uac/about-publication-551.] 
Internal Revenue Service, 2015b, Business expenses: Internal Revenue Service Publication 535, 54 p. [Also available at https://www.irs.gov/uac/about-publication-535.]

Internal Revenue Service, 2015c, How to depreciate property: Internal Revenue Service Publication 946, 114 p. [Also available at https://www.irs.gov/uac/about-publication-946.]

Jones, N.R., Jones, R.W., and Lucke, D.W., comps., 2011, Coal map of Wyoming: Wyoming State Geological Survey Map Series 93, scale 1:500,000. [Also available at http:// www.wsgs.wyo.gov/products/wsgs-2009-ms-93.pdf.]

Kaiser, W.R., 1979, Gulf coast lignite-A status report [abs.]: Gulf Coast Association of Geological Societies Transactions, v. 29, p. 405.

Kinney, S.A., Haacke, J.E., Miller, R.F., and Harwell, D.E. 2018, Geospatial data for coal beds in the Little Snake River coal field and Red Desert area, Greater Green River Basin, Wyoming: U.S. Geological Survey Data Release. Available at: https://doi.org/10.5066/F7GQ6X2J.

Law, B.E., Spencer, C.W., Charpentier, R.R., Crovelli, R.A., Mast, R.F., Dolton, G.L., and Wandrey, C.J., 1989, Estimates of gas resources in overpressured low-permeability Cretaceous and Tertiary sandstone reservoirs, Greater Green River Basin, Wyoming, Colorado, and Utah, in Eisert, J.L., ed., Gas resources of Wyoming: Wyoming Geological Association, 40th field conference, Guidebook, p. 39-61.

Love, J.D., and Christiansen, A.C., 1985, Geologic map of Wyoming: U.S. Geological Survey map, 3 sheets, scale 1:500,000. [Also available at https://doi. org/10.3133/70046739.]

Luppens, J.A., Rohrbacher, T.J., Osmonson, L.M., and Carter, M.D., 2009, Coal resource availability, recoverability, and economic evaluations in the United States-A summary, chap. D of Pierce, B.S., and Dennen, K.O., eds., The national coal resource assessment overview: U.S. Geological Survey Professional Paper 1625-F, 17 p. [Also available at https://doi.org/10.3133/pp1625F.]

Luppens, J.A., Scott, D.C., Haacke, J.E., Osmonson, L.M., and Pierce, P.E., 2015, Coal geology and assessment of coal resources and reserves in the Powder River Basin, Wyoming and Montana: U.S. Geological Survey Professional Paper 1809, 218 p. [Also available at https://dx.doi.org/10.3133/pp1809.]

Masursky, Harold, 1962, Uranium-bearing coal in the eastern part of the Red Desert area, Wyoming: U.S. Geological Survey Bulletin 1099-B, 152 p., 10 pls. [Also available at https://doi.org/10.3133/b1099B.]
Masursky, Harold, and Pipiringos, G.N., 1953, Uranium-bearing coal in the Red Desert, Great Divide basin, Sweetwater County, Wyoming: U.S. Geological Survey Trace Elements Memorandum 601, 20 p., 7 pls. [Also available at https://doi.org/10.3133/tem601.]

Mentor Consultants, 2005, PC/Cores: Glen Ellyn, Ill., Mentor Consultants software.

Mineral Land Evaluation Committee, 1977, Red Desert known recoverable coal resource area, Sweetwater County, Wyoming: Wyoming Mineral Land Evaluation Committee coal land leasing minutes, no. 9, 20 p., 3 sheets, 1 table.

Mineral Land Evaluation Committee, 1978, Revision of the Rawlins (Little Snake River) known recoverable coal resource area, Carbon and Sweetwater Counties, Wyoming: Wyoming Mineral Land Evaluation Committee coal land leasing minutes, no. 12, 16 p., 3 tables.

Molnia, C.L., Osmonson, L.M., Wilde, E.M., Biewick, L.R.H., Rohrbacher, T.J., and Carter, M.D., 1999, Coal availability and recoverability studies in the Powder River Basin, Wyoming and Montana, chap. PAR of 1999 resource assessment of selected Tertiary coal beds and zones in the northern Rocky Mountains and Great Plains Region: U.S. Geological Survey Professional Paper 1625-A, 119 p. [Also available at https://doi.org/10.3133/pp1625A.]

Naftz, D.L., and Barclay, C.S.V., 1991, Selenium and associated trace elements in soil, rock, water and streambed sediment of the proposed sandstone reservoir, south-central Wyoming: U.S. Geological Survey Water-Resources Investigations Report 91-4000, 9 p., 1 pl. [Also available at https://doi.org/10.3133/wri914000.]

National Mining Association, 2016, Facts about coal and minerals: Washington, D.C., National Mining Association, $37 \mathrm{p}$. [Also available at http://nma.org/wpcontent/ uploads/2016/11/factbook2016-3.pdf.]

Nelson, P.H., Ewald, S.M., Santus, S.L., and Trainor, P.K., 2010, Gas, oil, and water production from Jonah, Pinedale, Greater Wamsutter, and Stagecoach Draw fields in the Greater Green River Basin, Wyoming: U.S. Geological Survey Open-File Report 2009-1290, 19 p., 5 pls., data, accessed November 12, 2016, at https://doi.org/10.3133/ ofr20091290.

Neuendorf, K.K.E., Mehl, J.P., Jr., and Jackson, J.A., eds., 2011, Glossary of geology (5th ed.): American Geosciences Institute, $800 \mathrm{p}$.

Perman, R.C., 1990, Depositional history of the Maastrichtian Lewis Shale in south-central Wyoming-Deltaic and interdeltaic, marginal marine, and trough deep-water marine environments: American Association of Petroleum Geologists Bulletin, v. 74, no. 11, p. 1695-1717. 
Perry, W.J., Jr., and Flores, R.M., 1994, Sequential Laramide deformation and deep gas-prone basins of the Rocky Mountain region, chap. E of Dyman, T.S., Rice, D.D., and Wescott, W. A., eds., Geologic controls of deep natural gas resources in the United States: U.S. Geological Survey Bulletin 2146, p. 49-59. [Also available at https://doi.org/10.3133/b2146.]

Pierce, B.S., and Dennen, K.O., eds., 2009, The national coal resource assessment overview: U.S. Geological Survey Professional Paper 1625-F, 402 p. [Also available at https://doi.org/10.3133/pp1625F.]

Pipiringos, G.N., 1961, Uranium-bearing coal in the central part of the Red Desert area, Wyoming: U.S. Geological Survey Bulletin 1099-A, 104 p., map scale 1:62,500. [Also available at https://doi.org/10.3133/b1099A.]

Pipiringos, G.N., and Masursky, Harold, 1959, Uraniumbearing coal in the Red Desert area, Sweetwater County, Wyoming, chap. G of Uranium in coal in the western United States: U.S. Geological Survey Bulletin 1055, p. 181-215, pls. 36-45. [Also available at https://doi.org/10.3133/b1055.]

Pyles, D.R., and Slat, R.M., 2000, A high-frequency stratigraphic framework for shallow through deep-water deposits of the Lewis Shale and fox Hills Sandstone, Great Divide and Washakie Basins, Wyoming, in Weimer, P., Slat, R.M., Coleman, J., Rosen, N.C., Nelson, H., Bouma, A.H., Styzen, M.J., and Lawrence, D.T., eds., Deep water reservoirs of the world - 20th annual Bob F. Perkins research conference, December 3-6, 2000, Houston, Tex.: Gulf Coast Section Society of Economic Paleontologists and Mineralogists Foundation, poster, p. 836-861.

Roehler, H.W., 1973, Stratigraphic divisions and geologic history of the Laney Member of the Green River Formation in the Washakie Basin in southwestern Wyoming: U.S. Geological Survey Bulletin 1372-E, 28 p. [Also available at https://doi.org/10.3133/b1372E.]

Roehler, H.W., 1988, Geology of the Cottonwood Creek delta in the Eocene Tipton tongue of the Green River Formation, southeast Washakie basin, Wyoming, chap. A of Roehler, H.W., Hanley, J.H., and Honey, J.G., eds., Geology and paleoecology of the Cottonwood Creek delta in the Eocene Tipton tongue of the Green River Formation and a mammalian fauna from the Eocene Cathedral Bluffs Tongue of the Wasatch Formation, southeast Washakie Basin, Wyoming: U.S. Geological Survey Bulletin 1669, p. A1-A14. [Also available at https://doi.org/10.3133/b1669AC.]

Roehler, H.W., 1989, Correlation of surface sections of the intertongued Eocene Wasatch and Green River Formations across the central part of the Sand Wash Basin, northwest Colorado, and eastern part of the Washakie Basin, southwest Wyoming: U.S. Geological Survey Miscellaneous Field Studies Map 2106, 1 pl. [Also available at https://doi.org/10.3133/mf2106.]
Roehler, H.W., 1992, Introduction to Greater Green River Basin geology, physiography, and history of investigations: U.S. Geological Survey Professional Paper 1506-A, 15 p., $1 \mathrm{pl}$. [Also available at https://doi.org/10.3133/pp1506A.]

Sanders, R.B., 1974, Geologic map and coal resources of the Riner quadrangle, Carbon and Sweetwater Counties, Wyoming: U.S. Geological Survey Coal Investigations Map C-68, scale 1:24,000. [Also available at https://doi.org/ 10.3133/coal68.]

Sanders, R.B., 1975, Geologic map and coal resources of the Creston Junction quadrangle, Carbon and Sweetwater Counties, Wyoming: U.S. Geological Survey Coal Investigations Map C-73, scale 1:24,000. [Also available at https://doi.org/10.3133/coal73.]

Schobert, H.H., 1995, Lignites of North America: Amsterdam, The Netherlands, Elsevier Coal Science Technology, v. 23, 696 p.

Schultz, A.R., 1920, Oil possibilities in and around Baxter Basin, in the Rock Springs uplift, Sweetwater County, Wyoming: U.S. Geological Survey Bulletin 702, 107 p. [Also available at https://doi.org/10.3133/b702.]

Smith, E.E., 1909, The eastern part of the Great Divide Basin coal field, Wyoming, in Campbell, M.R. ed., Contributions to economic geology, Part II — Coal and lignite: U.S. Geological Survey Bulletin 341, p. 220-242, 1 pl.

Supreme Court of the United States, 1999, Amoco Production Co. v. Southern Ute Tribe (98-830), 526 U.S. 865 (1999): Supreme Court of the United States web page, accessed May 26, 2017, at https://www.law.cornell.edu/supct/ html/98-830.ZS.html.

Thomas, Larry, 2002, Coal geology: John Wiley and Sons, 365 p.

Thrush, P.W., comp., 1968, A dictionary of mining, mineral, and related terms: U.S. Bureau of Mines, 1,269 p.

U.S. Army Corps of Engineers, 2011, Corpscon version 6.0: U.S. Army Corps of Engineers website, accessed January 6, 2017, at https://www.agc.army.mil/Missions/Corpscon/.

U.S. Energy Information Administration, 1999, U.S. coal reserves - 1997 update: U.S. Energy Information Administration DOE/EIA-0529(97), 60 p., accessed November 7, 2017, at ftp://ftp.eia.doe.gov/pub/pdf/coal.nuclear/052997. pdf. [FTP site no longer available; report was accessed May 26, 2017, at https://permanent.access.gpo.gov/lps89105/ coalres.pdf.]

U.S. Energy Information Administration, 2019a, Coal: U.S. Energy Information Administration web page, accessed June 10, 2019, at https://www.eia.gov/coal/. 
U.S. Energy Information Administration, 2019b, Table 15. Recoverable coal reserves at producing mines, estimated recoverable reserves, and demonstrated reserve base by mining method, 2015: U.S. Energy Information Administration Annual Coal Report 2019, 1 p., accessed June 10, 2019 at https://www.eia.gov/coal/annual/pdf/table15.pdf.

U.S. Geological Survey, [2016]a, The national coal resources data system (NCRDS) database: U.S. Geological Survey database, accessed [date], at https://energy.usgs.gov/Tools/ NationalCoalResourcesDataSystem.aspx.

U.S. Geological Survey, [2016]b, Well catalog: U.S. Geological Survey Core Research Center database, accessed [date you downloaded data from CRC], at https://my.usgs.gov/crewc/.

Witton, E.M., 1999, Outcrop and subsurface characterization of the Lewis Shale, Carbon County, Wyoming: Golden, Colo., Colorado School of Mines M.S. thesis, 214 p.

Wood, G.H., Jr., Kehn, T.M., Carter, M.D., and Culbertson, W.C., 1983, Coal resource classification system of the U.S. Geological Survey: U.S. Geological Survey Circular 891, 65 p. [Also available at https://doi.org/10.3133/cir891.]

Wyoming Oil and Gas Conservation Commission, 2014, Oil and gas wells: Wyoming Oil and Gas Conservation Commission database, accessed December 2014 at http://wogcc.state.wy.us.

Wyoming State Geological Survey, 2014, Wyoming spatial data clearinghouse: Wyoming State Geological Survey website, accessed November 2014 at http://wgiac2.state.wy.us.

Zielinski, R.A., and Finkelman, R.B., 1997, Radioactive elements in coal and fly ash - Abundance, forms, and environmental significance: U.S. Geological Survey Fact Sheet 1997-163, 4 p. [Also available at https://doi.org/10.3133/fs16397.] 
Figures 


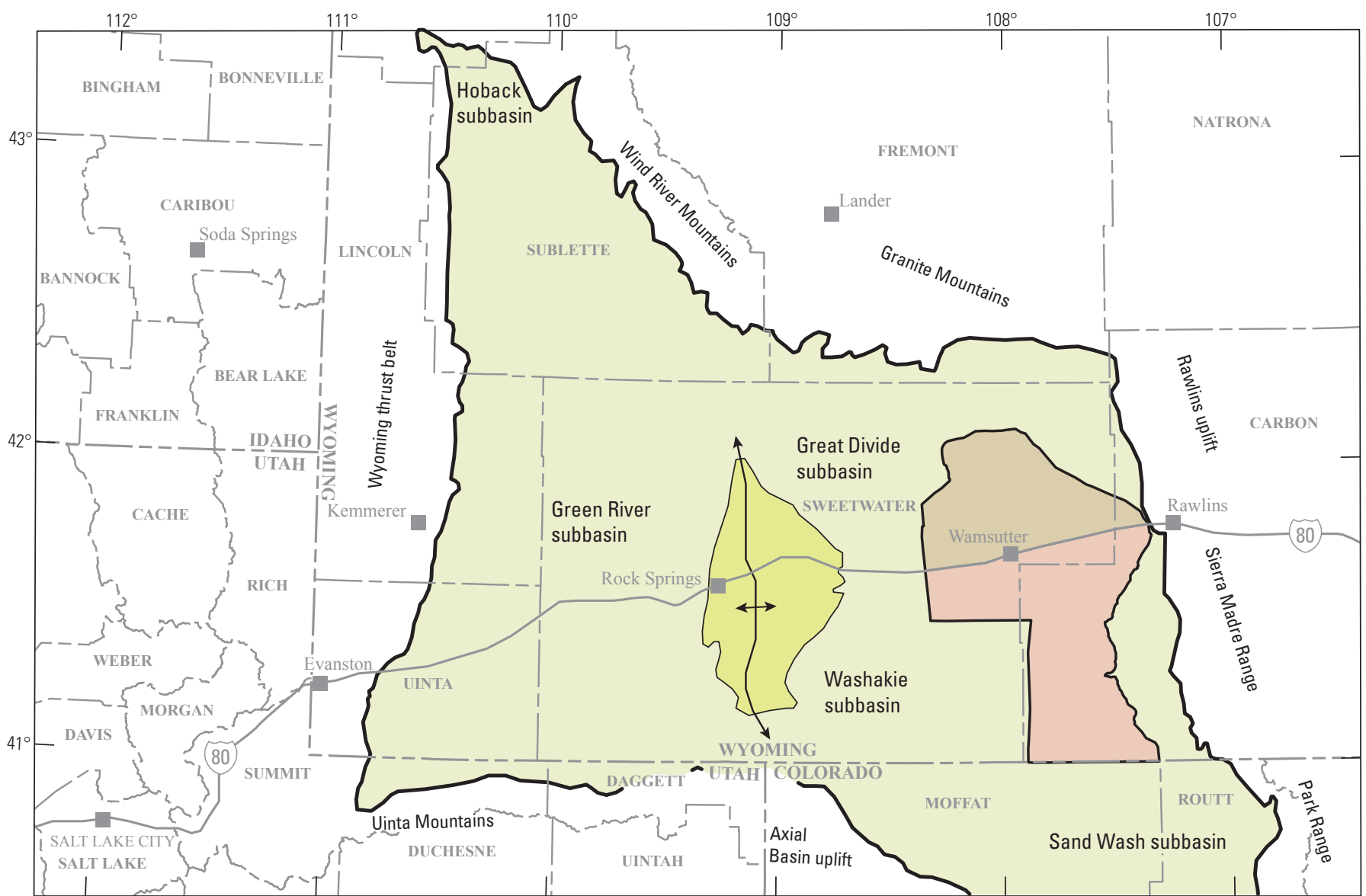

Base map from U.S. Geological Survey

The National Map digital data, 2017

Universal Transverse Mercator, zone $13 \mathrm{~N}$

North American Datum of 1983

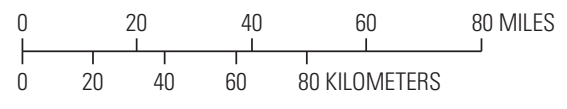

EXPLANATION

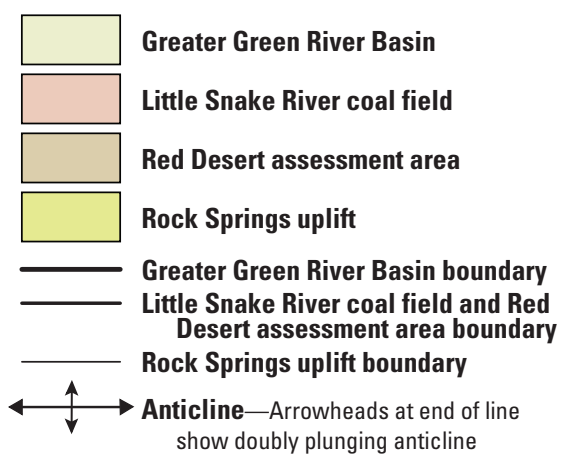

Figure 1. Locations of the Little Snake River coal field and the Red Desert assessment area, subbasins, and major structural features in the Greater Green River Basin, Wyoming. Modified from Roehler (1992). 


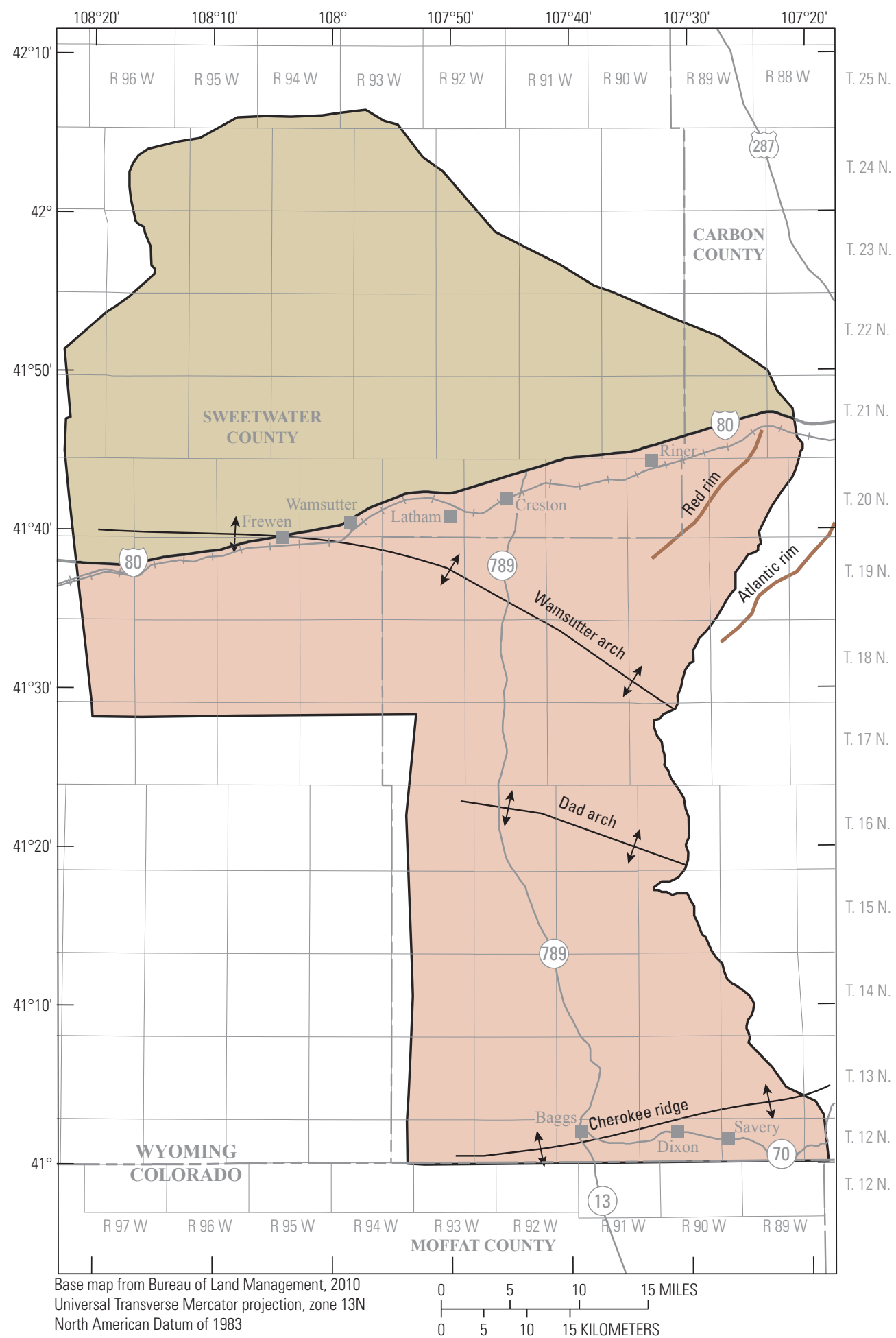

EXPLANATION

Little Snake River coal field

Red Desert assessment area

Little Snake River coal field and Red Desert assessment area boundary

$\underline{\operatorname{Dad} \uparrow a r c h}$

Anticline and name

Red Rim

Geographic feature and name

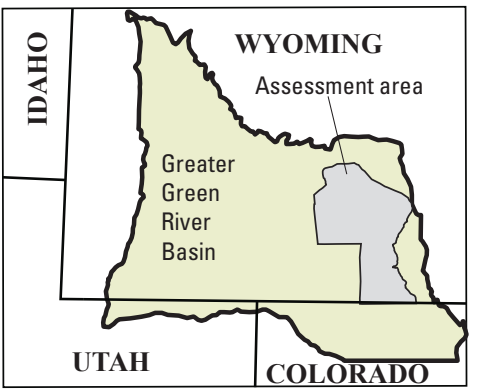

Figure 2. Approximate locations of structural and geographic features in the Little Snake River coal field and Red Desert assessment area, Greater Green River Basin, Wyoming. Modified from Hettinger and others (2008). 


\section{Phase one-Data collection}

- Coal bed geology (extent, thickness, partings, structure, overburden)

- Factors affecting extraction of coal (land-use and technical restrictions)

- State and county jurisdiction and coal ownership

- Coal quality information

- Coal sales price, tax information

\section{Phase two-Geologic modeling}

- Correlate coal beds

- Create coal bed models

- Use geographic information systems to define land-use and technical restrictions by bed

\section{Phase three-Calculation of resources and reserves}

- Calculate tonnages for original resources, mined out areas and restricted areas

- Calculate available resources

- Create mine models to determine reserves

- Calculate mining costs for remaining resources

Figure 3. Generalized U.S. Geological Survey methodology used for coal resource and reserve assessment. 

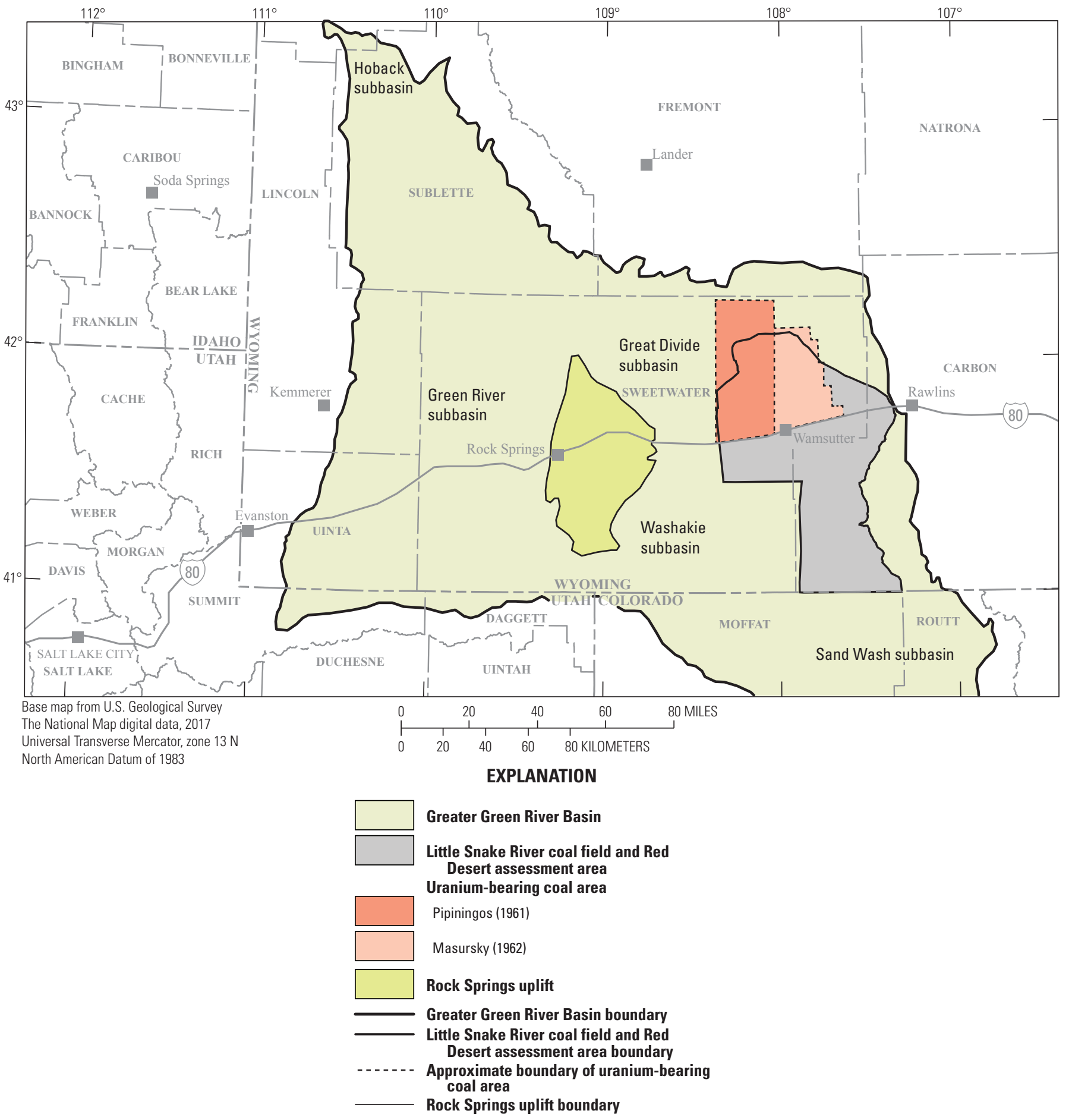

Figure 4. Location of uranium-bearing coal areas in the Little Snake River coal field and Red Desert assessment area in the Greater Green River Basin, Wyoming. Modified from Pipiringos (1961) and Masursky (1962). 


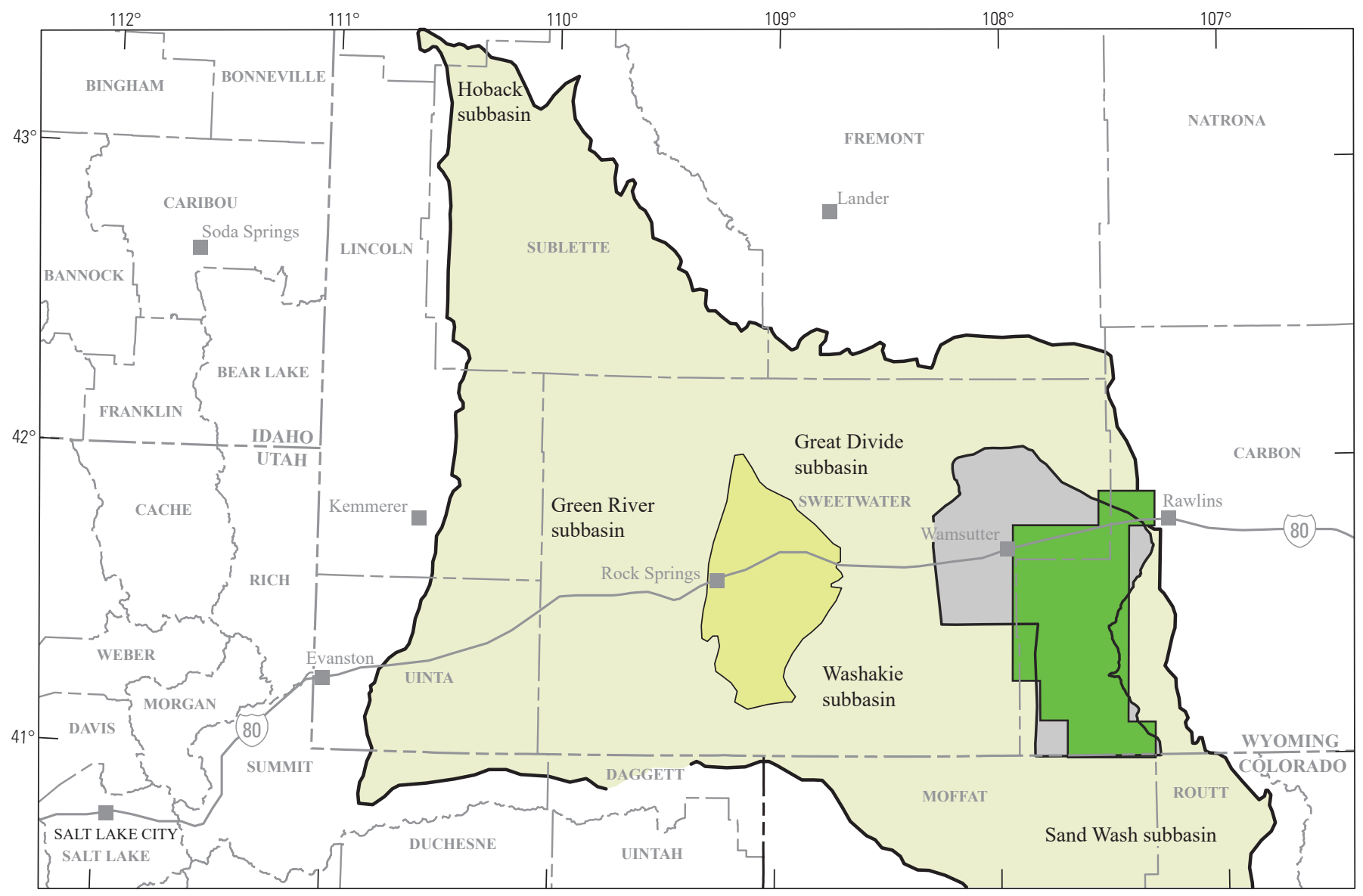

Base map from U.S. Geological Survey The National Map digital data, 2017

Universal Transverse Mercator, zone $13 \mathrm{~N}$ North American Datum of 1983

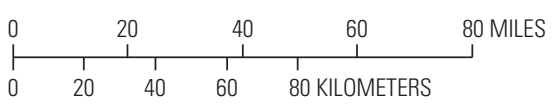

EXPLANATION

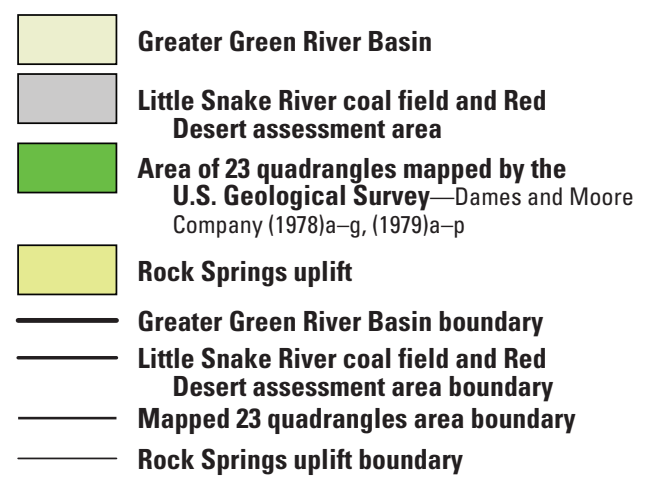

Figure 5. Outline location of 23 quadrangles for coal resource occurrence and coal development potential reports (Dames and Moore Company, 1978a-g, 1979a-p) in the Little Snake River coal field and Red Desert assessment area in the Greater Green River Basin, Wyoming. From Dames and Moore Company (1978a-g, 1979a-p). 


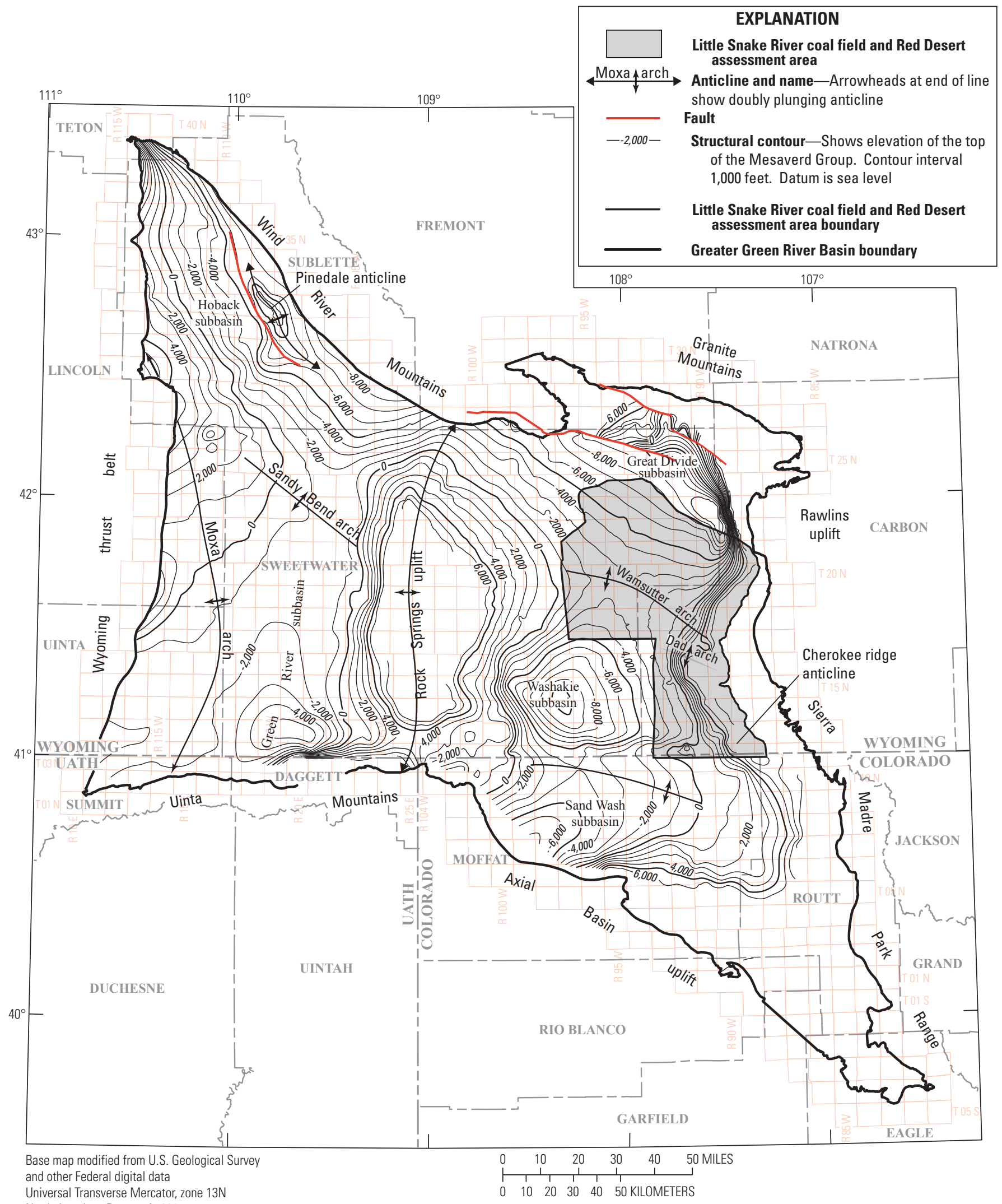

North American Datum of 1983

Figure 6. Structure contours drawn at the top of the Mesaverde Group in the Greater Green River Basin, Wyoming. Modified from Finn and others (2005). 


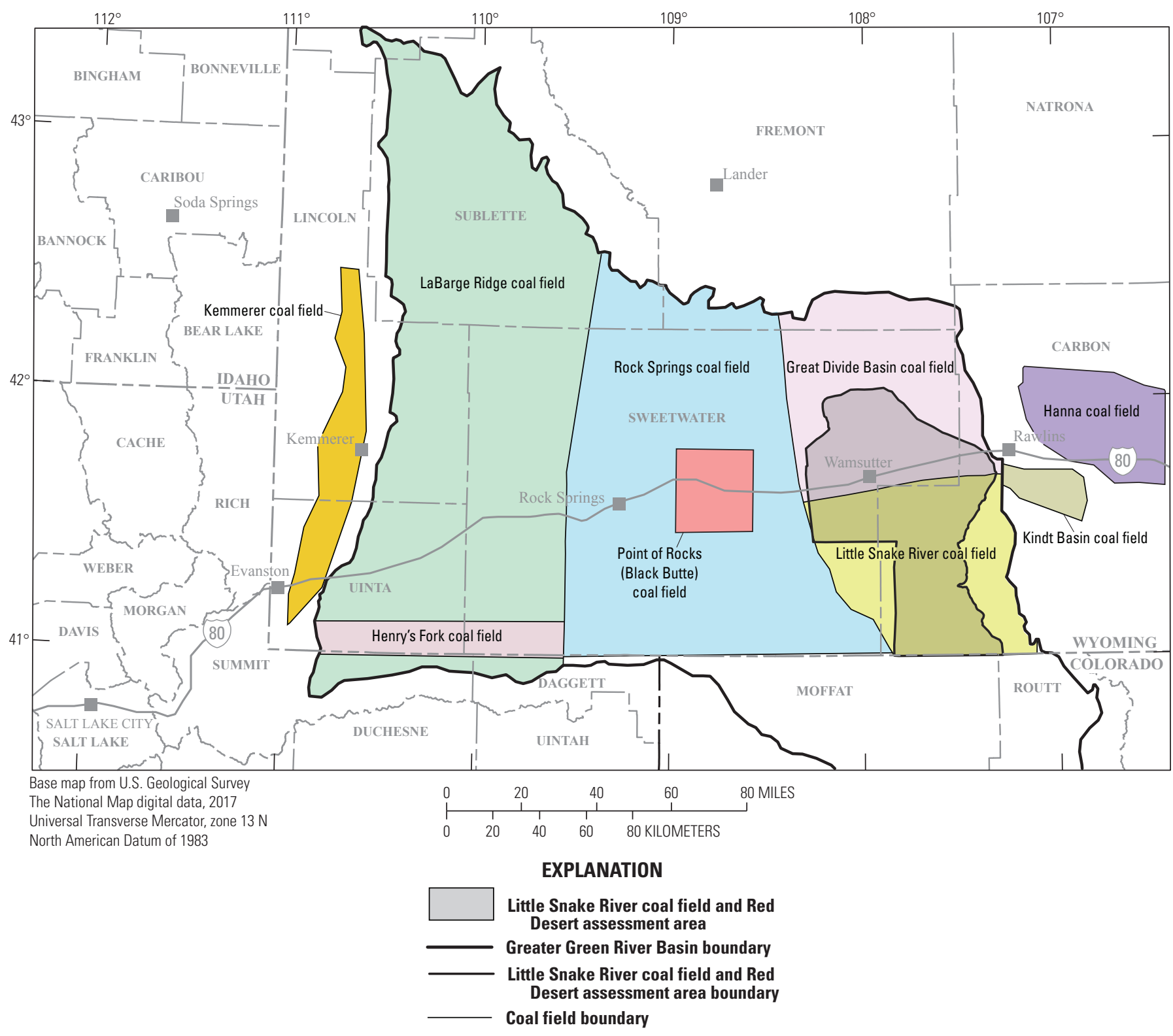

Figure 7. Location of coal fields in the Greater Green River Basin, Wyoming. Modified from Glass (1978) and Ellis and others (1999a,b). 


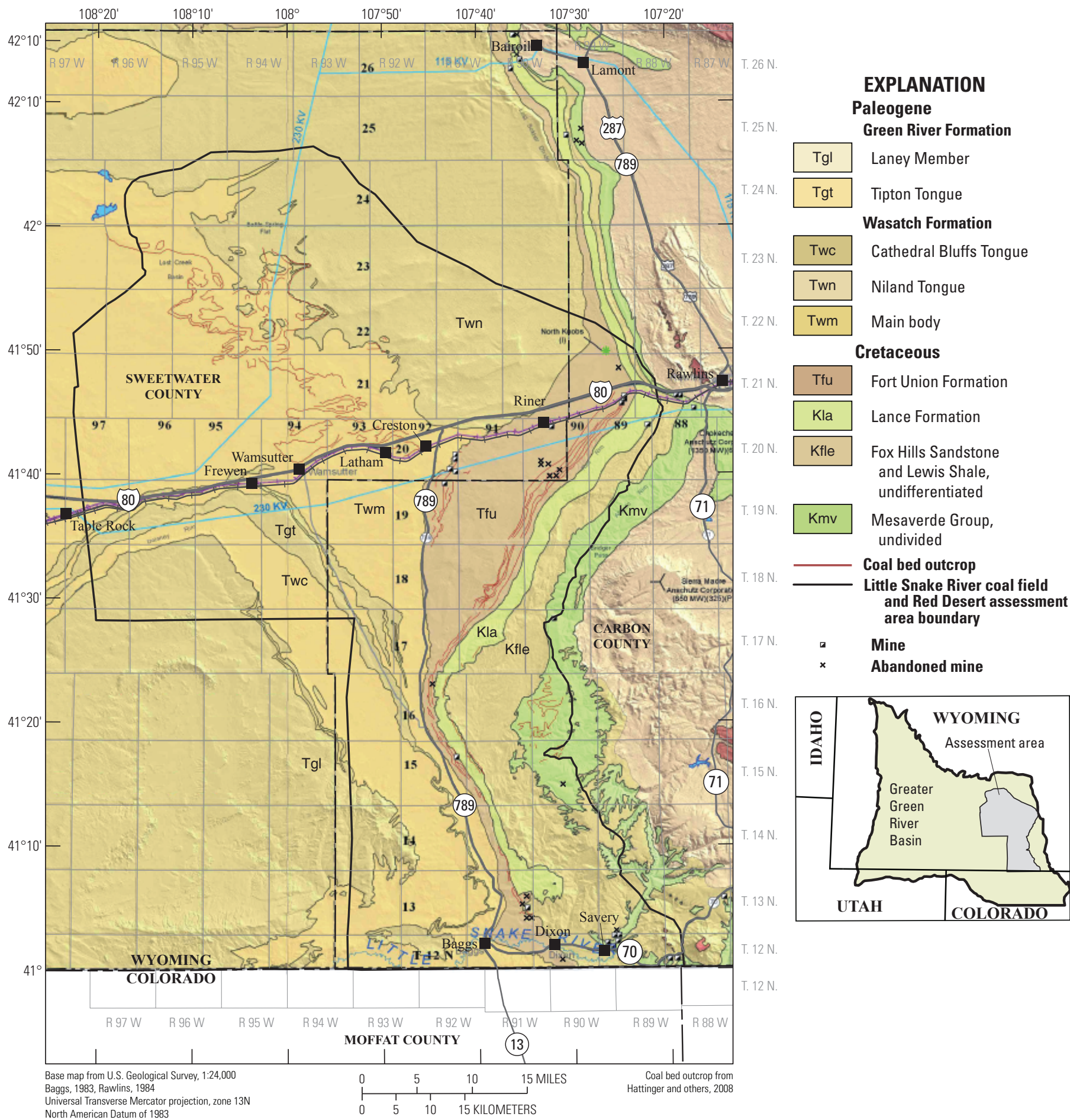

Figure 8. Generalized geology of the Little Snake River coal field and Red Desert assessment area, Greater Green River Basin, Wyoming. Modified from Wyoming State Geological Survey (2011). 
$\boldsymbol{A}$

\begin{tabular}{|c|c|c|c|c|c|}
\hline \multirow[t]{2}{*}{ 음 } & \multirow[t]{2}{*}{$\begin{array}{l}\text { 듬 } \\
\text { 을 }\end{array}$} & \multicolumn{2}{|c|}{$\begin{array}{l}\text { Stratigraphic units in } \\
\text { the Little Snake River } \\
\text { coal field and } \\
\text { Red Desert } \\
\text { assessment area }\end{array}$} & \multirow[t]{2}{*}{$\begin{array}{l}\text { Unit } \\
\text { thickness, } \\
\text { in feet }\end{array}$} & \multirow[t]{2}{*}{$\begin{array}{c}\text { Generalized geologic descriptions of the stratigraphic } \\
\text { units in the Little Snake River coal field and } \\
\text { Red Desert assessment area }\end{array}$} \\
\hline & & Formation & Member & & \\
\hline \multirow{4}{*}{ 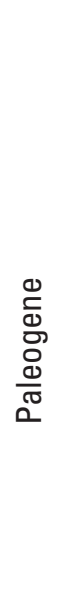 } & 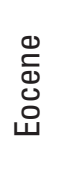 & $\begin{array}{l}\text { Wasatch } \\
\text { Formation }\end{array}$ & $\begin{array}{l}\text { Red Desert } \\
\text { Tongue } \\
\text { (main body- } \\
\text { see text) }\end{array}$ & up to 2,100 & $\begin{array}{l}\text { Predominantly mudstones with occasional interbedded fine-grained sandstones and lenticular, } \\
\text { conglomeratic sandstones. Interpreted as a floodplain deposit north of the Dad arch and forms } \\
\text { gentle slopes in that area. South of the Dad arch, it forms steep badlands topography with } \\
\text { lithologies of various colors (gray, red, maroon, and green). Contains subbituminous } \\
\text { coal beds. }\end{array}$ \\
\hline & \multirow{3}{*}{ 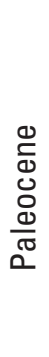 } & \multirow{3}{*}{$\begin{array}{l}\text { Fort Union } \\
\text { Formation }\end{array}$} & $\begin{array}{l}\text { Overland } \\
\text { Member }\end{array}$ & up to 2,100 & $\begin{array}{l}\text { Includes, in descending order, the Cherokee coal interval, a middle fine-grained unit, and a } \\
\text { basal sandstone unit. It appears to lie unconformably on the Blue Gap and China Butte } \\
\text { Members. The Overland Member thins from north to south; it lies unconformably beneath } \\
\text { the Wasatch Formation. }\end{array}$ \\
\hline & & & $\begin{array}{l}\text { Blue Gap } \\
\text { Member }\end{array}$ & $\begin{array}{l}0 \text { to } 570 \text { feet } \\
\text { thick }\end{array}$ & Mostly mudrock \\
\hline & & & $\begin{array}{c}\text { China Butte } \\
\text { Member }\end{array}$ & up to 2,100 & $\begin{array}{l}\text { Sandstones, siltstones, mudrock, carbonaceous shale, and coal beds; basal part of member } \\
\text { consists of conglomerates and conglomeratic sandstones. Contains subbituminous } \\
\text { coal beds. }\end{array}$ \\
\hline \multirow{10}{*}{ 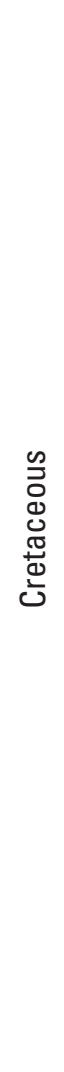 } & \multirow{10}{*}{ 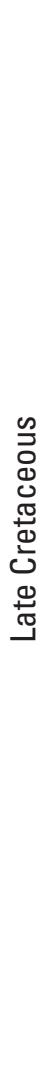 } & \multirow{2}{*}{$\begin{array}{l}\text { Lance } \\
\text { Formation }\end{array}$} & $\begin{array}{l}\text { Red Rim } \\
\text { Member }\end{array}$ & up to 900 & $\begin{array}{l}\text { Superposed and laterally continuous, trough cross-bedded, multi-storied sandstones in units } \\
\text { as thick as } 200 \text { feet. Exposures form conspicuous reddish-orange cliffs along Red Rim. }\end{array}$ \\
\hline & & & $\begin{array}{l}\text { lower } \\
\text { member }\end{array}$ & up to 2,950 & $\begin{array}{l}\text { Upper part consists of trough cross-bedded sandstones. Lower part consists of mudrocks. } \\
\text { Contains subbituminous coal beds. Intertongues with the underlying Fox Hills Sandstone }\end{array}$ \\
\hline & & $\begin{array}{l}\text { Fox } \\
\text { Hills } \\
\text { Sandstone }\end{array}$ & & up to 1,980 & $\begin{array}{l}\text { Orangish- to yellowish-gray massive, trough cross-bedded sandstones. Exposures may } \\
\text { locally form cliffs. Intertongues with the underlying Lewis Shale }\end{array}$ \\
\hline & & \multirow[t]{2}{*}{$\begin{array}{l}\text { Lewis } \\
\text { Shale }\end{array}$} & & up to 1,600 & $\begin{array}{l}\text { Dark gray, sandy marine shale that is poorly exposed and forms valleys. Lower part may } \\
\text { contain Dad Sandstone member and intertongues with Almond Formation. }\end{array}$ \\
\hline & & & $\begin{array}{l}\text { Dad SS } \\
\text { Member }\end{array}$ & $\begin{array}{l}0 \text { to } 600 \text { feet } \\
\text { thick }\end{array}$ & Thick turbidite sandstones \\
\hline & & \multirow{2}{*}{ 鱼 $\begin{array}{c}\text { Almond } \\
\text { Formation }\end{array}$} & $\begin{array}{l}\text { upper } \\
\text { member }\end{array}$ & up to 300 & Gray shale and sandstone, capped by mudrock. Contains subbituminous coal \\
\hline & & & $\begin{array}{l}\text { lower } \\
\text { member }\end{array}$ & up to 250 & Consists of sandstone, mudrock, and subbituminous coal beds. \\
\hline & & 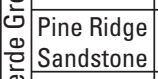 & & up to 100 & $\begin{array}{l}\text { Sandstone, carbonaceous siltstone, mudstone, and thin coal beds deposited in a fluvial } \\
\text { paleoenvironment. }\end{array}$ \\
\hline & & 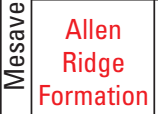 & & up to 1,400 & $\begin{array}{l}\text { Marginal marine to nonmarine depositional environments consisting of shaley mudstones, } \\
\text { sandstones, siltstones, mudstones, and coal beds. }\end{array}$ \\
\hline & & \begin{tabular}{|l|} 
Haystack \\
Mountains \\
Formation
\end{tabular} & & up to 950 & $\begin{array}{l}\text { Consists of alternating units of thick, laterally extensive sandstone and shale beds that } \\
\text { respectively form prominent cliffs and intervening slopes. }\end{array}$ \\
\hline
\end{tabular}

Coal-bearing units are indicated with red text.

Figure 9 (pages 40 and 41). A, Generalized stratigraphic column, showing age, units, description of units, and maximum thickness of units for the Little Snake River coal field and Red Desert assessment area, Wyoming; B, Generalized geologic cross-section showing the intertonguing relations of the Battle Spring, Wasatch, and Green River Formations because of lateral facies changes in the Little Snake River coal field and Red Desert assessment area, Greater Green River Basin, Wyoming. 
B

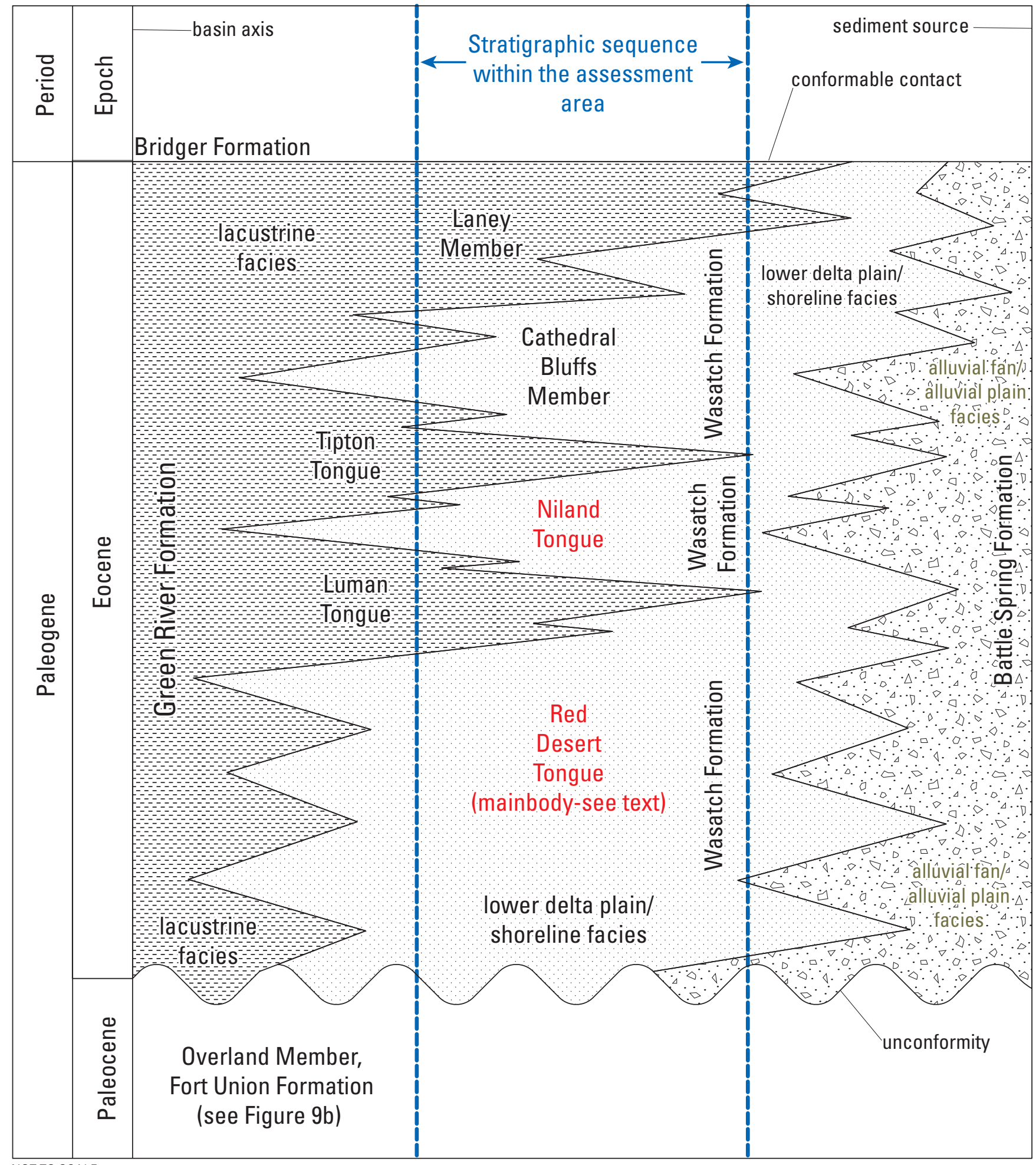

NOT TO SCALE

Coal-bearing units are indicated with red text.

Figure 9. - Continued 


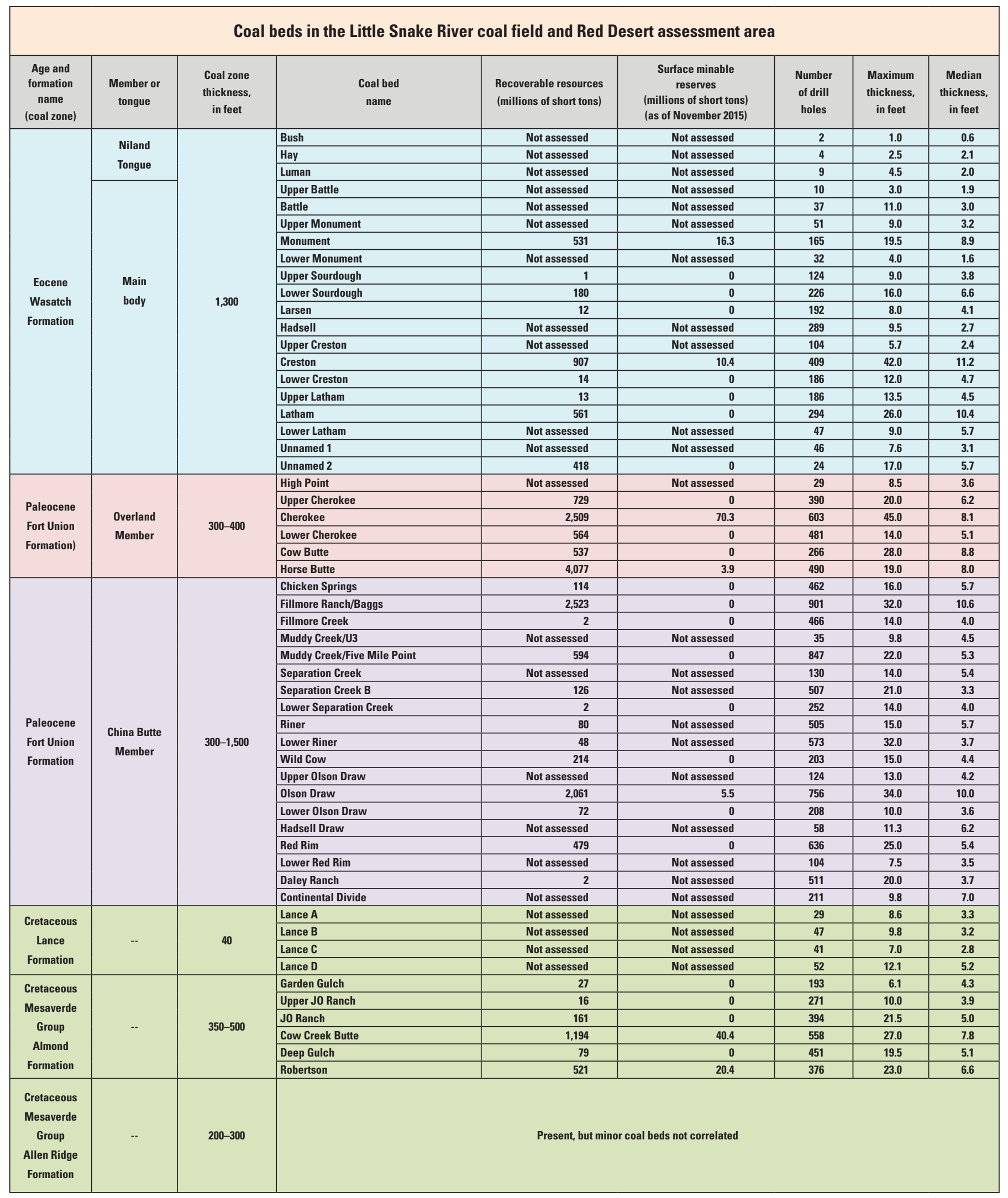

Figure 10. Stratigraphic column showing age, formation name, coal-bearing thickness, bed name, resources, reserves, number of drill holes, and maximum and median thicknesses of coal beds in the Little Snake River coal field and Red Desert assessment area, Greater Green River Basin, Wyoming. 


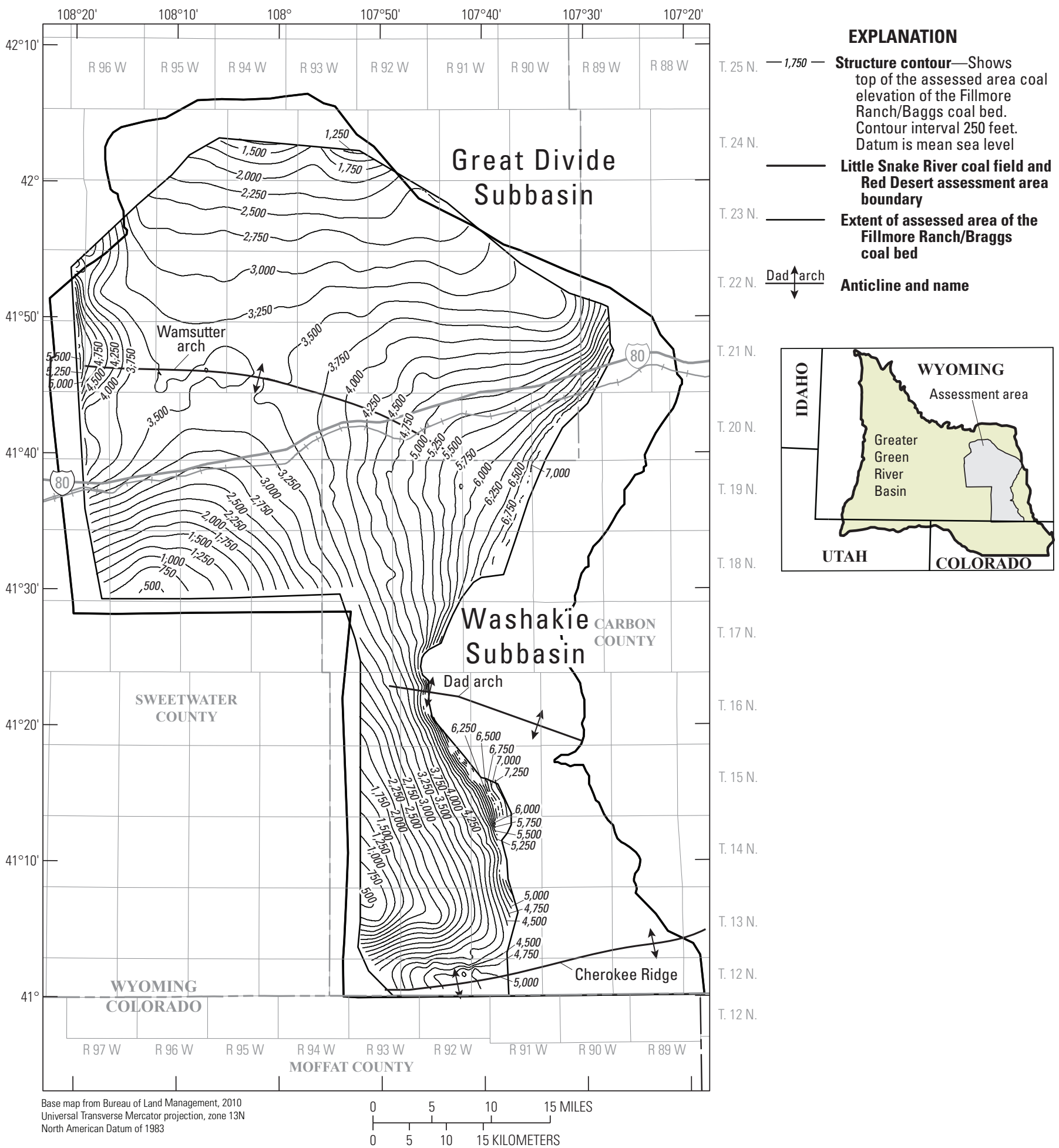

Figure 11. Structure contours drawn at the top of the Fillmore Ranch/Baggs coal bed within the Little Snake River coal field and Red Desert assessment area, Greater Green River Basin, Wyoming. 


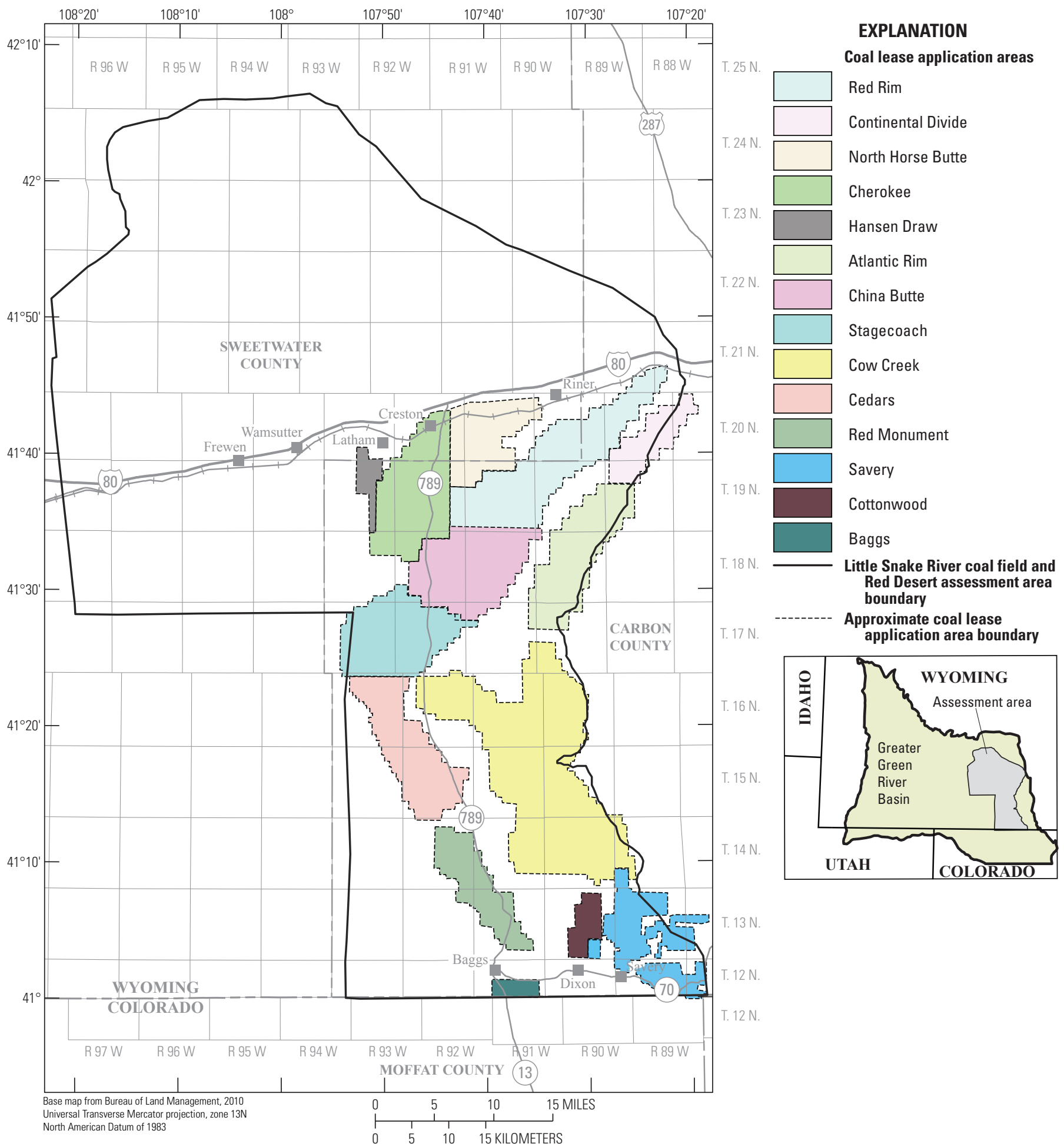

Figure 12. Approximate locations of coal lease application areas in the Little Snake River coal field and Red Desert assessment area, Greater Green River Basin, Wyoming. Modified from Bureau of Land Management and U.S. Geological Survey (1983). 


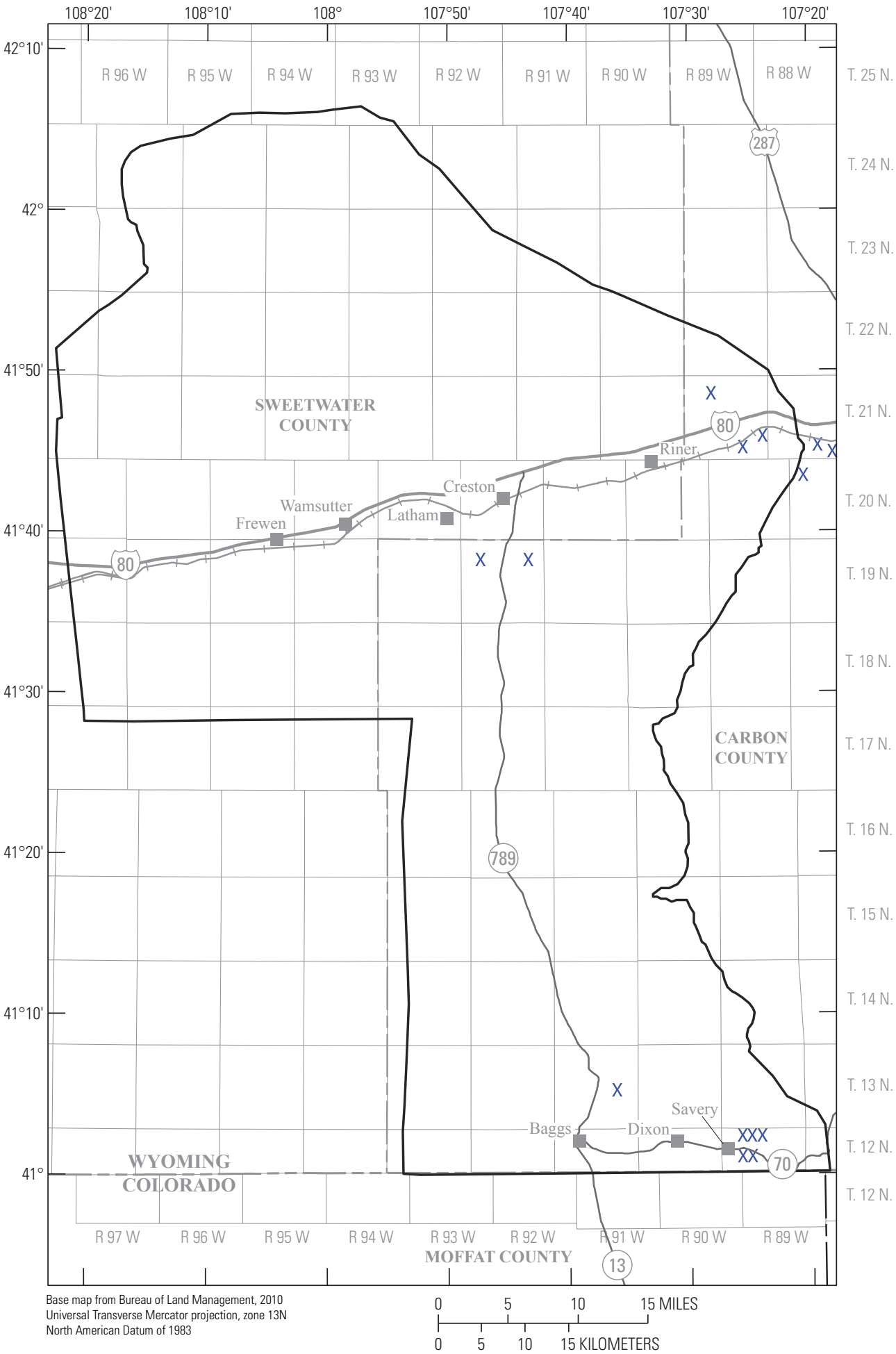

EXPLANATION

Little Snake River coal field and Red Desert assessment area boundary

$X \quad$ Approximate location of abandoned mine

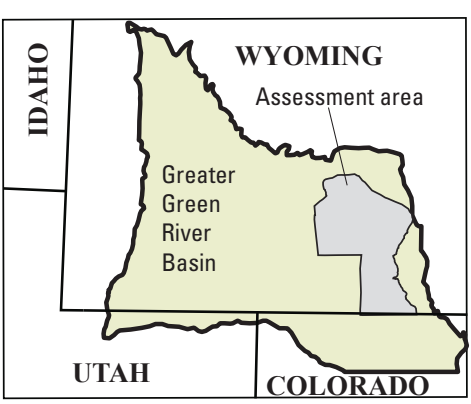

Figure 13. Approximate locations of abandoned mines in the Little Snake River coal field and Red Desert assessment area, Greater Green River Basin, Wyoming. 


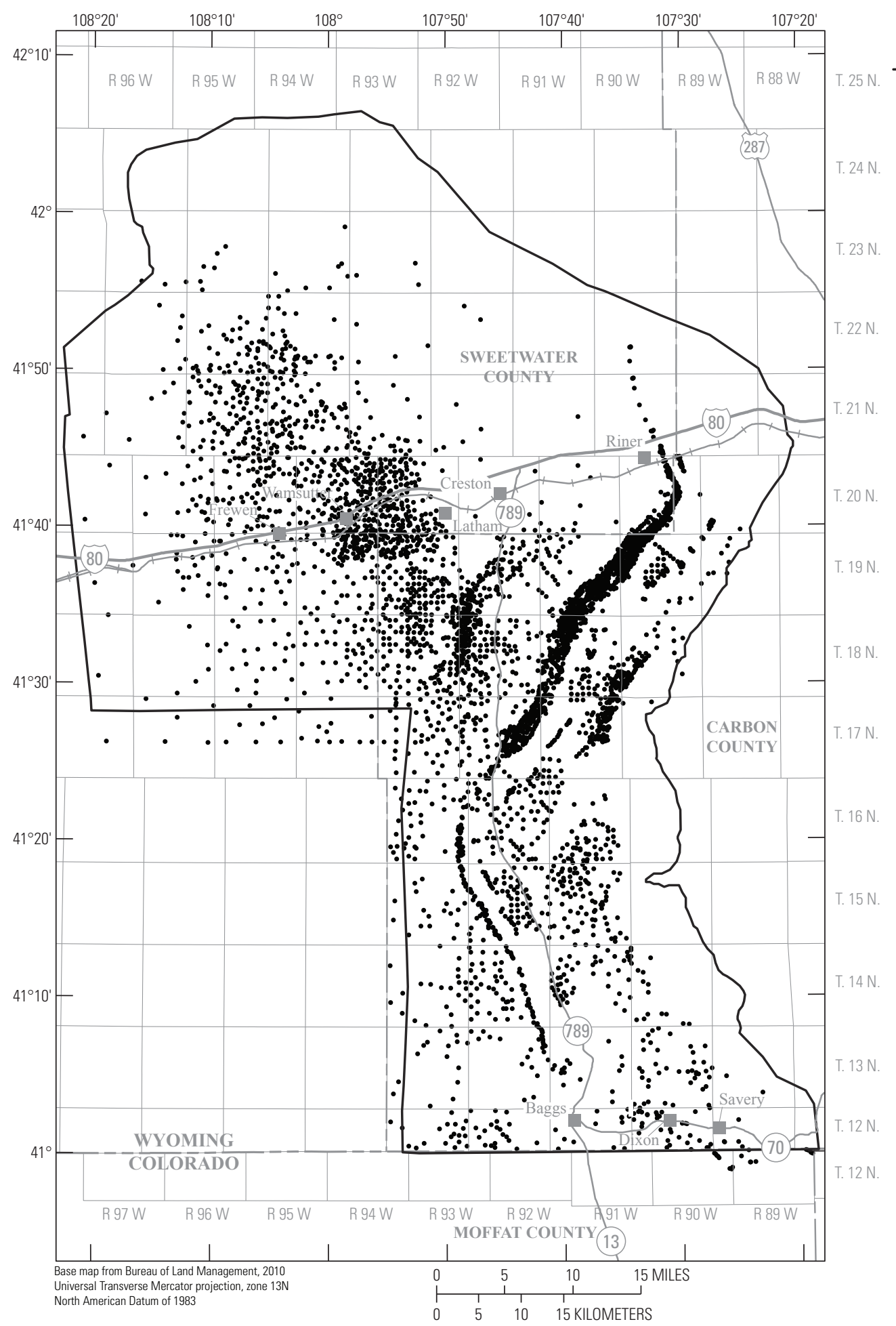

\section{EXPLANATION}

Little Snake River coal field and Red Desert assessment area boundary

Drill hole and measured section location

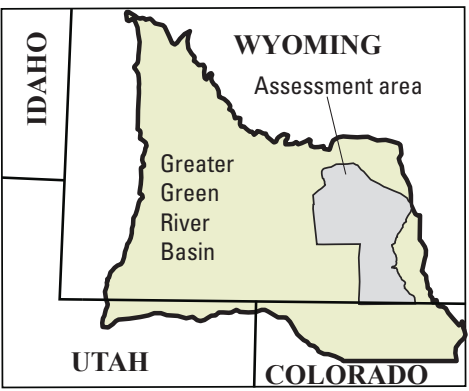

Figure 14. Drill hole locations in the Little Snake River coal field and Red Desert assessment area, Greater Green River Basin, Wyoming. 

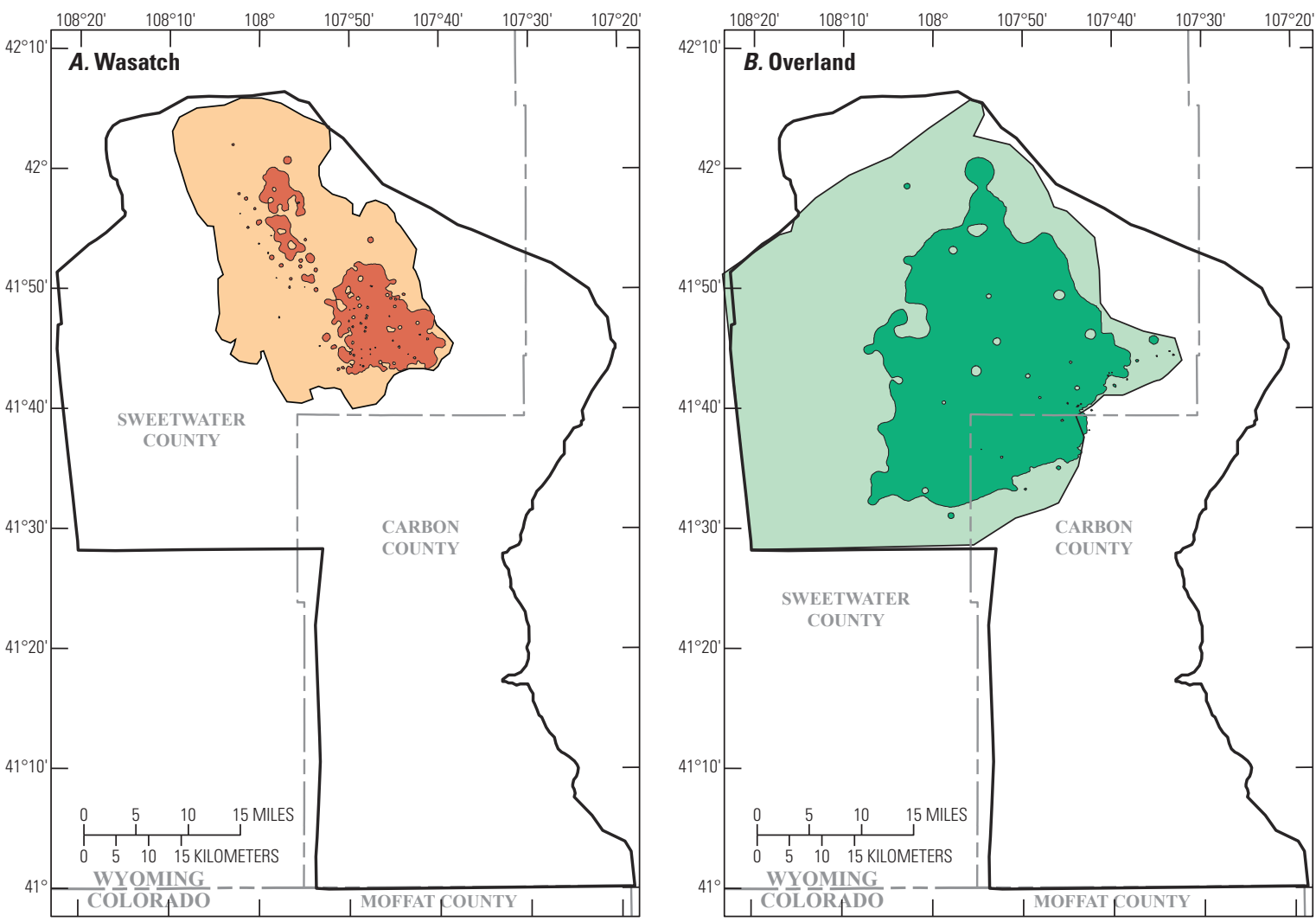

EXPLANATION

Coal zone

Wasatch

Overland

China Butte

Almond

Composite coal

thickness

greater than

25 feet

Wasatch

Overland

China Butte

Almond

Little Snake Rive coal field and Red Desert

assessment area boundary

Coal zone extent

boundary

Composite 25-feet thick coal

boundary
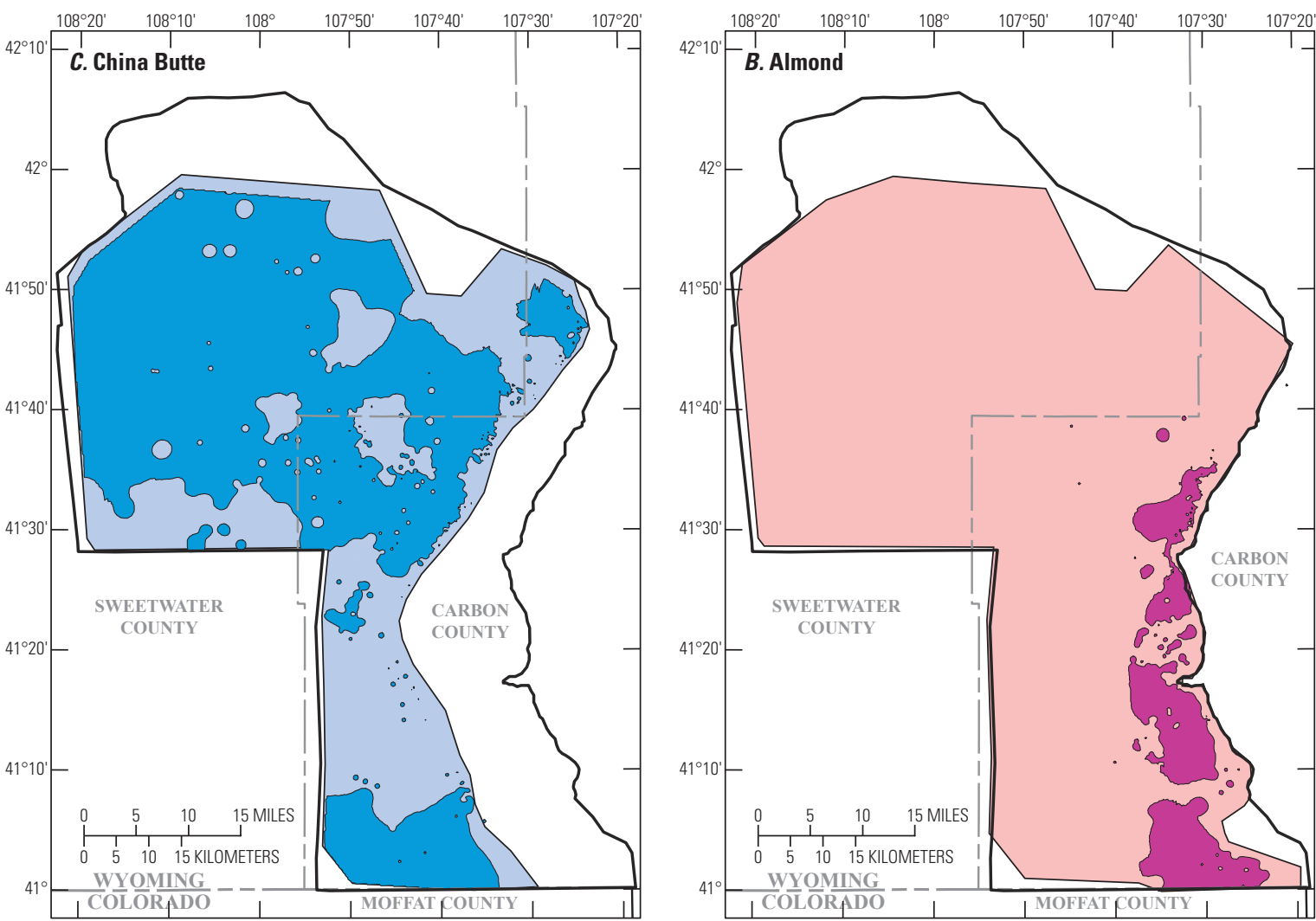

Base map from Bureau of Land

Management, 2010

.

projection, zone 13N

North American Datum of 1983

Figure 15. Coal zone extents and locations of deposition centers in the $A$, Wasatch, $B$, Overland, $C$, China Butte, and

$D$, Almond coal zones in the Little Snake River coal field and Red Desert assessment area, Greater Green River Basin, Wyoming. 


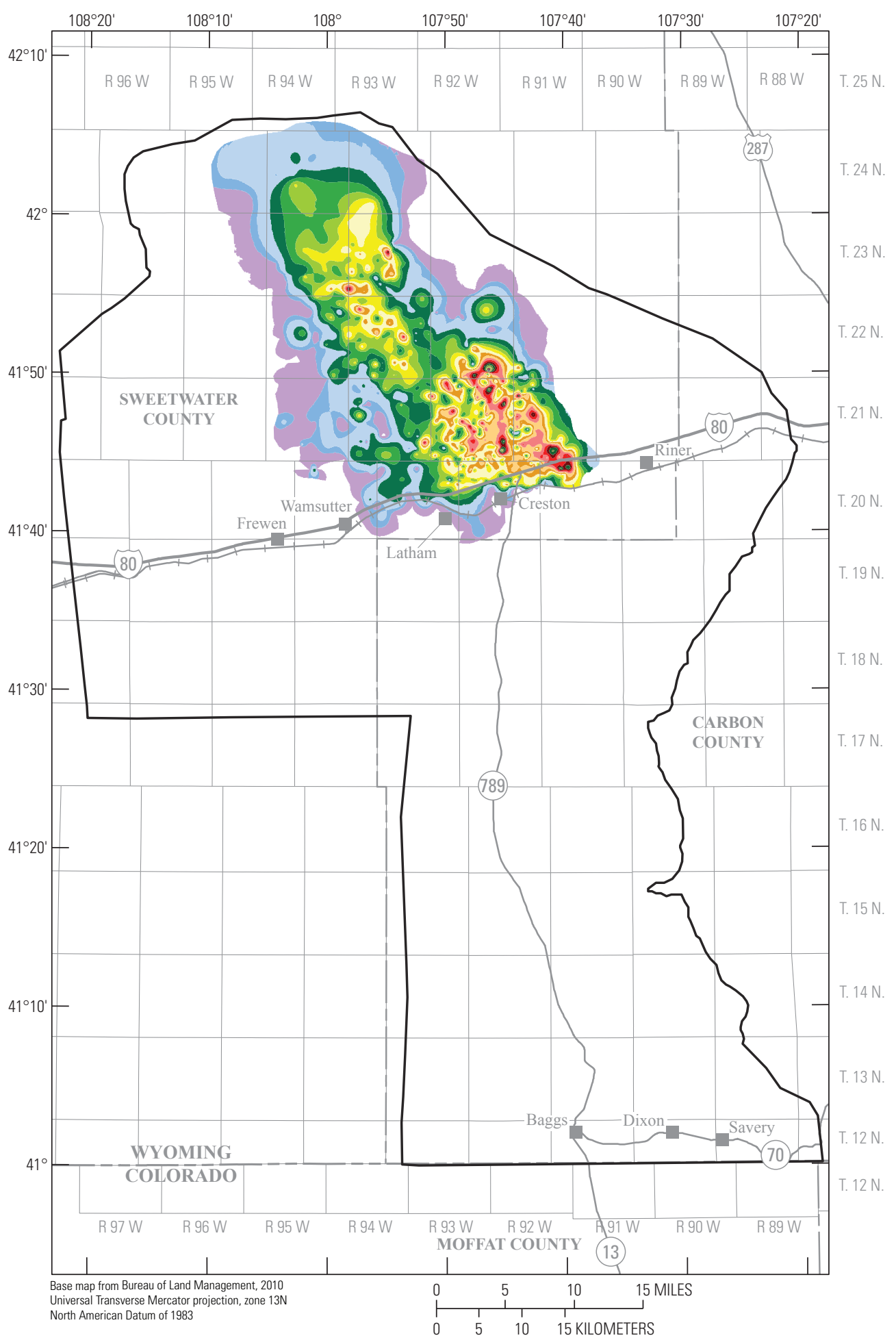

\section{EXPLANATION}

Wasatch coal zone total coal isopach, in feet

Greater than 80

75 to 80

70 to 75

65 to 70

60 to 65

55 to 60

50 to 55

45 to 50

40 to 45

35 to 40

30 to 35

25 to 30

20 to 25

15 to 20

10 to 15

5 to 10

3 to 5

0 to 3

Little Snake River coal field and Red Desert assessment area boundary

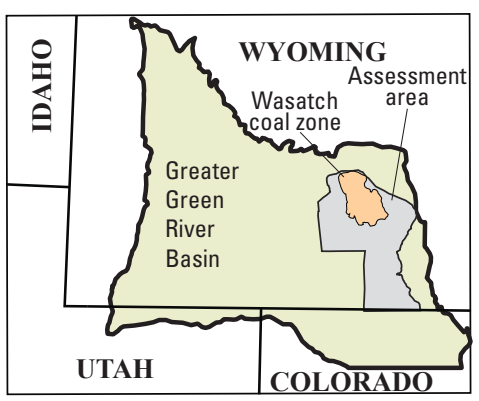

Figure 16. Composite thickness of all coal beds in the Wasatch coal zone within the Little Snake River coal field and Red Desert assessment area, Greater Green River Basin, Wyoming. 


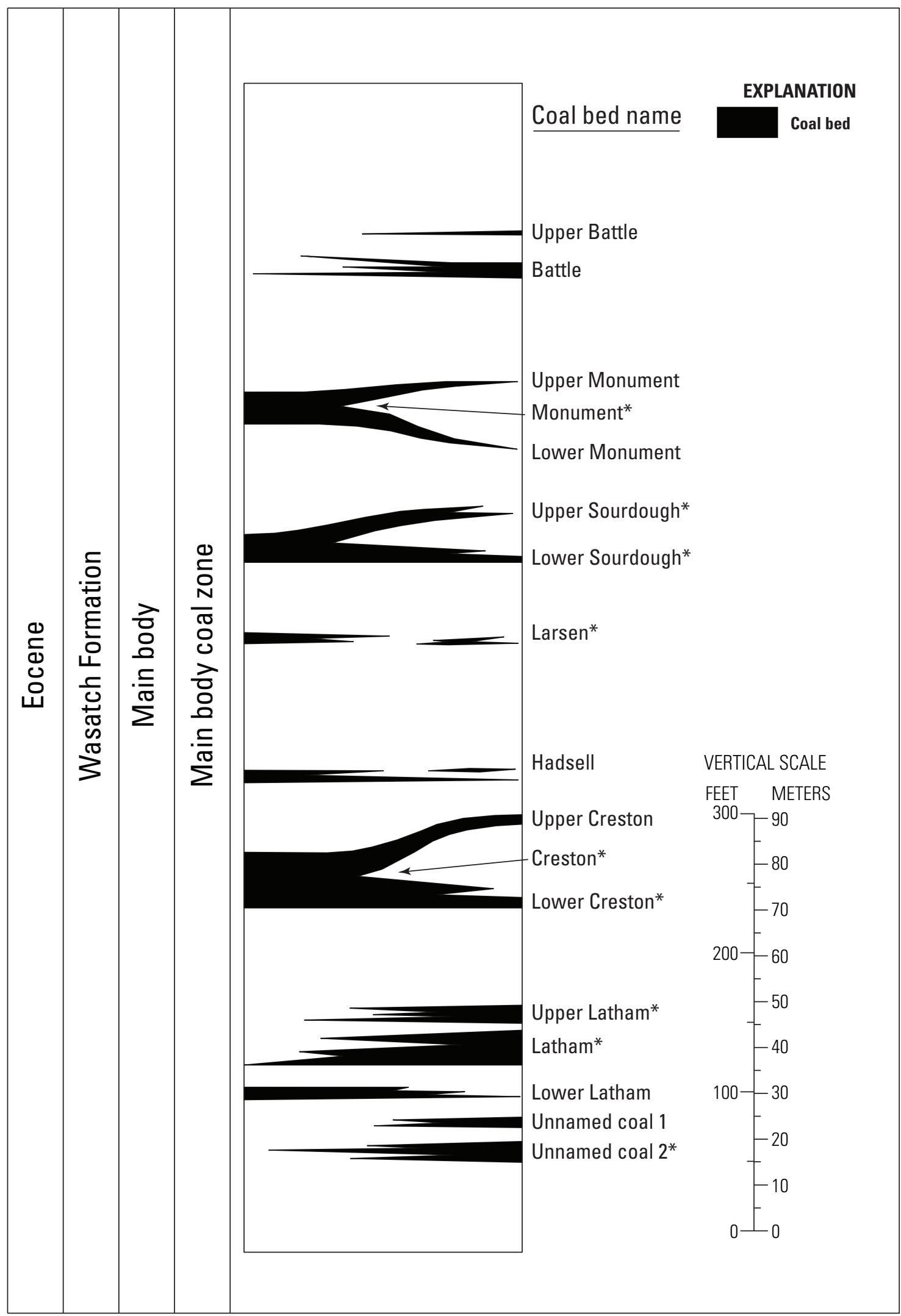

Figure 17. Coal beds in the Wasatch Formation coal zone in the Little Snake River coal field and Red Desert assessment area, Greater Green River Basin, Wyoming. Asterisk indicates that resources were calculated for bed. Cross section $A-A^{\prime}$ showing approximate subsurface distribution of coal beds in the Wasatch Formation in the Little Snake River coal field and Red Desert assessment area, Greater Green River Basin, Wyoming. 


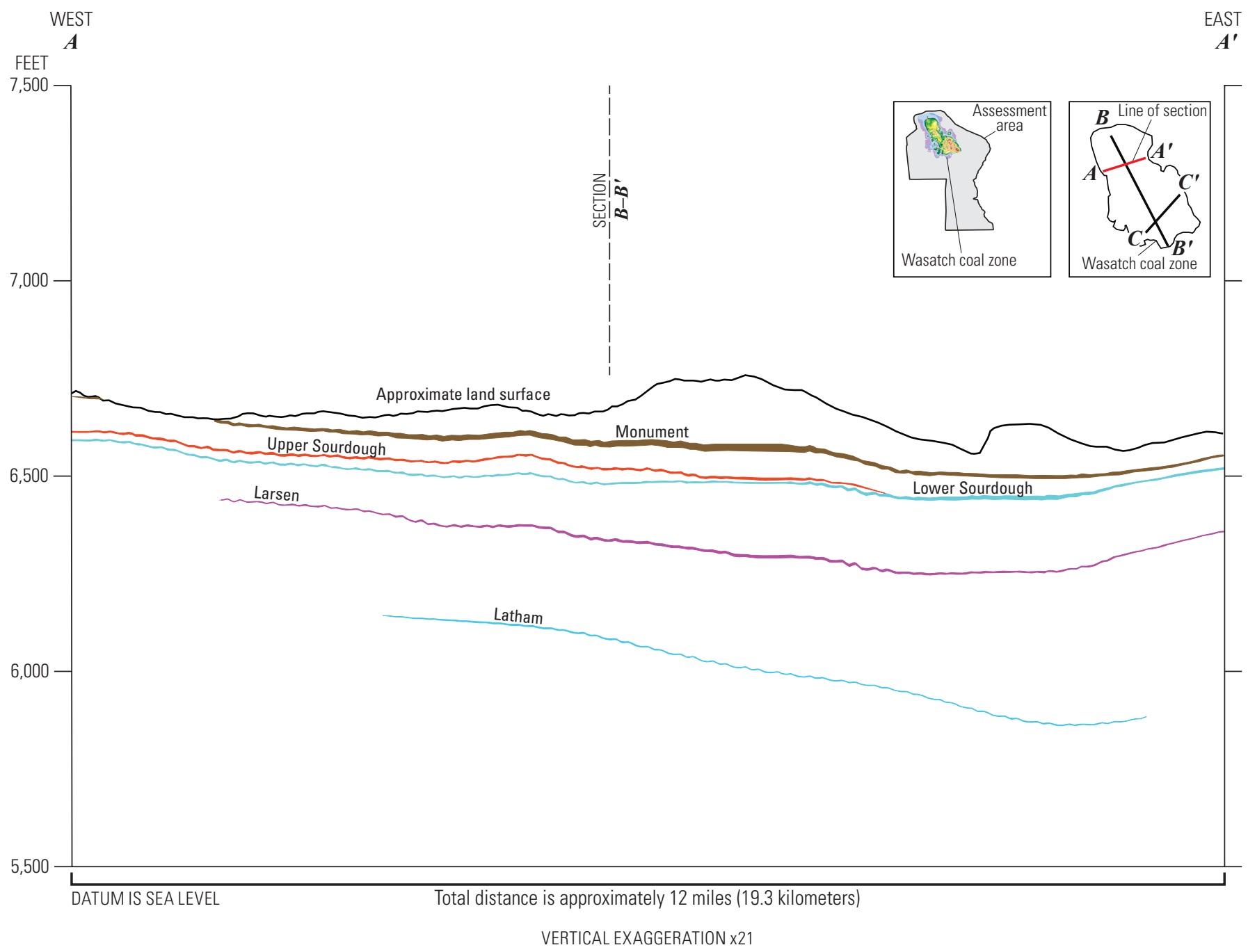

Figure 18. West-east cross section $A-A^{\prime}$ showing approximate subsurface distribution of Paleogene coal zones in the Little Snake River coal field and Red Desert assessment area Greater Green River Basin, Wyoming. 


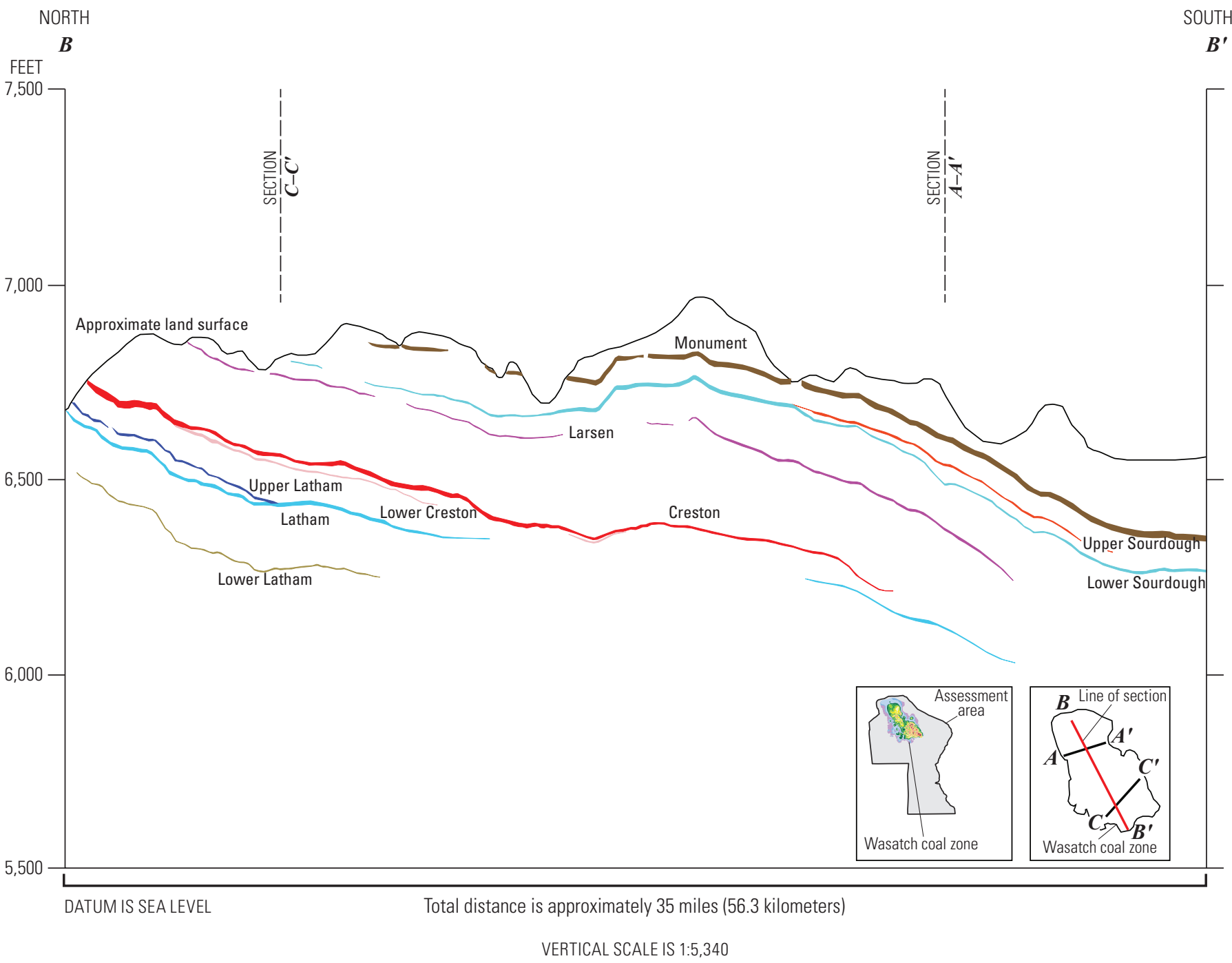

Figure 19. Cross section $B-B^{\prime}$ showing approximate subsurface distribution of coal beds in the Wasatch Formation in the Little Snake River coal field and Red Desert assessment area, Greater Green River Basin, Wyoming. 


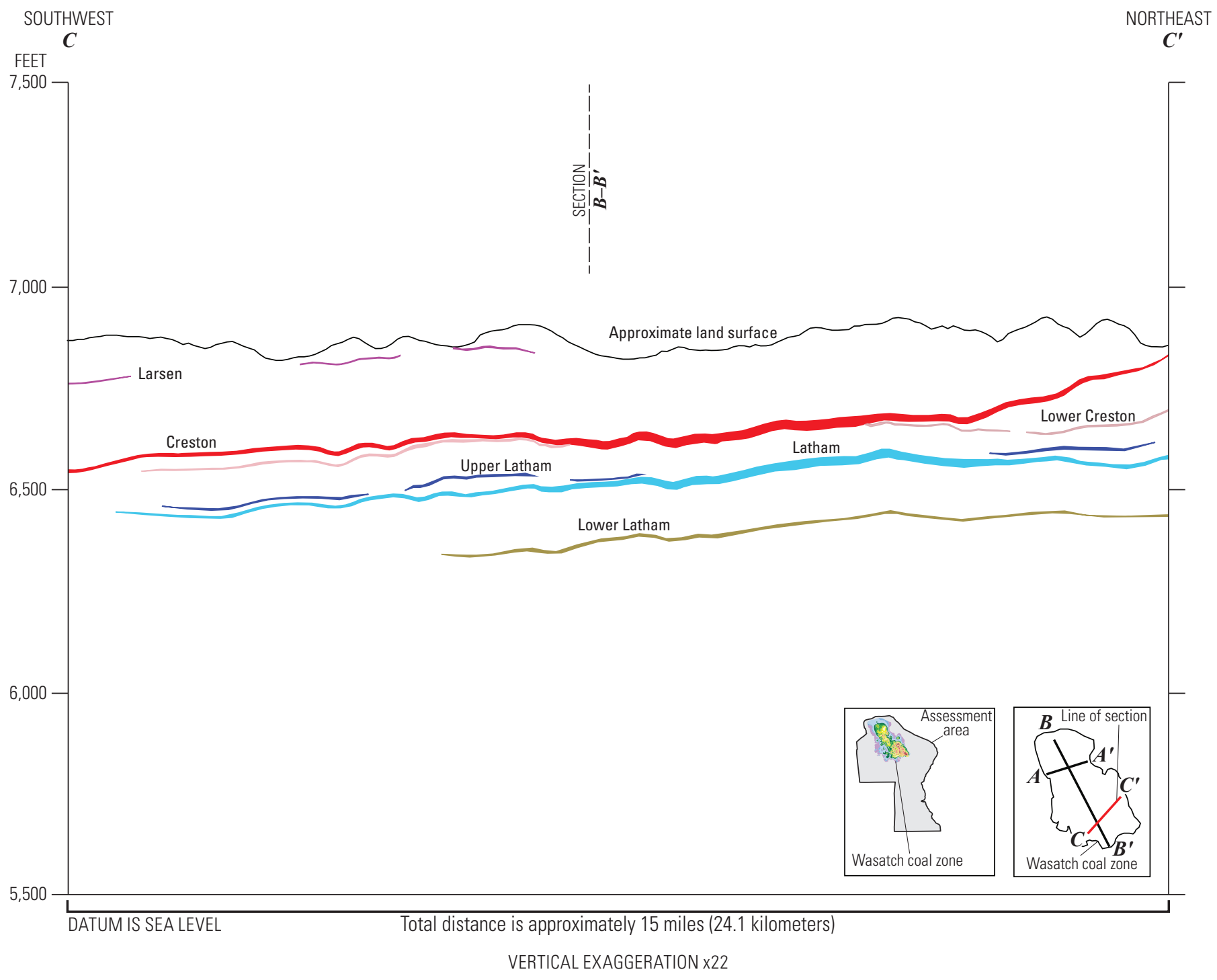

Figure 20. Cross section $C-C^{\prime}$ showing approximate subsurface distribution of coal beds in the Wasatch Formation in the Little Snake River coal field and Red Desert assessment area, Greater Green River Basin, Wyoming. 


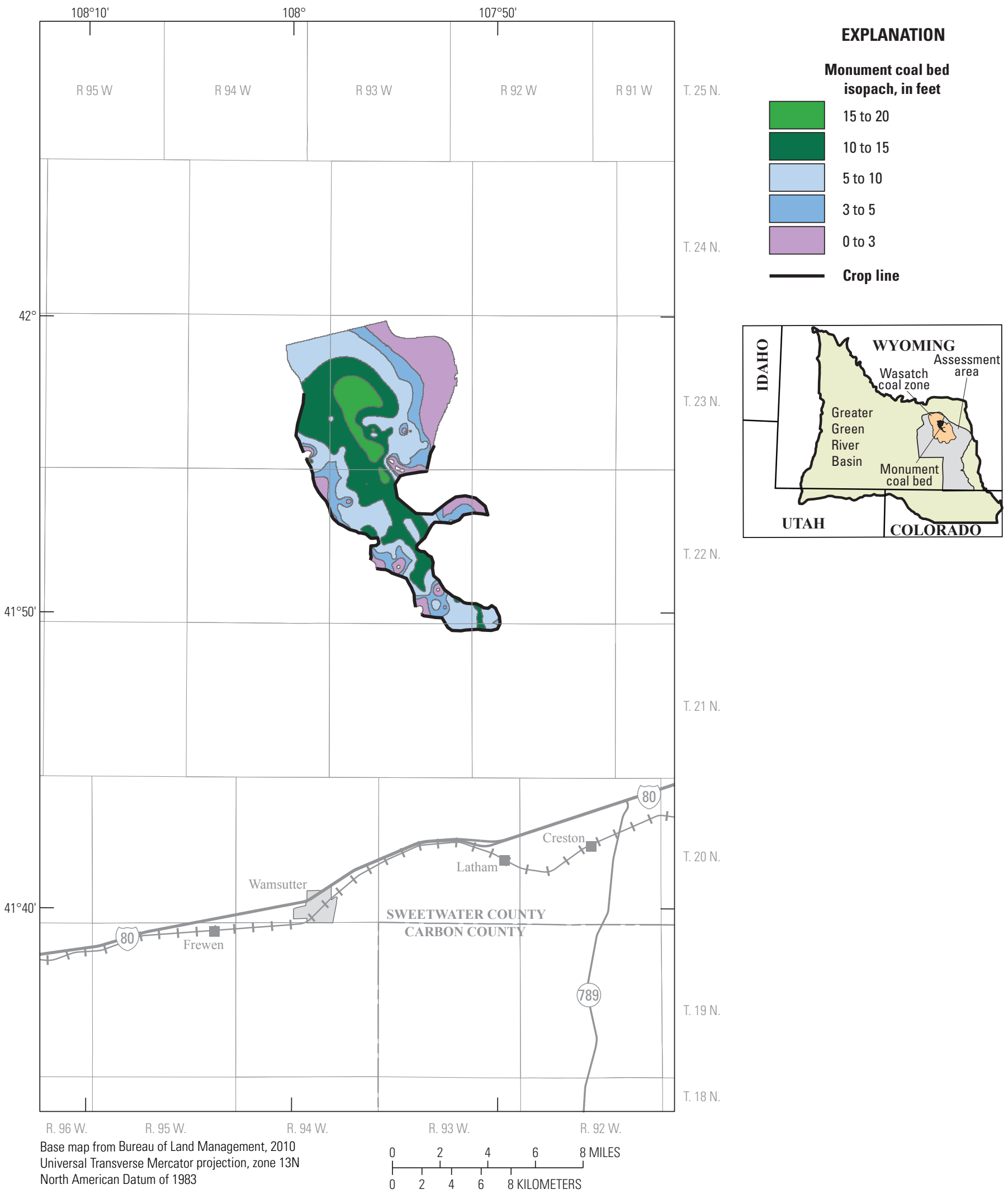

Figure 21. Monument coal bed showing extent of coal within the Little Snake River coal field and Red Desert assessment area, Greater Green River Basin, Wyoming. 


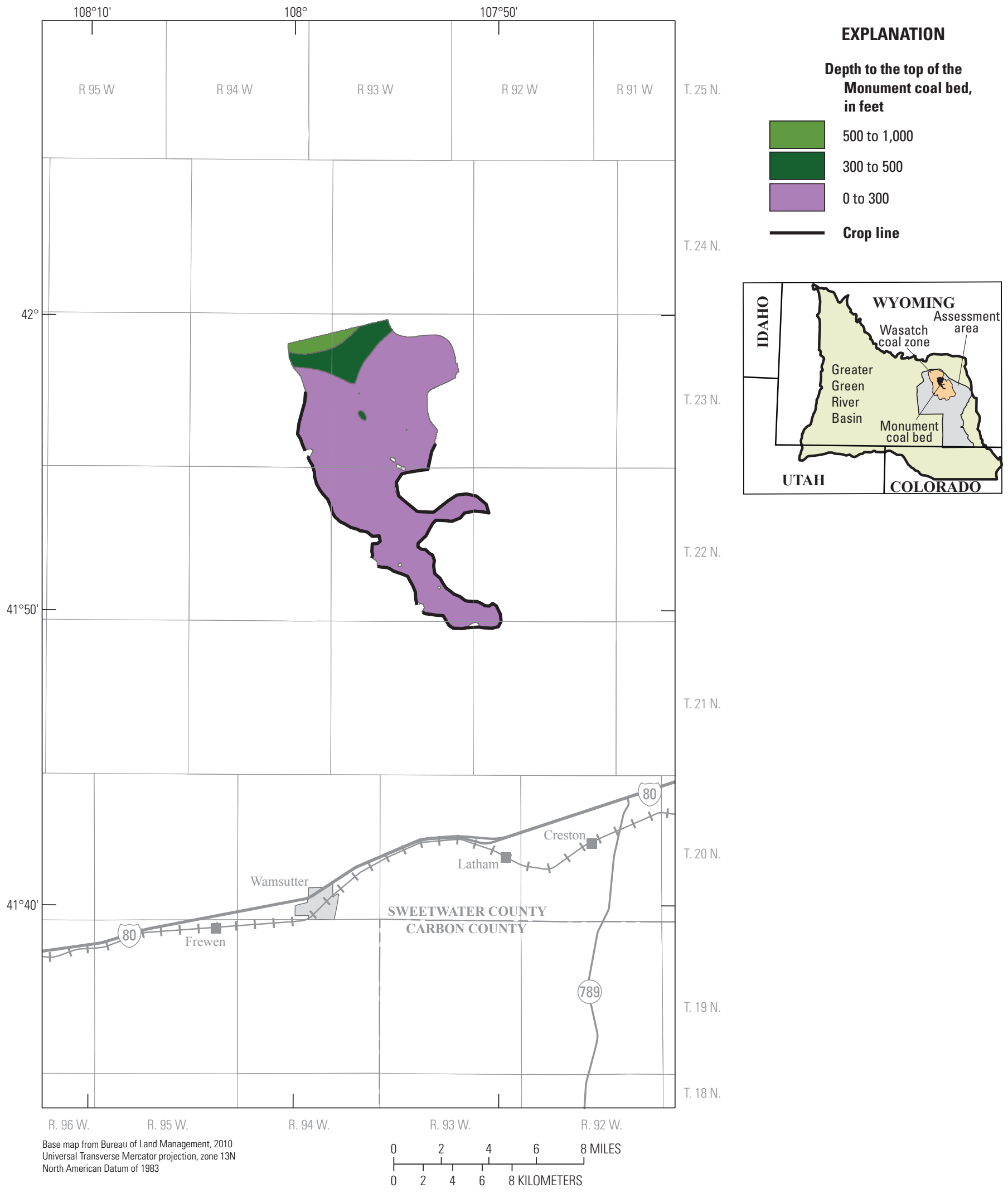

Figure 22. Depth to the top of the Monument coal bed within the Little Snake River coal field and Red Desert assessment area, Greater Green River Basin, Wyoming. 


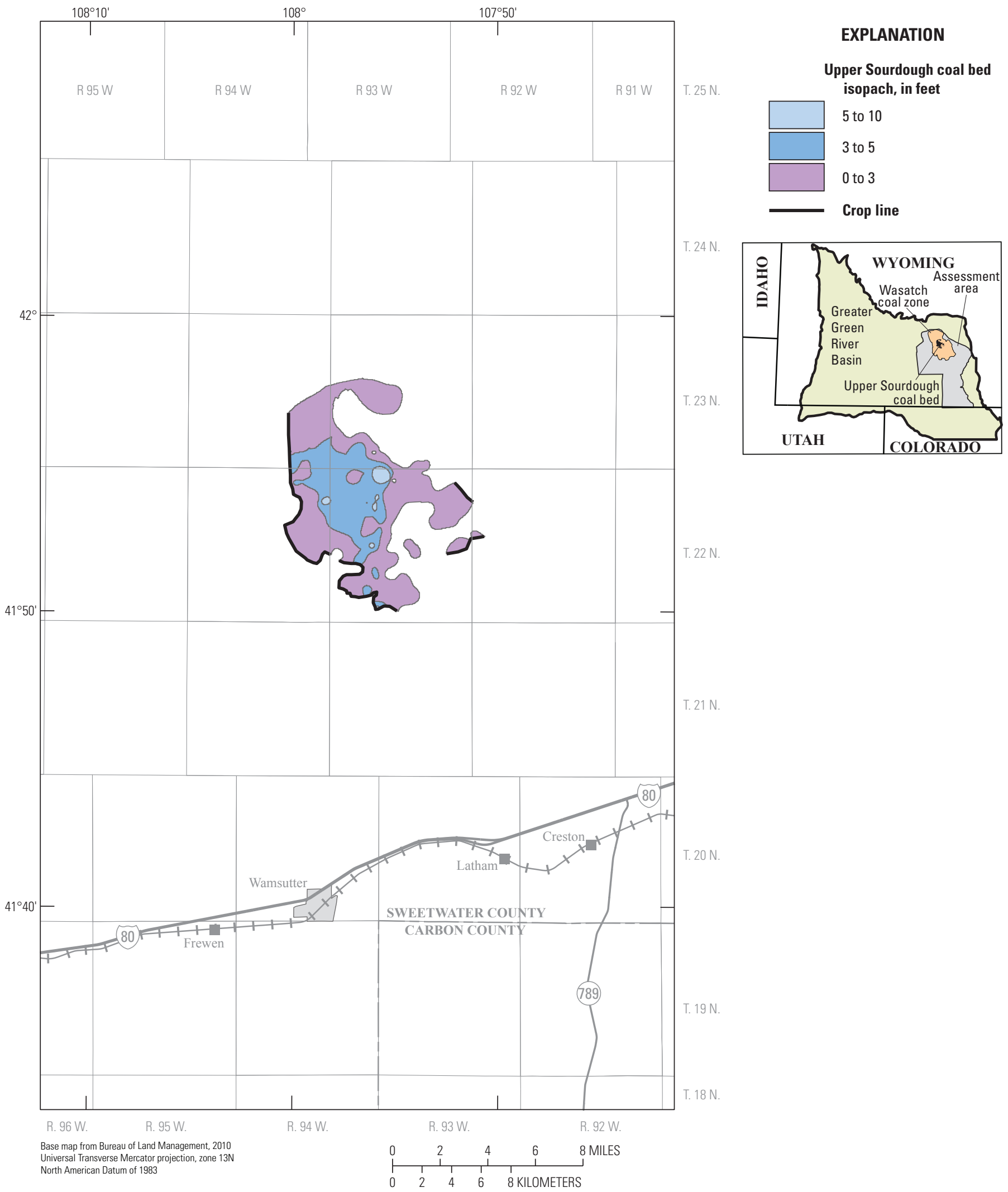

Figure 23. Upper Sourdough coal bed showing extent of coal within the Little Snake River coal field and Red Desert assessment area, Greater Green River Basin, Wyoming. 


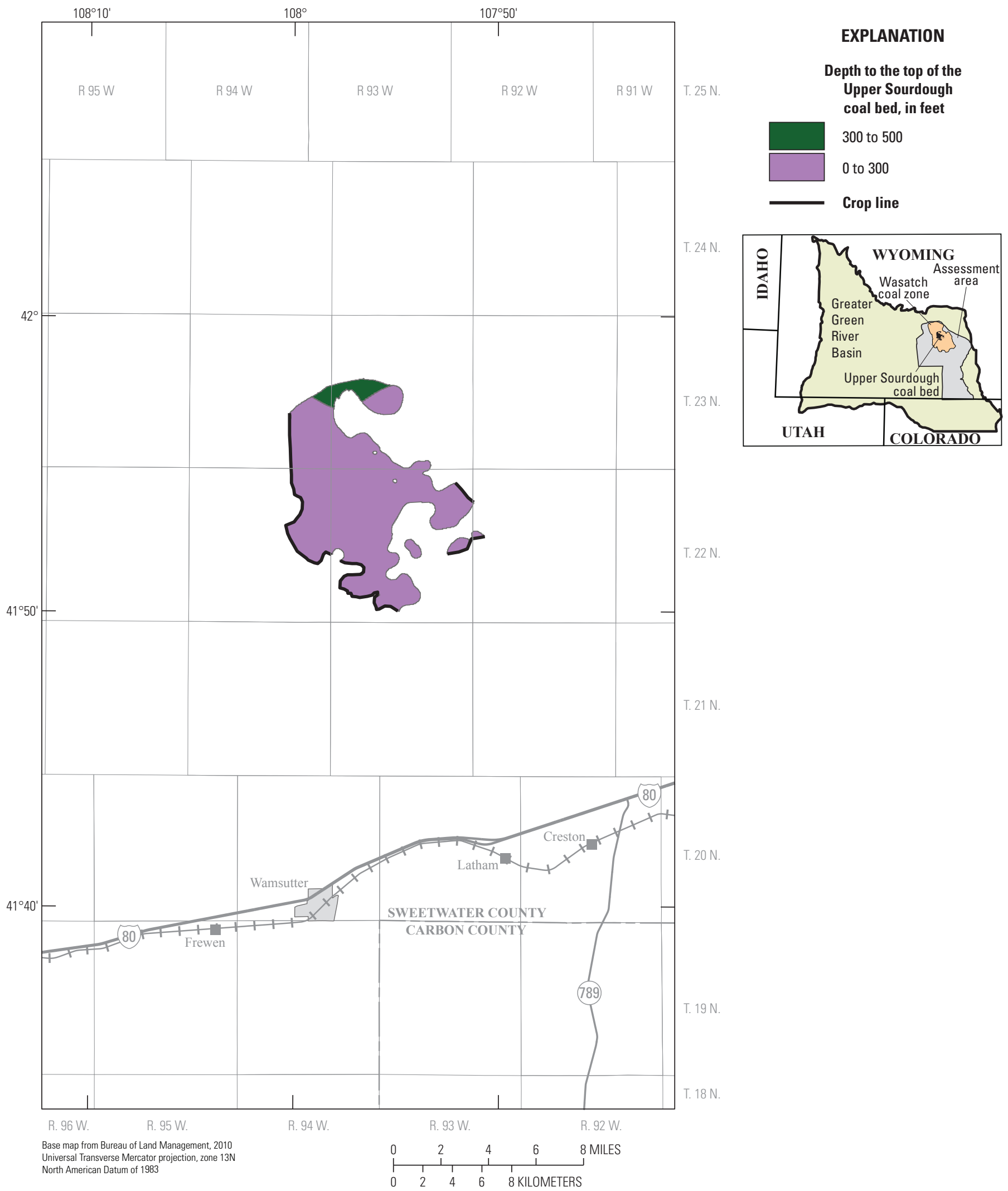

Figure 24. Depth to the top of the Upper Sourdough coal bed within the Little Snake River coal field and Red Desert assessment area, Greater Green River Basin, Wyoming. 


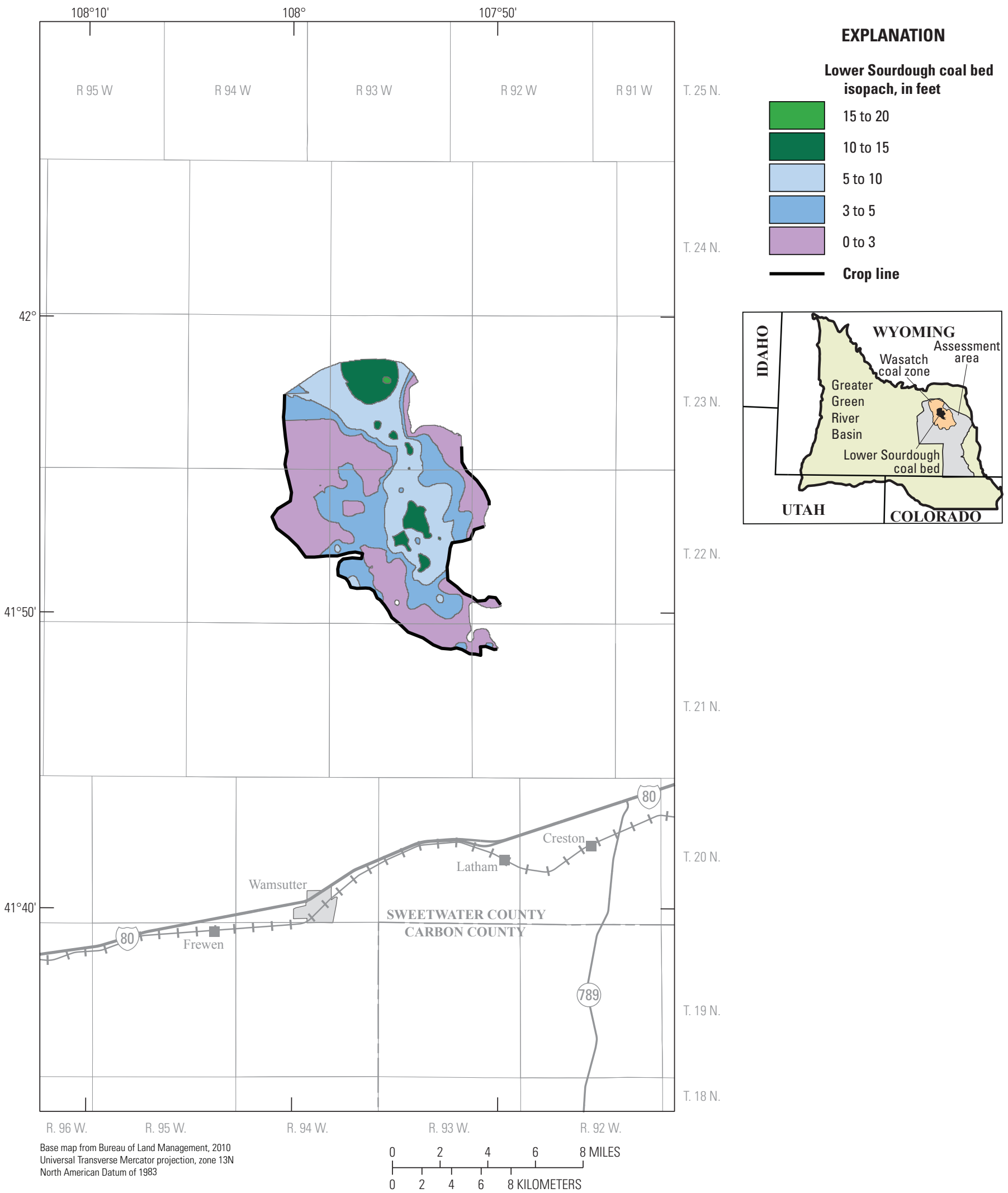

Figure 25. Lower Sourdough coal bed showing extent of coal within the Little Snake River coal field and Red Desert assessment area, Greater Green River Basin, Wyoming. 


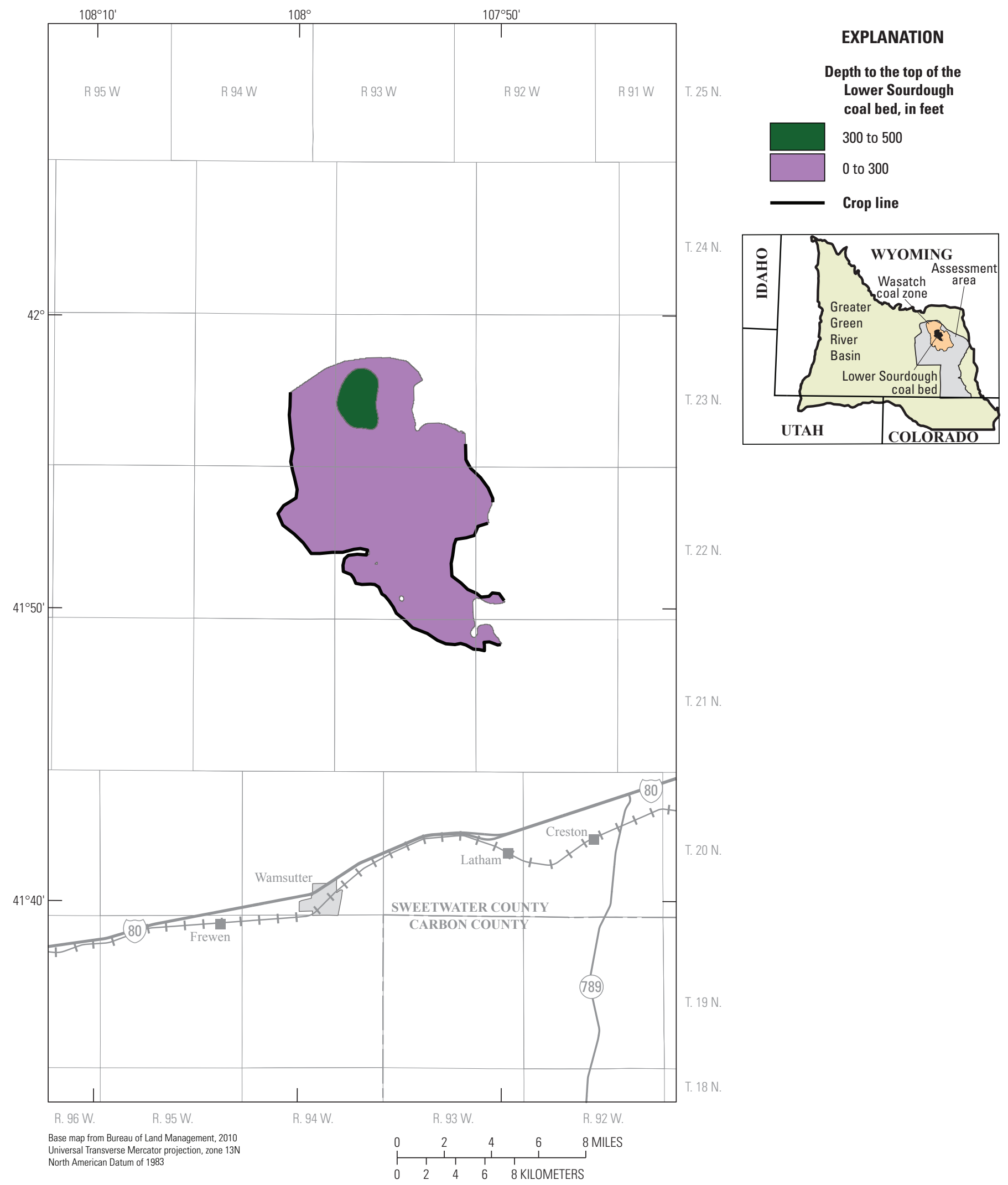

Figure 26. Depth to the top of the Lower Sourdough coal bed within the Little Snake River coal field and Red Desert assessment area, Greater Green River Basin, Wyoming. 


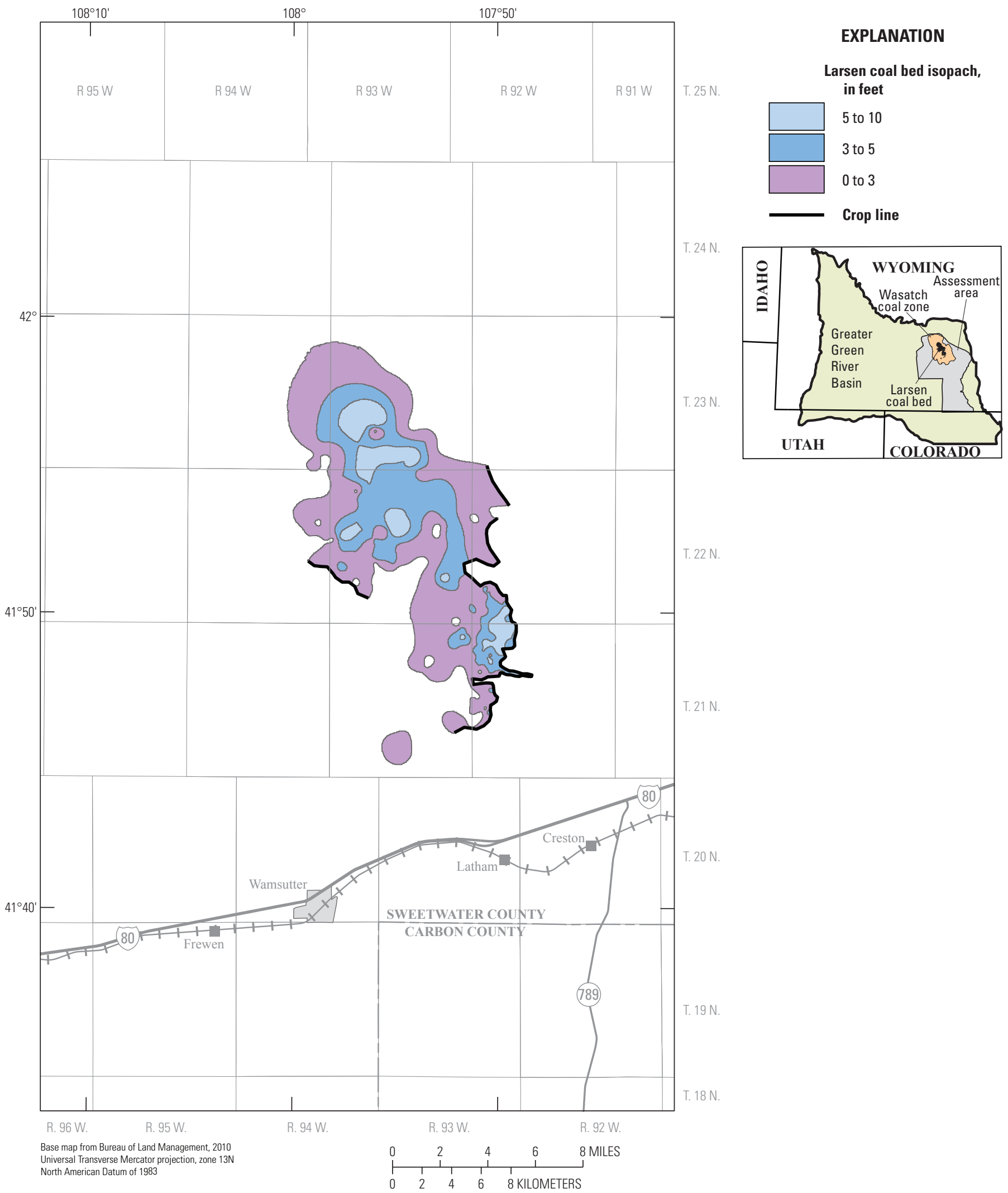

Figure 27. Larsen coal bed showing extent of coal within the Little Snake River coal field and Red Desert assessment area, Greater Green River Basin, Wyoming. 


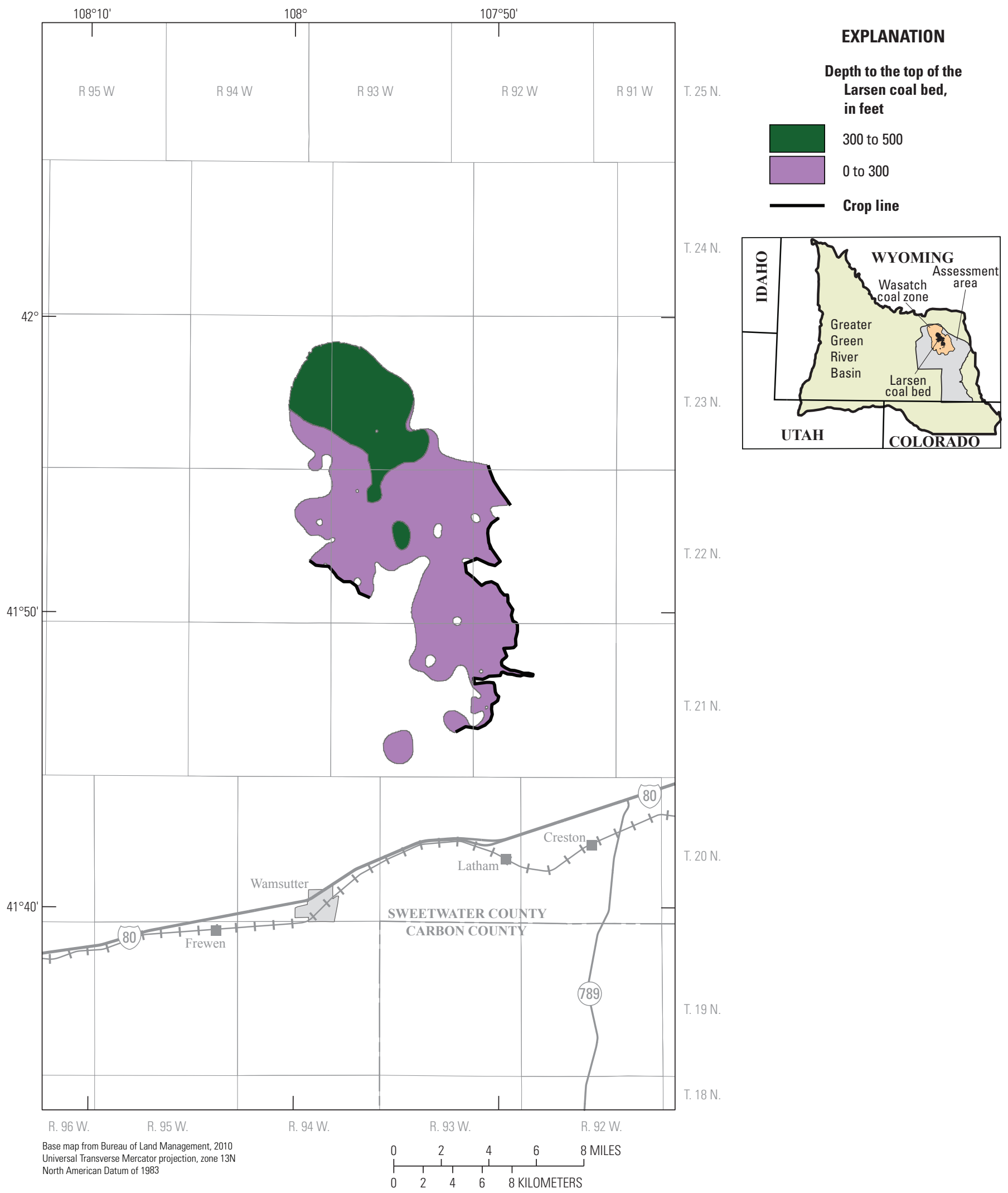

Figure 28. Depth to the top of the Larsen coal bed within the Little Snake River coal field and Red Desert assessment area, Greater Green River Basin, Wyoming. 


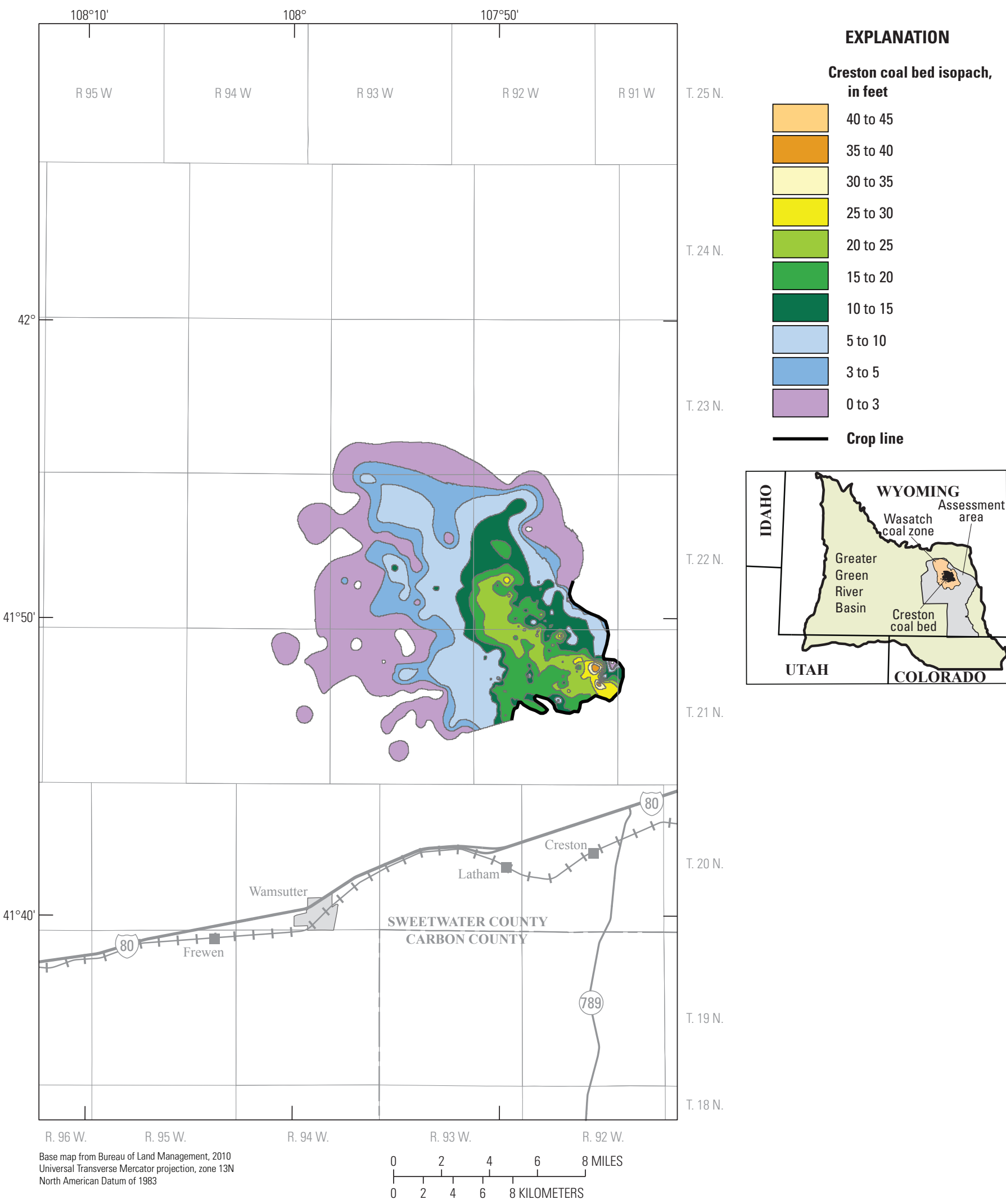

Figure 29. Creston coal bed showing extent of coal within the Little Snake River coal field and Red Desert assessment area, Greater Green River Basin, Wyoming. 


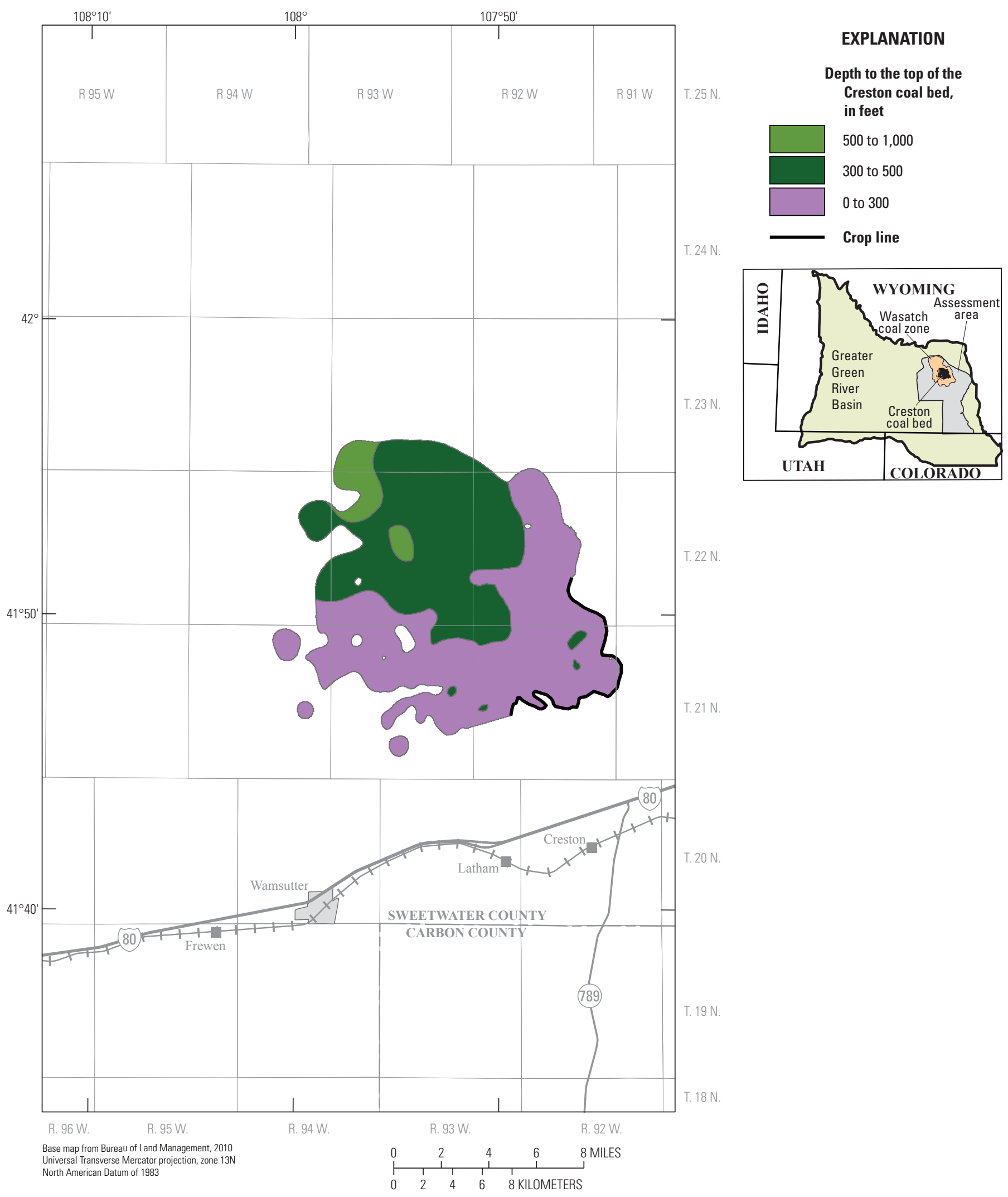

Figure 30. Depth to the top of the Creston coal bed within the Little Snake River coal field and Red Desert assessment area, Greater Green River Basin, Wyoming. 


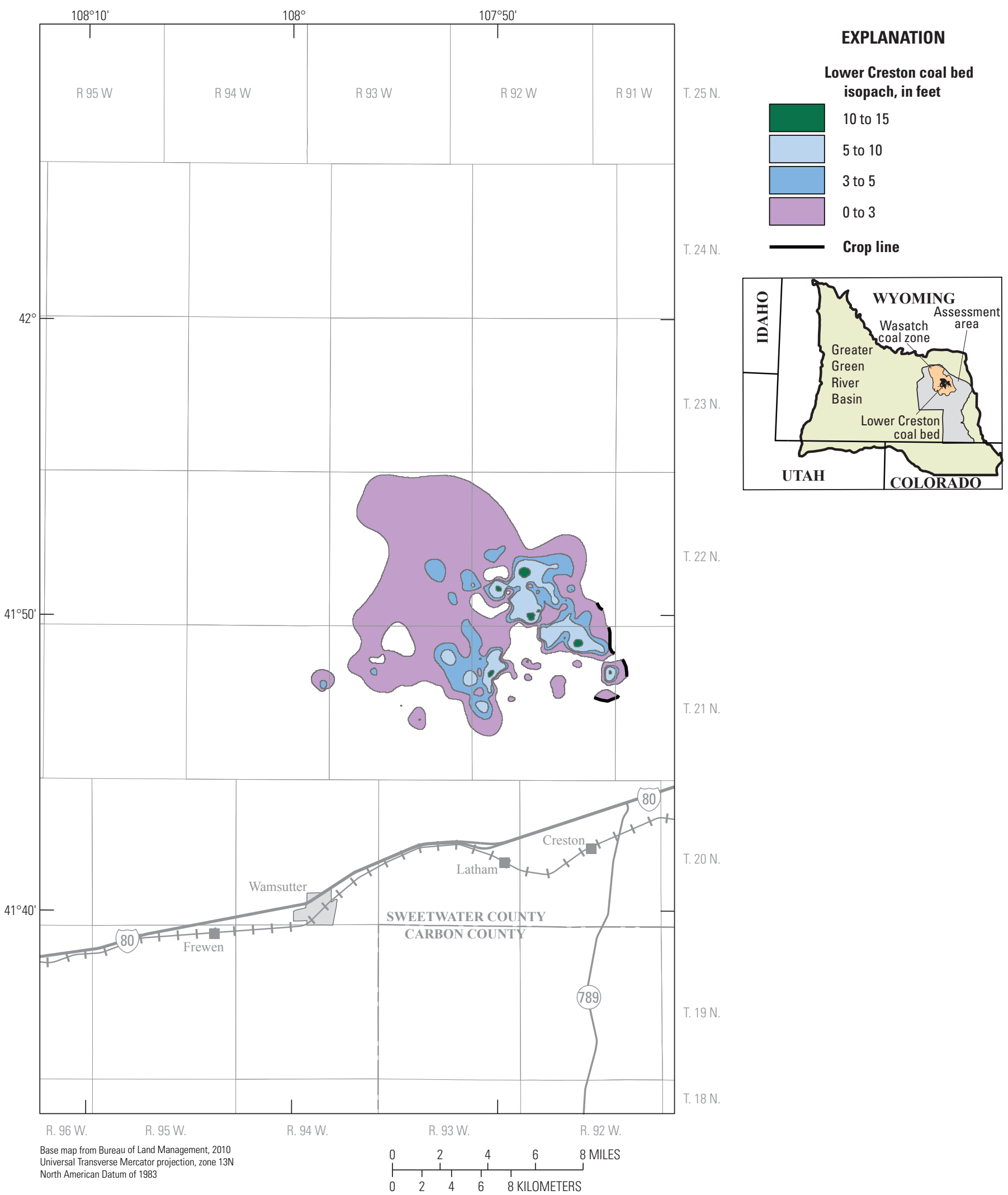

Figure 31. Lower Creston coal bed showing extent of coal within the Little Snake River coal field and Red Desert assessment area, Greater Green River Basin, Wyoming. 


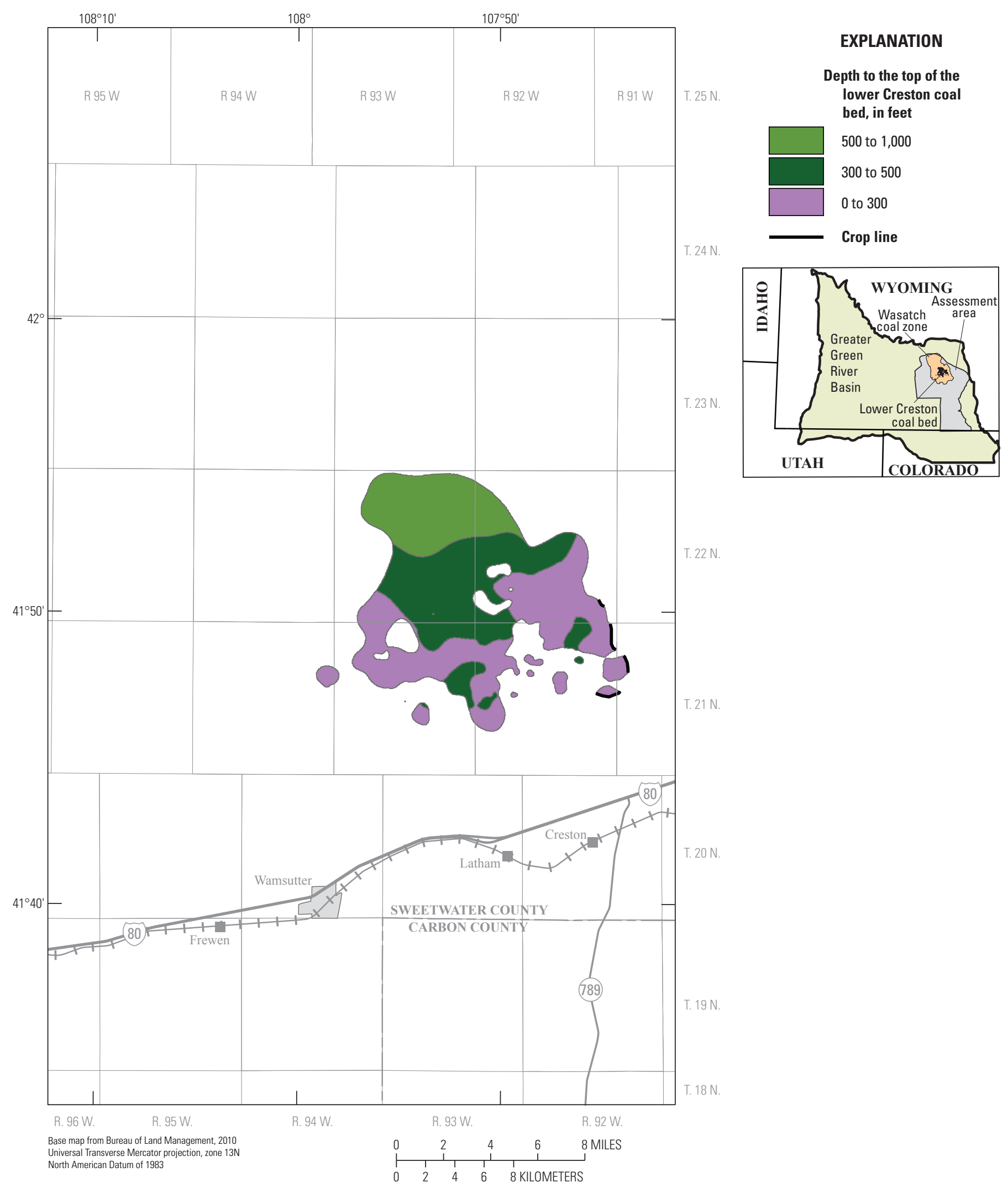

Figure 32. Depth to the top of the Lower Creston coal bed within the Little Snake River coal field and Red Desert assessment area, Greater Green River Basin, Wyoming. 


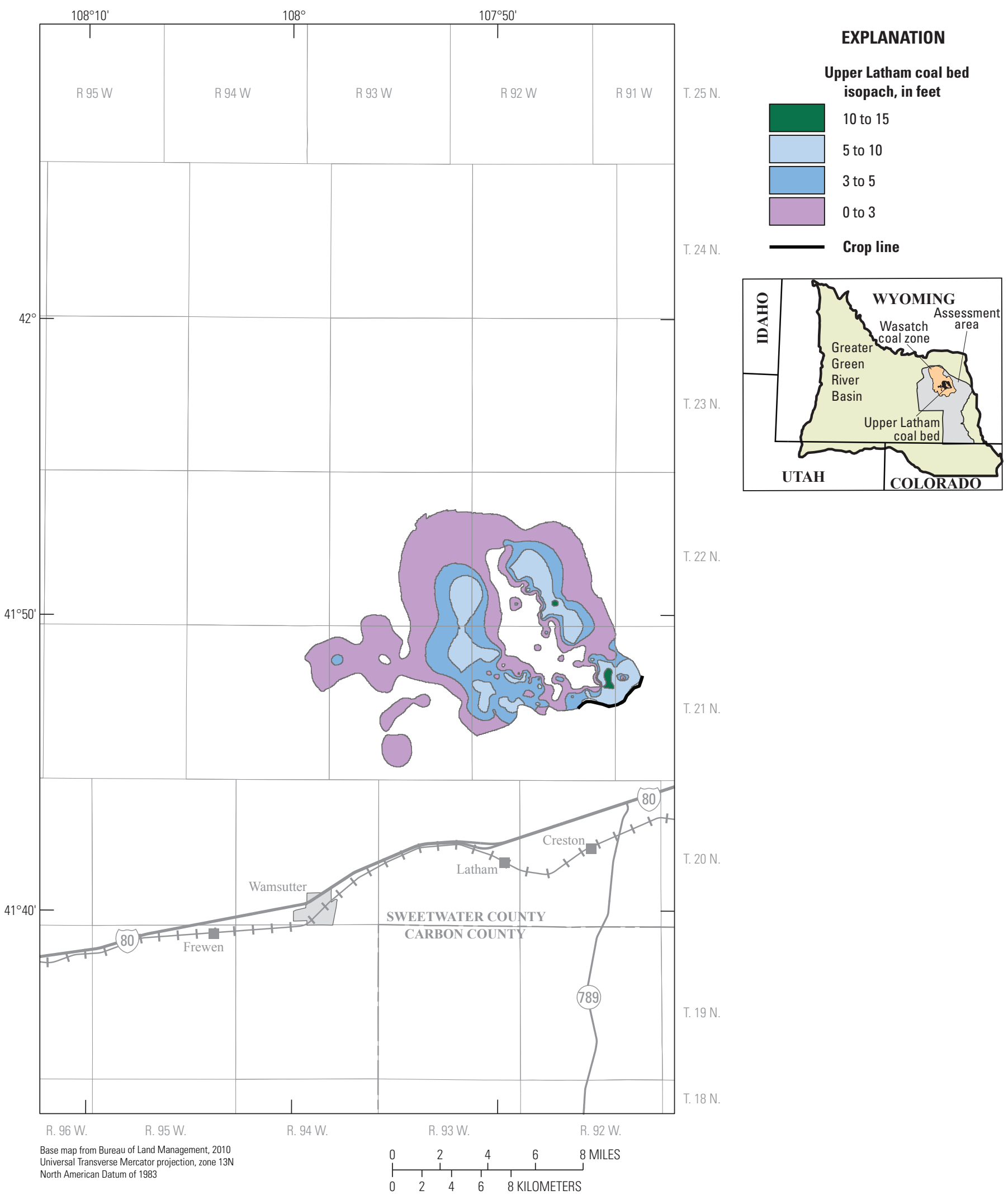

Figure 33. Upper Latham coal bed showing extent of coal within the Little Snake River coal field and Red Desert assessment area, Greater Green River Basin, Wyoming. 


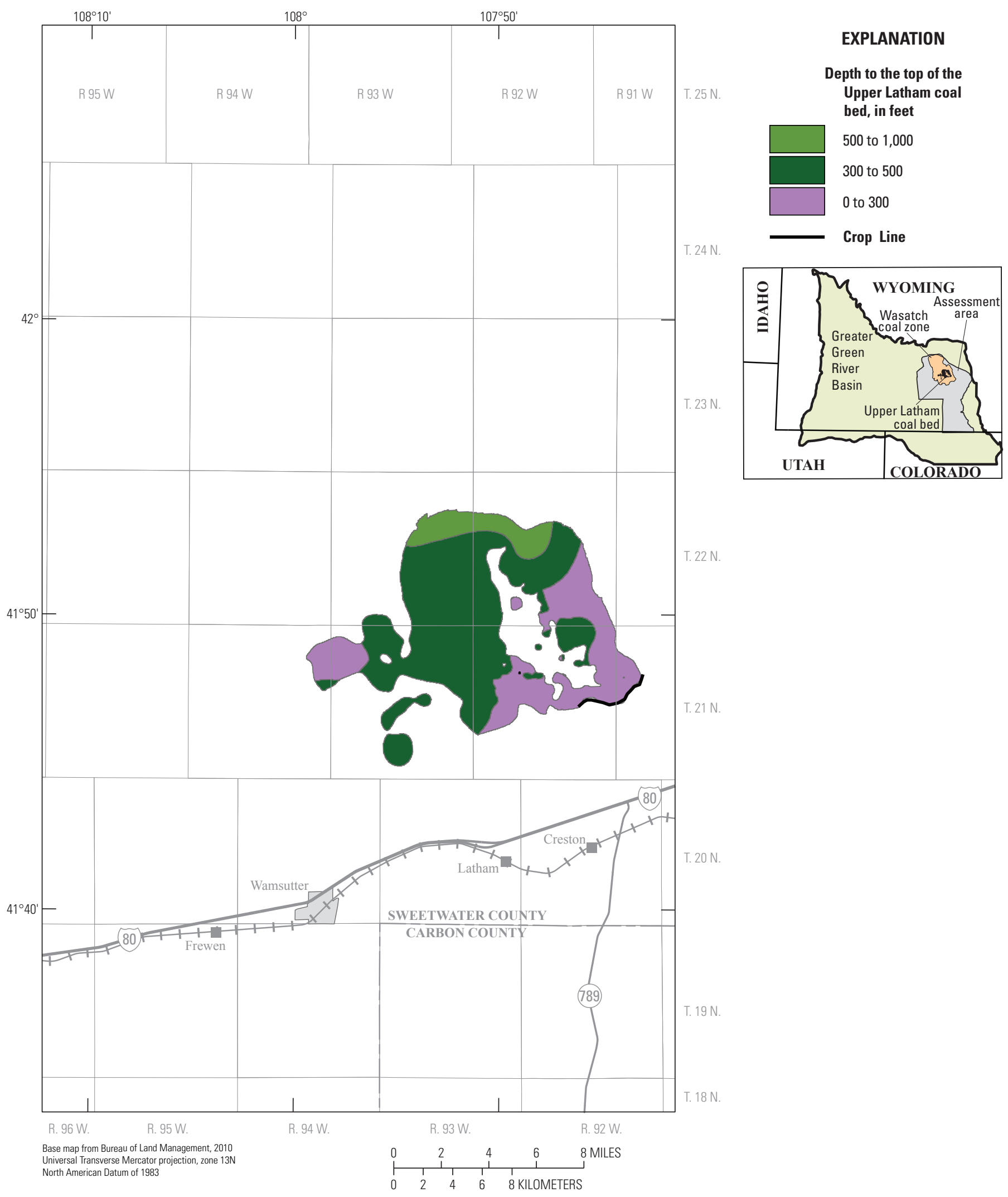

Figure 34. Depth to the top of the upper Latham coal bed within the Little Snake River coal field and Red Desert assessment area, Greater Green River Basin, Wyoming. 


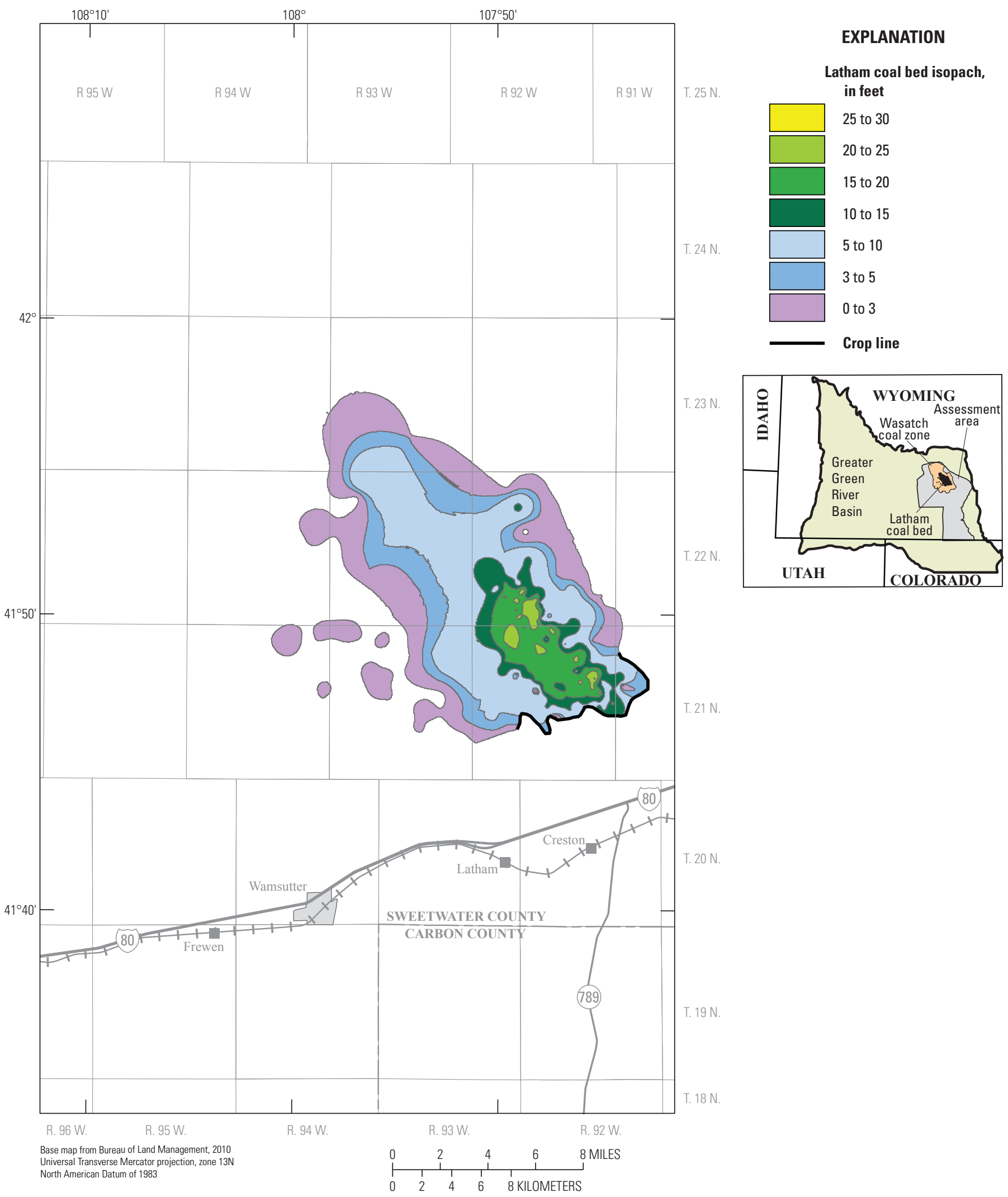

Figure 35. Latham coal bed showing extent of coal within the Little Snake River coal field and Red Desert assessment area, Greater Green River Basin, Wyoming. 


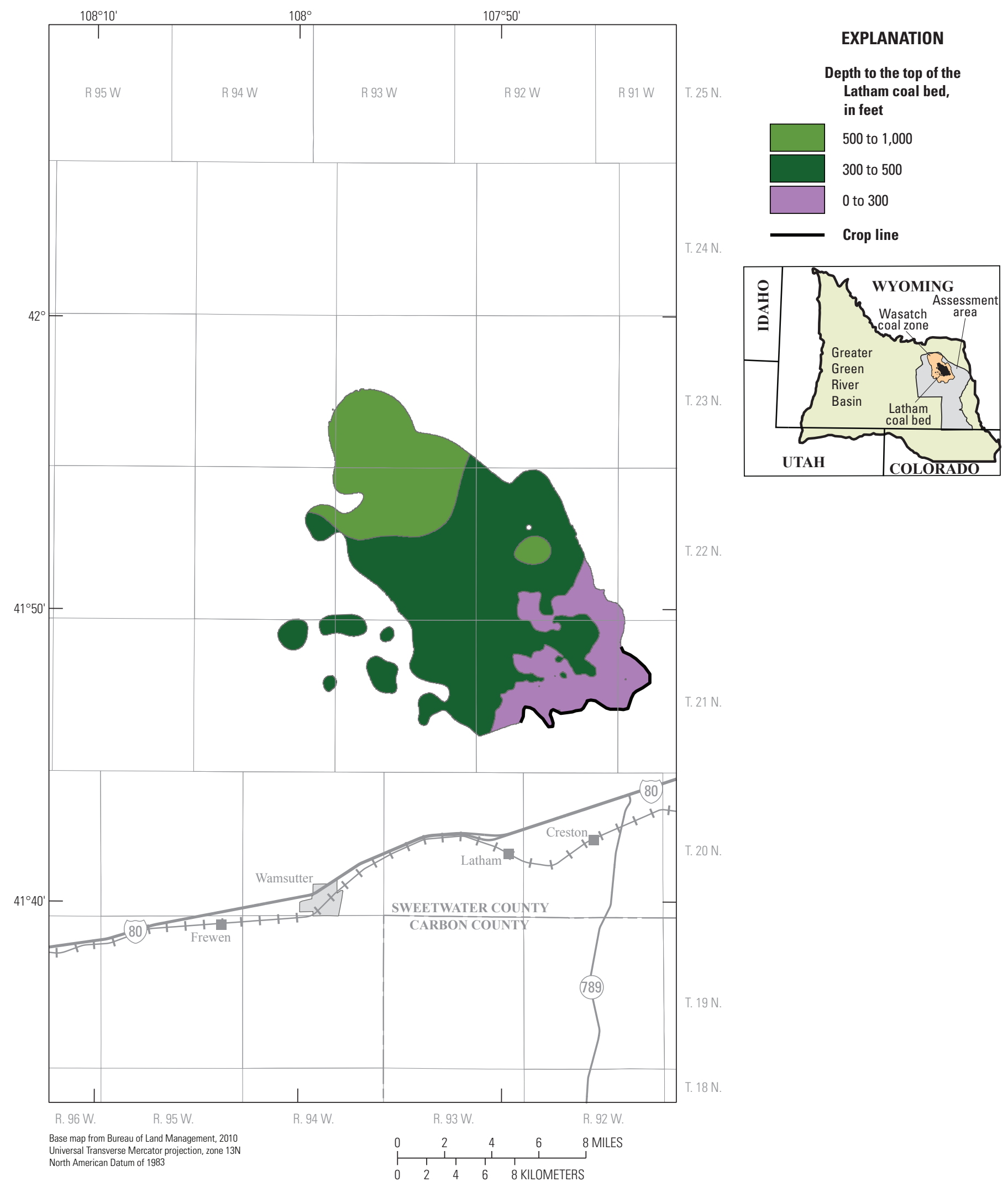

Figure 36. Depth to the top of the Latham coal bed within the Little Snake River coal field and Red Desert assessment area, Greater Green River Basin, Wyoming. 


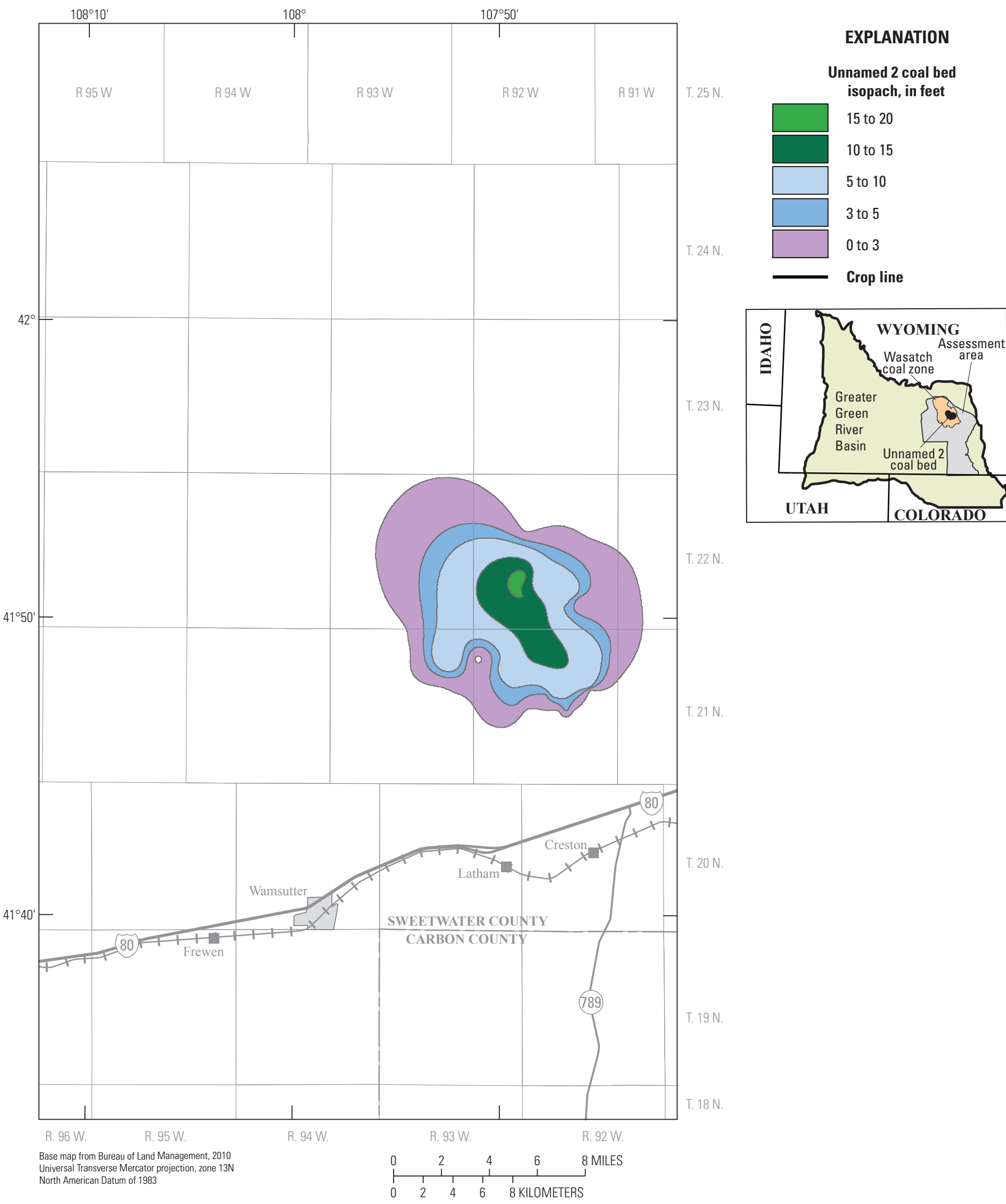

Figure 37. Unnamed 2 coal bed showing extent of coal within the Little Snake River coal field and Red Desert assessment area, Greater Green River Basin, Wyoming. 


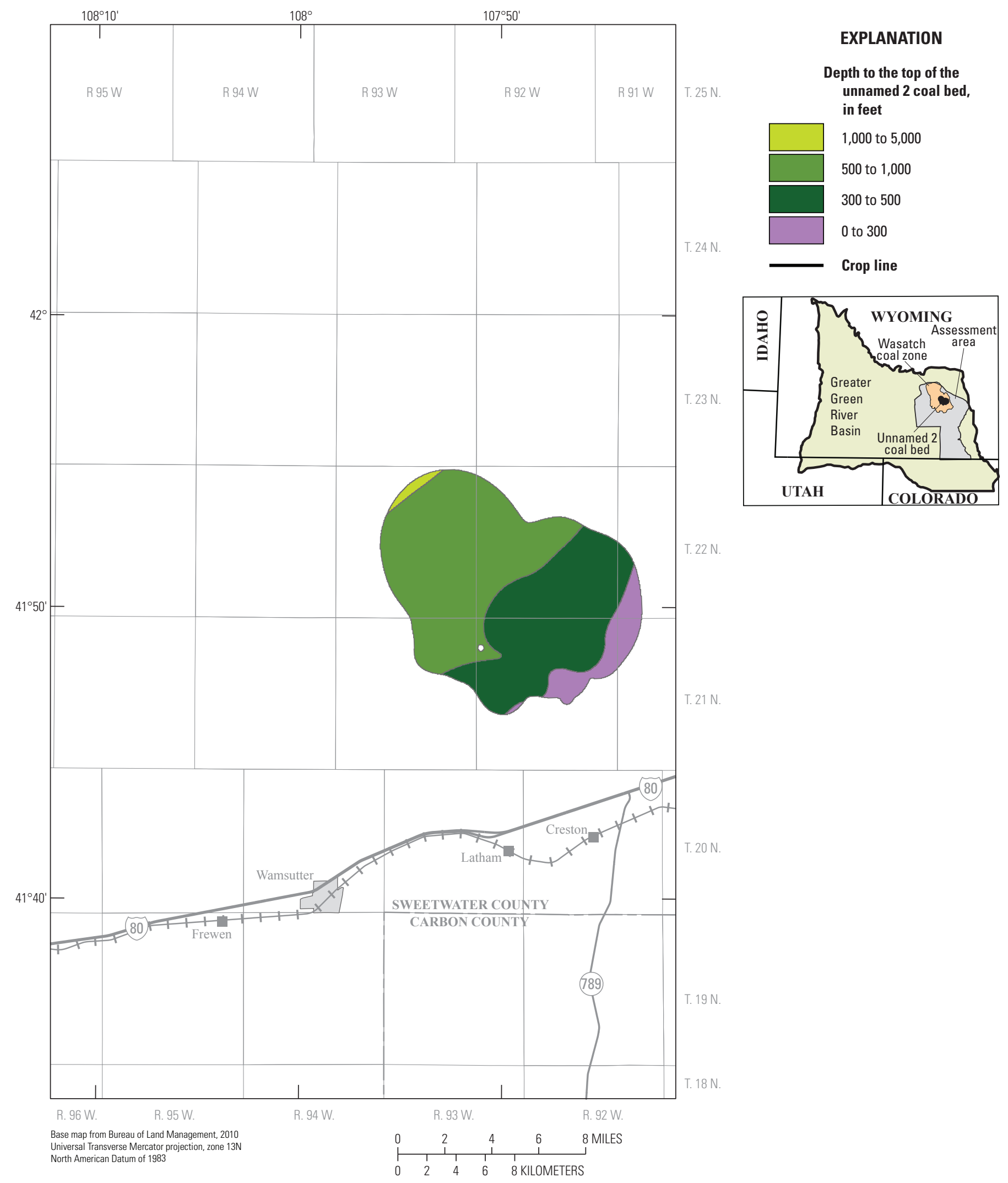

Figure 38. Depth to the top of the unnamed 2 coal bed within the Little Snake River coal field and Red Desert assessment area, Greater Green River Basin, Wyoming. 


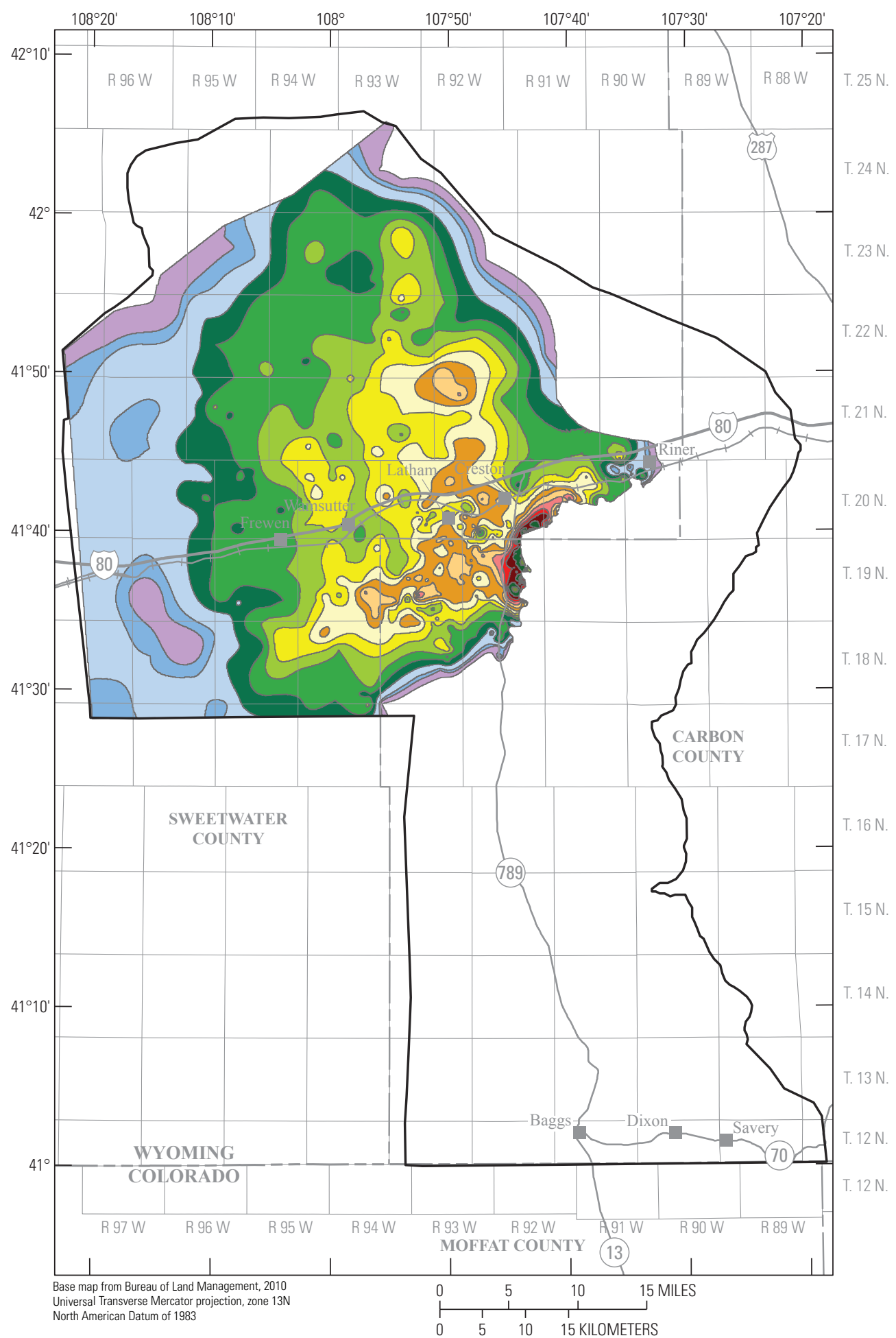

\section{EXPLANATION}

Overland coal zone total coal isopach, in feet

Greater than 80

75 to 80

70 to 75

65 to 70

60 to 65

55 to 60

50 to 55

45 to 50

40 to 45

35 to 40

30 to 35

25 to 30

20 to 25

15 to 20

10 to 15

5 to 10

3 to 5

0 to 3

Little Snake River coal field and Red Desert assessment area boundary

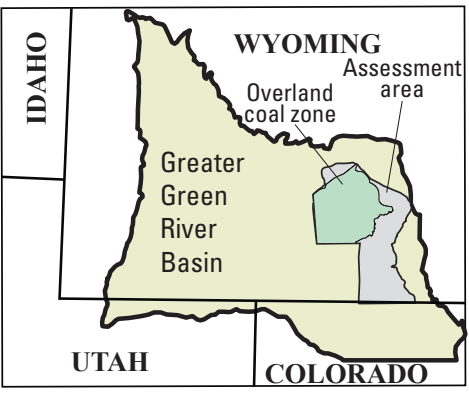

Figure 39. Composite thickness of all coal beds in the Overland coal zone of the Fort Union Formation within the Little Snake River coal field and Red Desert assessment area, Greater Green River Basin, Wyoming. Modified from Hettinger and others (2008). 


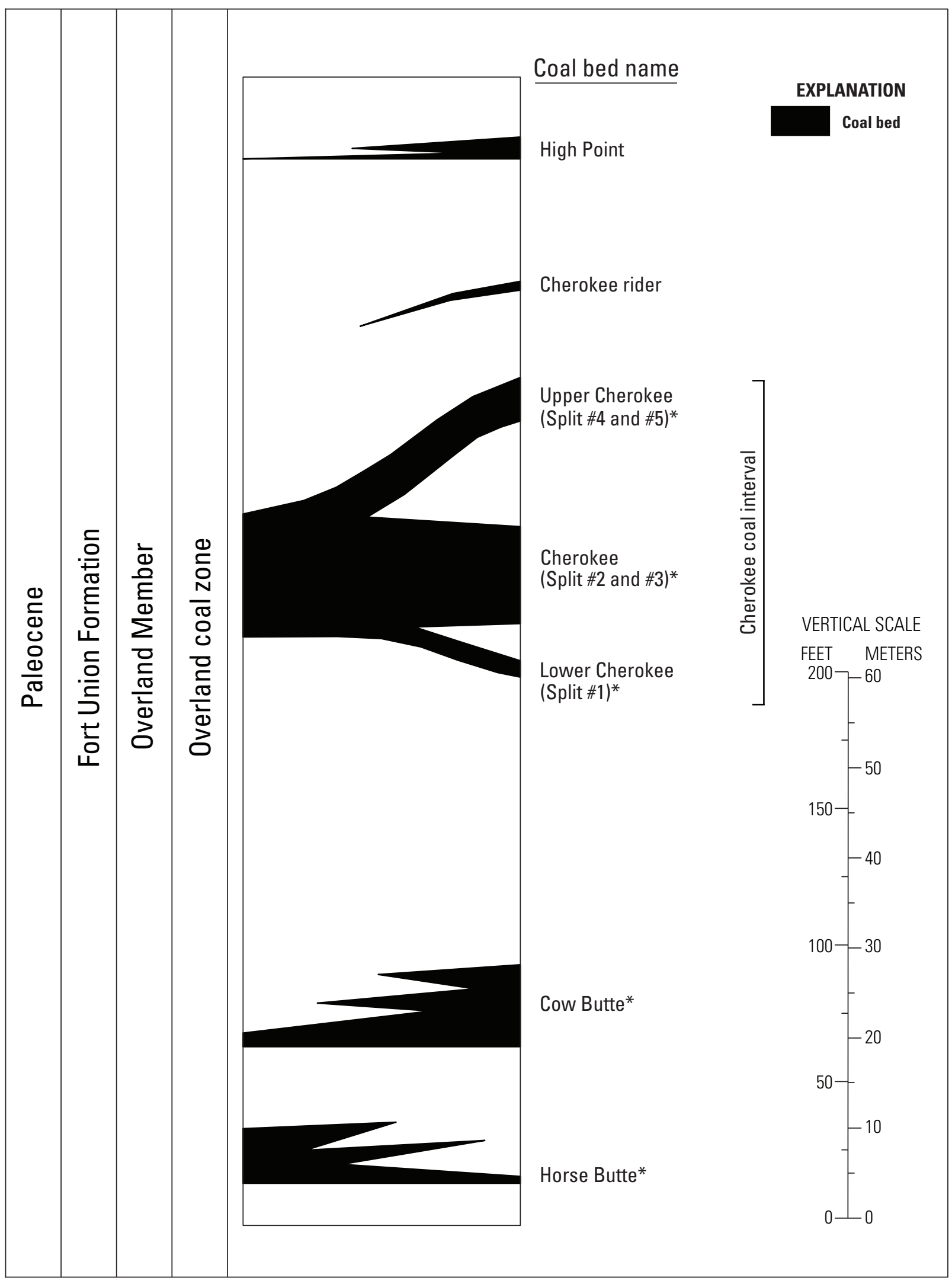

Figure 40. Generalized stratigraphic column showing coal beds in the Overland coal zone of the Fort Union Formation in the Little Snake River coal field and Red Desert assessment area, Greater Green River Basin, Wyoming. Asterisk indicates that resources were calculated for bed. 


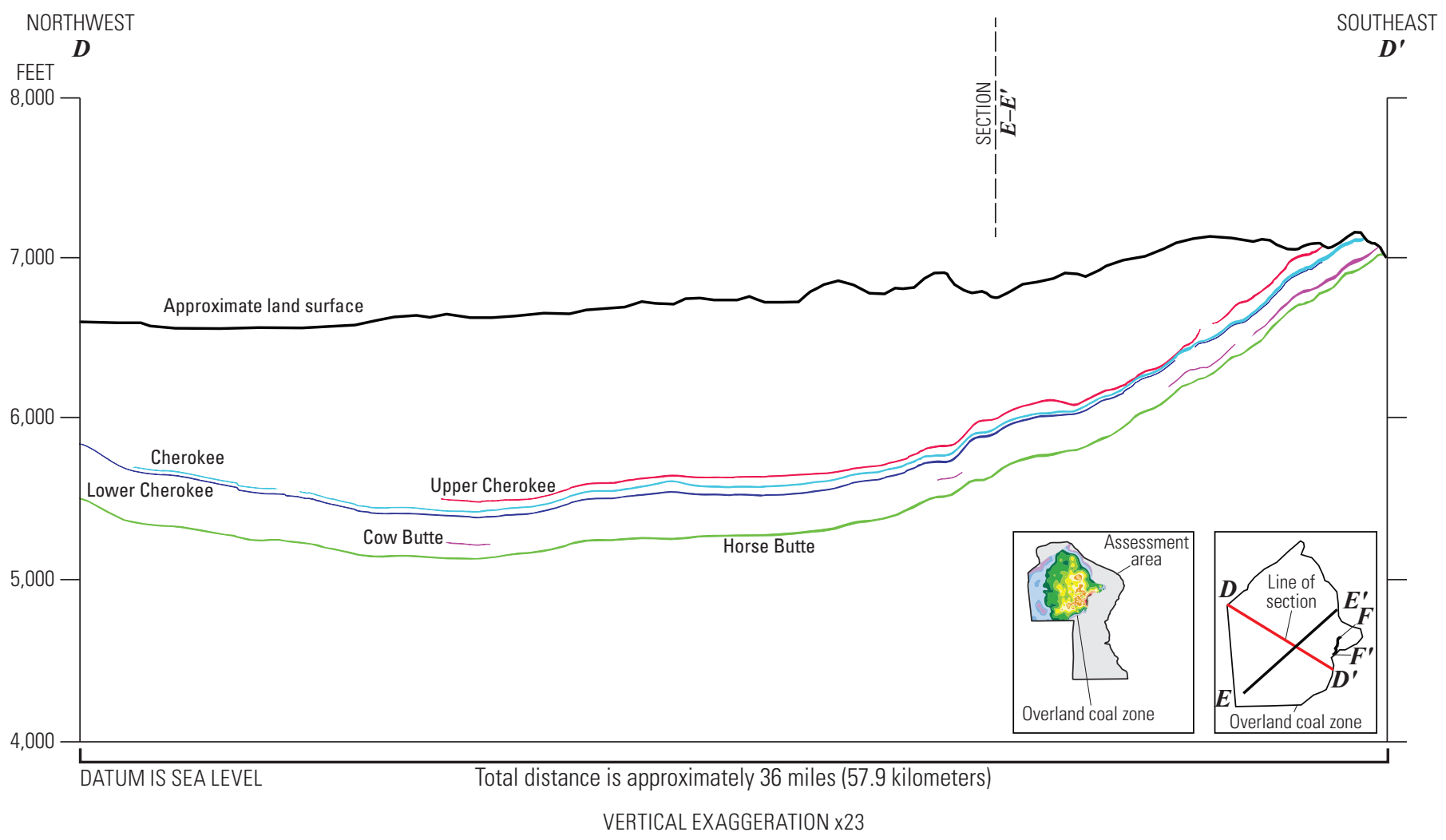

Figure 41. Northwest-southeast cross section $D-D$ 'showing approximate subsurface distribution of coal beds in the Overland coal zone in the Little Snake River coal field and Red Desert assessment area, Greater Green River Basin, Wyoming. Modified from Hettinger and others (2008). 


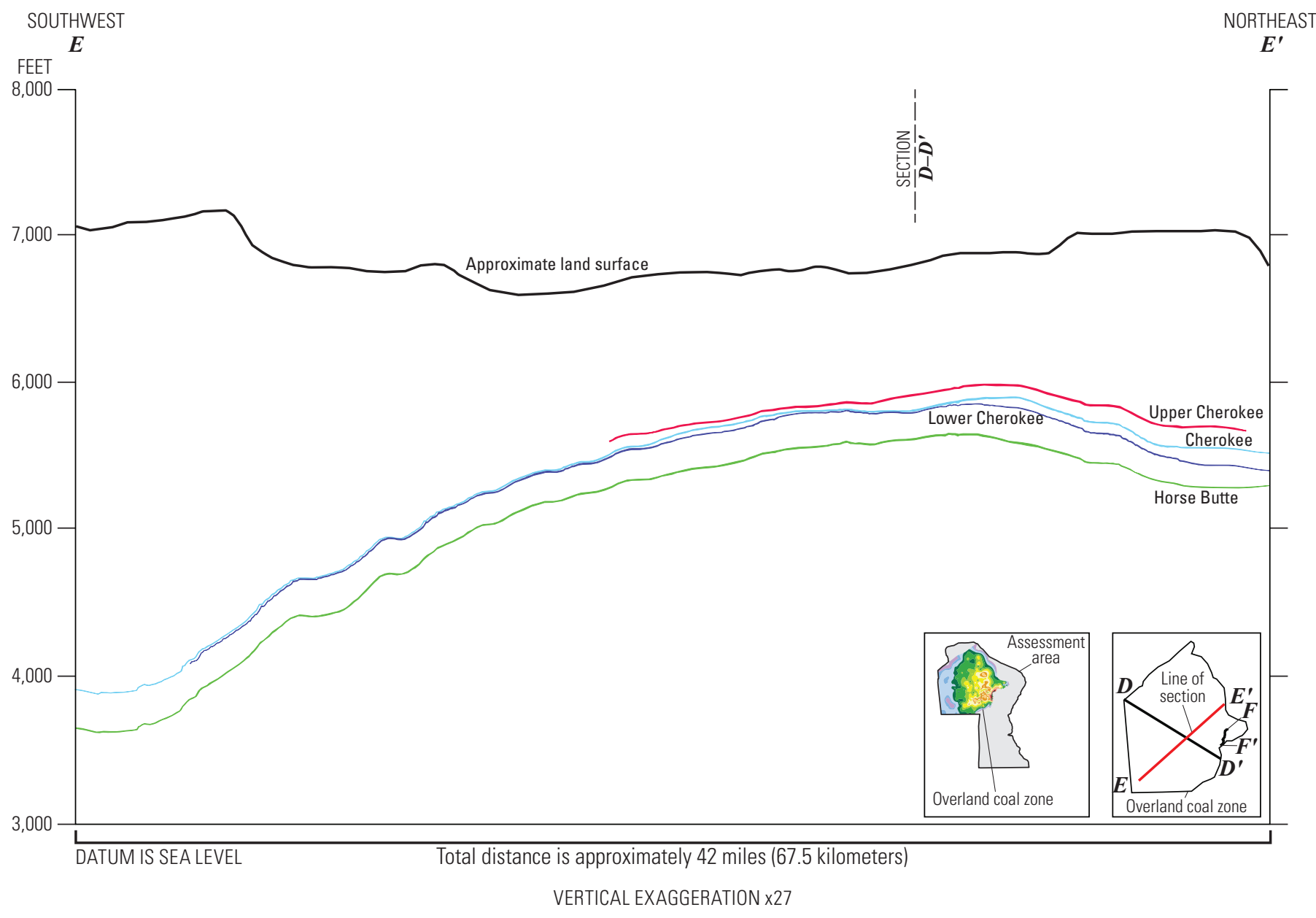

Figure 42. Southwest-northeast cross section $E-E^{\prime}$ showing approximate subsurface distribution of coal beds in the Overland coal zone in the Little Snake River coal field and Red Desert assessment area, Greater Green River Basin, Wyoming. 


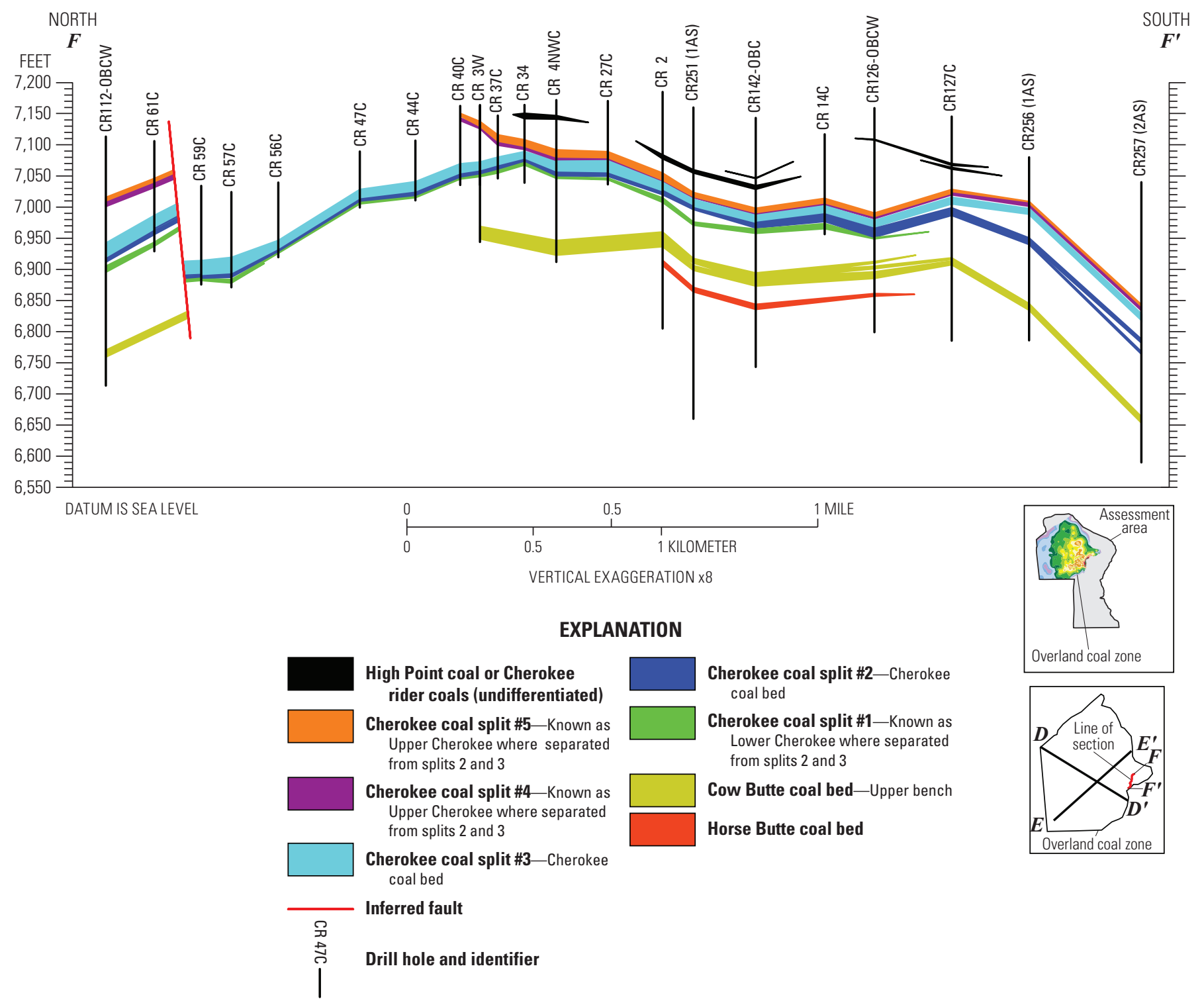

Figure 43. Cross section $F-F^{\prime}$ showing splitting of the Cherokee bed in the Overland coal zone in the Little Snake River coal field and Red Desert assessment area, Greater Green River Basin, Wyoming. Emphasis is given to the splitting of the Cherokee coal bed. All drill hole data are from Anadarko Land Corporation (Donald Ballard, Anadarko Land Corporation, oral commun., 2013). 


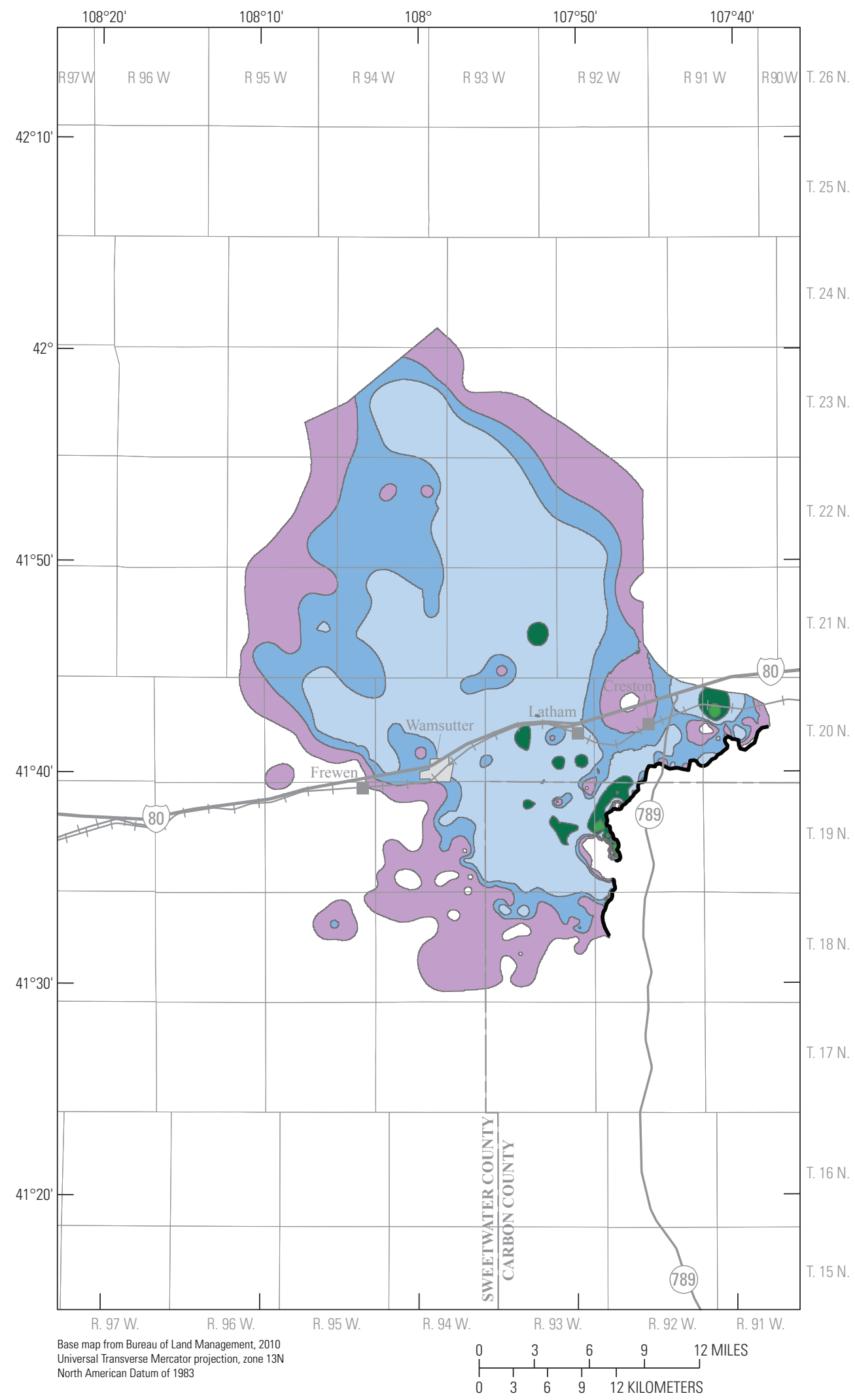

EXPLANATION

Upper Cherokee coal bed isopach, in feet

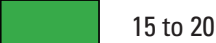

10 to 15

5 to 10

3 to 5

0 to 3

$\longrightarrow$ Crop line

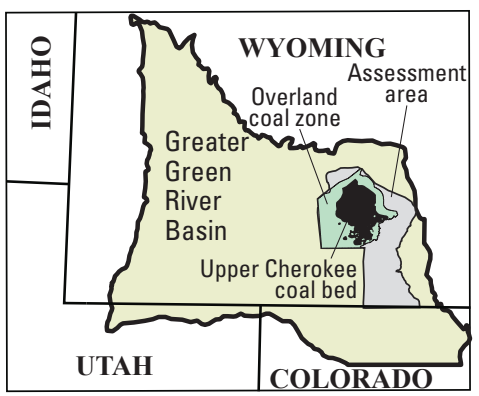

Figure 44. Upper Cherokee coal bed showing extent of coal within the Little Snake River coal field and Red Desert assessment area, Greater Green River Basin, Wyoming. 


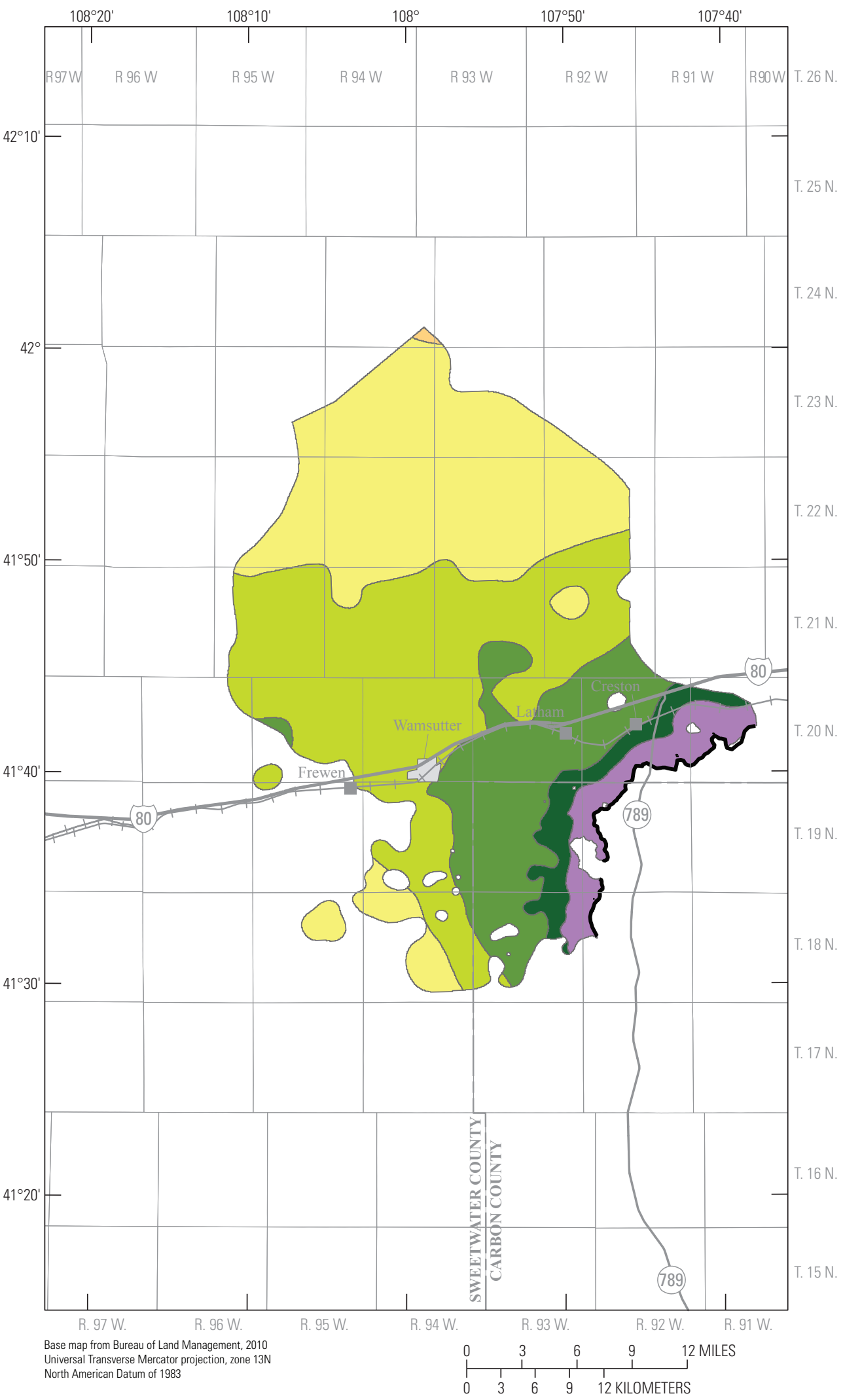

EXPLANATION

Depth to the top of the upper Cherokee coal bed in feet

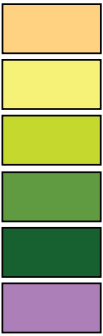

Greater than 3,000

1,500 to 3,000

1,000 to 1,500

500 to 1,000

300 to 500

0 to 300
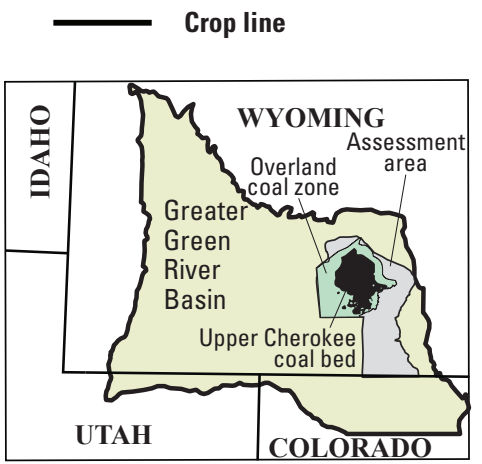

Figure 45. Depth to the top of the Upper Cherokee coal bed within the Little Snake River coal field and Red Desert assessment area, Greater Green River Basin, Wyoming. 


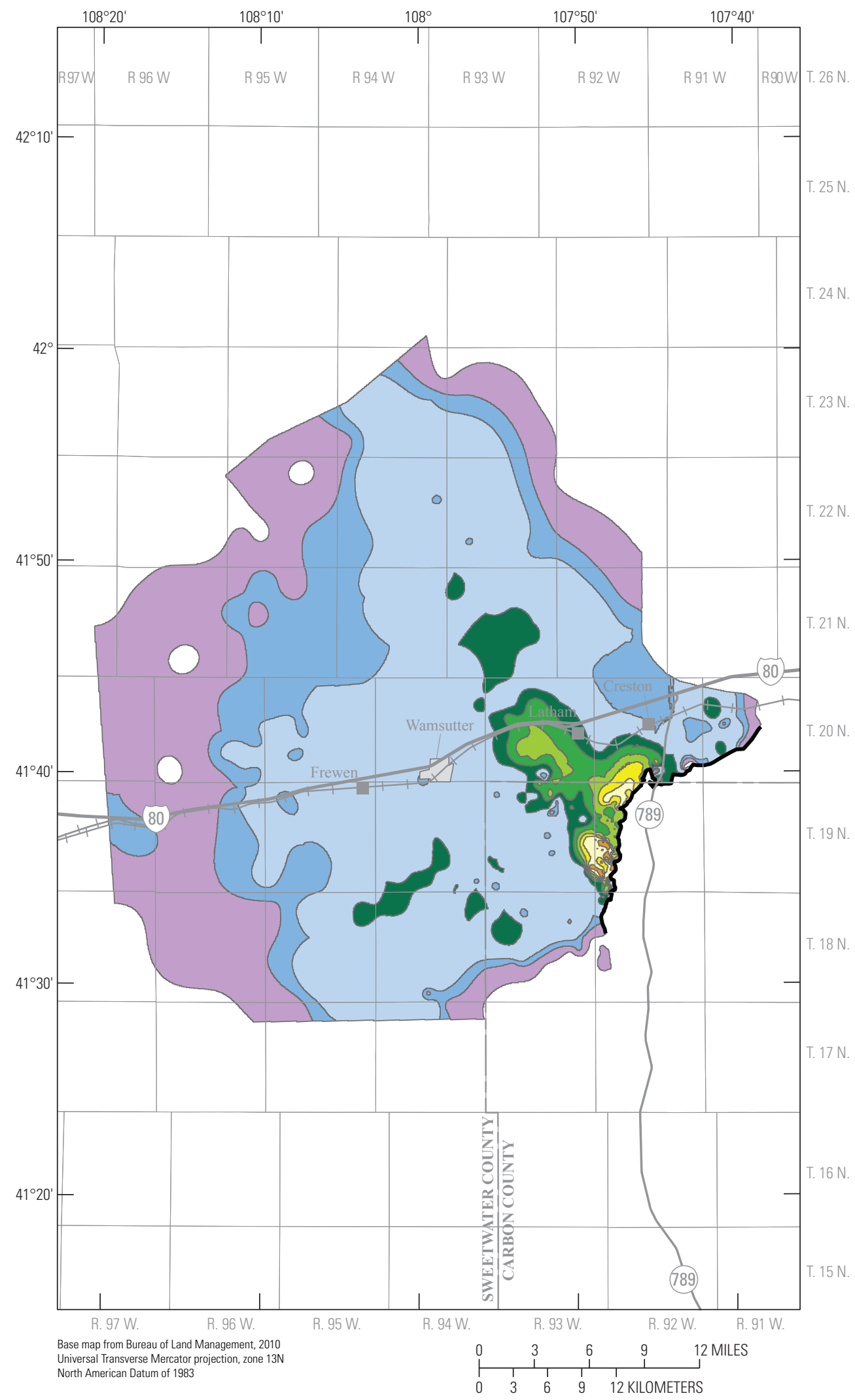

EXPLANATION
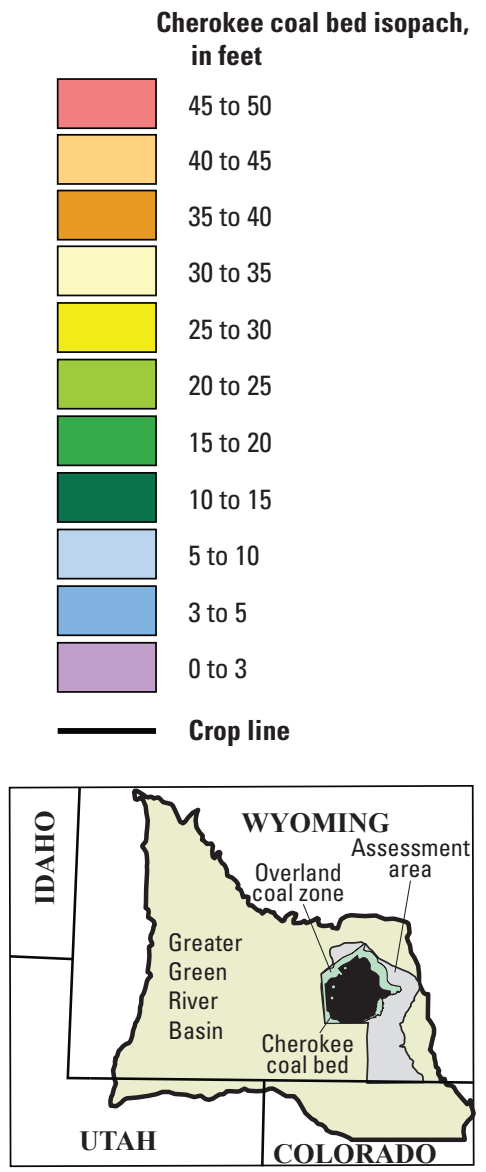

Figure 46. Cherokee coal bed showing extent of coal within the Little Snake River coal field and Red Desert assessment area, Greater Green River Basin, Wyoming. 


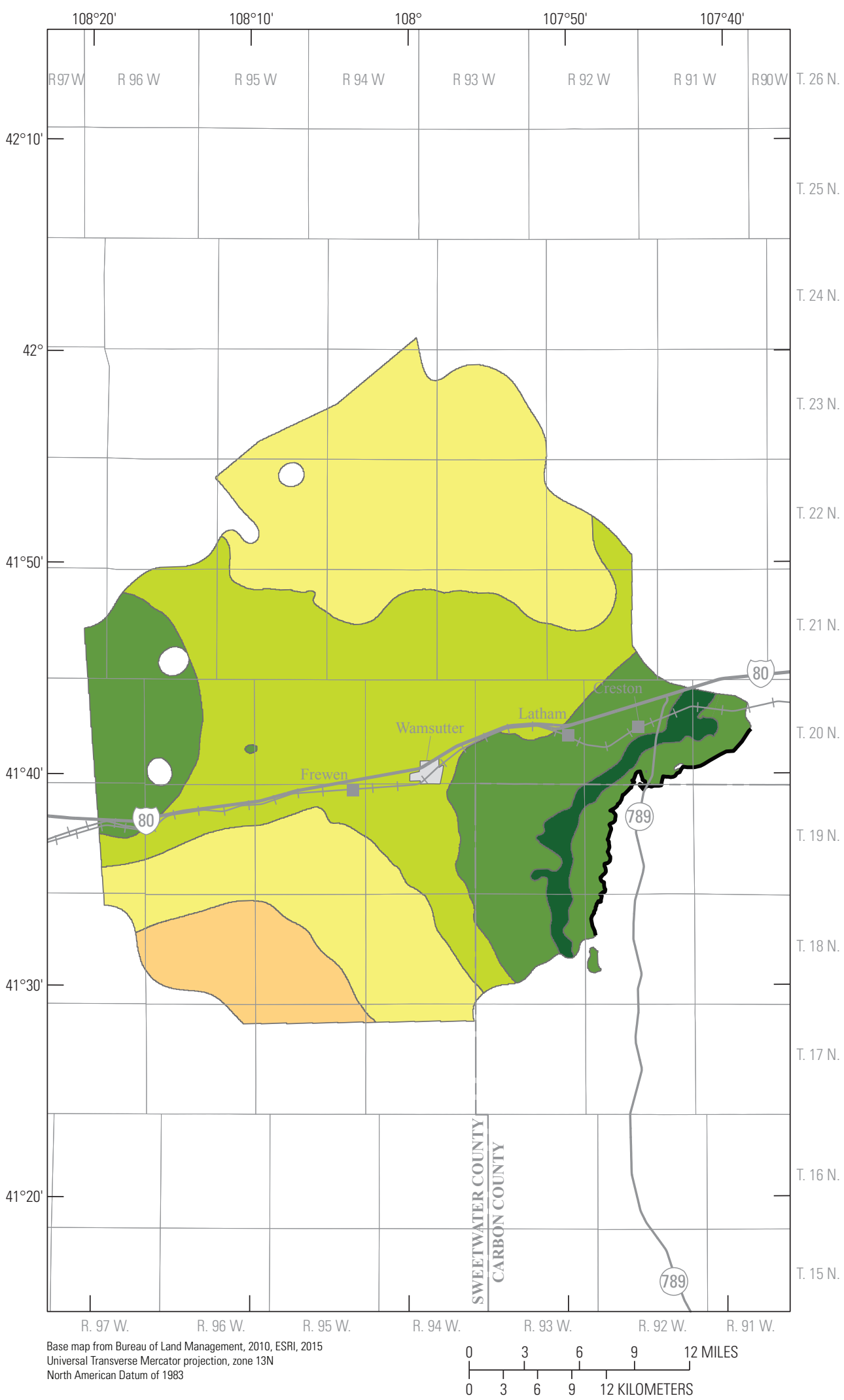

EXPLANATION

Depth to the top of the Cherokee coal bed, in feet

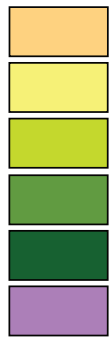

Greater than 3,000

1,500 to 3,000

1,000 to 1,500

500 to 1,000

300 to 500

0 to 300
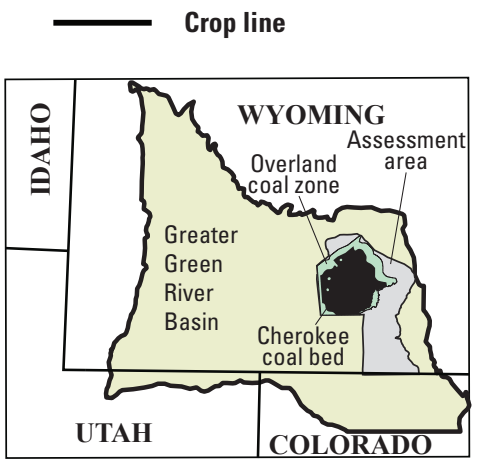

Figure 47. Depth to the top of the Cherokee coal bed within the Little Snake River coal field and Red Desert assessment area, Greater Green River Basin, Wyoming. 


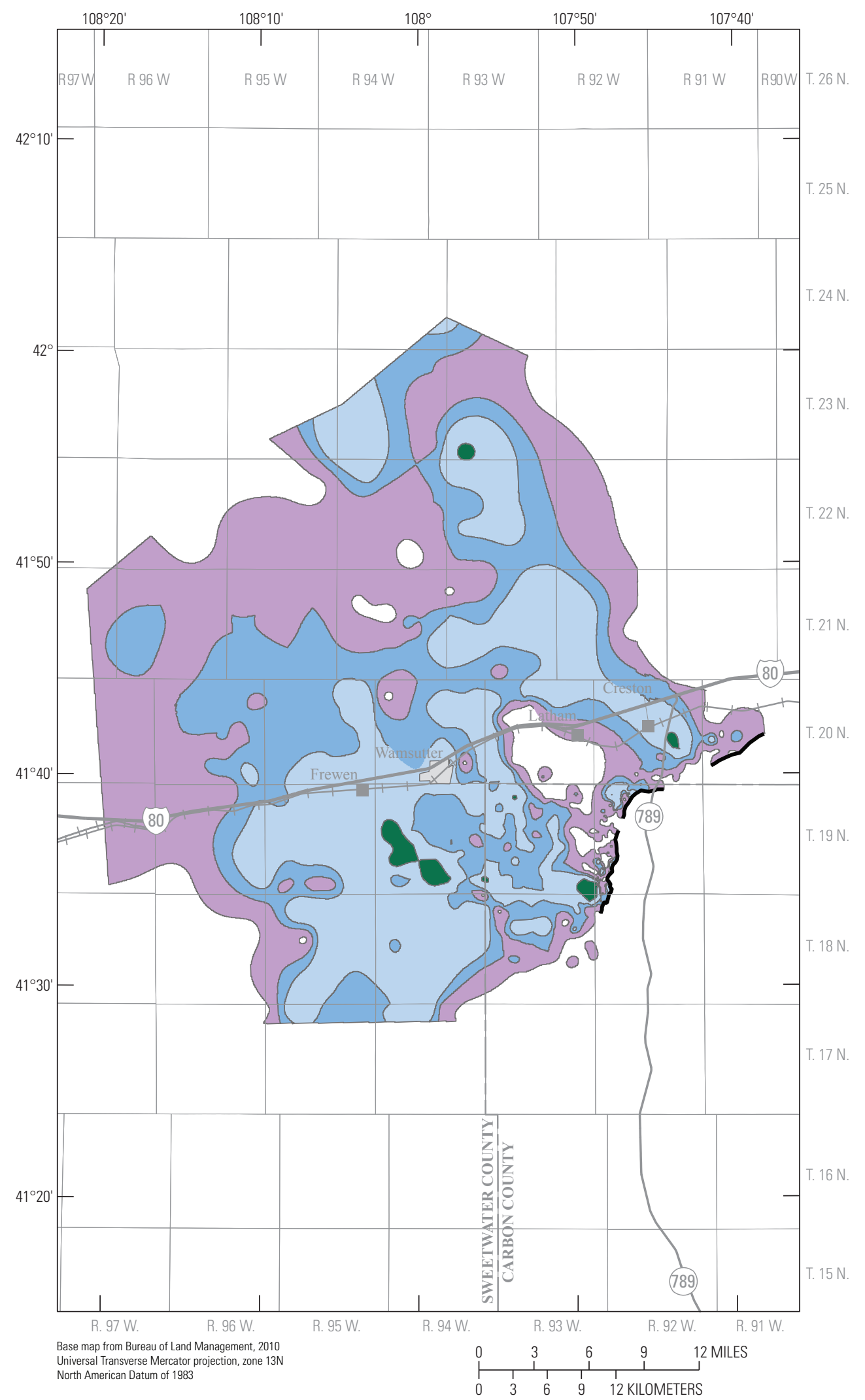

\section{EXPLANATION}

Lower Cherokee coal bed isopach, in feet

15 to 20

10 to 15

5 to 10

3 to 5

0 to 3

Crop line

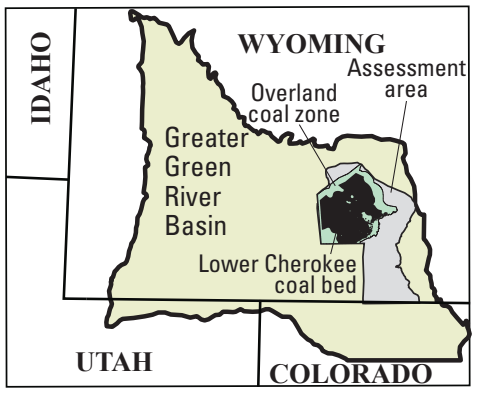

Figure 48. Lower Cherokee coal bed showing extent of coal within the Little Snake River coal field and Red Desert assessment area, Greater Green River Basin, Wyoming. 


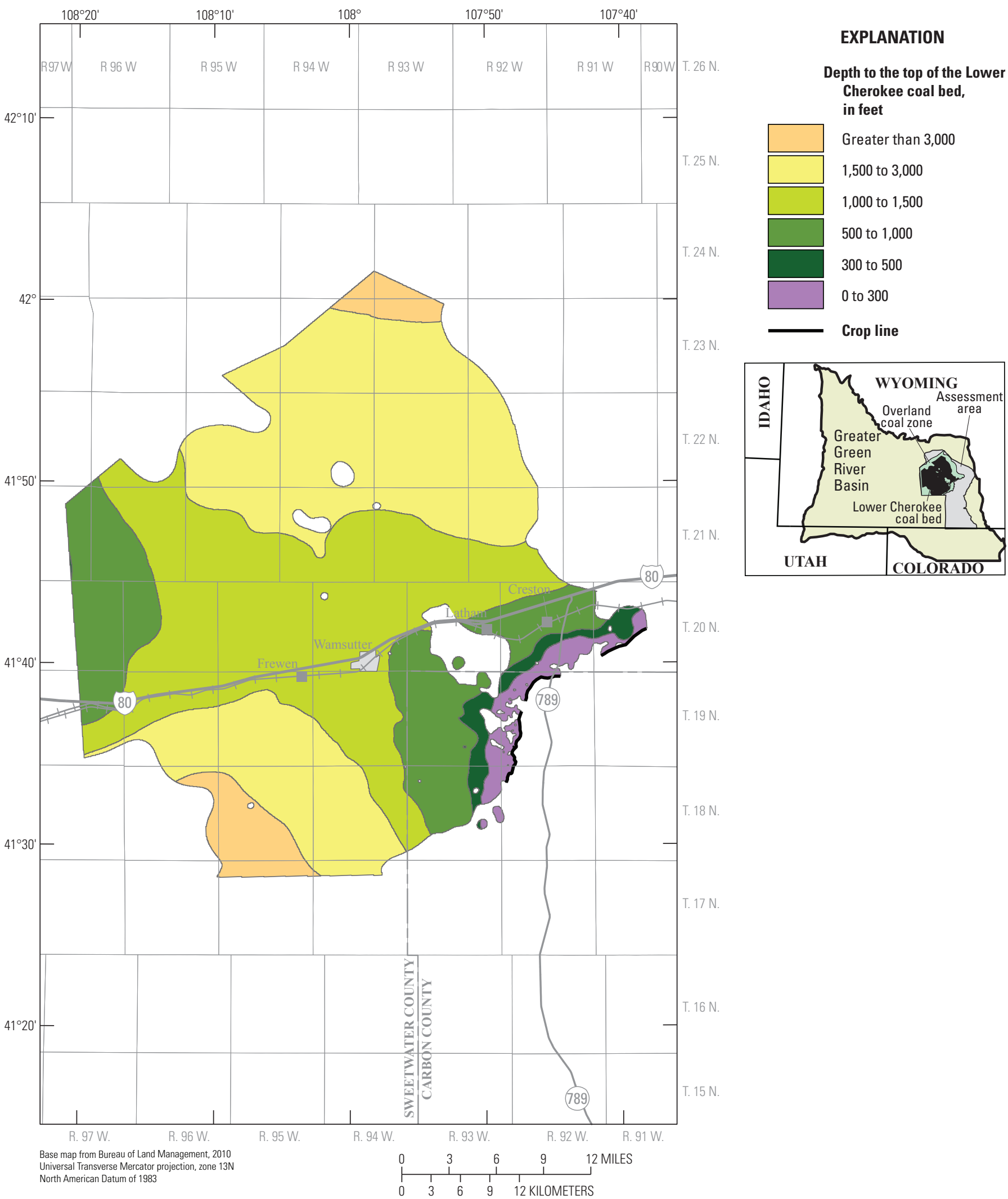

Figure 49. Depth to the top of the Lower Cherokee coal bed within the Little Snake River coal field and Red Desert assessment area, Greater Green River Basin, Wyoming. 


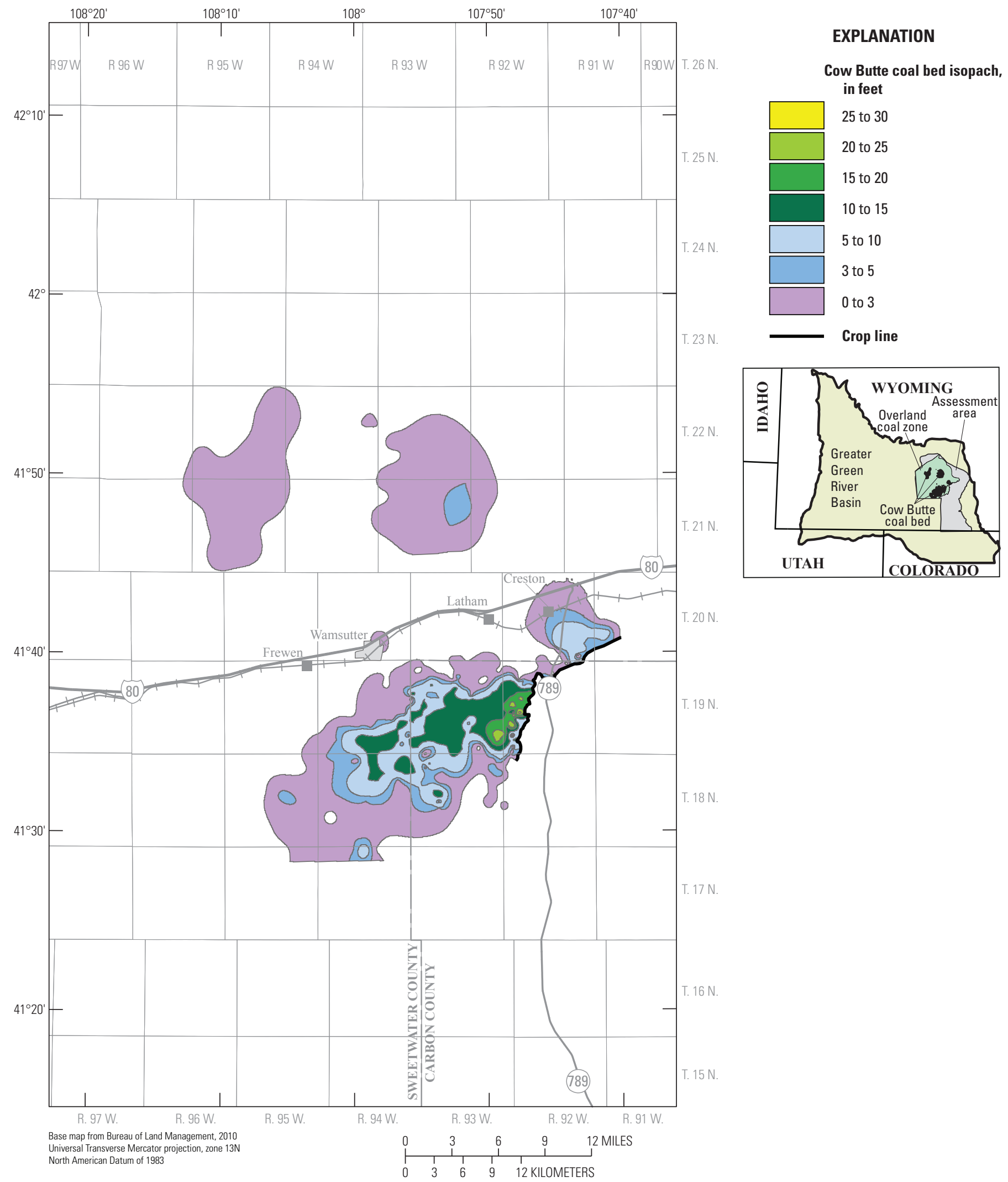

Figure 50. Cow Butte coal bed showing extent of coal within the Little Snake River coal field and Red Desert assessment area, Greater Green River Basin, Wyoming. 


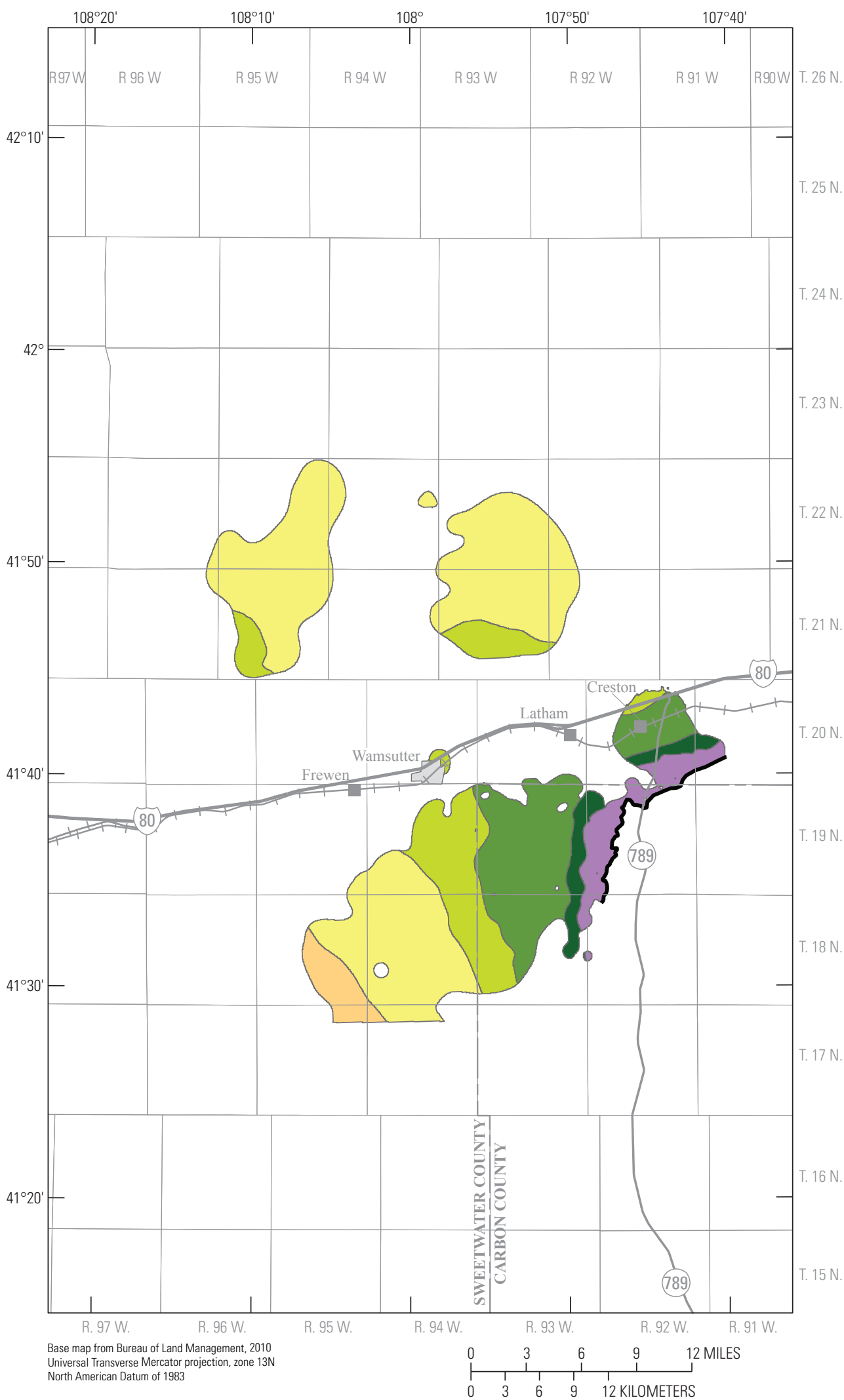

EXPLANATION

Depth to the top of the Cow Butte coal bed, in feet

Greater than 3,000

1,500 to 3,000

1,000 to 1,500

500 to 1,000

300 to 500

0 to 300

Crop line

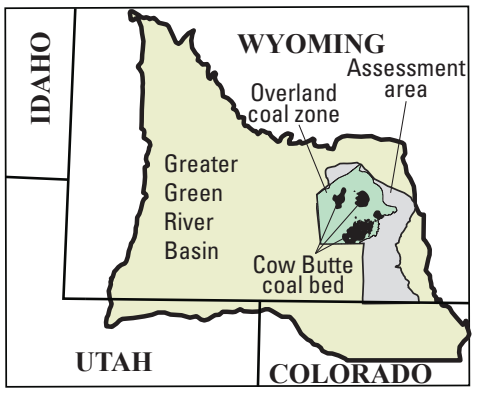

Figure 51. Depth to the top of the Cow Butte coal bed within the Little Snake River coal field and Red Desert assessment area, Greater Green River Basin, Wyoming. 


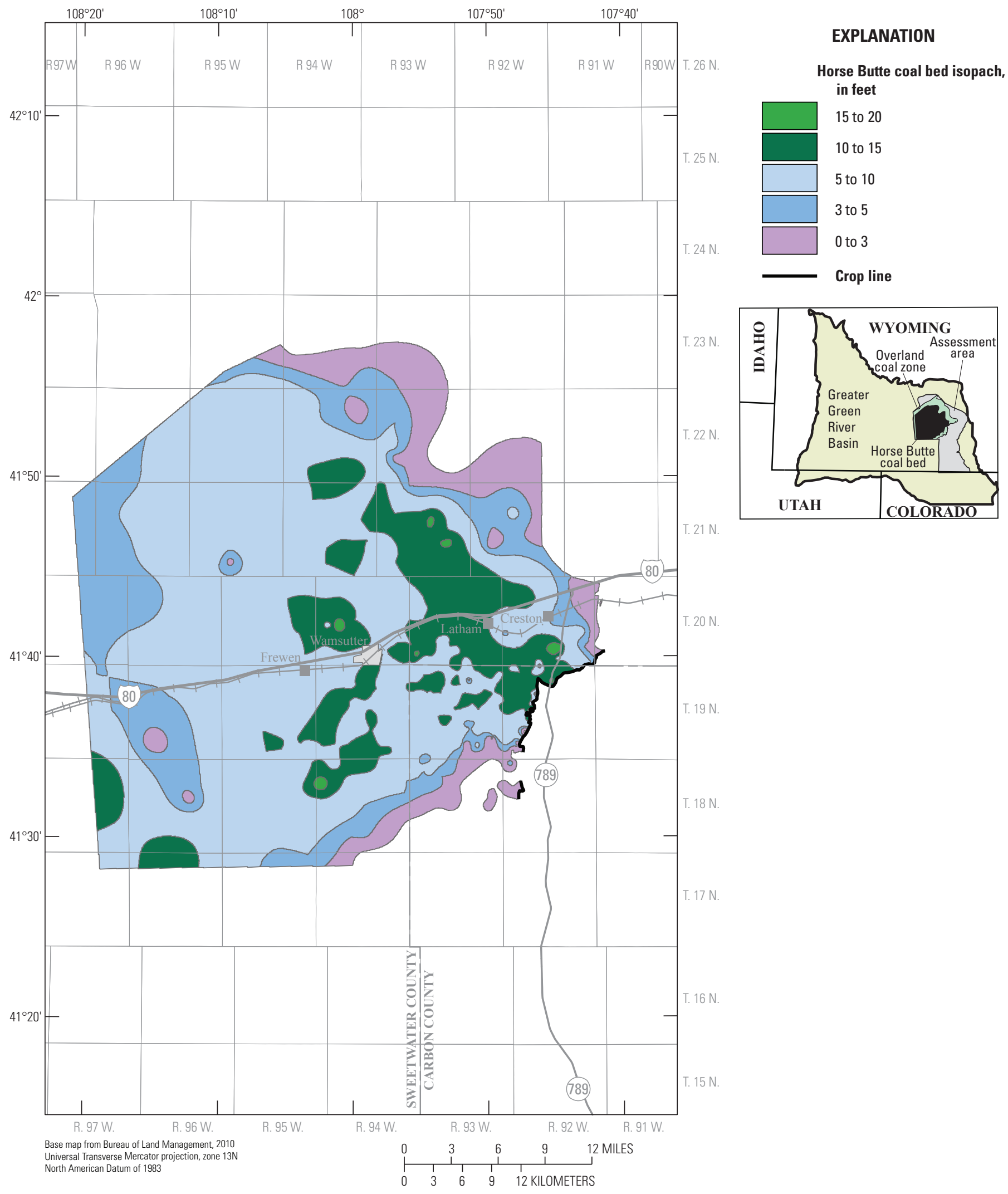

Figure 52. Horse Butte coal bed showing extent of coal within the Little Snake River coal field and Red Desert assessment area, Greater Green River Basin, Wyoming. 


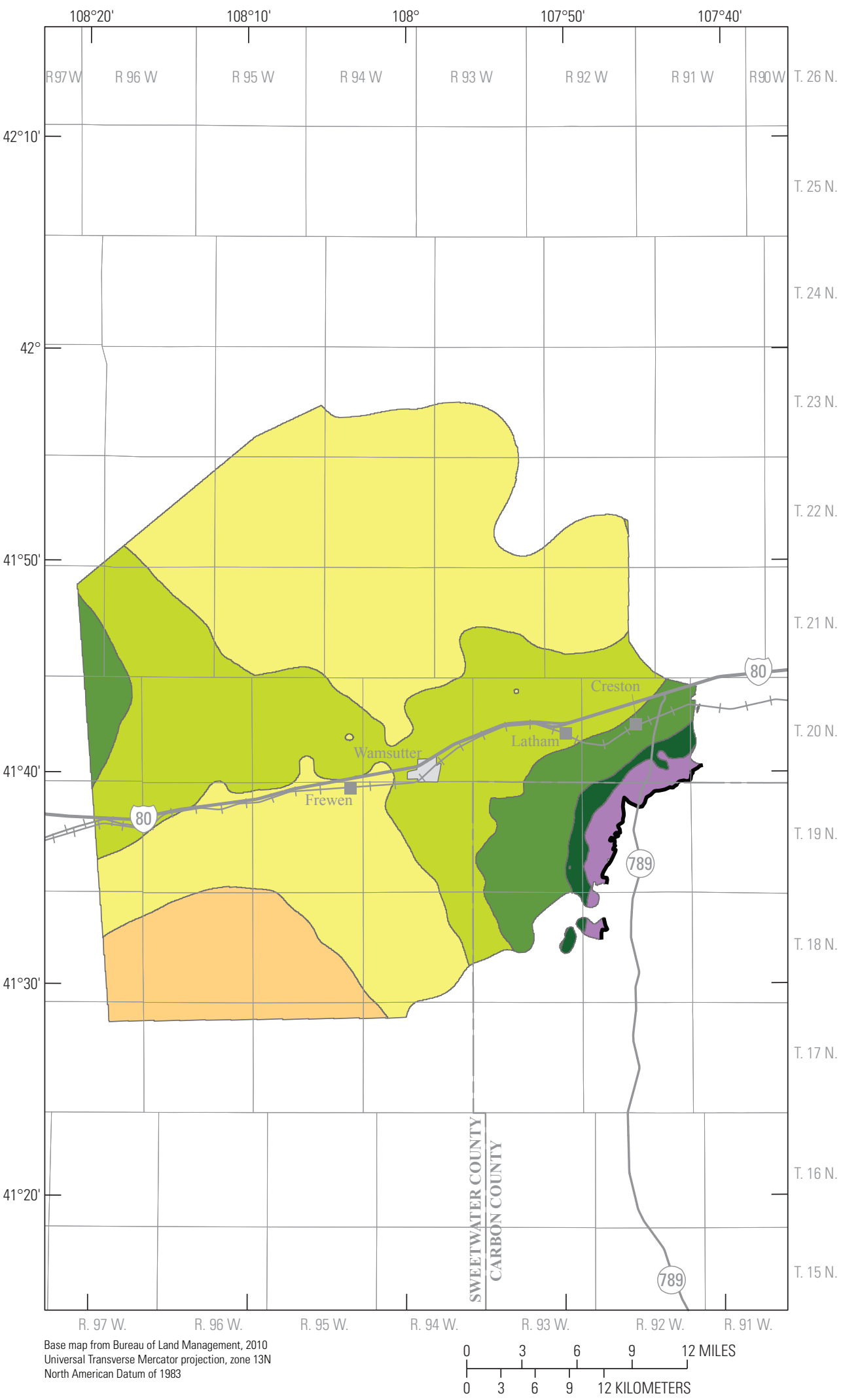

EXPLANATION

Depth to the top of the Horse Butte coal bed, in feet

$\square$ Greater than 3,000

1,500 to 3,000

1,000 to 1,500

500 to 1,000

300 to 500

0 to 300

Crop Line

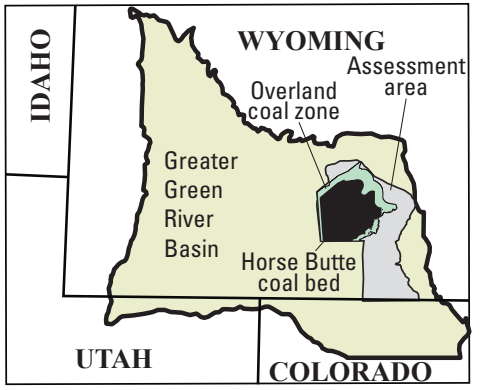

Figure 53. Depth to the top of the Horse Butte coal bed within the Little Snake River coal field and Red Desert assessment area, Greater Green River Basin, Wyoming. 


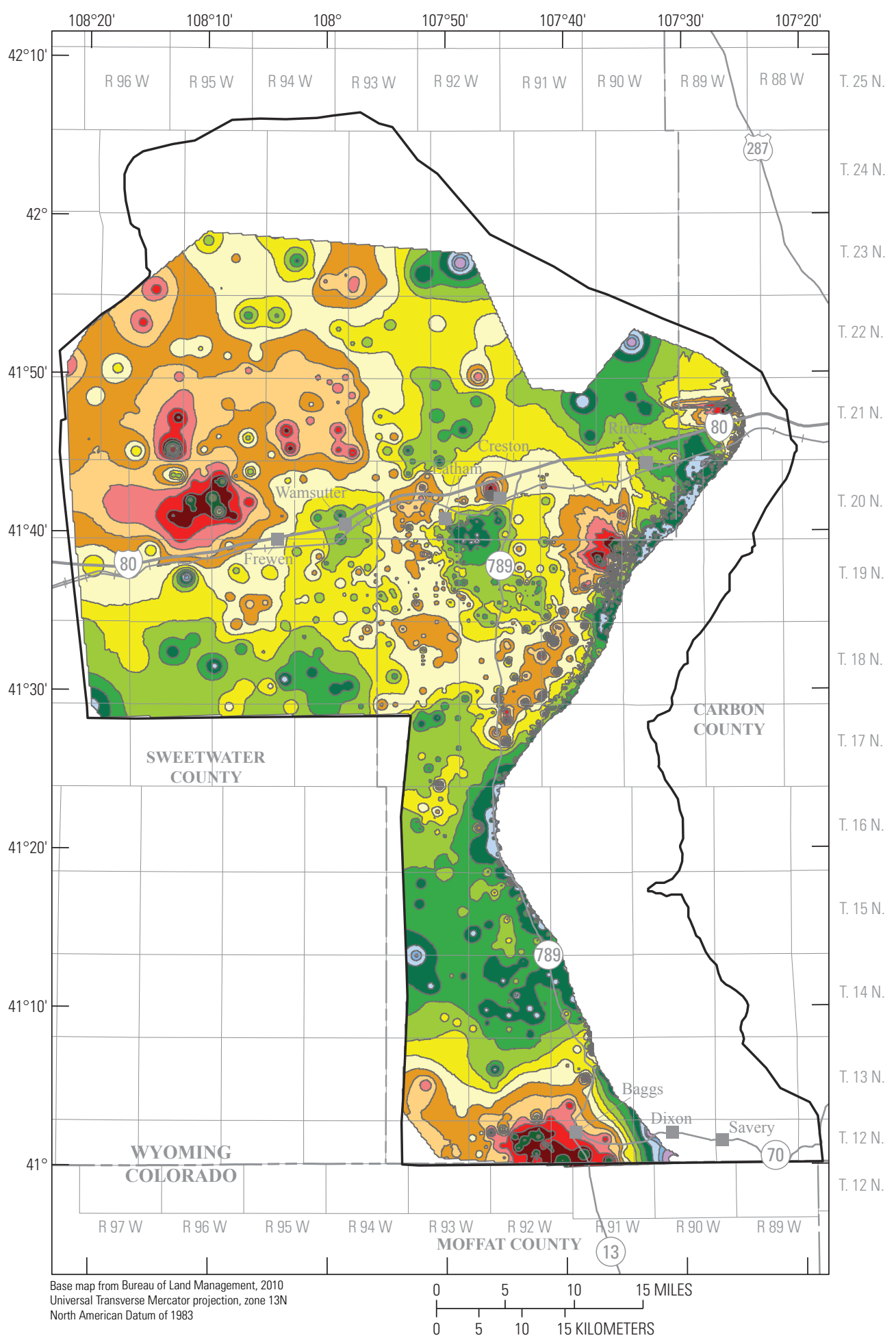

\section{EXPLANATION}

China Butte coal zone total coal isopach, in feet Greater than 80

75 to 80

70 to 75

65 to 70

60 to 65

55 to 60

50 to 55

45 to 50

40 to 45

35 to 40

30 to 35

25 to 30

20 to 25

15 to 20

10 to 15

5 to 10

3 to 5

0 to 3

Little Snake River coal field and Red Desert assessment area boundary

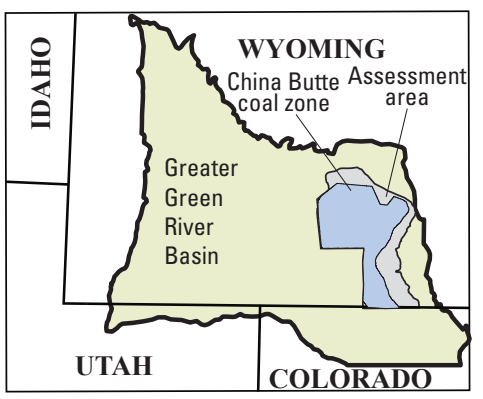

Figure 54. Composite thickness of all coal beds in the China Butte coal zone within the Little Snake River coal field and Red Desert assessment area, Greater Green River Basin, Wyoming. 


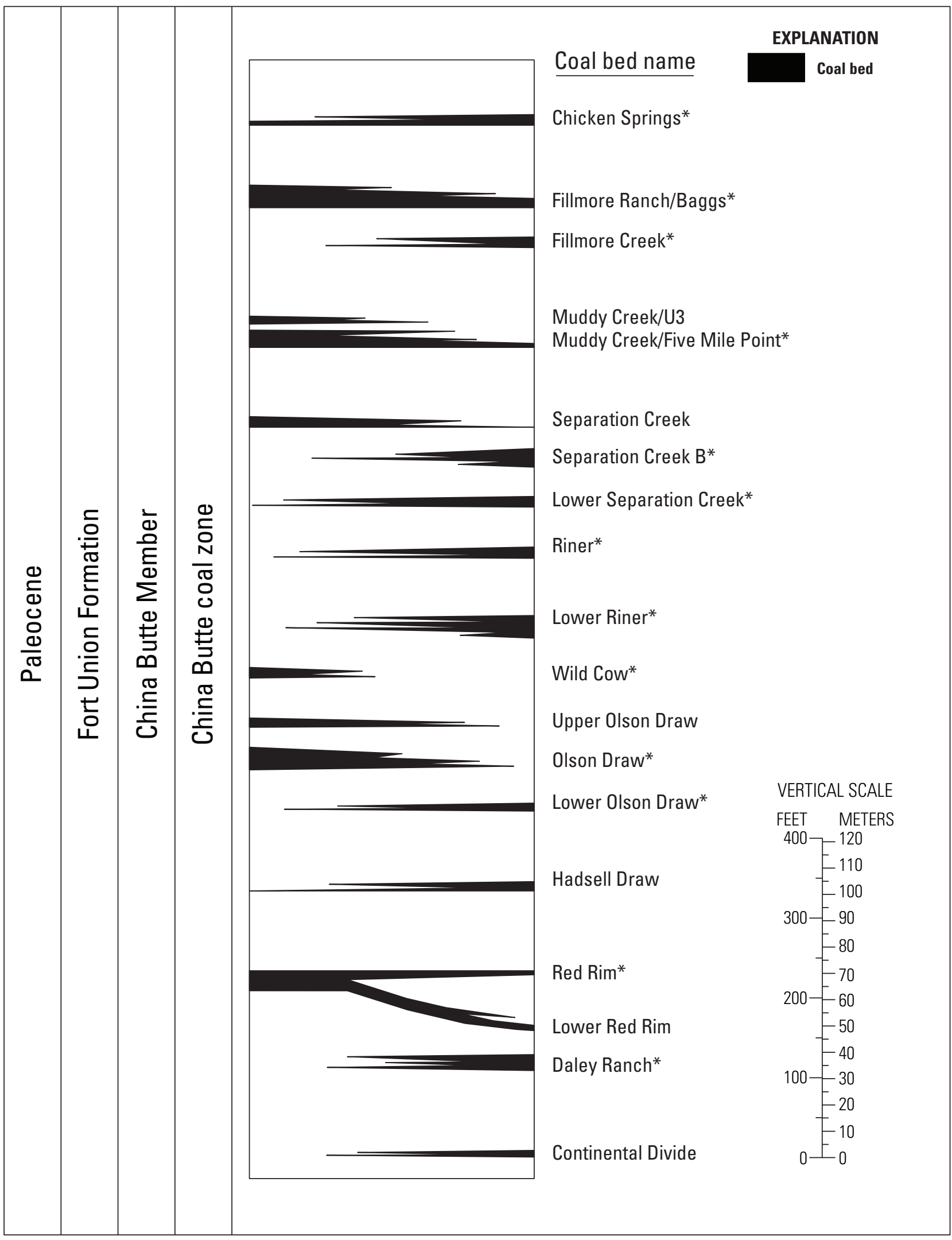

Figure 55. Generalized stratigraphic column showing coal beds in the China Butte coal zone in the Little Snake River coal field and Red Desert assessment area, Greater Green River Basin, Wyoming. Modified from Hettinger and others (2008). Asterisk indicates that resources were calculated for bed. 


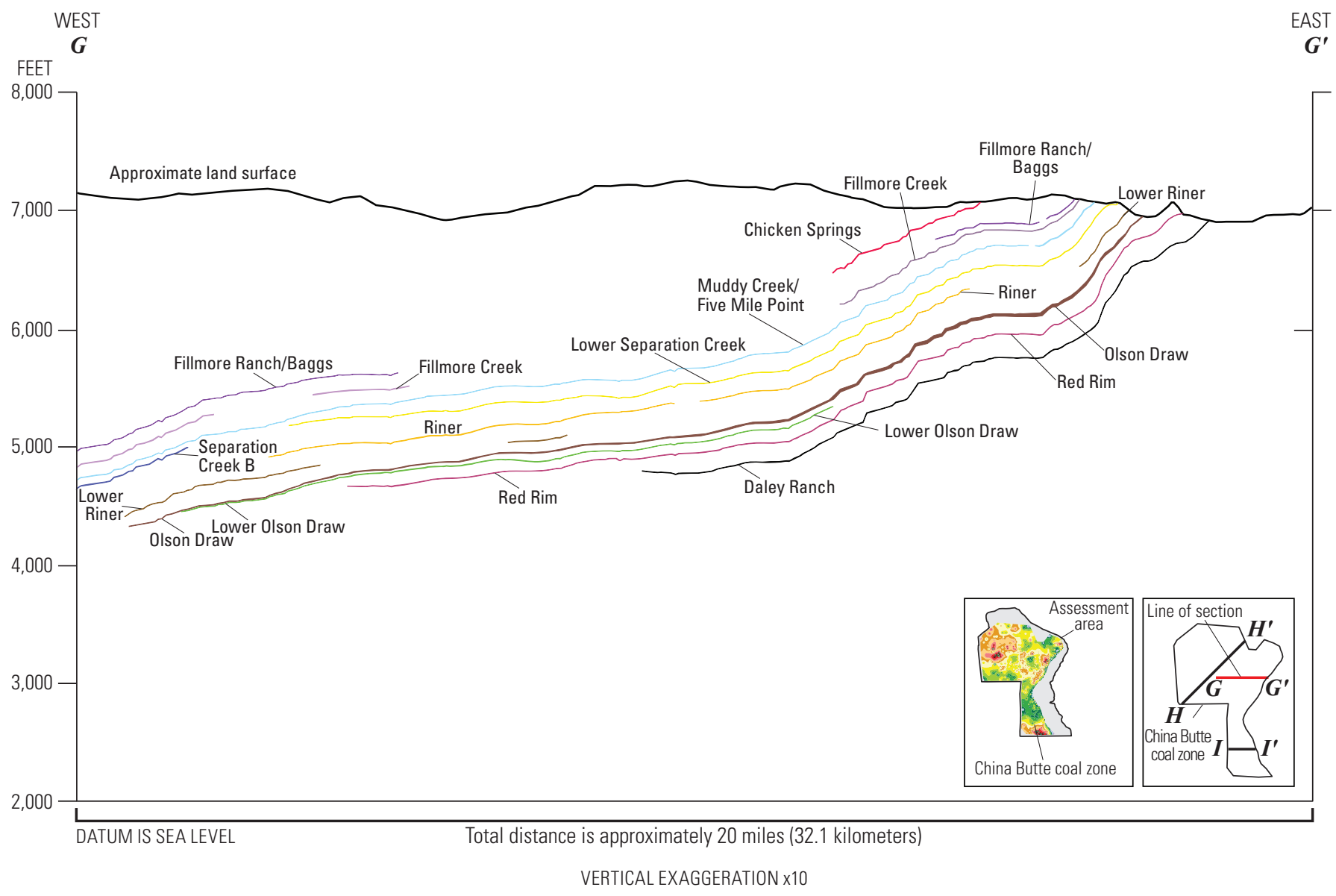

Figure 56. West-east cross section $G-G$ 'showing approximate subsurface distribution of coal beds in the China Butte coal zone in the Little Snake River coal field and Red Desert assessment area, Greater Green River Basin, Wyoming. 


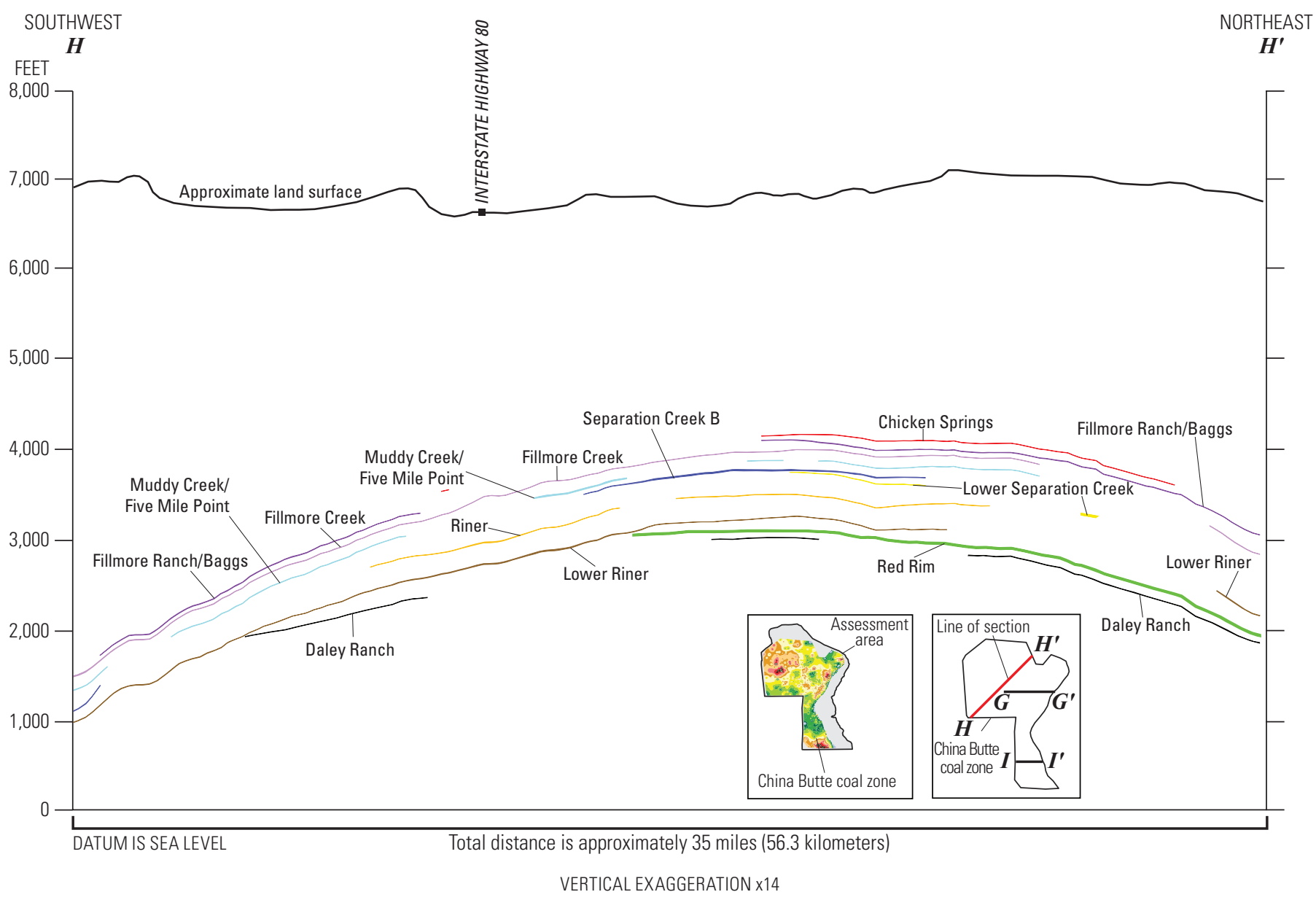

Figure 57. Southwest-northeast cross section $H-H^{\prime}$ showing approximate subsurface distribution of coal beds in the China Butte coal zone in the Little Snake River coal field and Red Desert assessment area, Greater Green River Basin, Wyoming. 


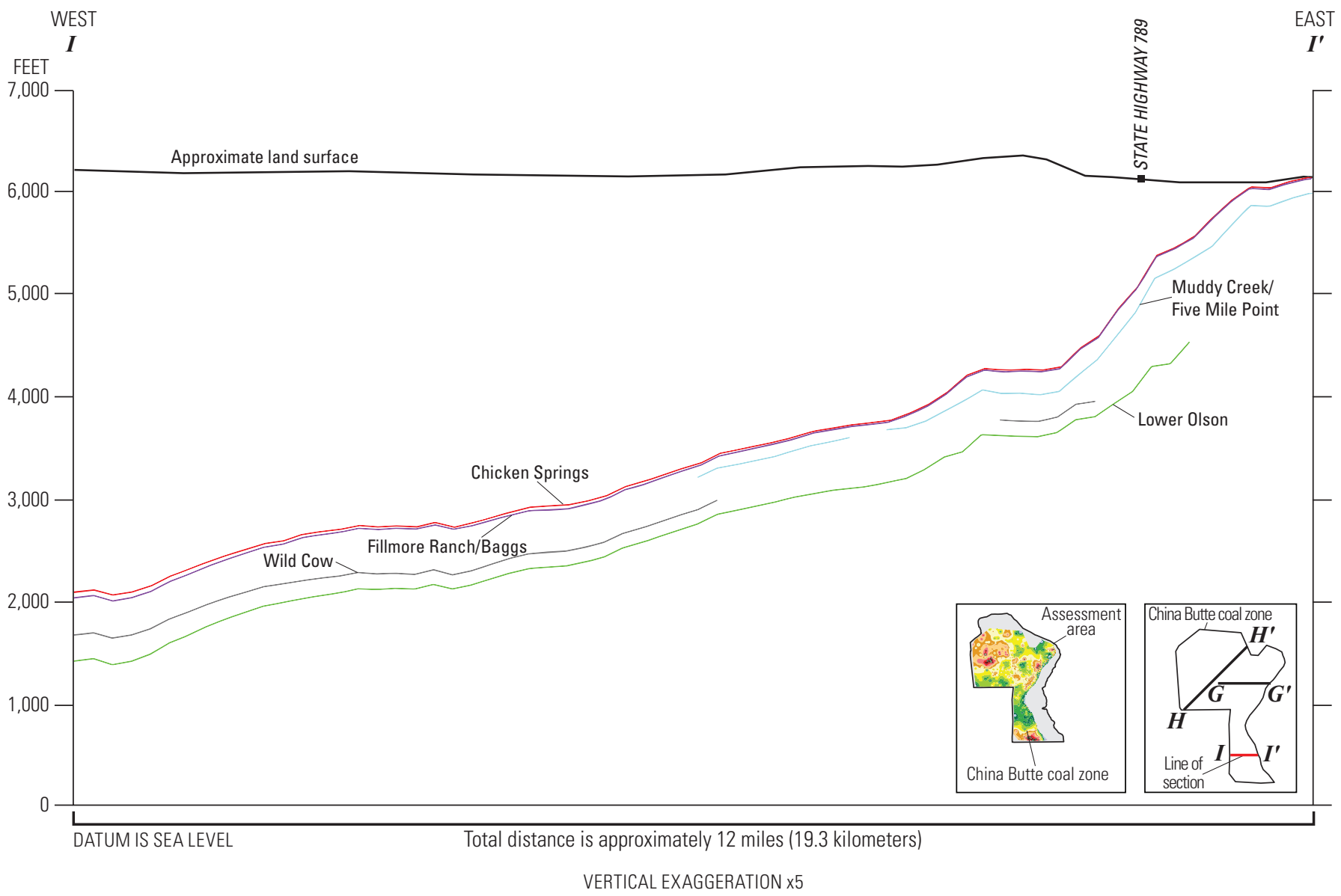

Figure 58. West-east cross section $I-I^{\prime}$ showing approximate subsurface distribution of coal beds in the China Butte coal zone in the Little Snake River coal field and Red Desert assessment area, Greater Green River Basin, Wyoming. 


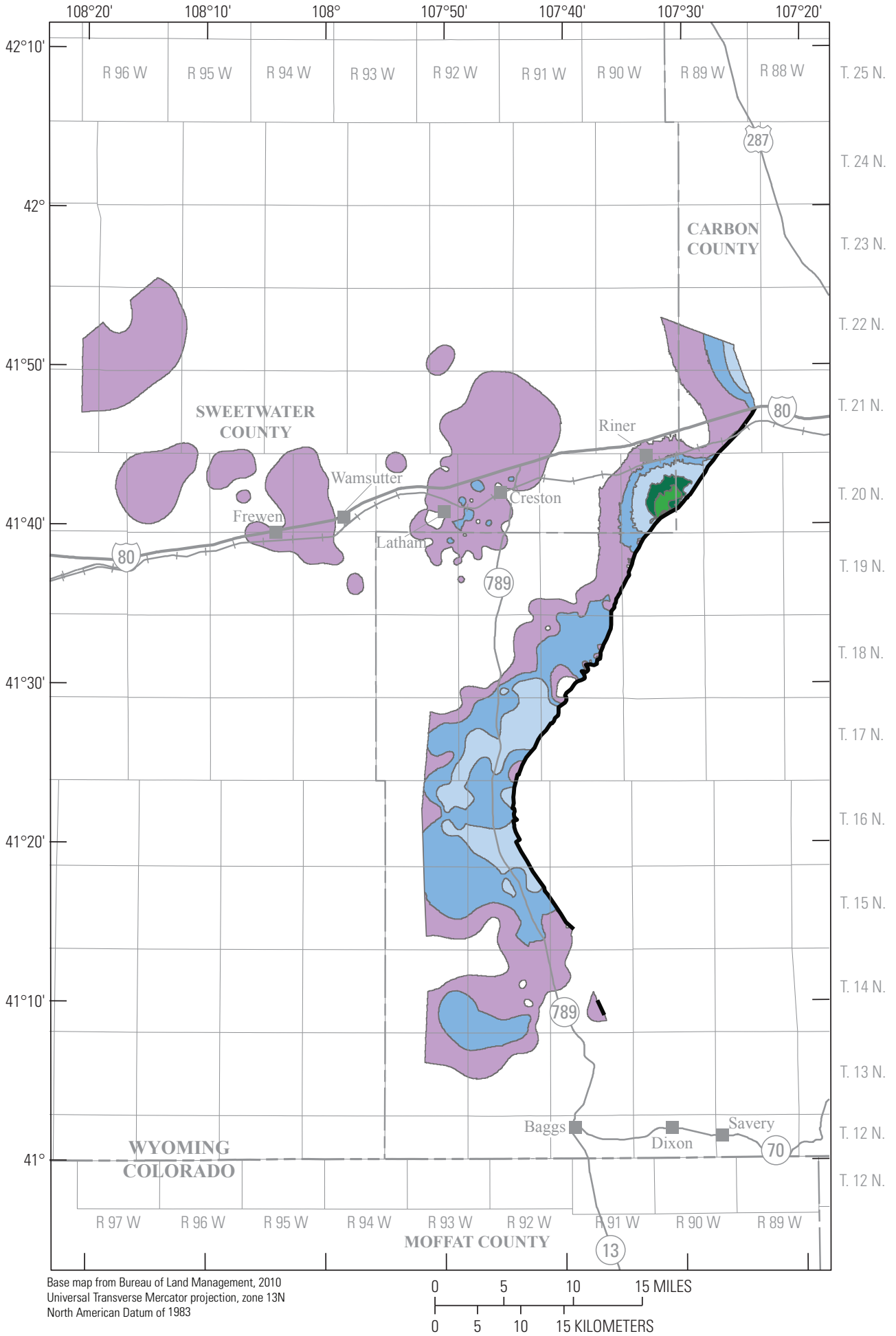

\section{EXPLANATION}

Chicken Springs coal bed isopach, in feet

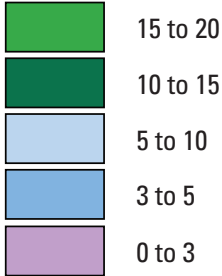

Crop line

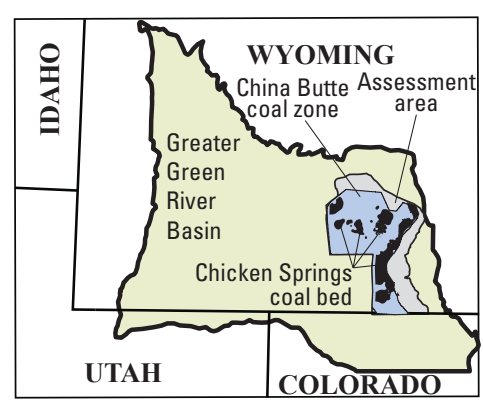

Figure 59. Chicken Springs coal bed showing extent of coal within the Little Snake River coal field and Red Desert assessment area, Greater Green River Basin, Wyoming. 


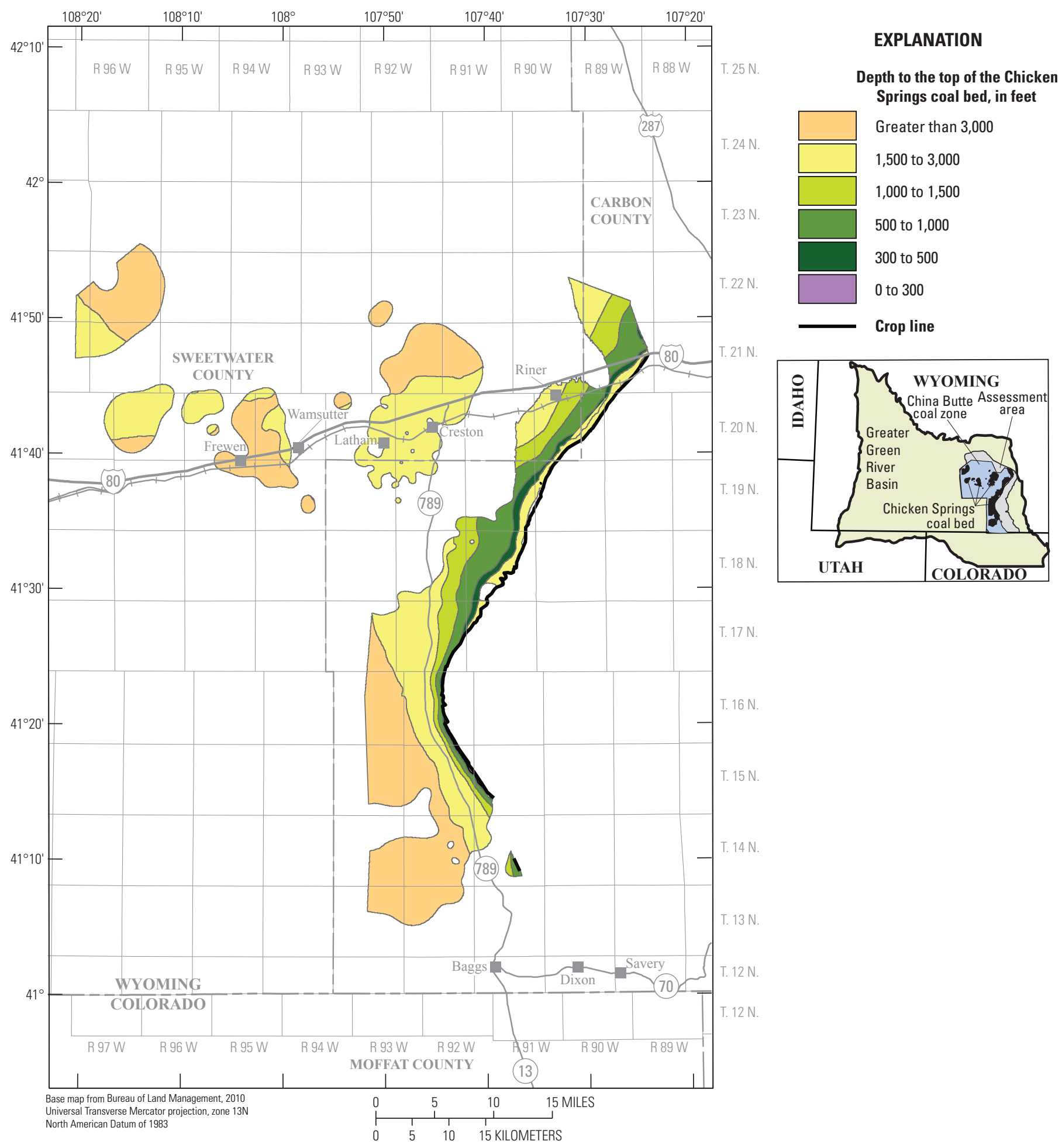

Figure 60. Depth to the top of the Chicken Springs coal bed within the Little Snake River coal field and Red Desert assessment area, Greater Green River Basin, Wyoming. 


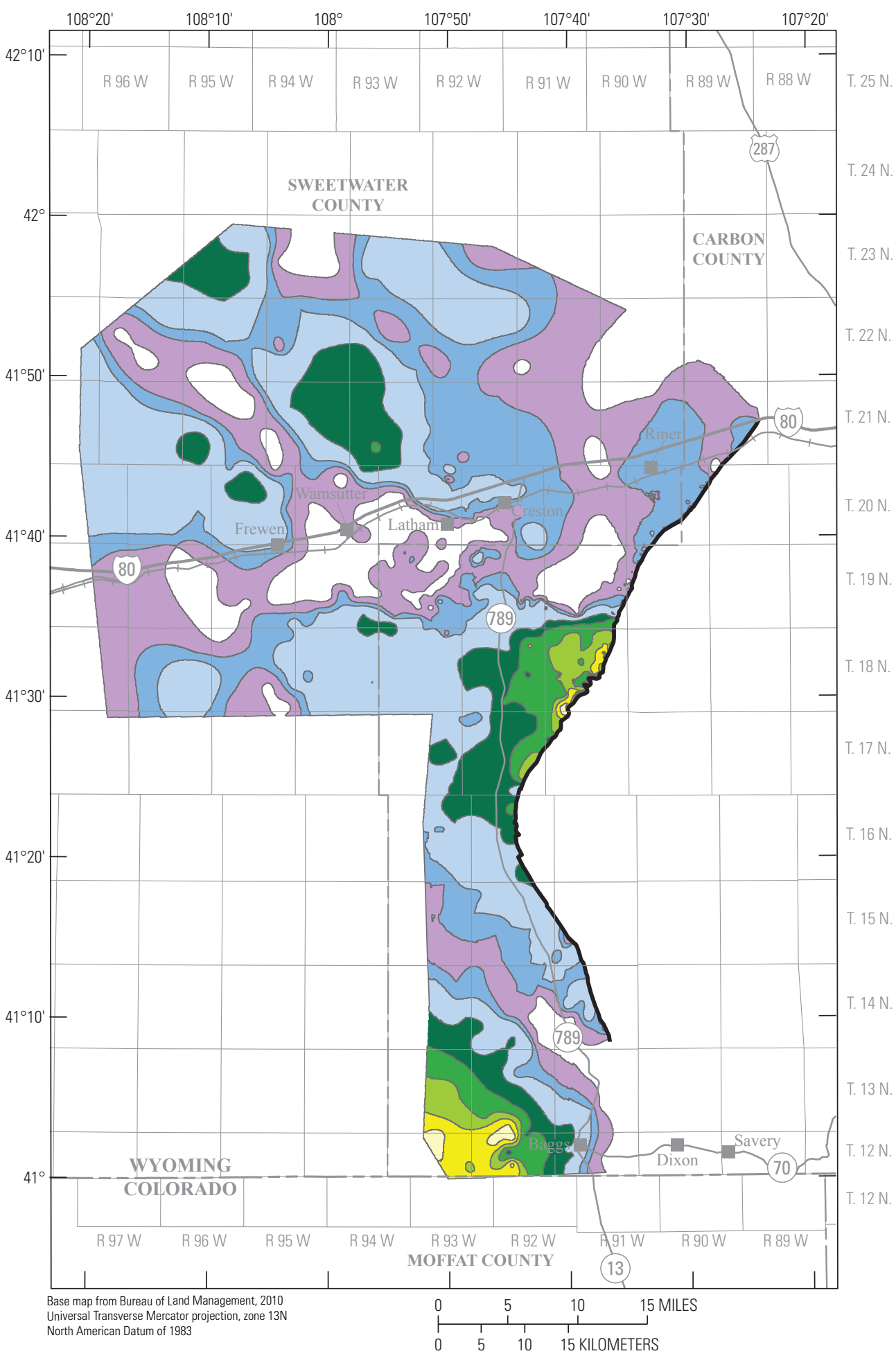

EXPLANATION

Fillmore Ranch/Baggs coal bed isopach, in feet

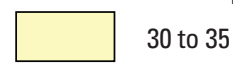

25 to 30

20 to 25

15 to 20

10 to 15

5 to 10

3 to 5

0 to 3

Crop line

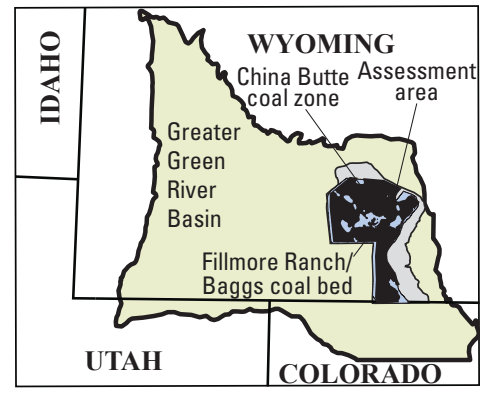

Figure 61. Fillmore Ranch/Baggs coal bed showing extent of coal within the Little Snake River coal field and Red Desert assessment area, Greater Green River Basin, Wyoming. 


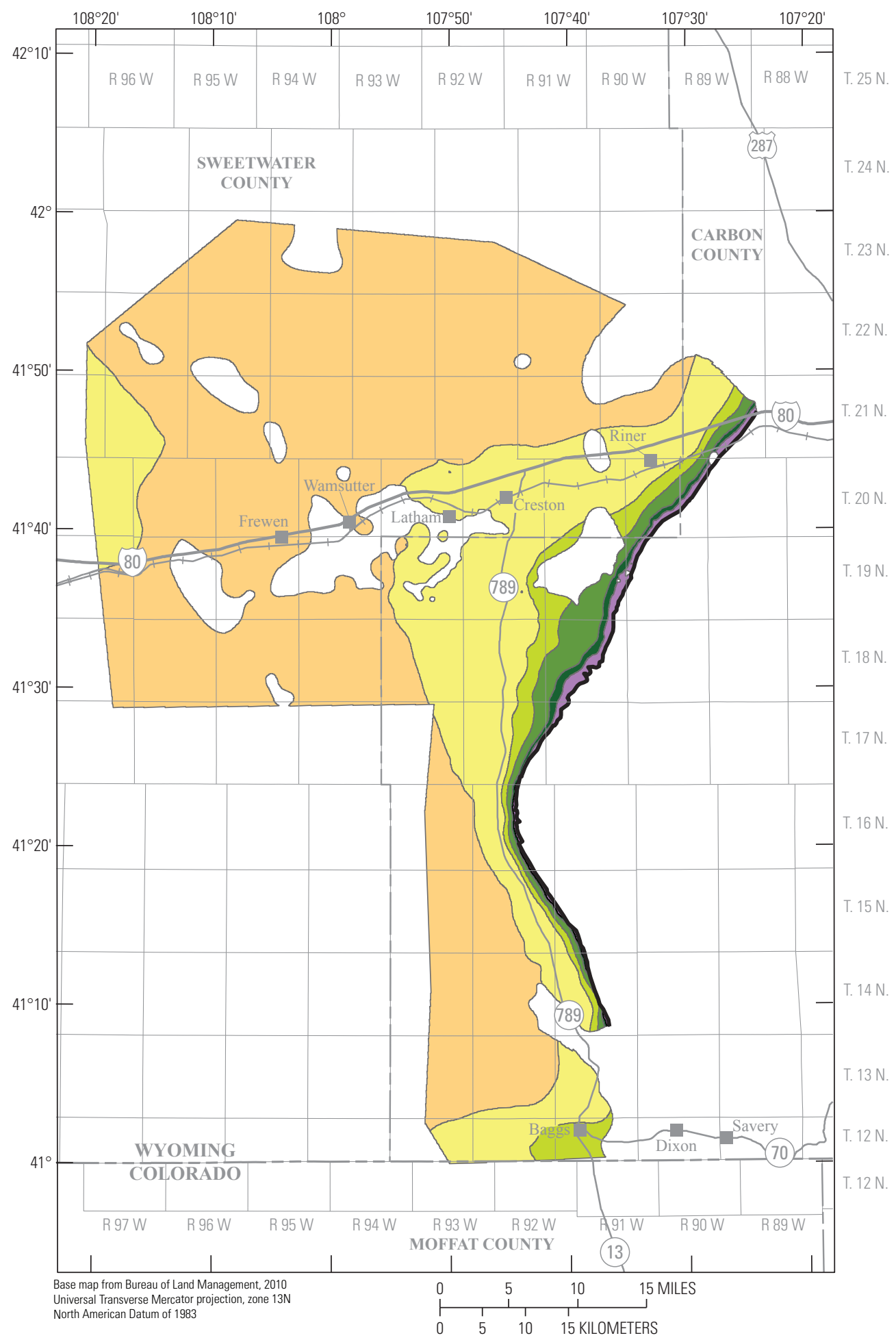

EXPLANATION

Depth to the top of the Fillmore Ranch/Baggs coal bed, in feet

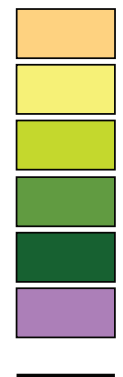

Greater than 3,000

1,500 to 3,000

1,000 to 1,500

500 to 1,000

300 to 500

0 to 300

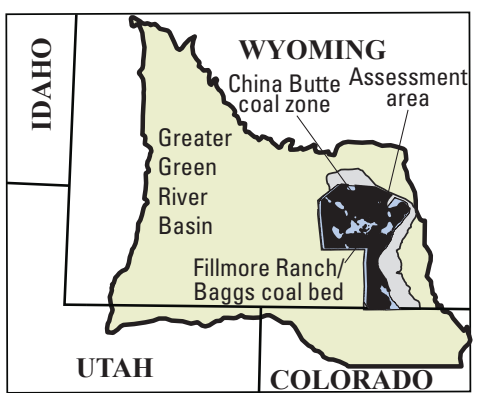

Figure 62. Depth to the top of the Fillmore Ranch/Baggs coal bed within the Little Snake River coal field and Red Desert assessment area, Greater Green River Basin, Wyoming. 


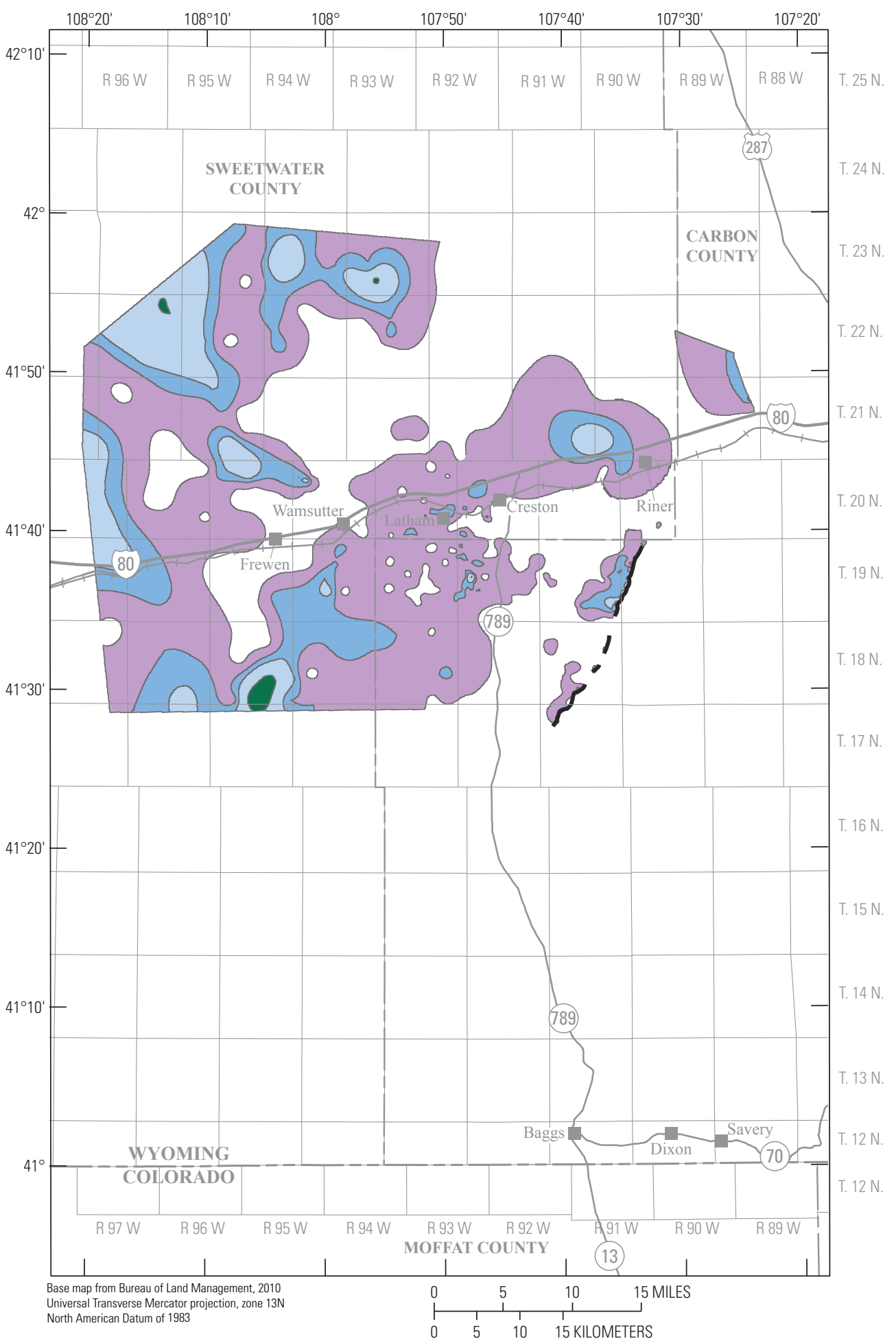

Figure 63. Fillmore Creek coal bed showing extent of coal within the Little Snake River coal field and Red Desert assessment area, Greater Green River Basin, Wyoming. 


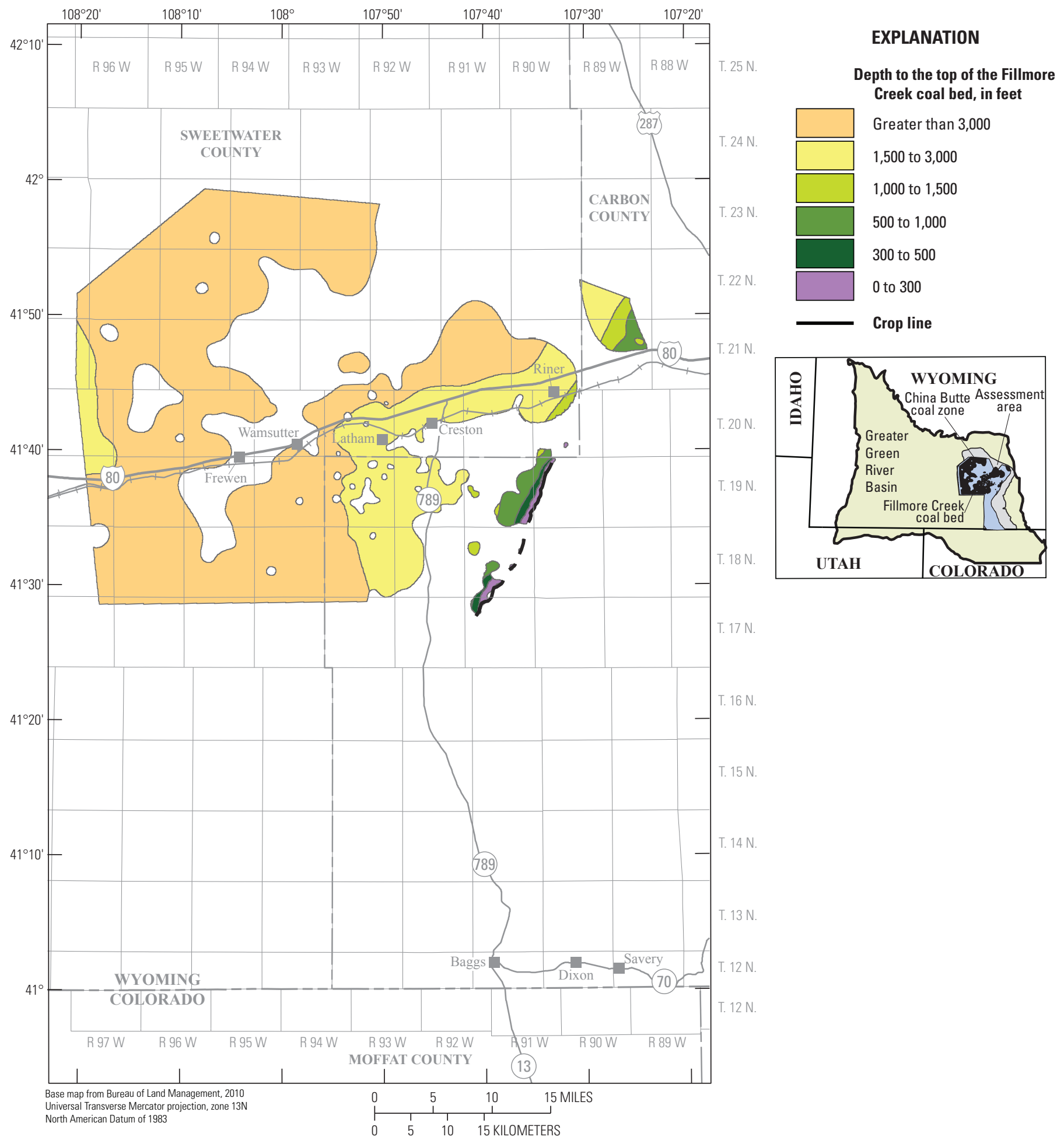

Figure 64. Depth to the top of the Fillmore Creek coal bed within the Little Snake River coal field and Red Desert assessment area, Greater Green River Basin, Wyoming. 


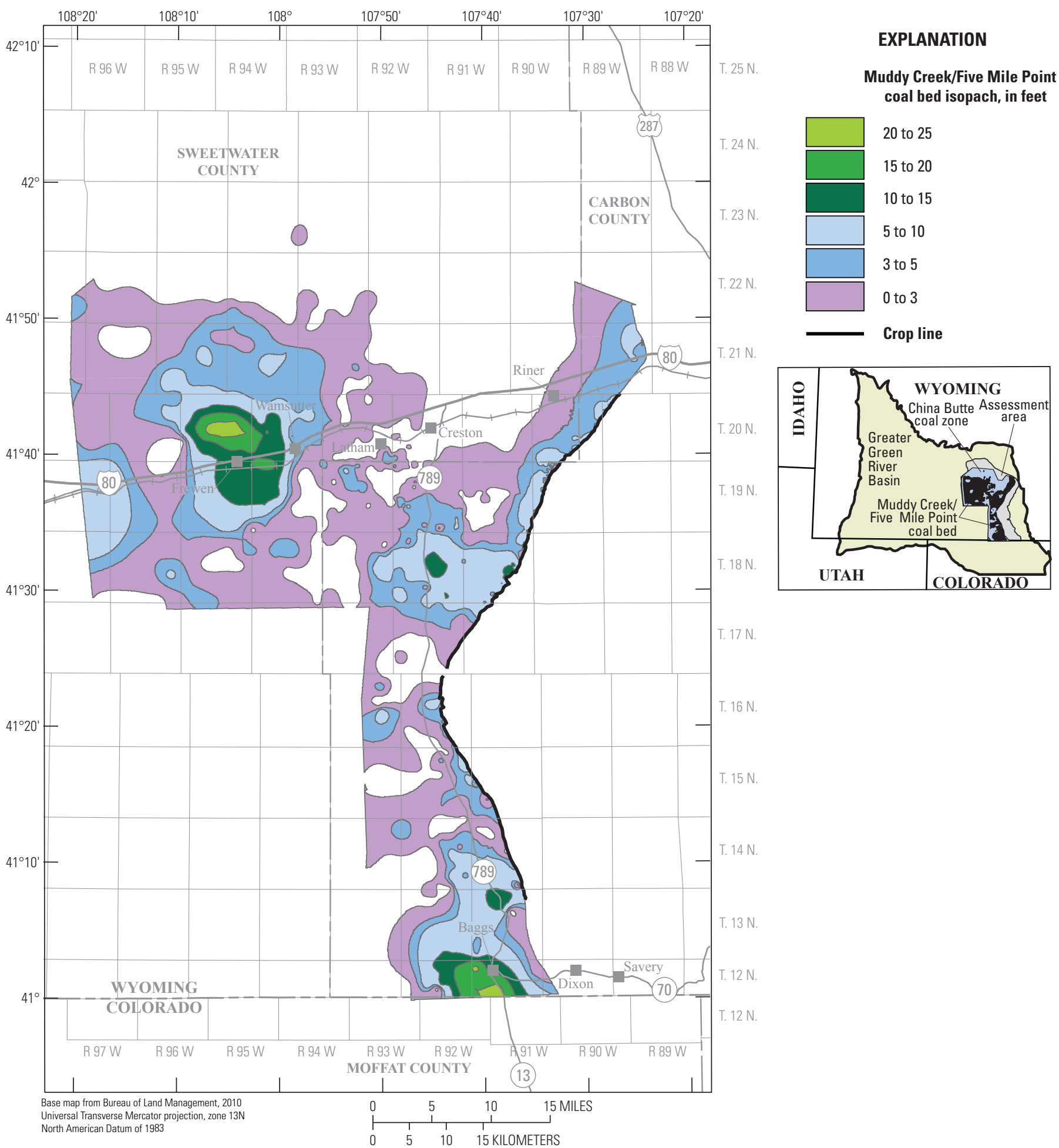

Figure 65. Muddy Creek/Five Mile Point coal bed showing extent of coal within the Little Snake River coal field and Red Desert assessment area, Greater Green River Basin, Wyoming. 


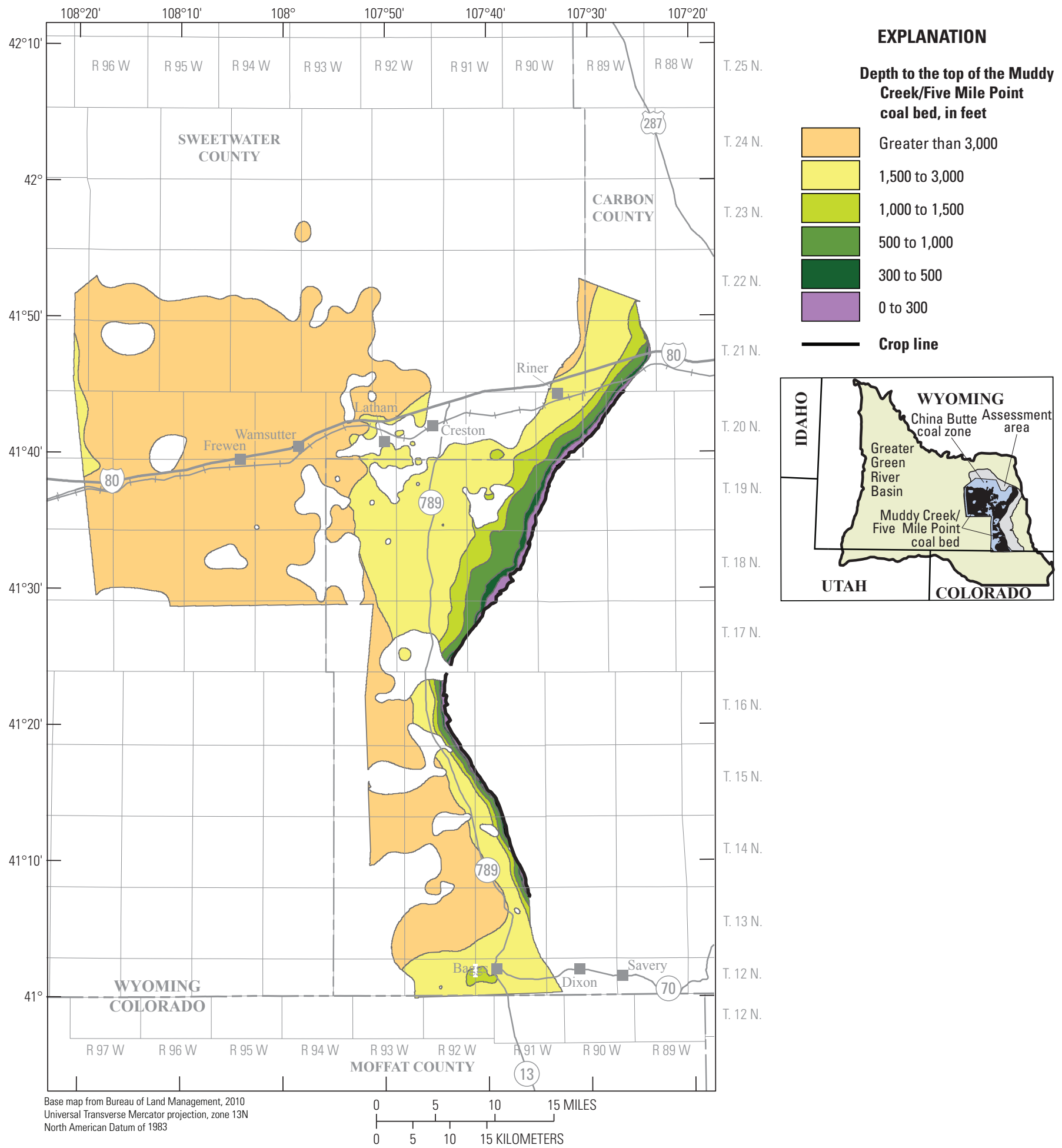

Figure 66. Depth to the top of the Muddy Creek/Five Mile Point coal bed within the Little Snake River coal field and Red Desert assessment area, Greater Green River Basin, Wyoming. 


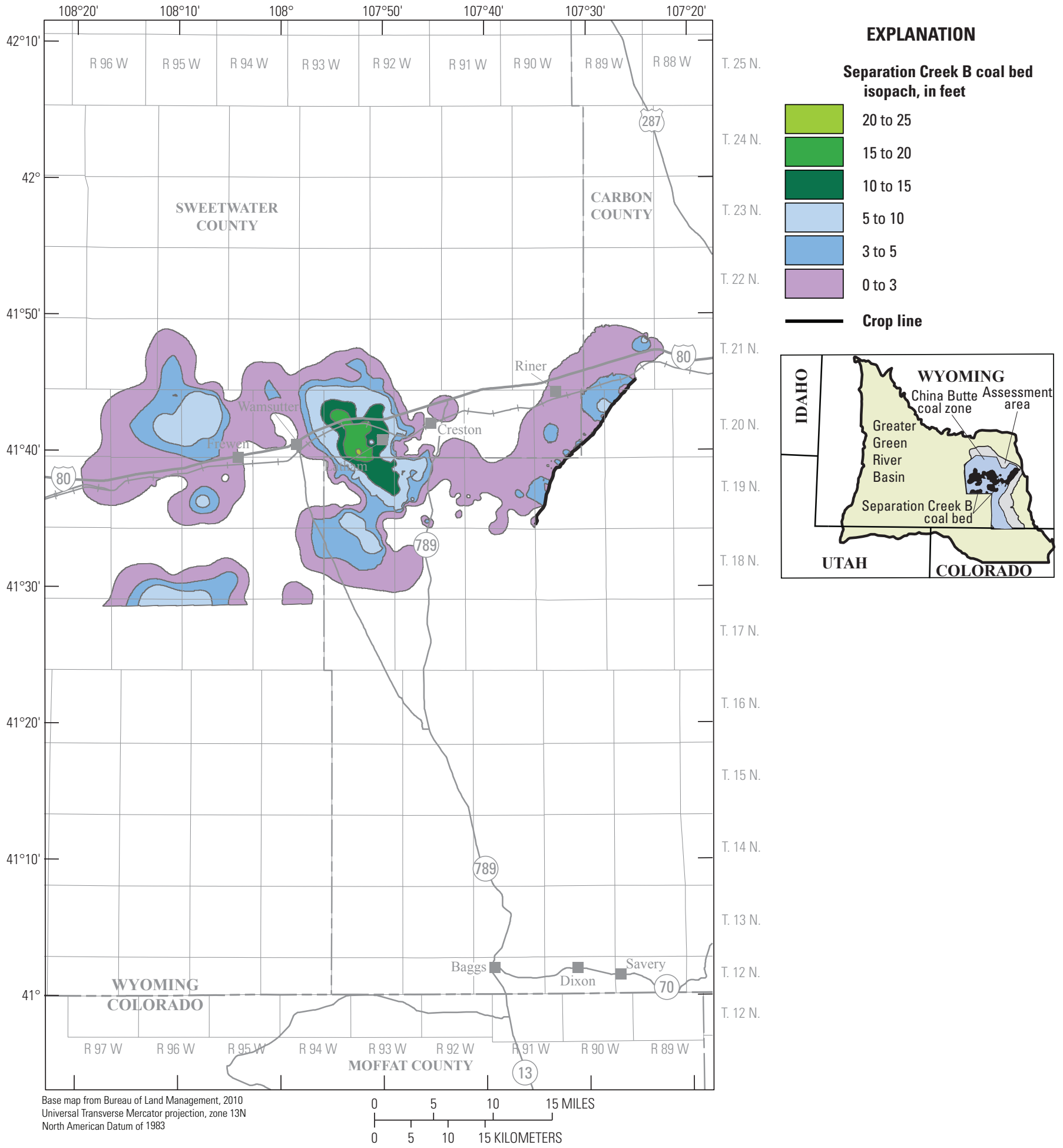

Figure 67. Separation Creek B coal bed showing extent of coal within the Little Snake River coal field and Red Desert assessment area, Greater Green River Basin, Wyoming. 


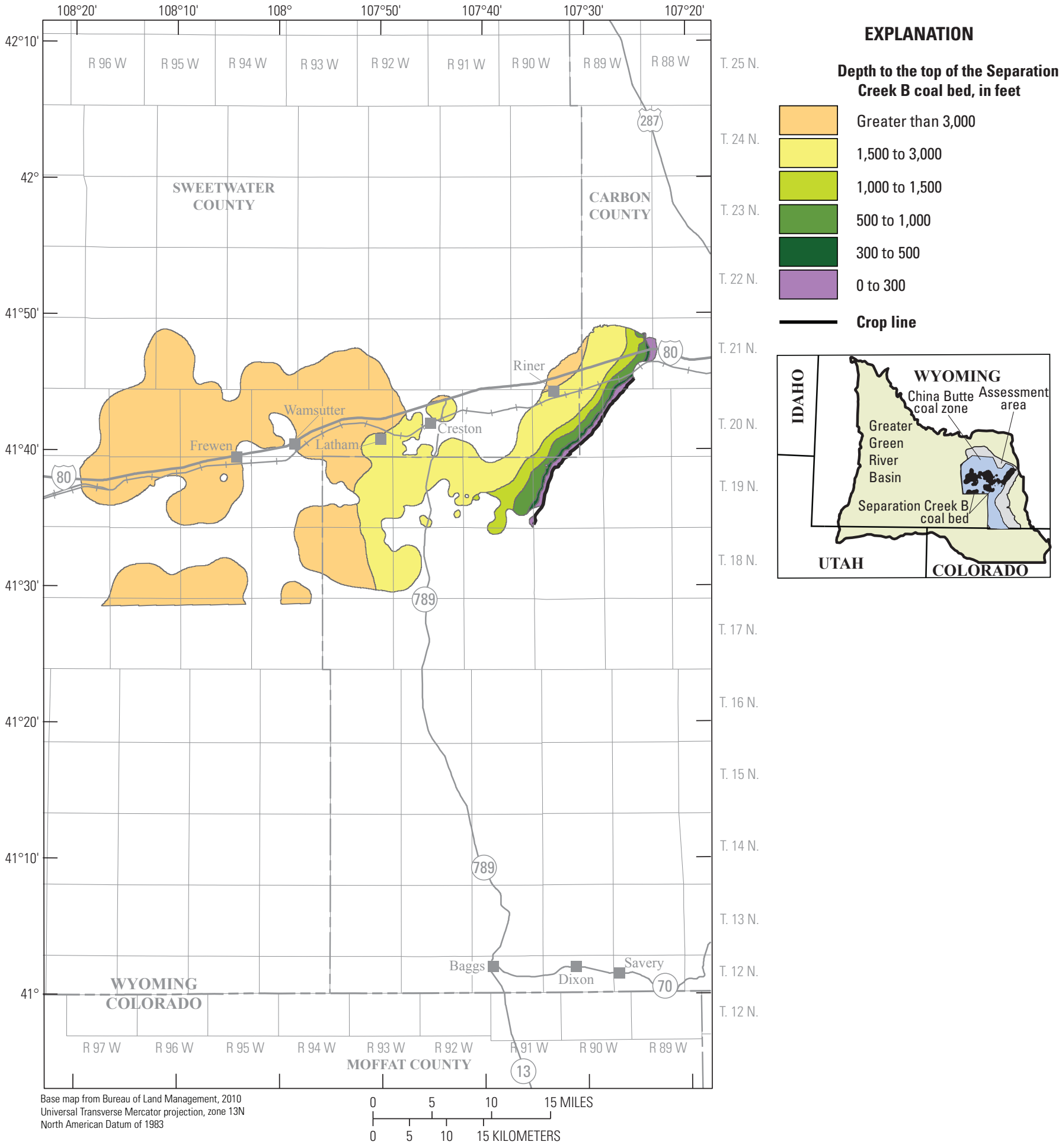

Figure 68. Depth to the top of the Separation Creek B coal bed within the Little Snake River coal field and Red Desert assessment area, Greater Green River Basin, Wyoming. 


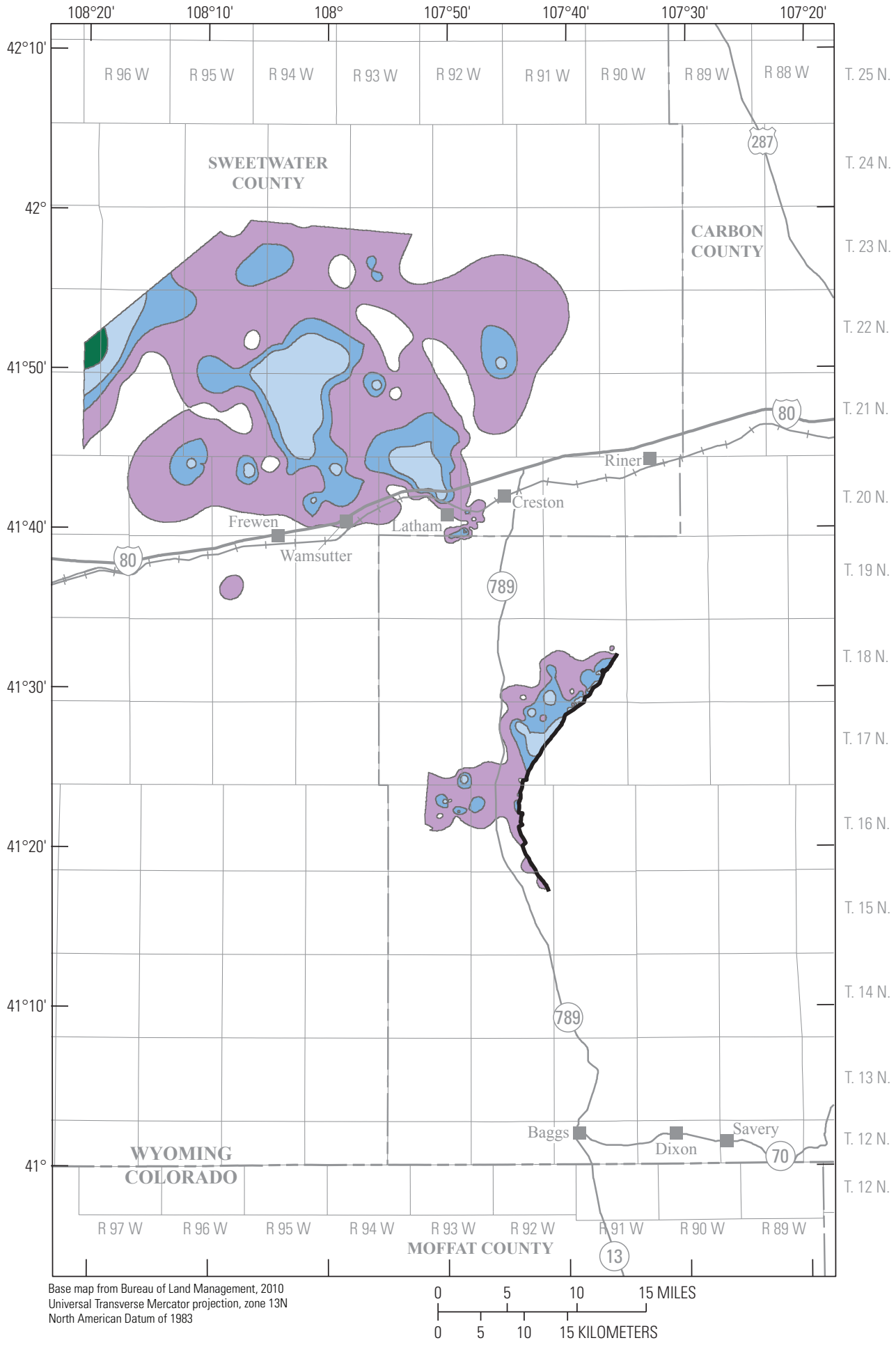

Figure 69. Lower Separation Creek coal bed showing extent of coal within the Little Snake River coal field and Red Desert assessment area, Greater Green River Basin, Wyoming. 


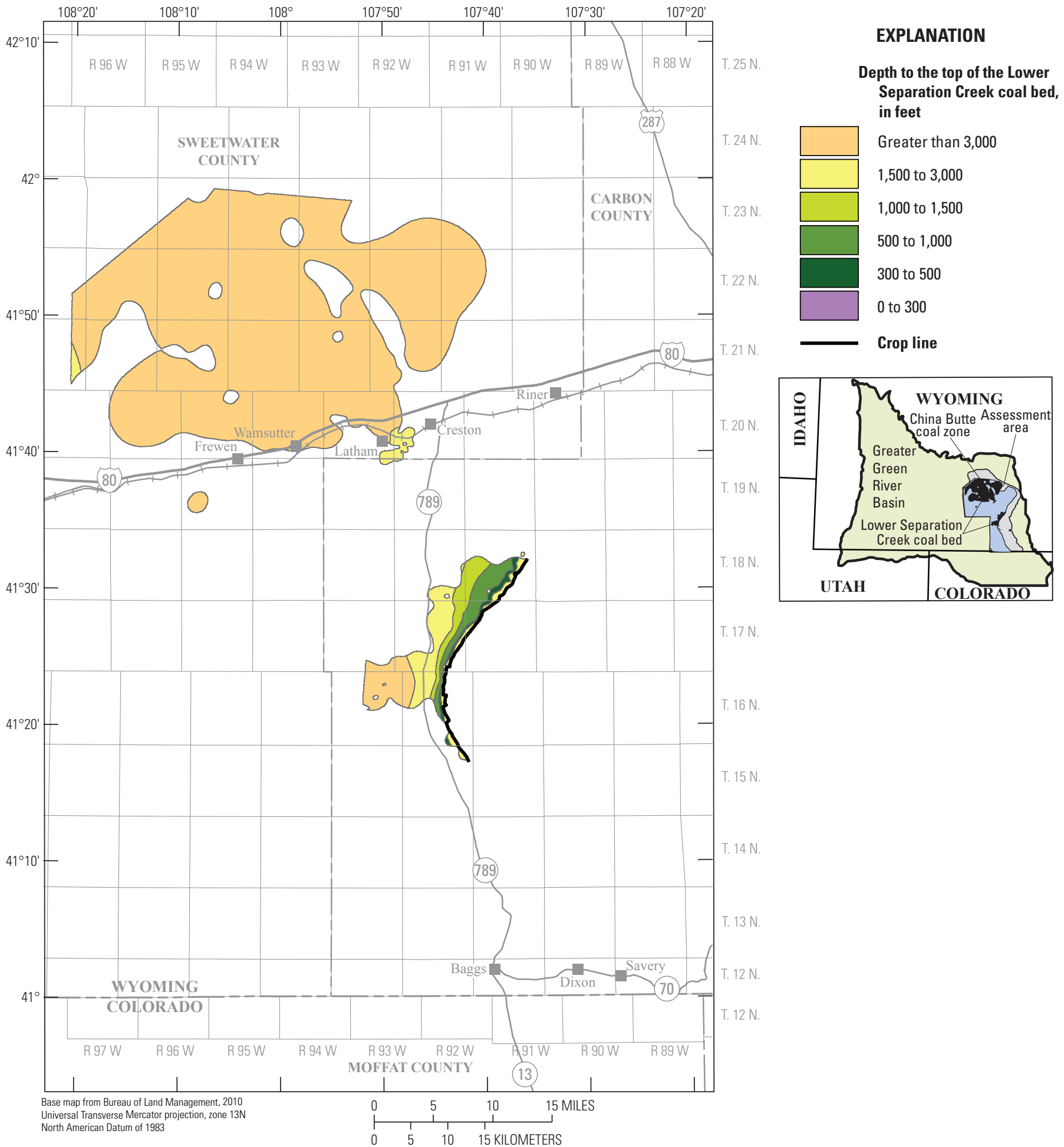

Figure 70. Depth to the top of the Lower Separation Creek coal bed within the Little Snake River coal field and Red Desert assessment area, Greater Green River Basin, Wyoming. 


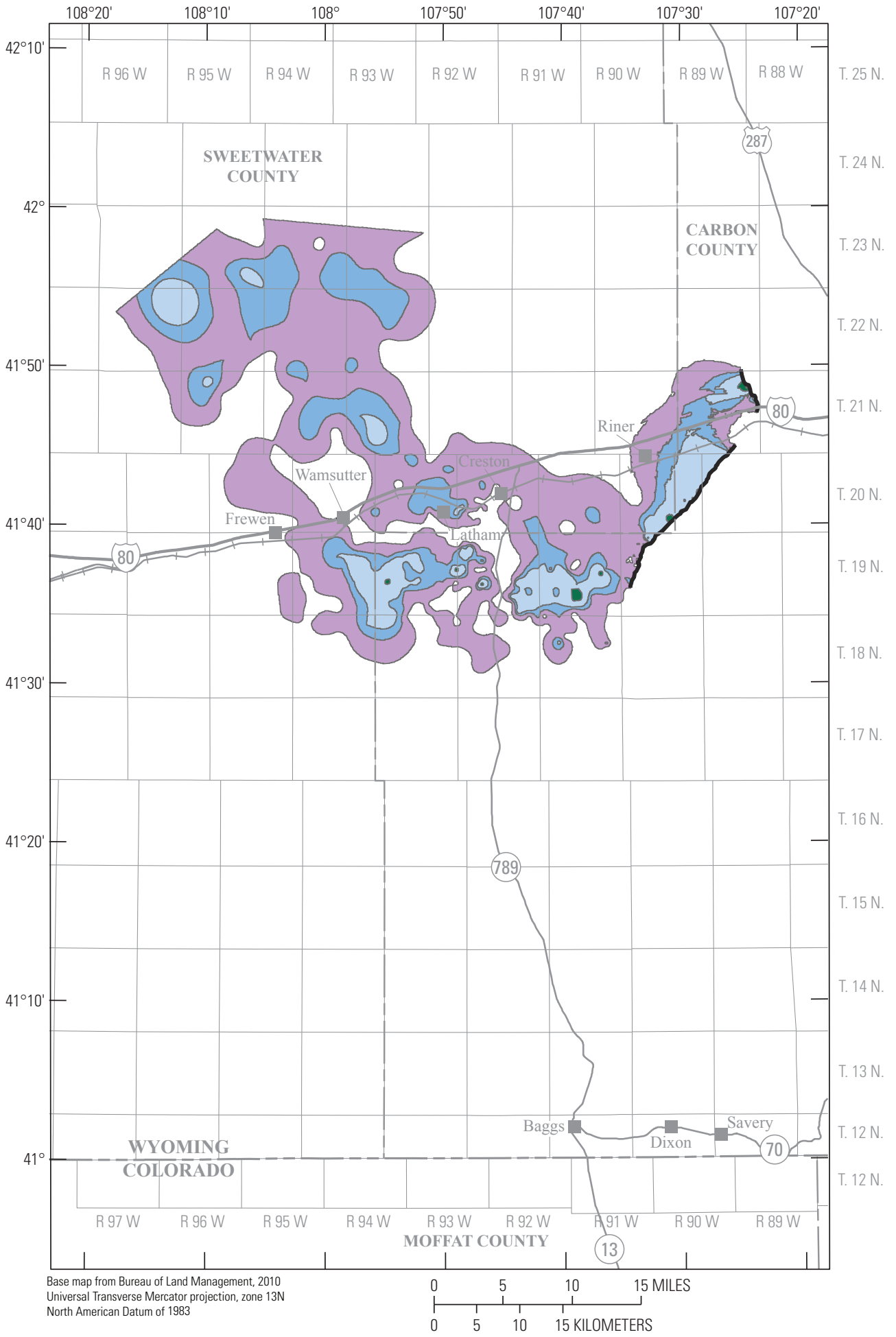

\section{EXPLANATION}
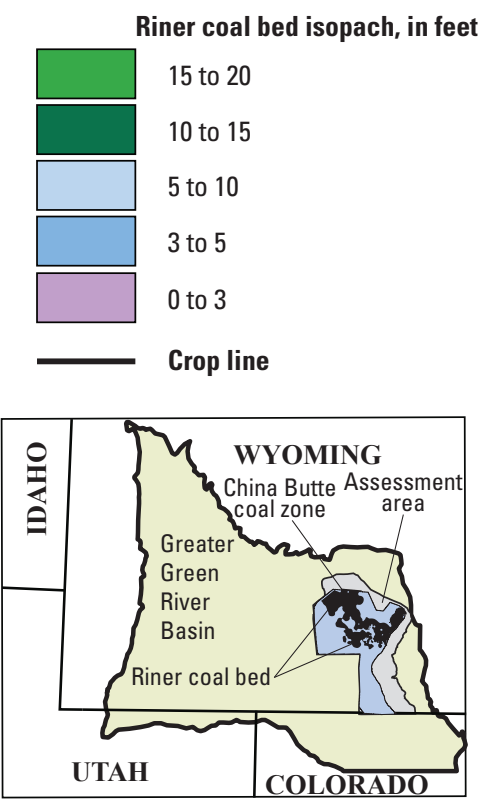

Figure 71. Riner coal bed showing extent of coal within the Little Snake River coal field and Red Desert assessment area, Greater Green River Basin, Wyoming. 


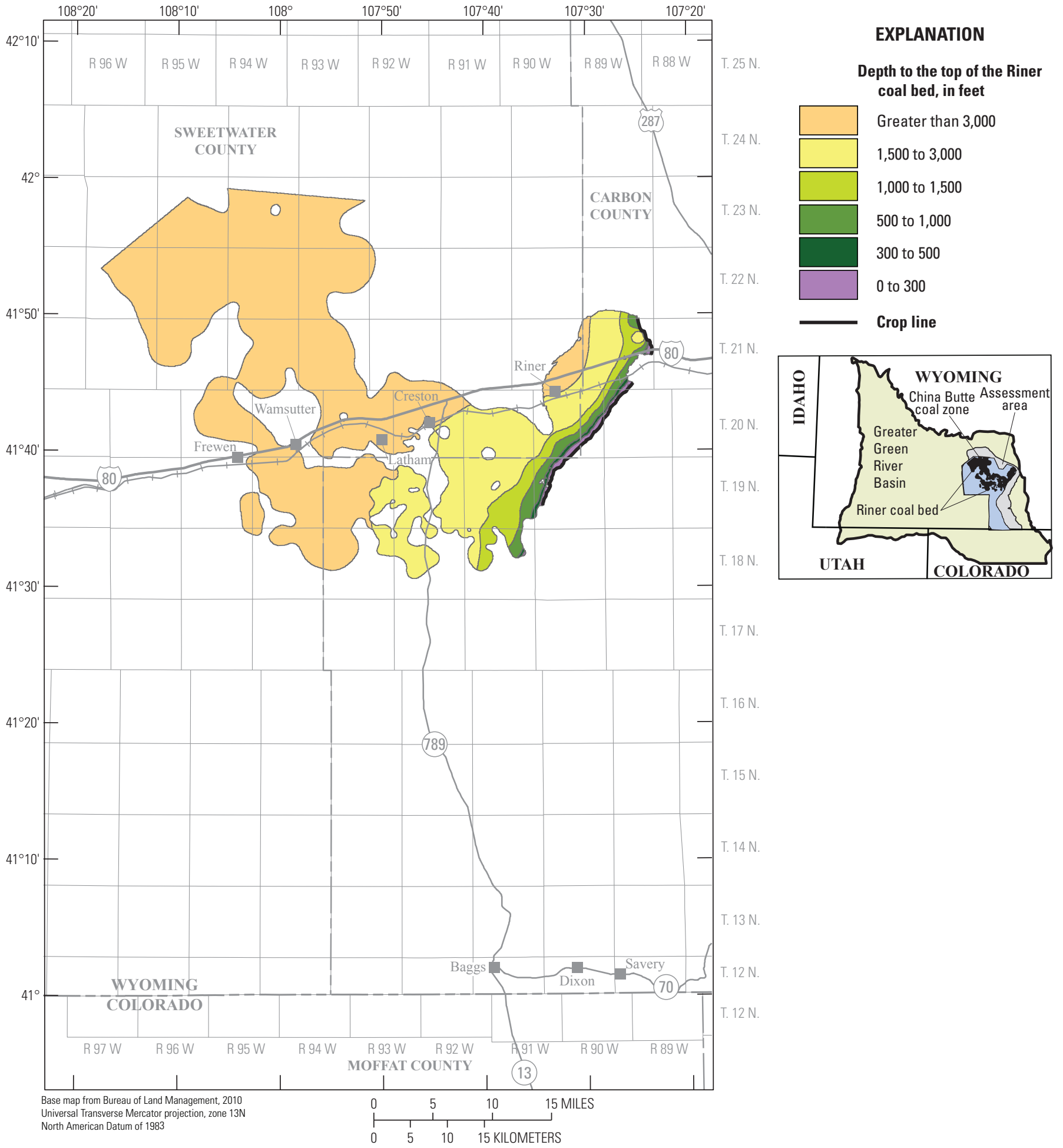

Figure 72. Depth to the top of the Riner coal bed within the Little Snake River coal field and Red Desert assessment area, Greater Green River Basin, Wyoming. 


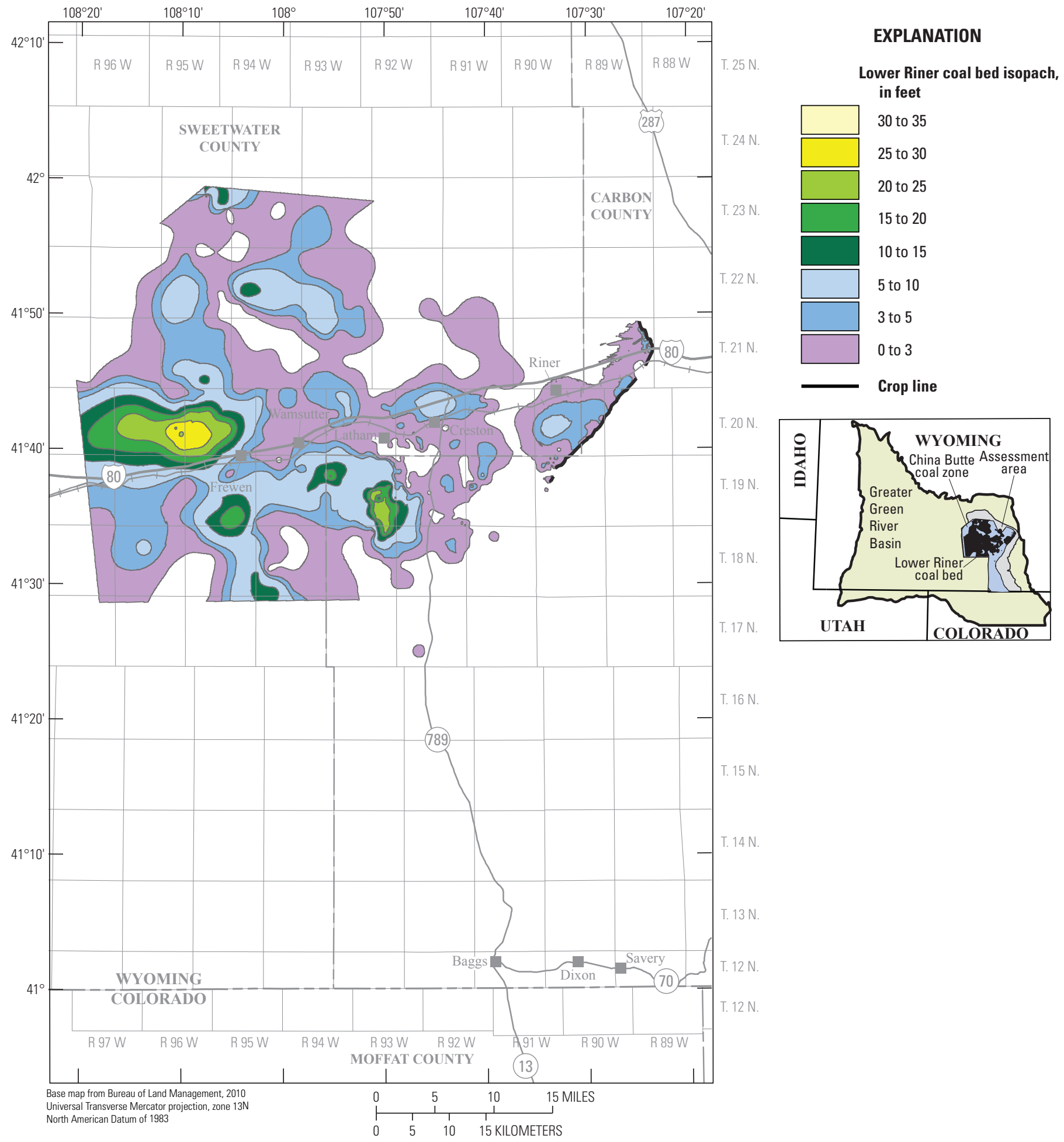

Figure 73. Lower Riner coal bed showing extent of coal within the Little Snake River coal field and Red Desert assessment area, Greater Green River Basin, Wyoming. 


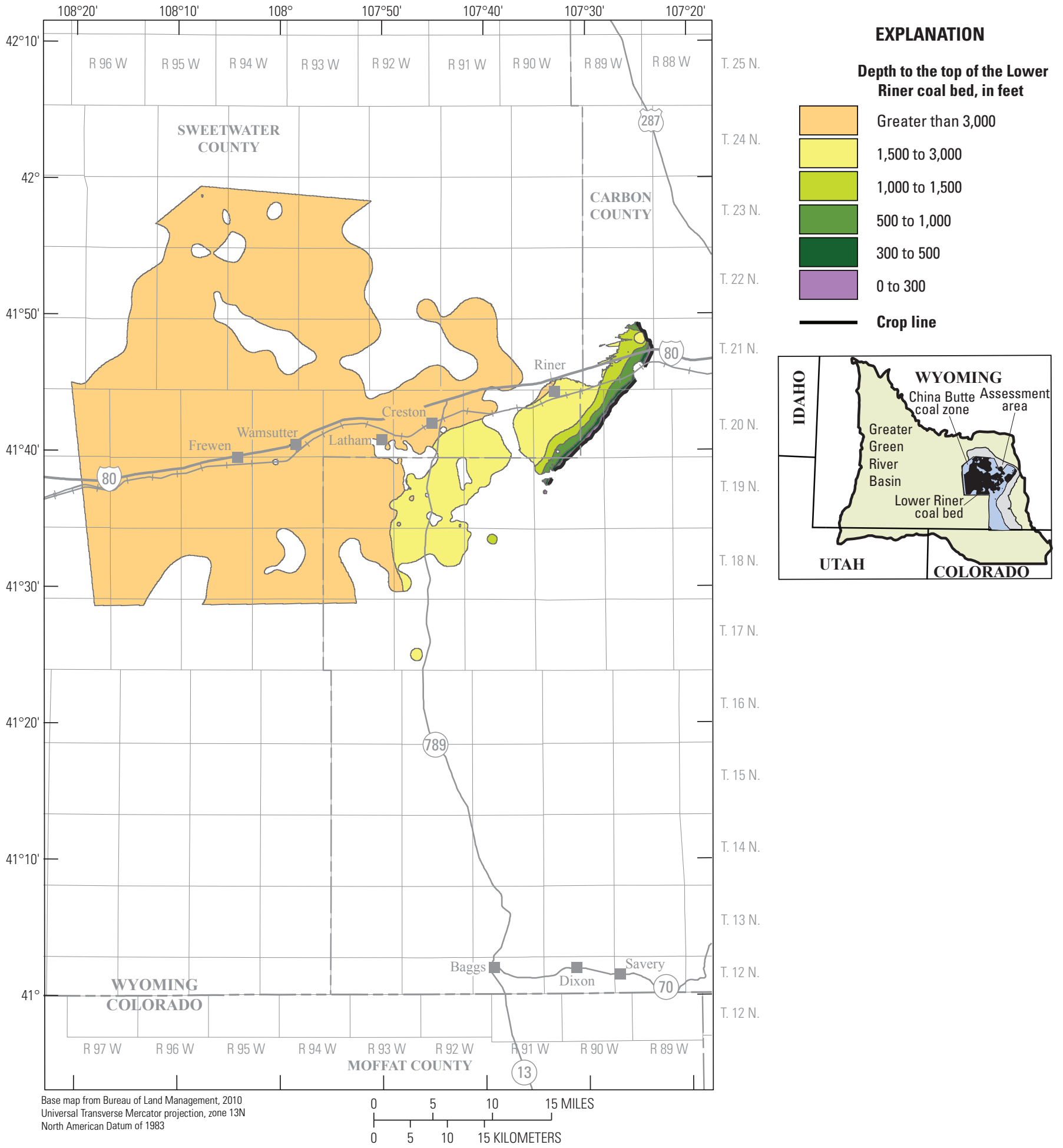

Figure 74. Depth to the top of the Lower Riner coal bed within the Little Snake River coal field and Red Desert assessment area, Greater Green River Basin, Wyoming. 


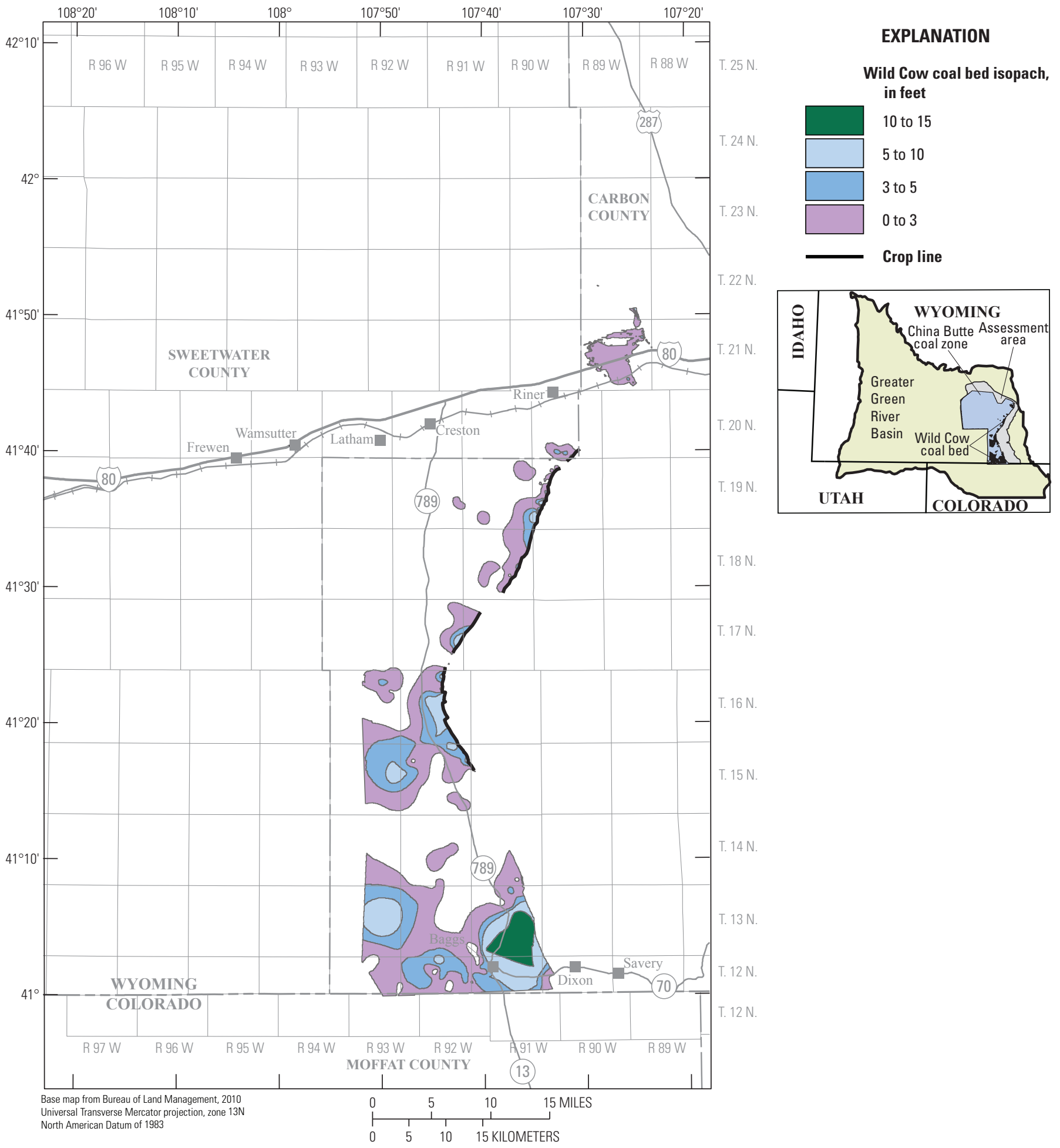

Figure 75. Wild Cow coal bed showing extent of coal within the Little Snake River coal field and Red Desert assessment area, Greater Green River Basin, Wyoming. 


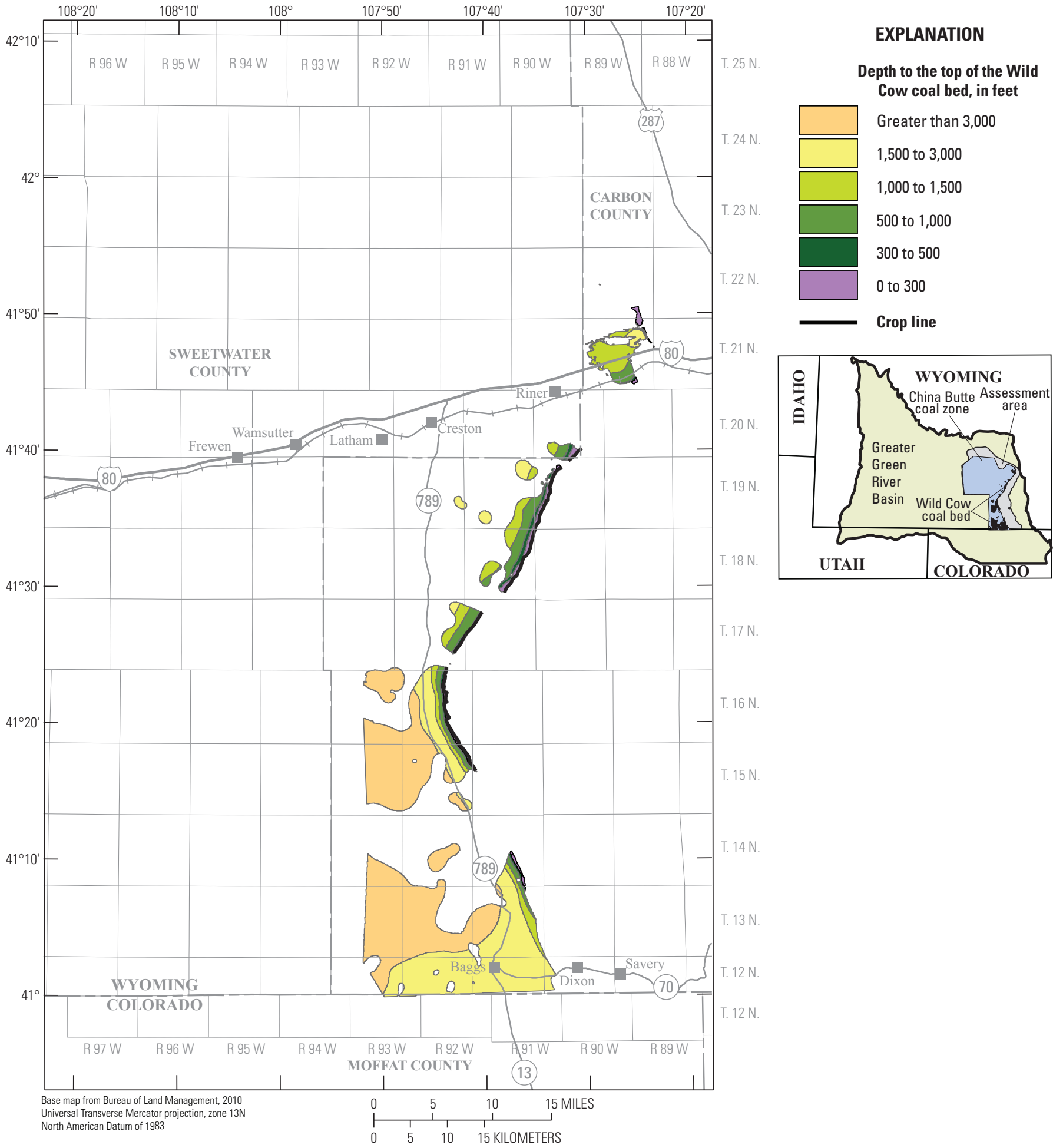

Figure 76. Depth to the top of the Wild Cow coal bed within the Little Snake River coal field and Red Desert assessment area, Greater Green River Basin, Wyoming. 


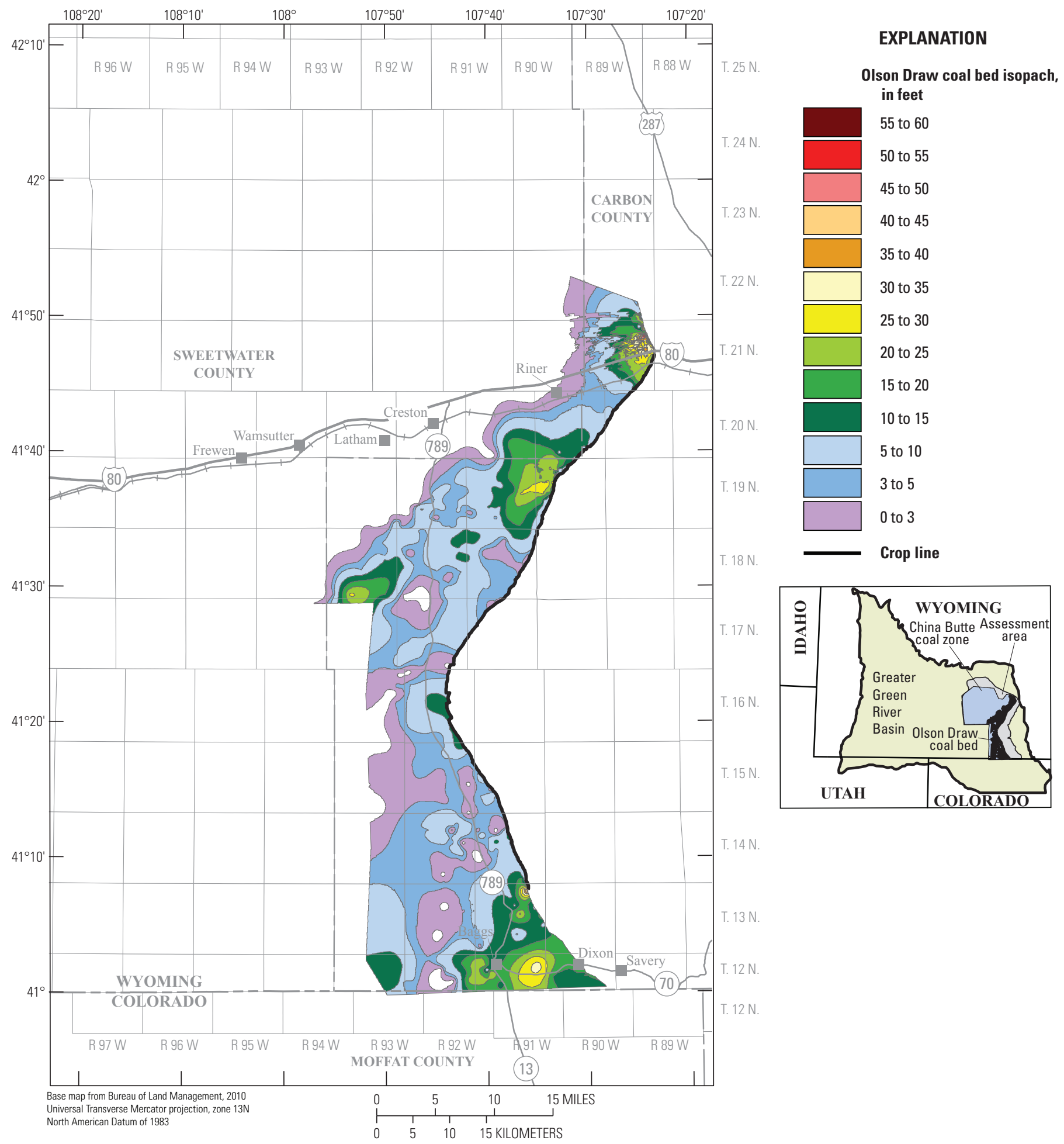

Figure 77. Olson Draw coal bed showing extent of coal within the Little Snake River coal field and Red Desert assessment area, Greater Green River Basin, Wyoming. 


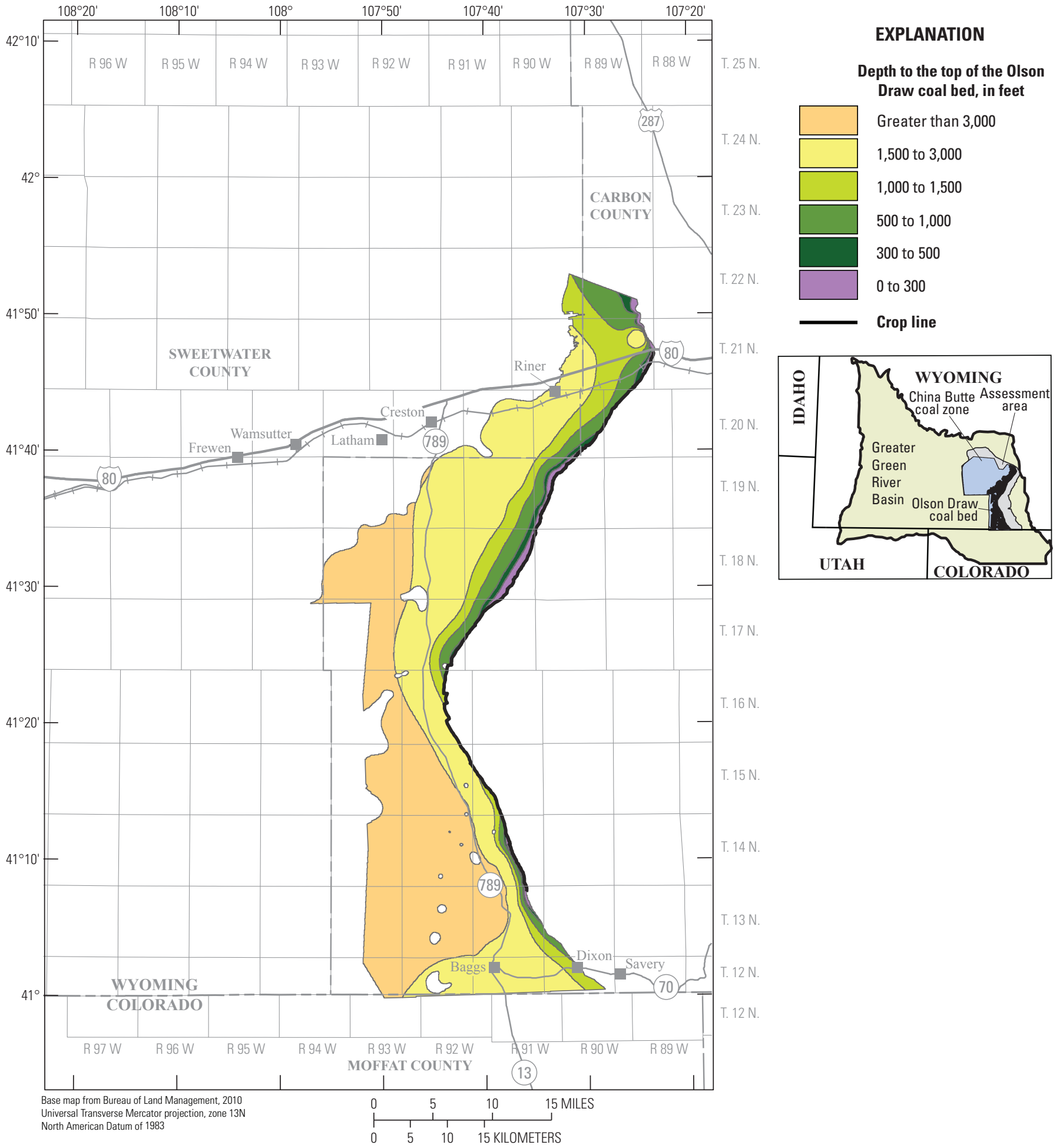

Figure 78. Depth to the top of the Olson Draw coal bed within the Little Snake River coal field and Red Desert assessment area, Greater Green River Basin, Wyoming. 


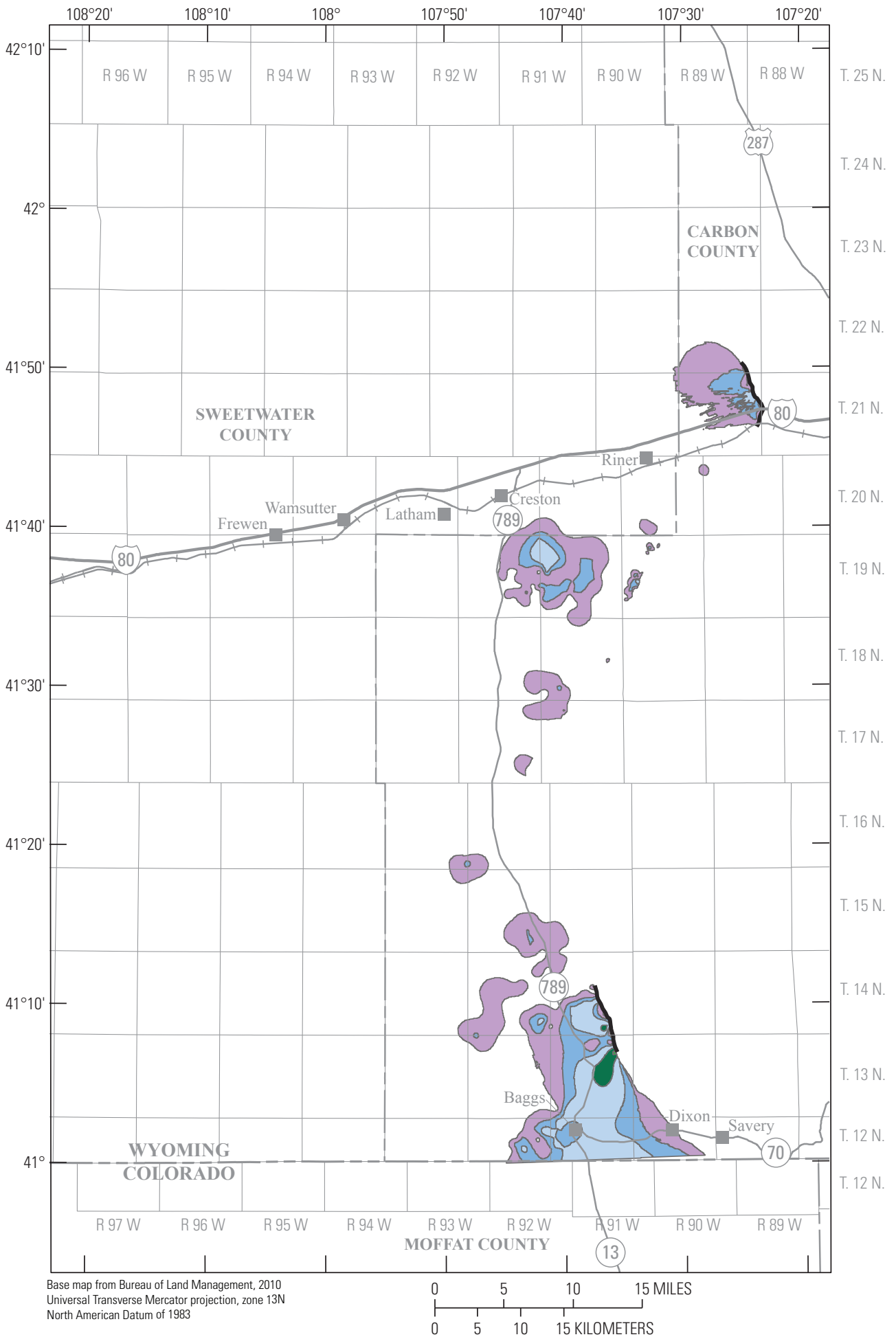

\section{EXPLANATION}

Lower OIson Draw coal bed isopach, in feet

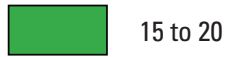

10 to 15

10 to 15

5 to 10

3 to 5

0 to 3

Crop line

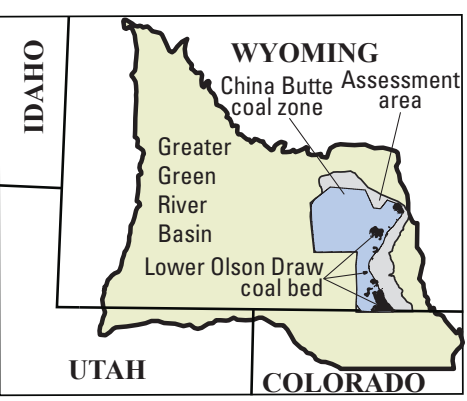

Figure 79. Lower Olson Draw coal bed showing extent of coal within the Little Snake River coal field and Red Desert assessment area, Greater Green River Basin, Wyoming. 


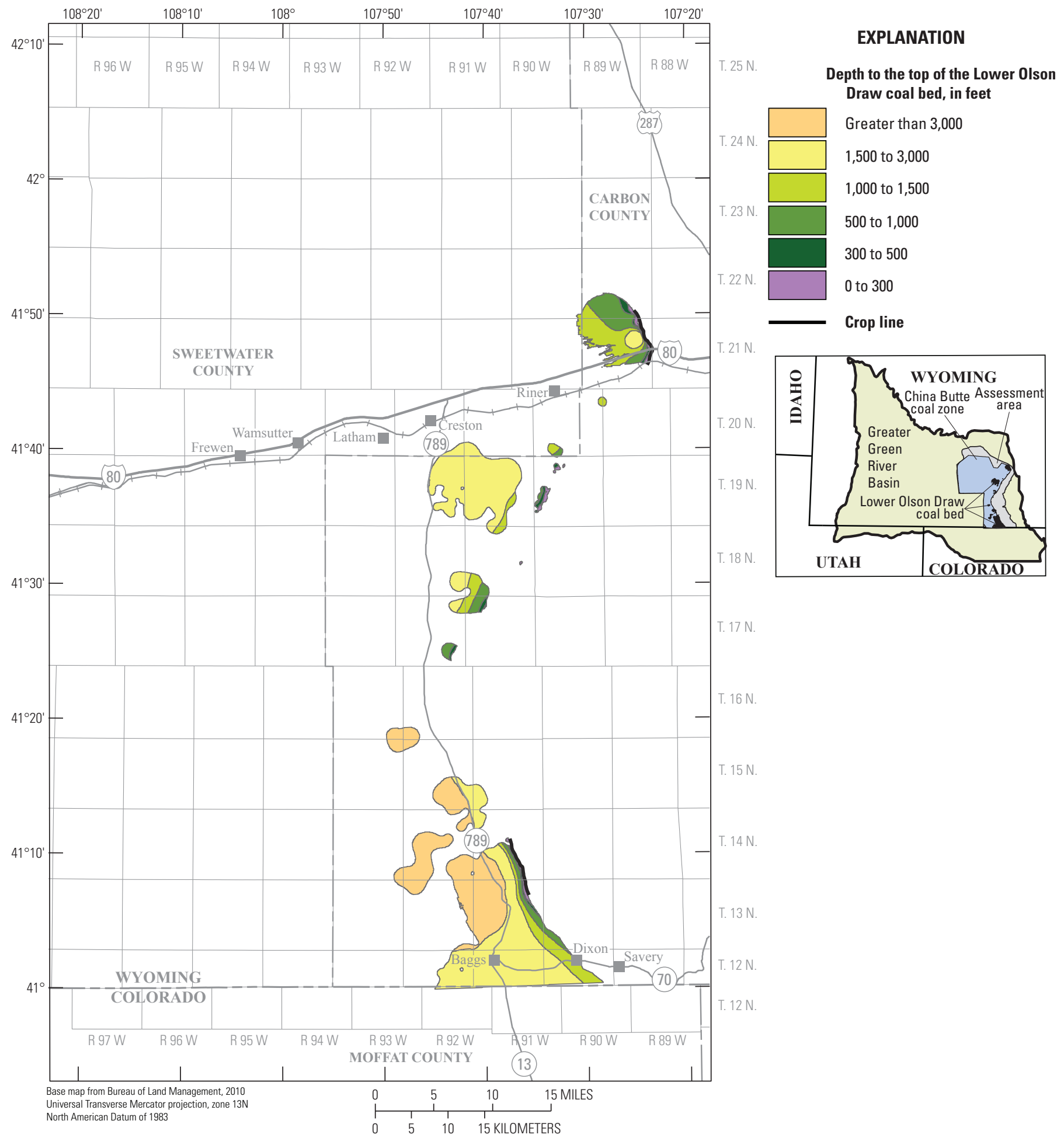

Figure 80. Depth to the top of the Lower Olson Draw coal bed within the Little Snake River coal field and Red Desert assessment area, Greater Green River Basin, Wyoming. 


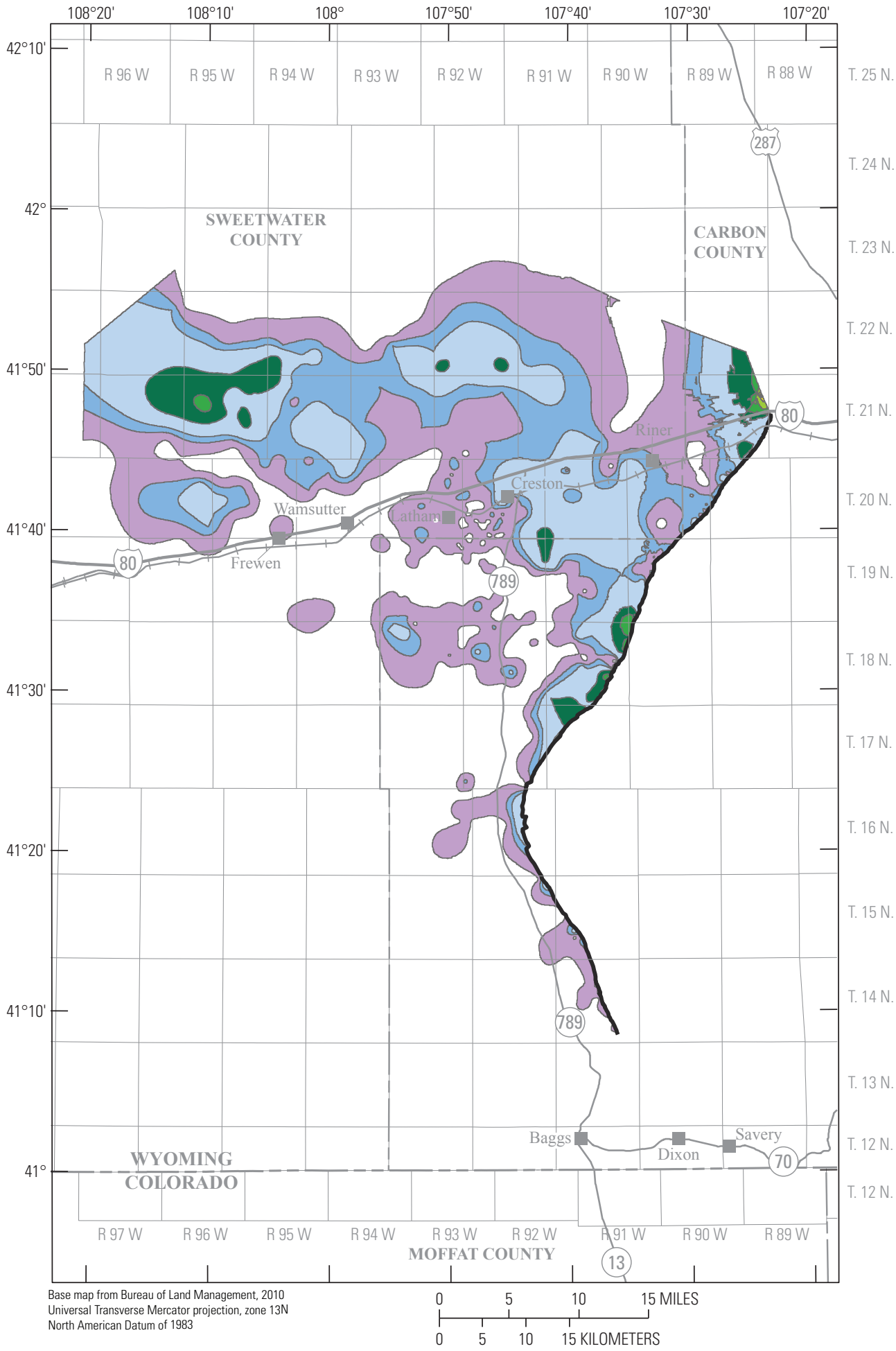

EXPLANATION

Red Rim coal bed isopach, in feet

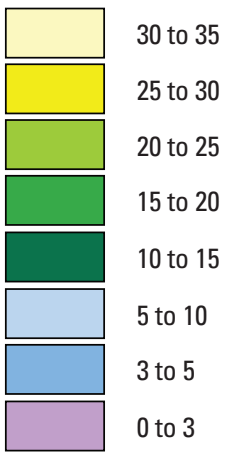

Crop line

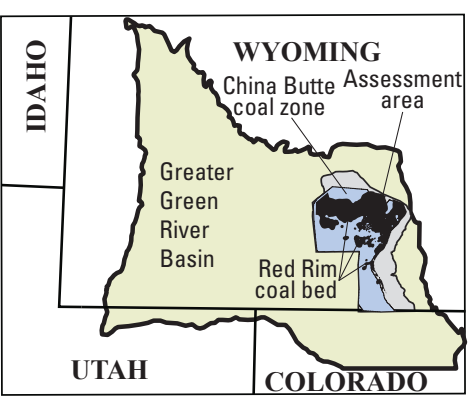

Figure 81. Red Rim coal bed showing extent of coal within the Little Snake River coal field and Red Desert assessment area, Greater Green River Basin, Wyoming. 


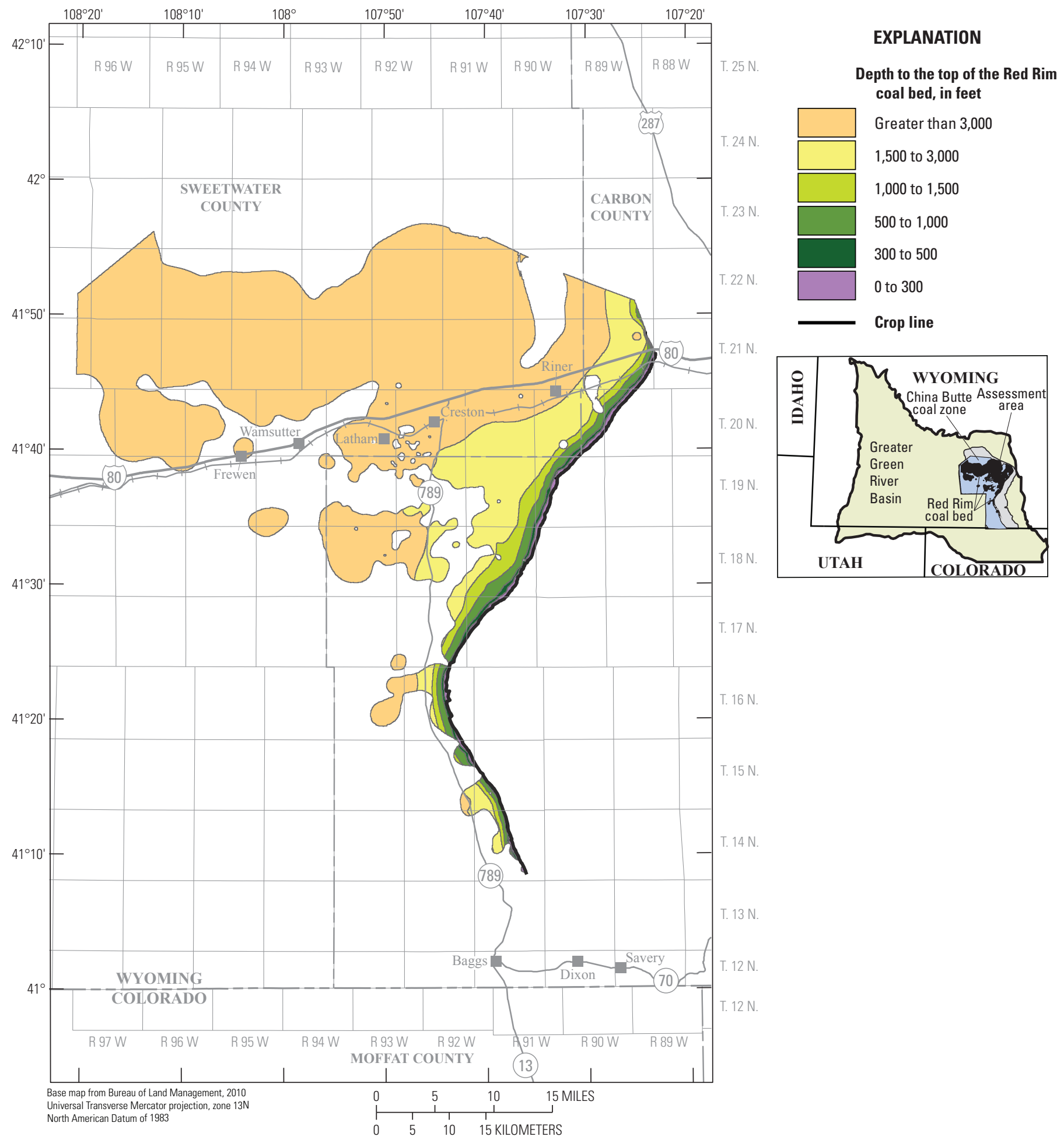

Figure 82. Depth to the top of the Red Rim coal bed within the Little Snake River coal field and Red Desert assessment area, Greater Green River Basin, Wyoming. 


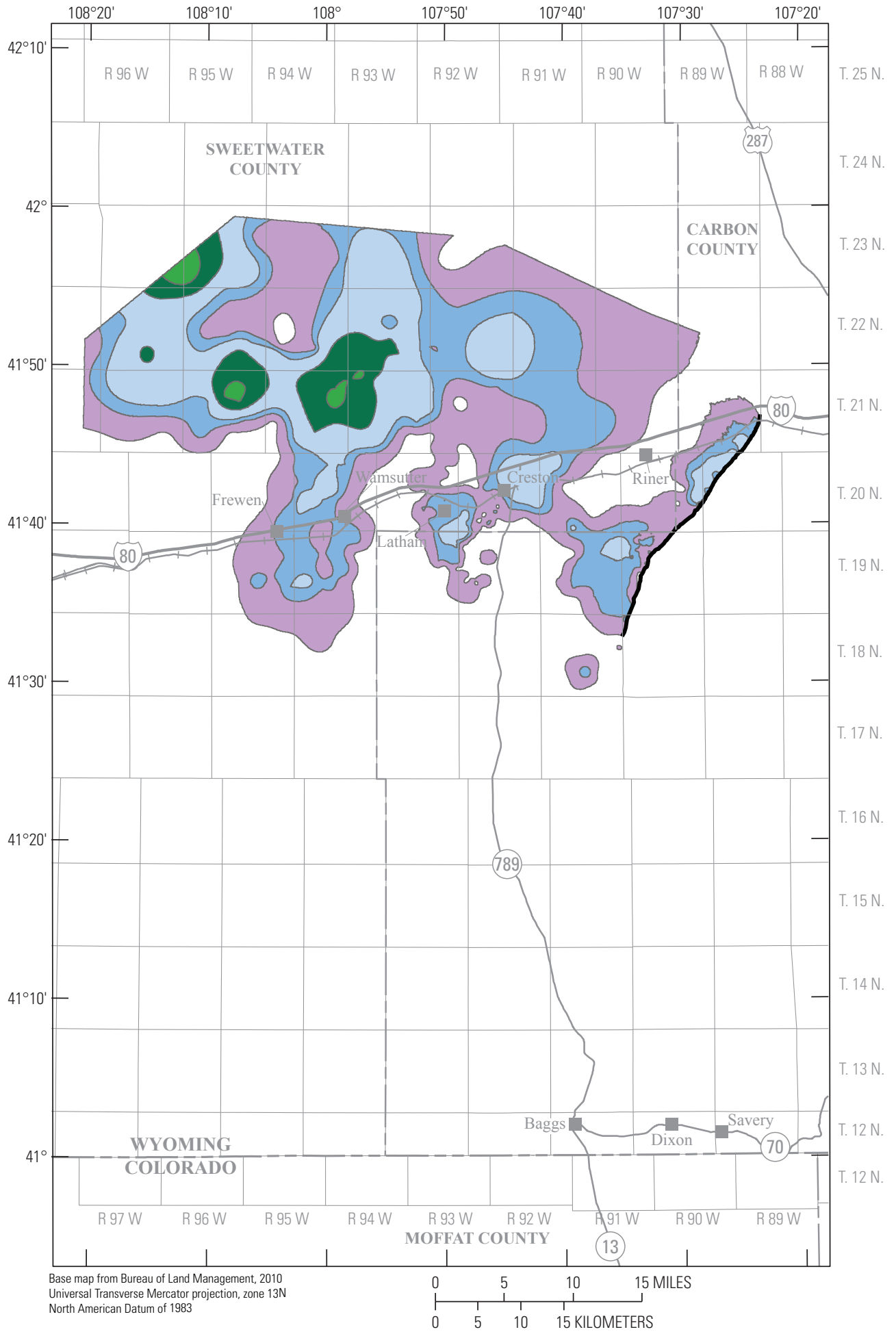

EXPLANATION

Daley Ranch coal bed isopach, in feet

15 to 20

10 to 15

5 to 10

3 to 5

0 to 3

Crop line

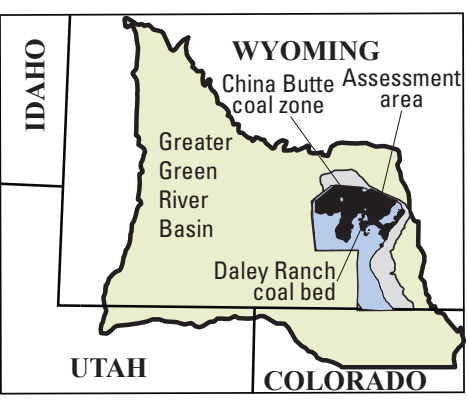

Figure 83. Daley Ranch coal bed showing extent of coal within the Little Snake River coal field and Red Desert assessment area, Greater Green River Basin, Wyoming. 


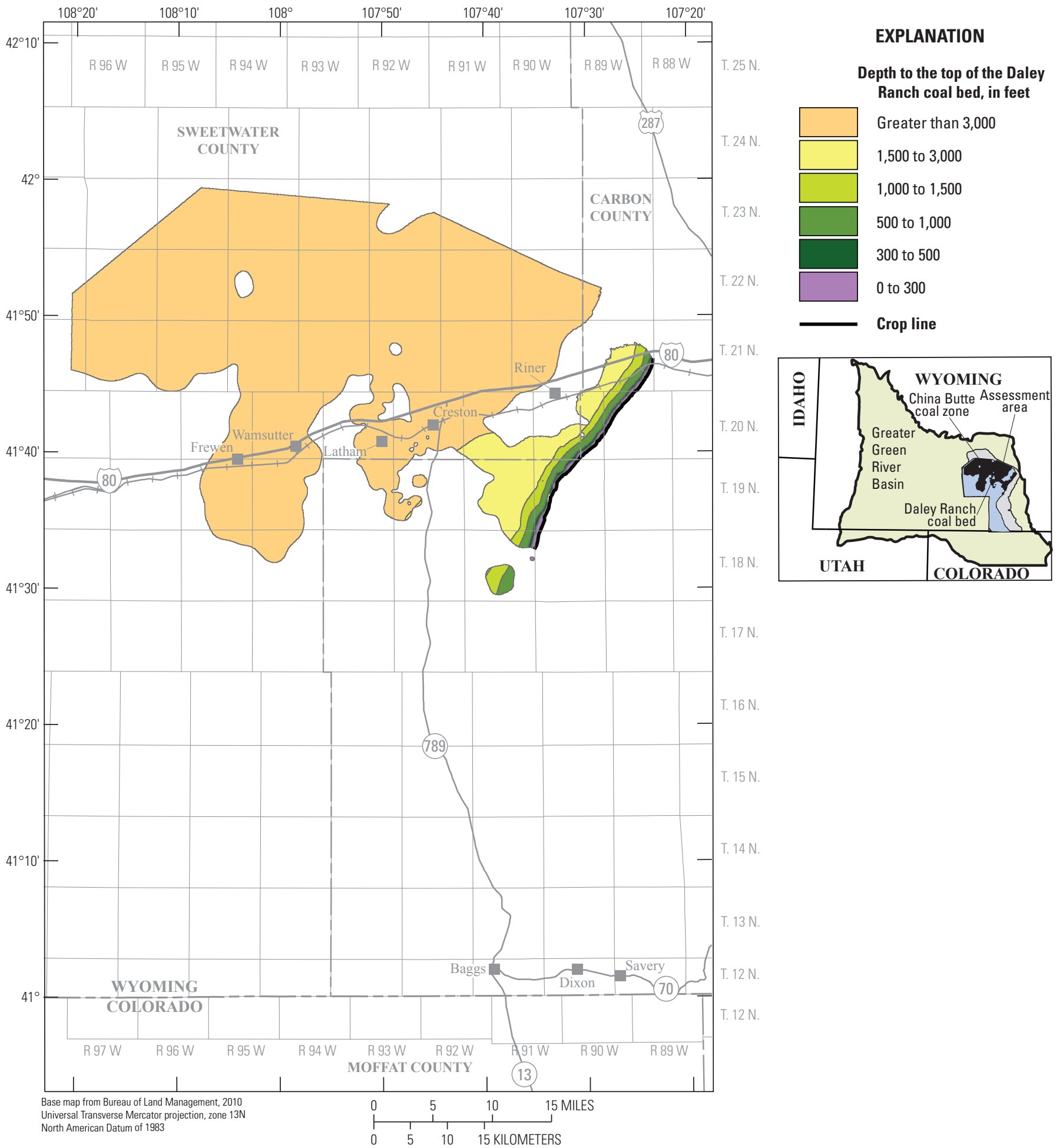

Figure 84. Depth to the top of the Daley Ranch coal bed within the Little Snake River coal field and Red Desert assessment area, Greater Green River Basin, Wyoming. 


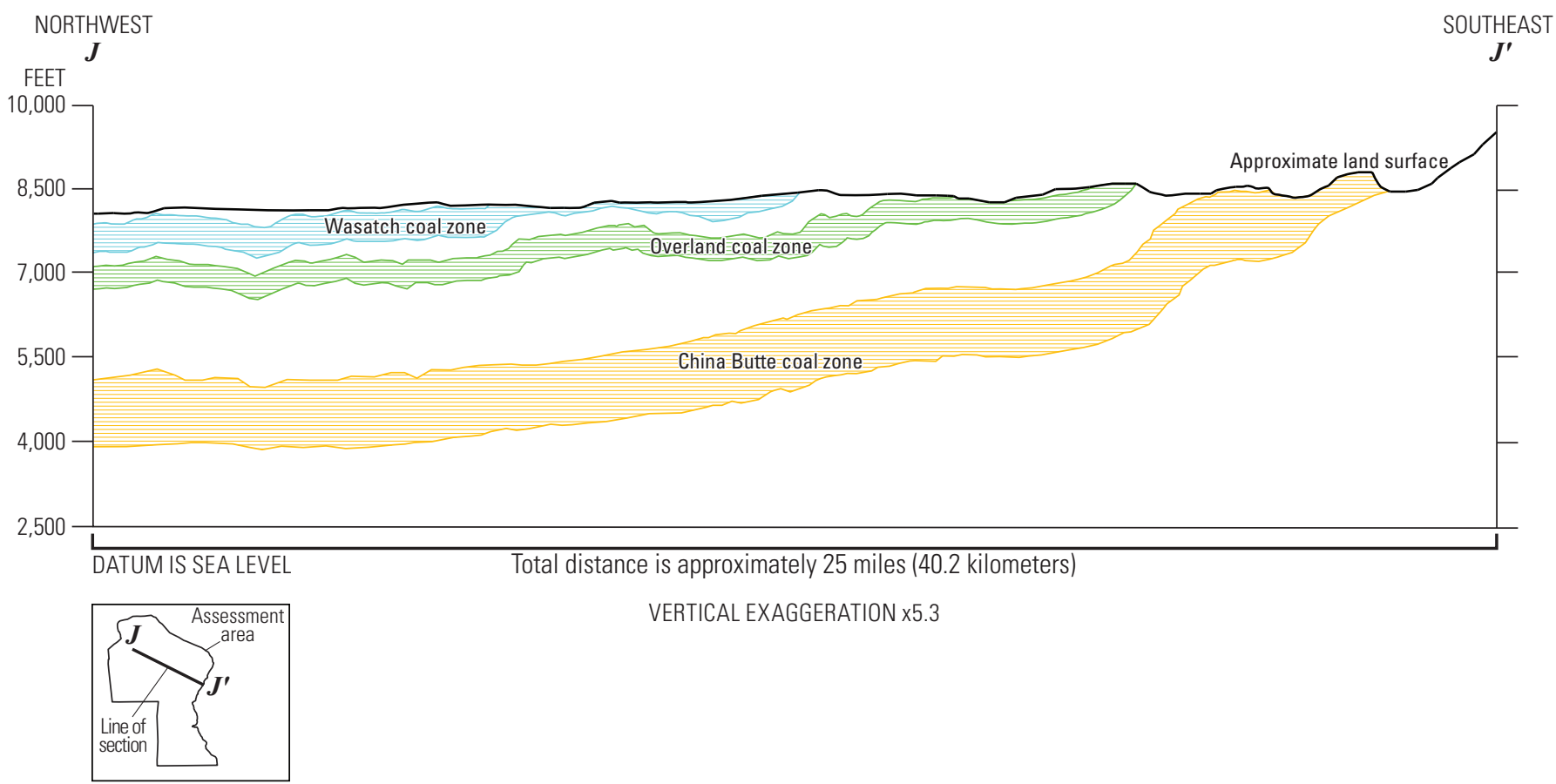

Figure 85. Northwest-southeast cross section $J-J$ 'showing approximate subsurface distribution of Paleogene coal zones in the Little Snake River coal field and Red Desert assessment area, Greater Green River Basin, Wyoming. 


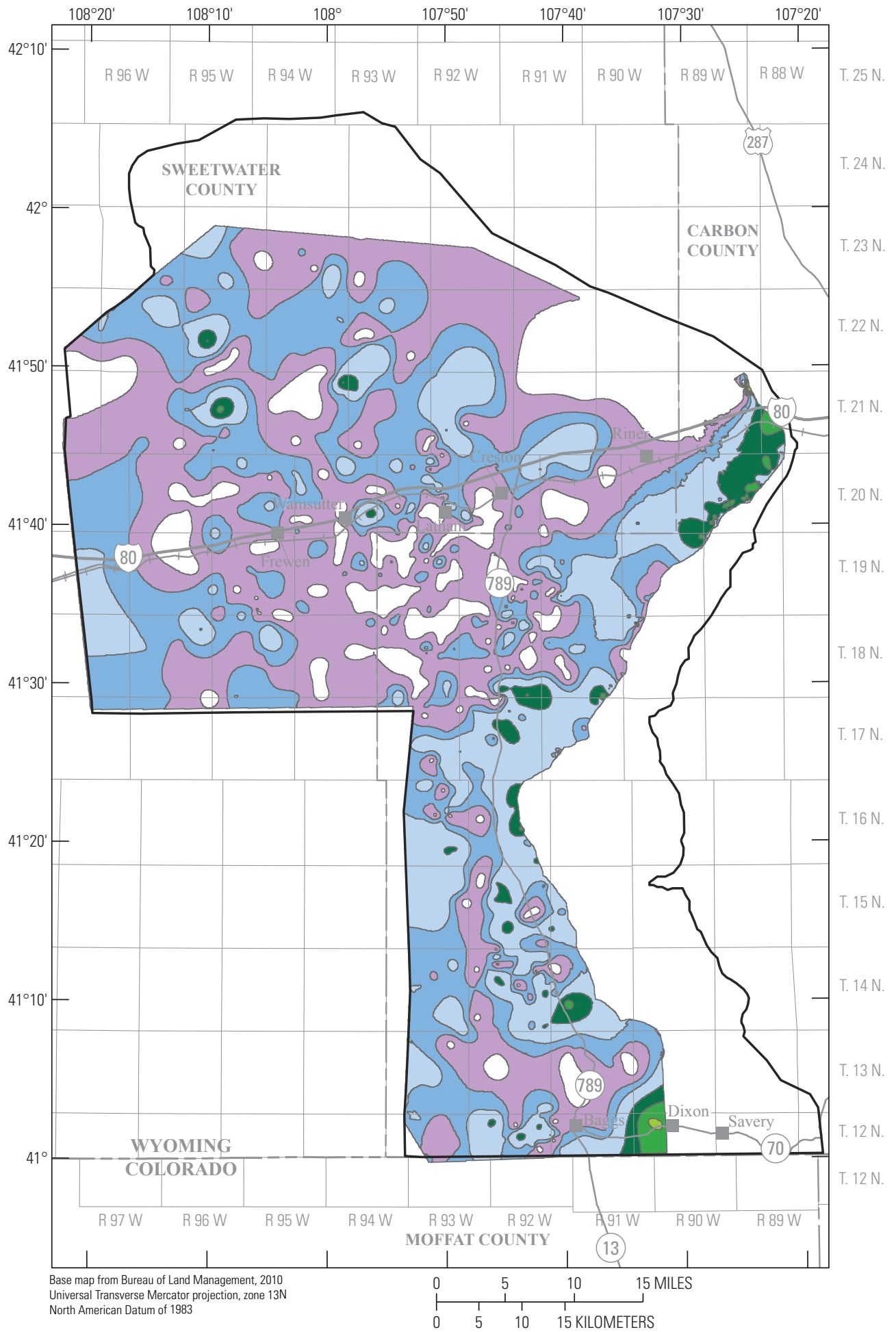

\section{EXPLANATION}

Lance coal zone total coal isopach, in feet

25 to 30

20 to 25

15 to 20

10 to 15

5 to 10

3 to 5

0 to 3

Little Snake River coal field and Red Desert assessment area boundary

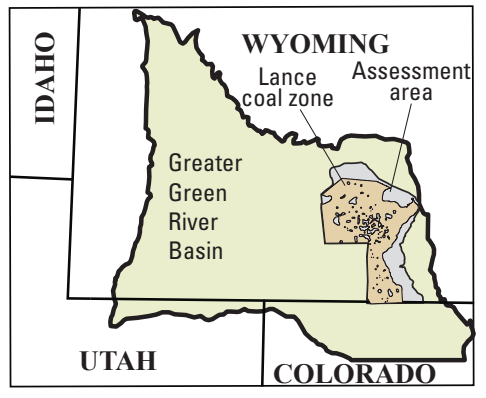

Figure 86. Composite thickness of all coal beds in the Lance coal zone within the Little Snake River coal field and Red Desert assessment area, Greater Green River Basin, Wyoming. 


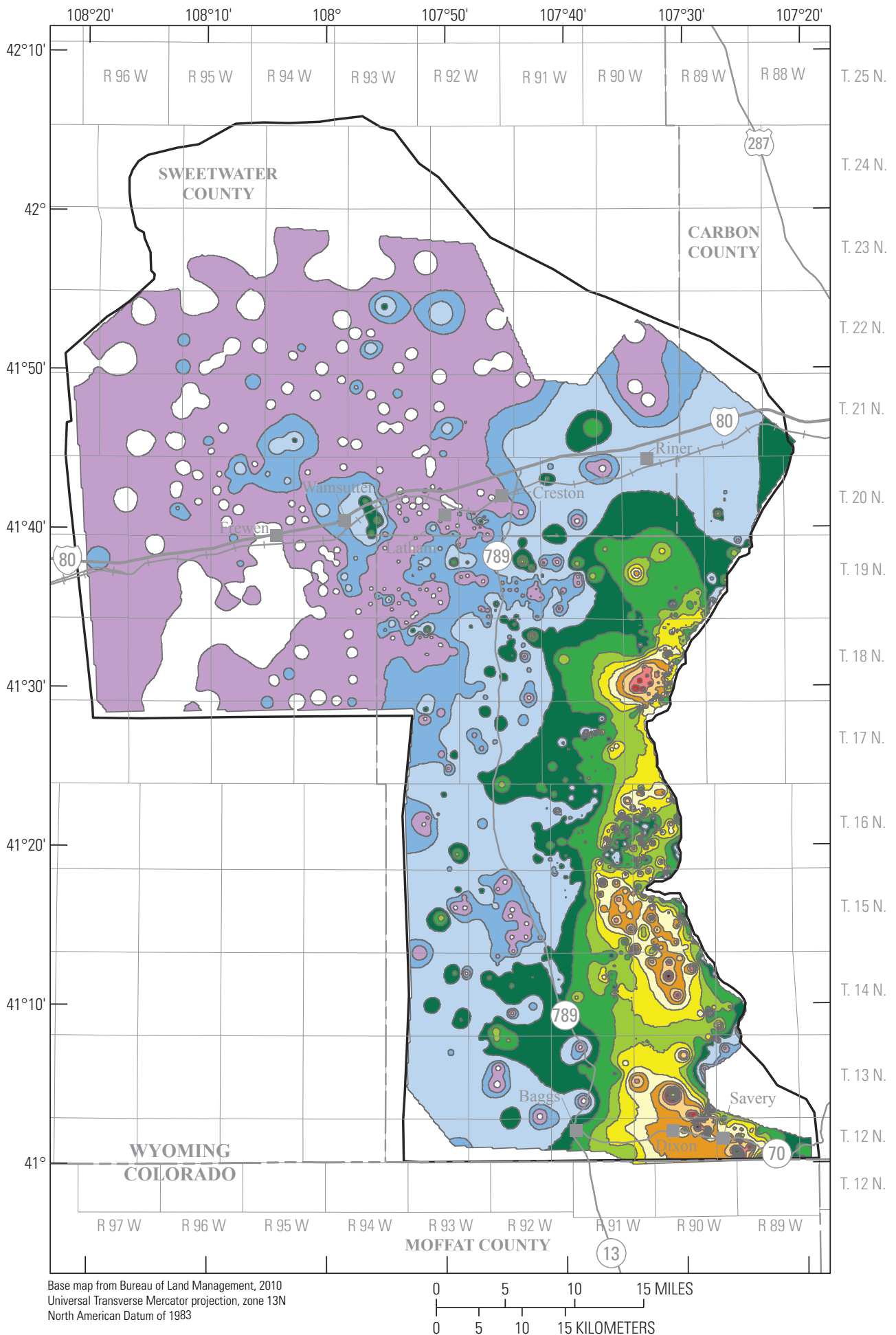

\section{EXPLANATION}

Almond coal zone total coal isopach, in feet

Greater than 80

75 to 80

70 to 75

65 to 70

60 to 65

55 to 60

50 to 55

45 to 50

40 to 45

35 to 40

30 to 35

25 to 30

20 to 25

15 to 20

10 to 15

5 to 10

3 to 5

0 to 3

Little Snake River coal field and Red Desert assessment area boundary

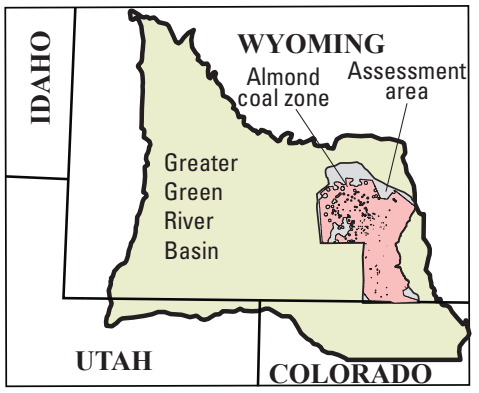

Figure 87. Composite thickness of all coal beds in the Almond coal zone within the Little Snake River coal field and Red Desert assessment area, Greater Green River Basin, Wyoming. 


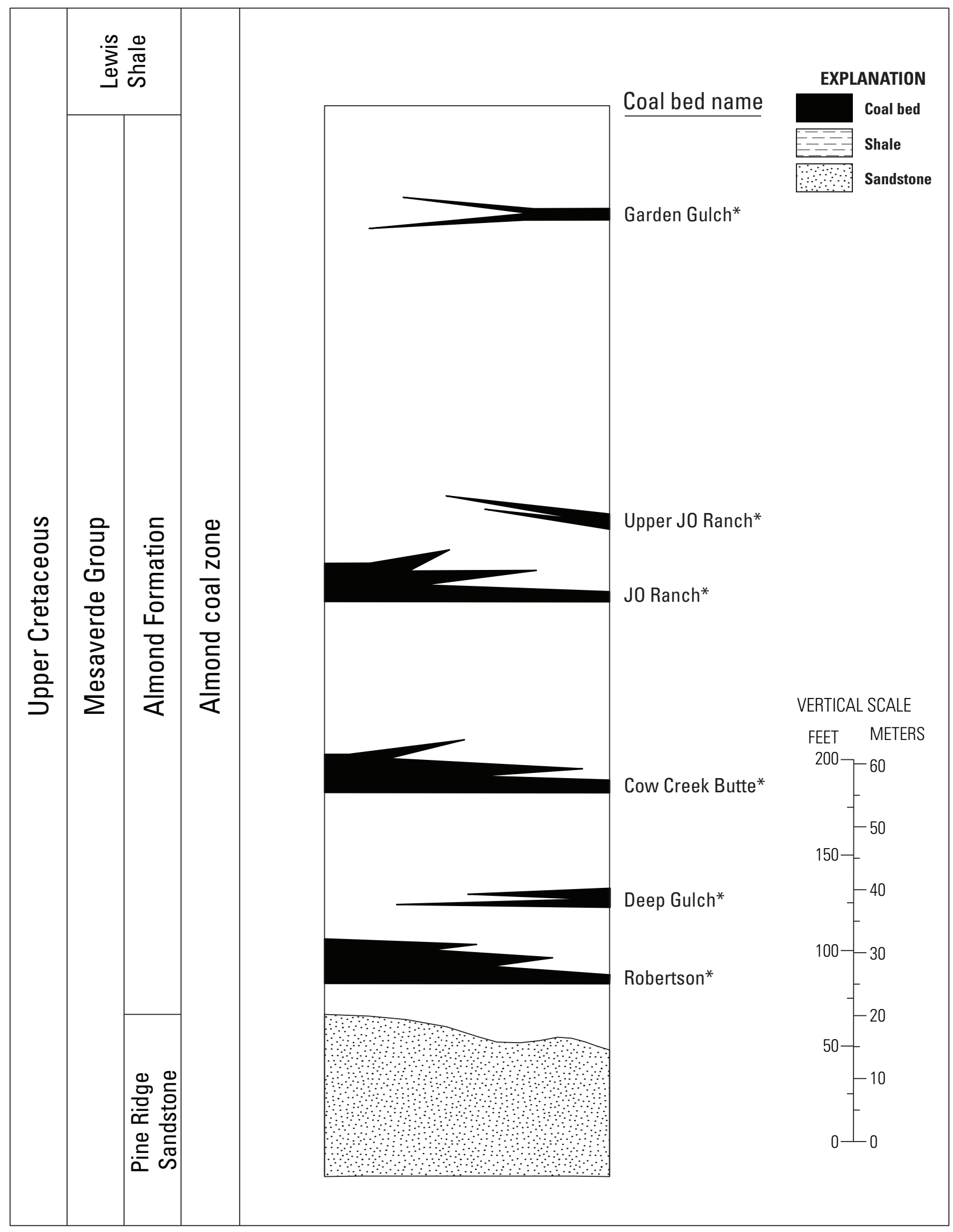

Figure 88. Generalized stratigraphic column showing coal beds in the Almond Formation coal zone in the Little Snake River coal field and Red Desert assessment area, Greater Green River Basin, Wyoming. Asterisk indicates that resources were calculated for bed. 


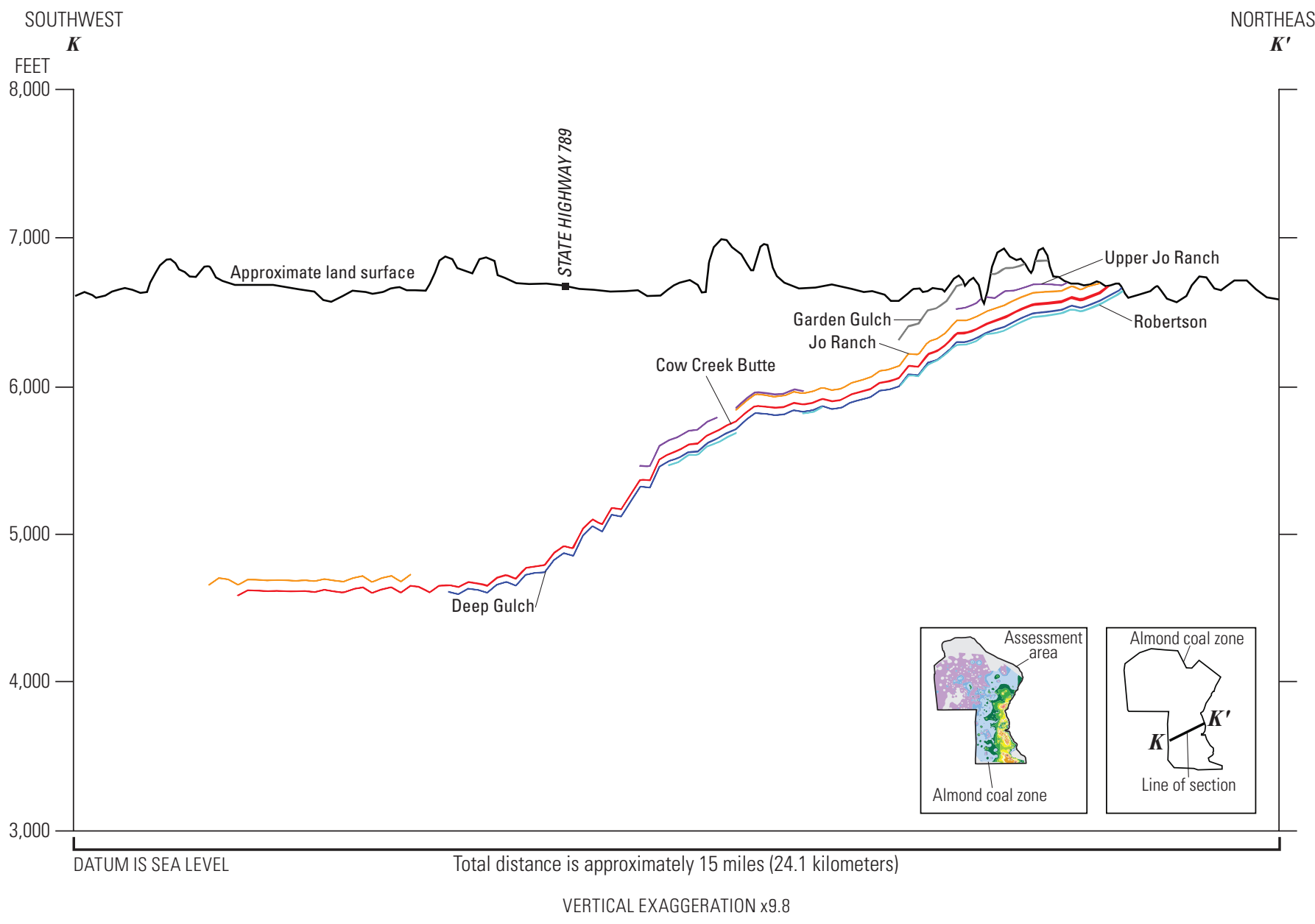

Figure 89. Southwest-northeast cross section $K-K^{\prime}$ showing approximate subsurface distribution of coal beds in the Almond Formation in the Little Snake River coal field and Red Desert assessment area, Greater Green River Basin, Wyoming. 


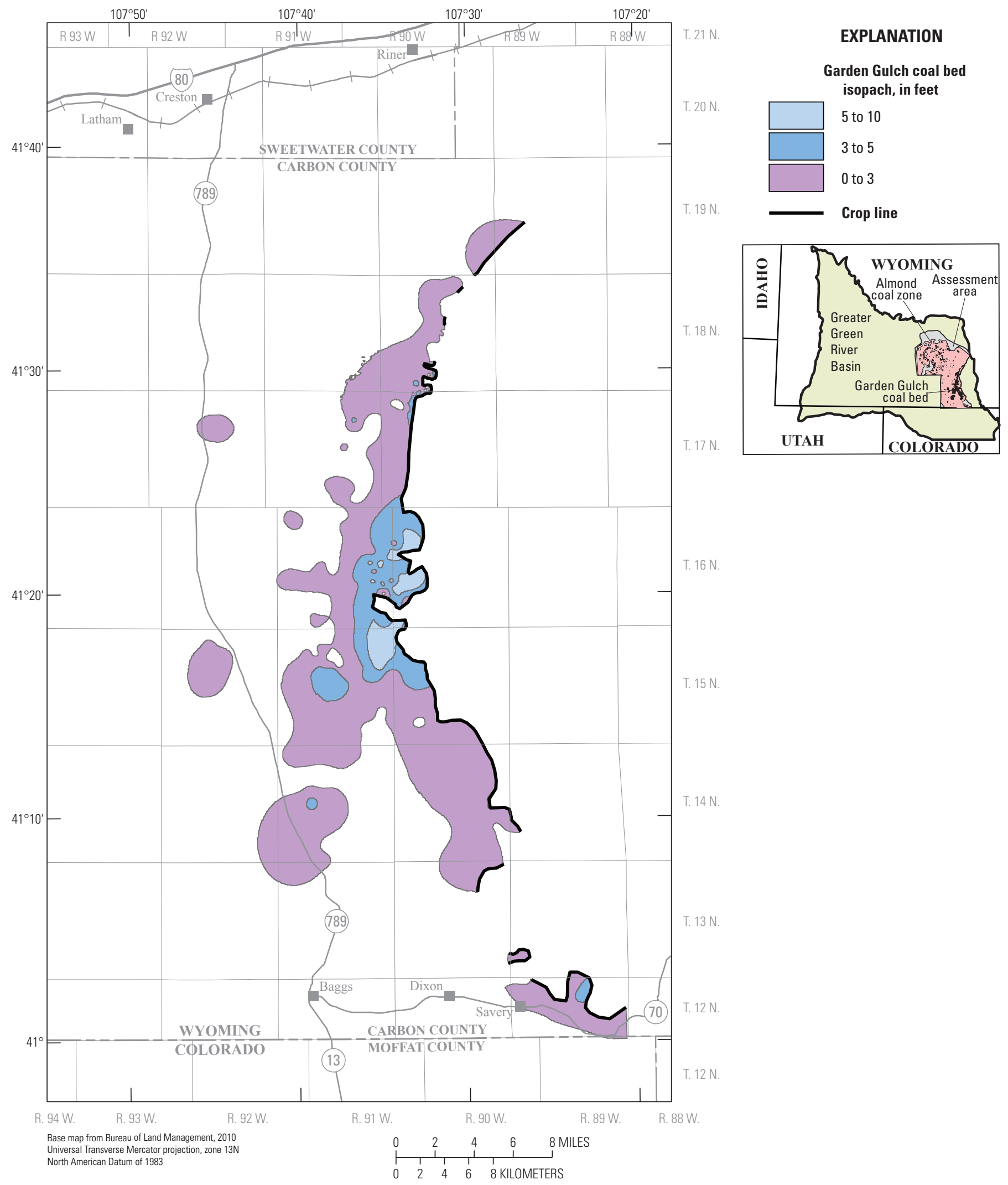

Figure 90. Garden Gulch coal bed showing extent of coal within the Little Snake River coal field and Red Desert assessment area, Greater Green River Basin, Wyoming. 


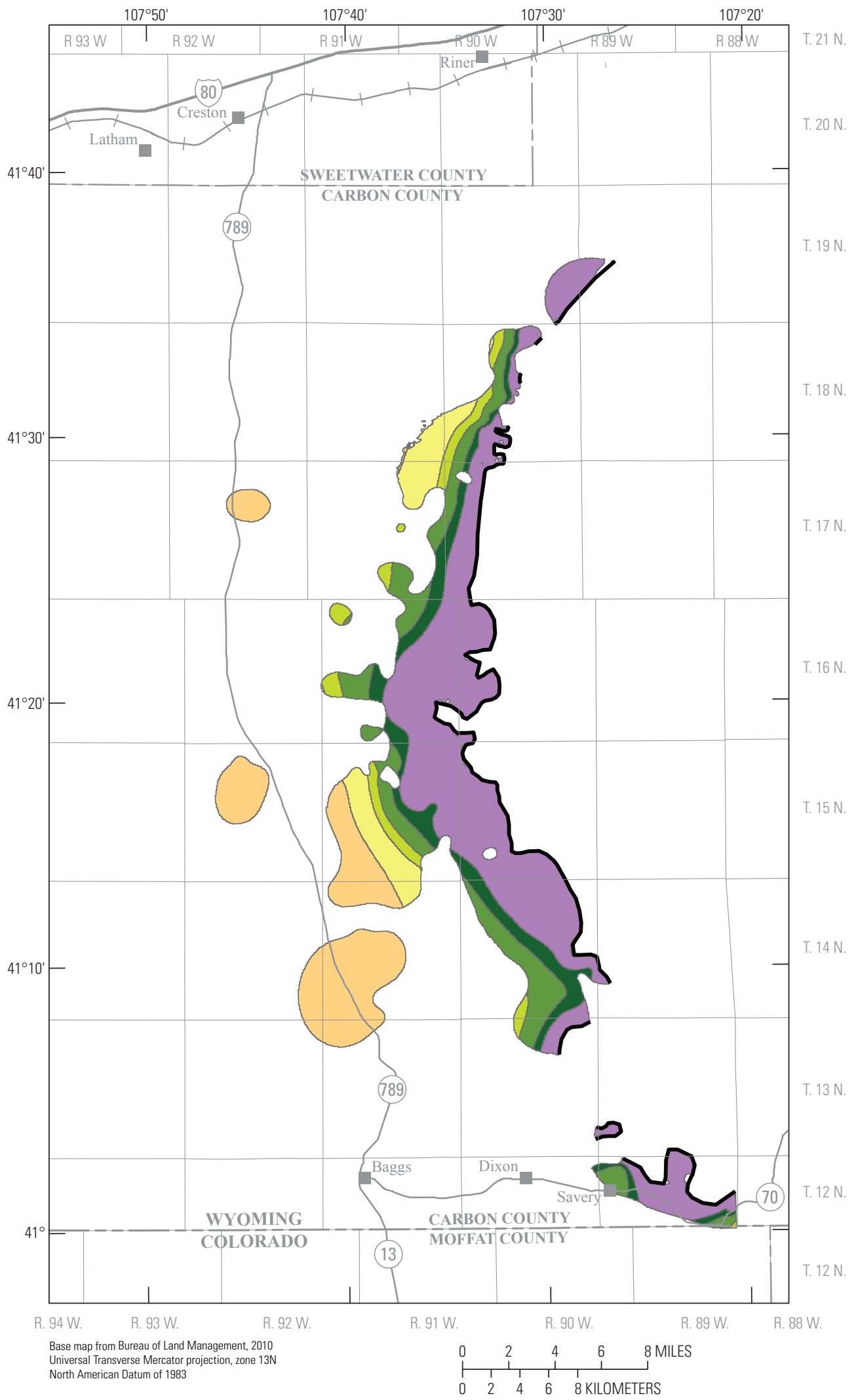

EXPLANATION

Depth to the top of the Garden Gulch coal bed, in feet

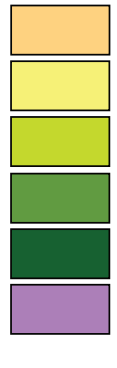

Greater than 3,000

1,500 to 3,000

1,000 to 1,500

500 to 1,000

300 to 500

0 to 300

Crop line

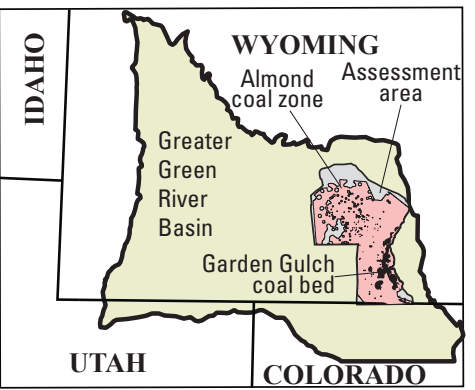

Figure 91. Depth to the top of the Garden Gulch coal bed within the Little Snake River coal field and Red Desert assessment area, Greater Green River Basin, Wyoming. 


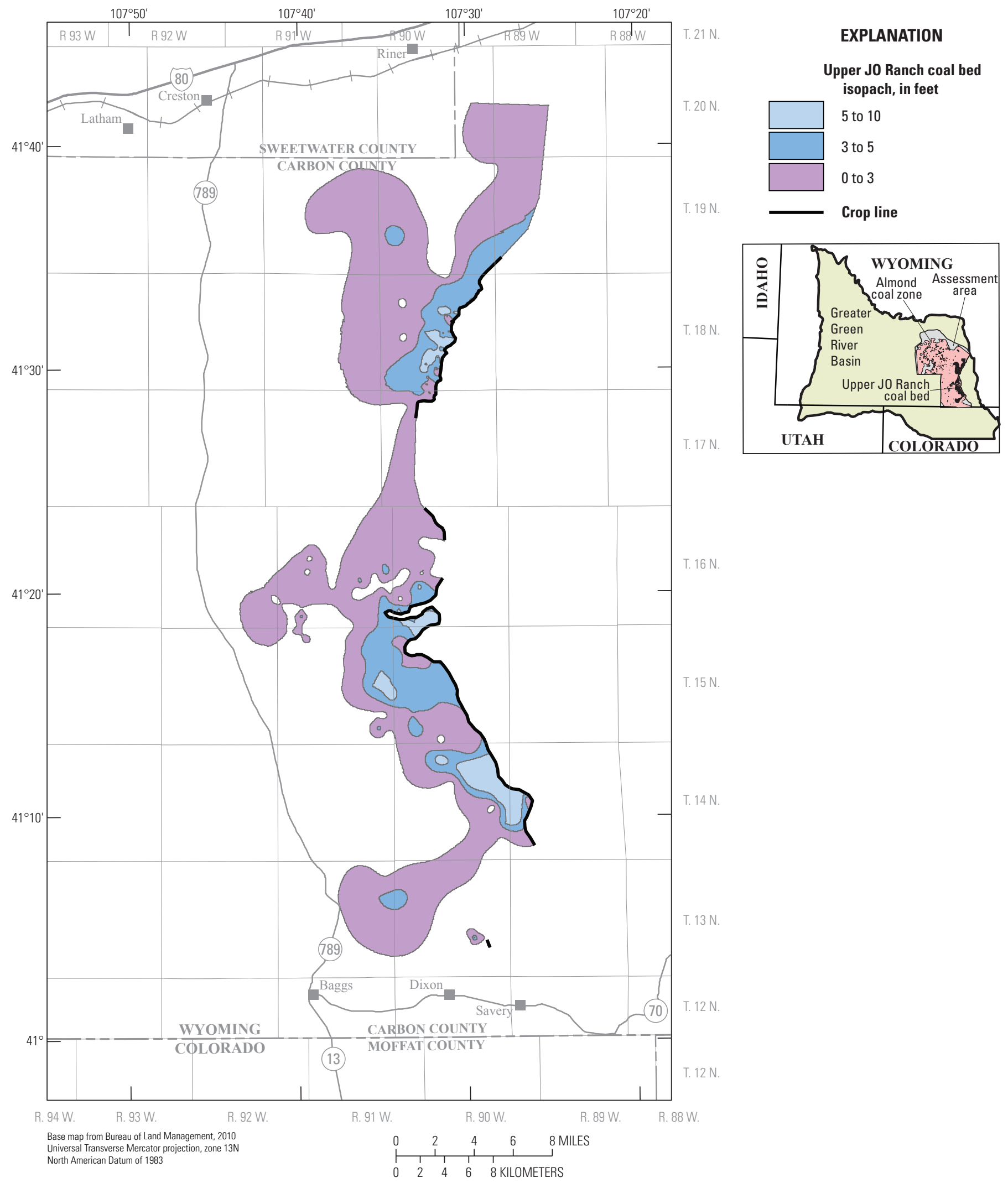

Figure 92. Upper JO Ranch coal bed showing extent of coal within the Little Snake River coal field and Red Desert assessment area, Greater Green River Basin, Wyoming. 


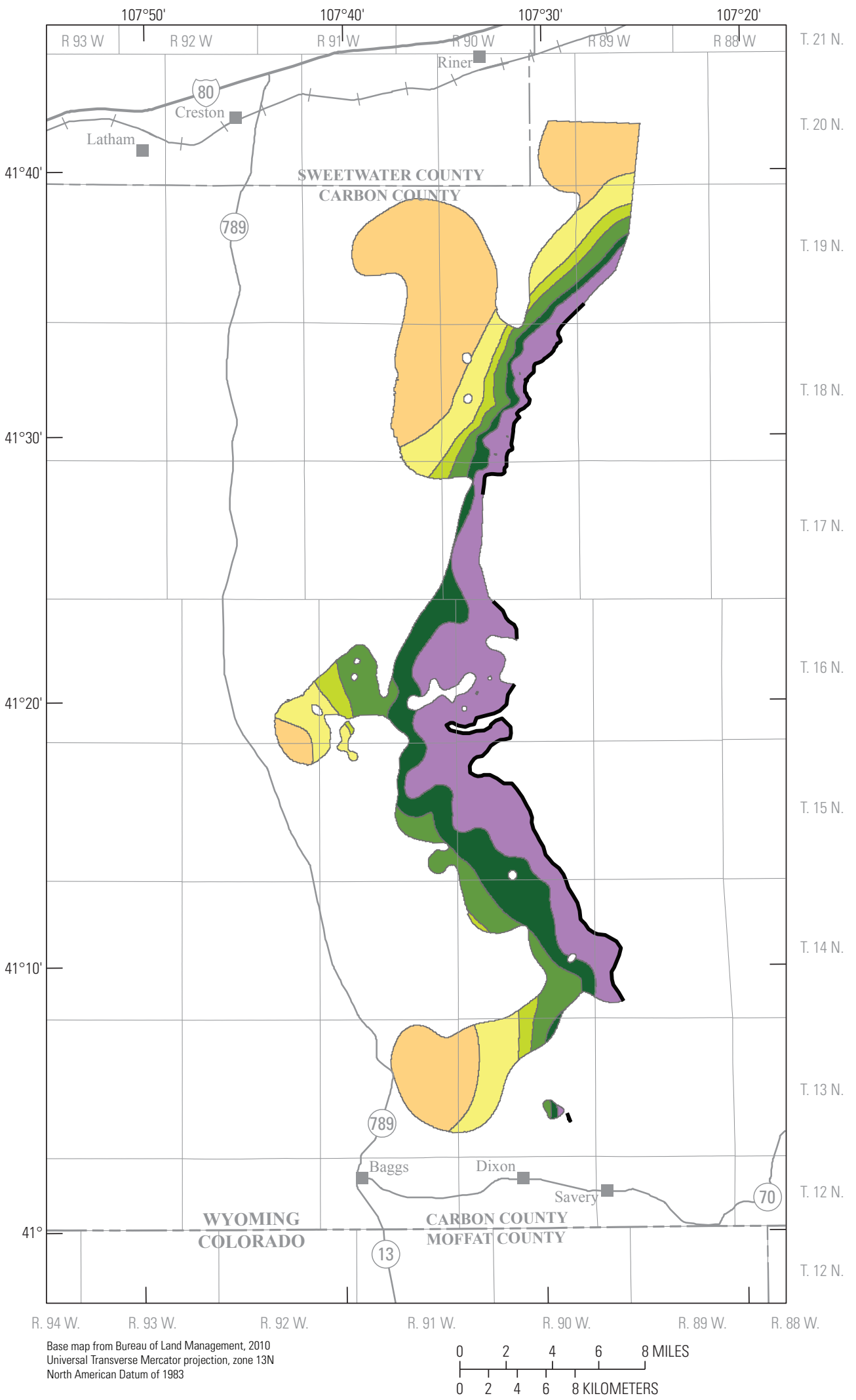

EXPLANATION

Depth to the top of the Upper JO Ranch coal bed, in feet

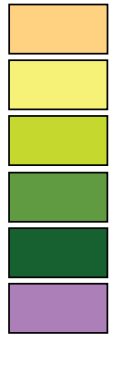

Greater than 3,000

1,500 to 3,000

1,000 to 1,500

500 to 1,000

300 to 500

0 to 300

Crop line

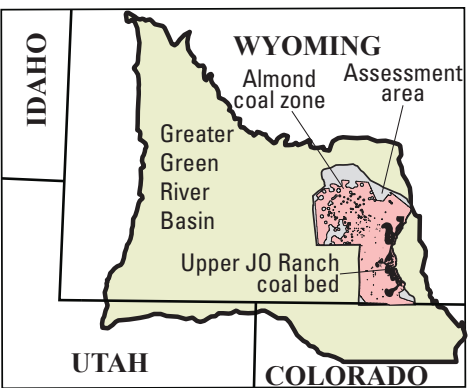

Figure 93. Depth to the top of the Upper J0 Ranch coal bed within the Little Snake River coal field and Red Desert assessment area, Greater Green River Basin, Wyoming. 


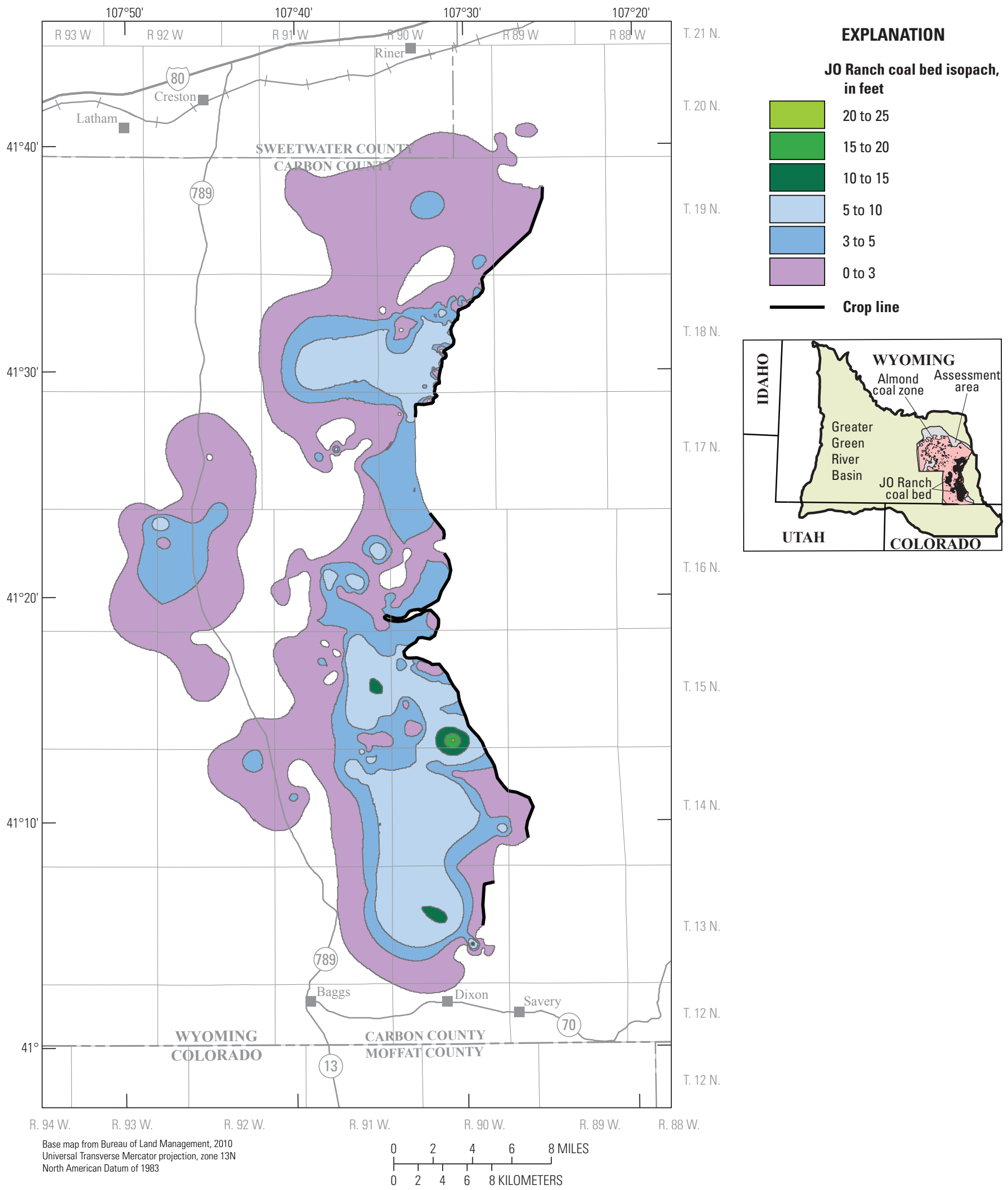

Figure 94. JO Ranch coal bed showing extent of coal within the Little Snake River coal field and Red Desert assessment area, Greater Green River Basin, Wyoming. 


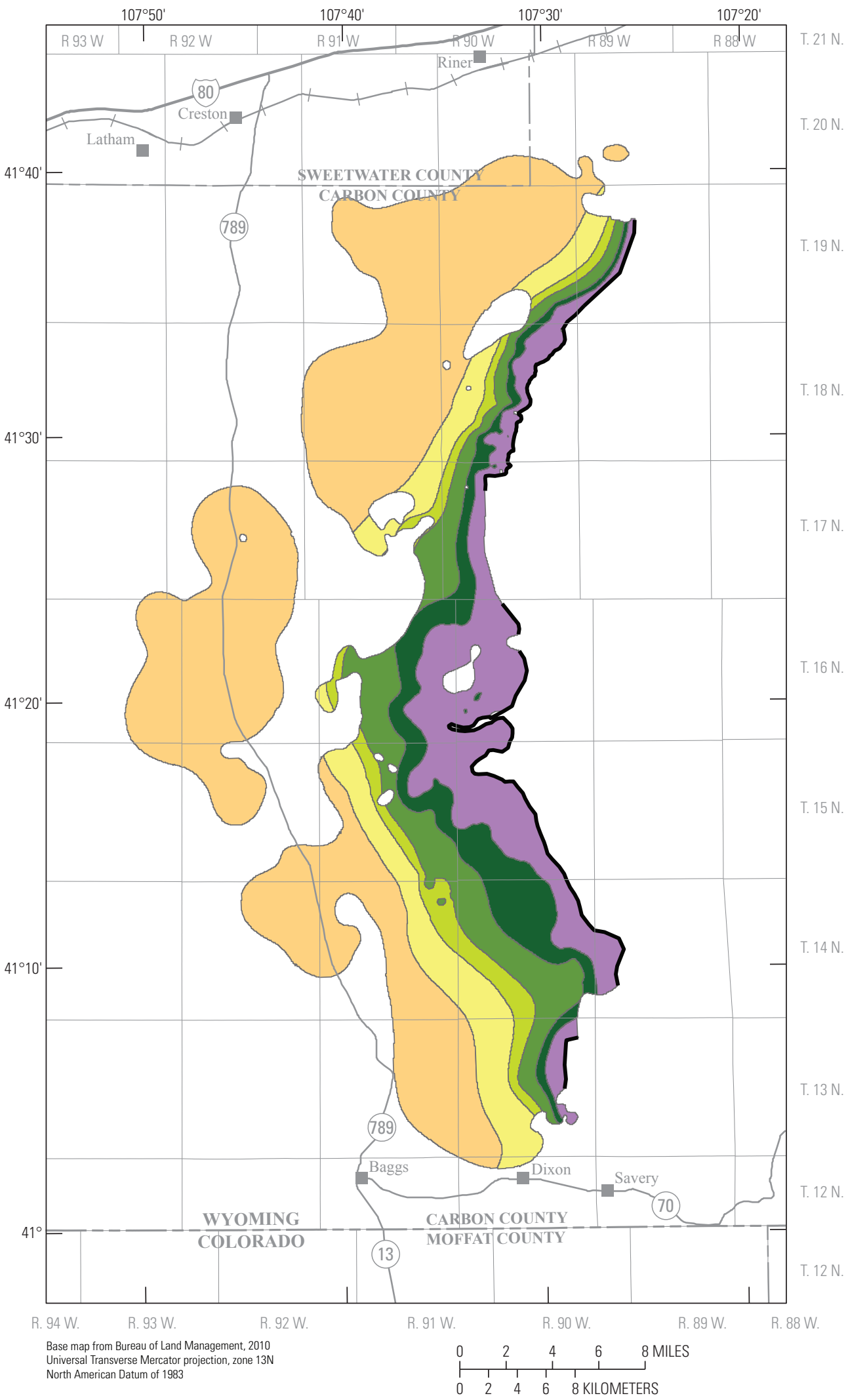

EXPLANATION

Depth to the top of the JO Ranch coal bed, in feet

\begin{tabular}{|l|l}
\hline & Greater than 3,000 \\
\hline \hline & 1,500 to 3,000
\end{tabular}

1,500 to 3,000

1,000 to 1,500

500 to 1,000

300 to 500

0 to 300
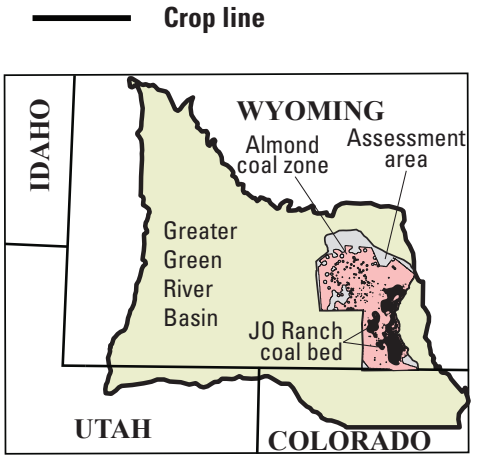

Figure 95. Depth to the top of the J0 Ranch coal bed within the Little Snake River coal field and Red Desert assessment area, Greater Green River Basin, Wyoming. 


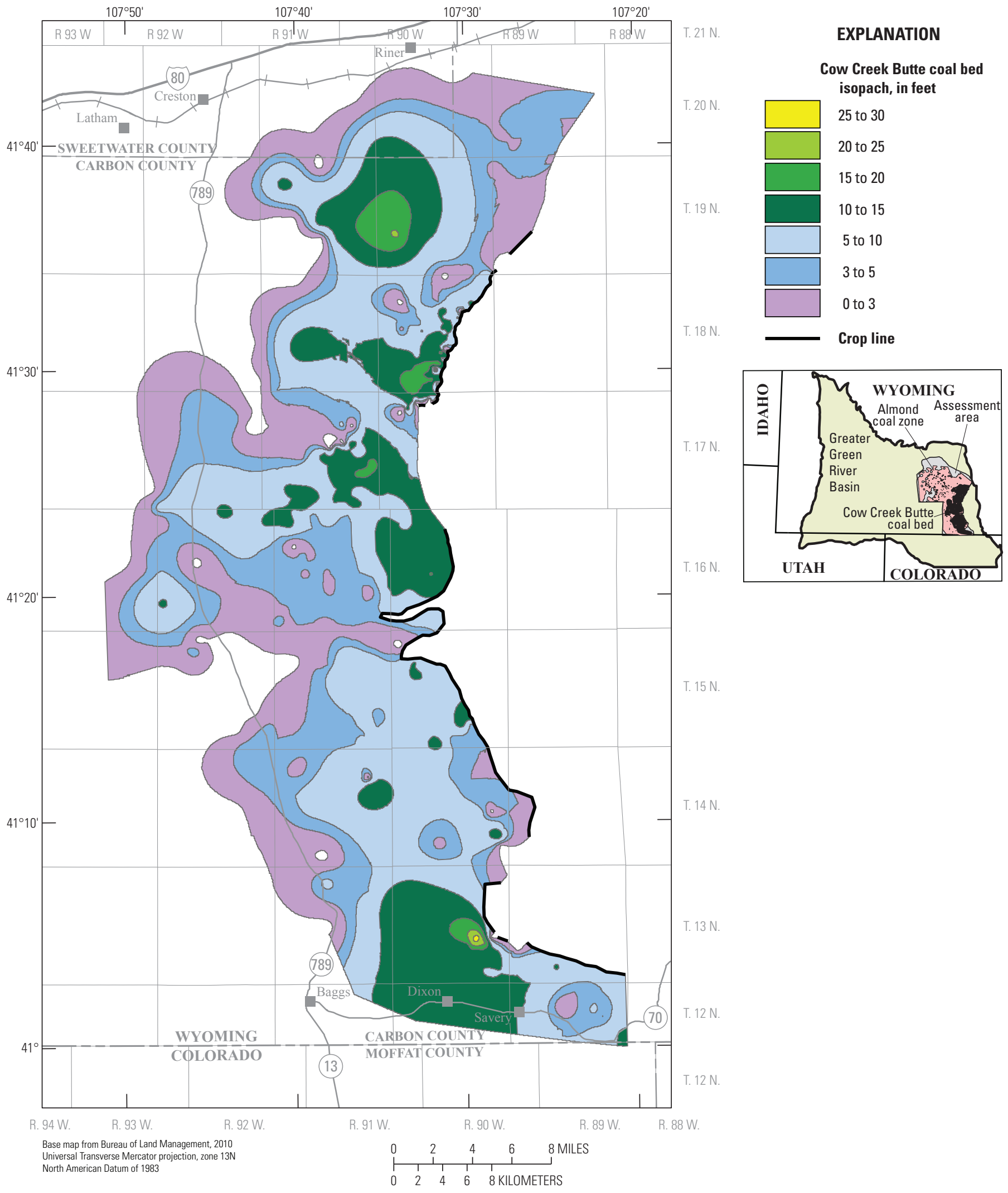

Figure 96. Cow Creek Butte coal bed showing extent of coal within the Little Snake River coal field and Red Desert assessment area, Greater Green River Basin, Wyoming. 


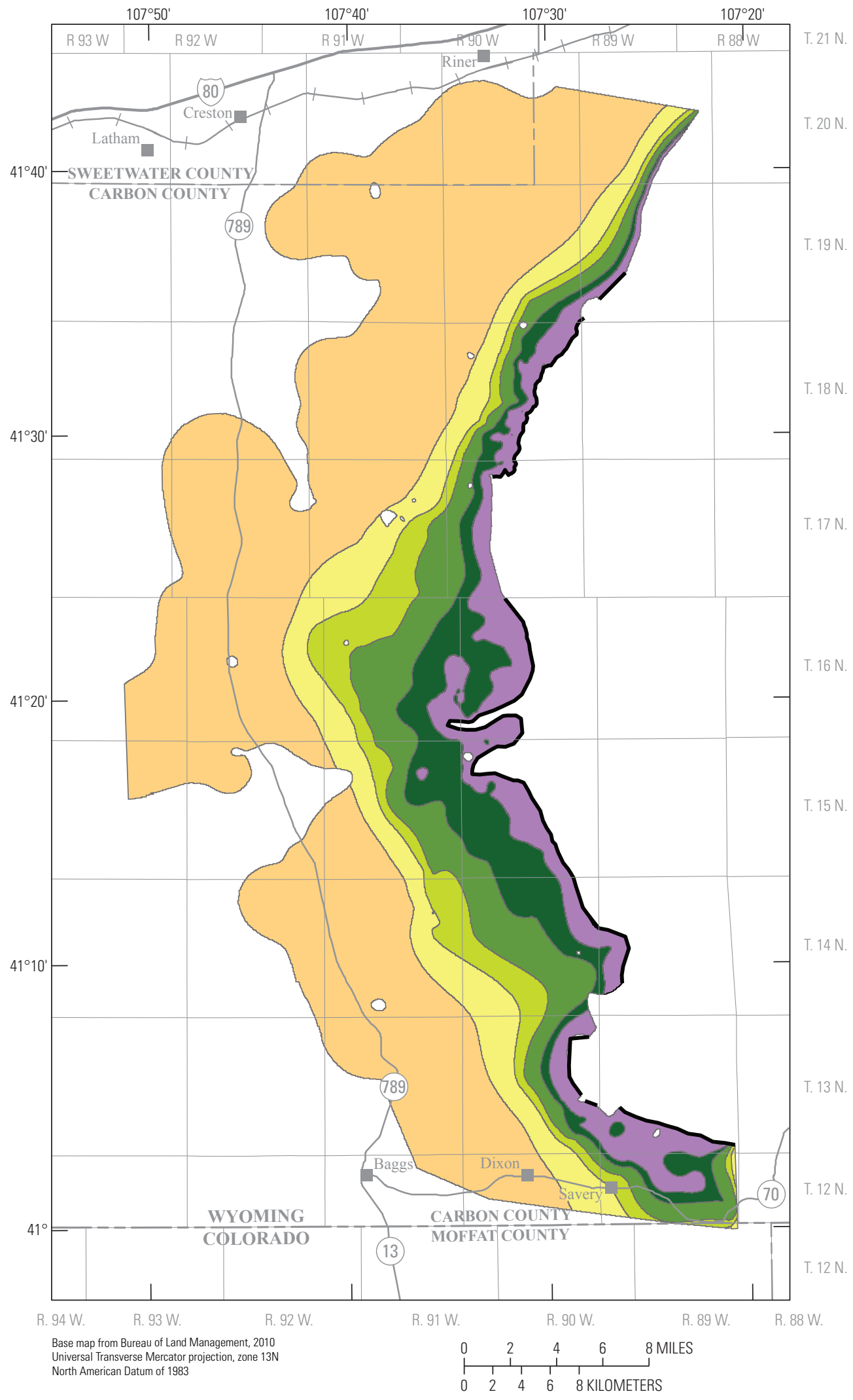

\section{EXPLANATION}

Depth to the top of the Cow Creek Butte coal bed, in feet

\begin{tabular}{|l|l}
\hline Greater than 3,000 \\
\hline \hline 1,500 to 3,000
\end{tabular}

1,500 to 3,000

1,000 to 1,500

500 to 1,000

300 to 500

0 to 300

Crop line

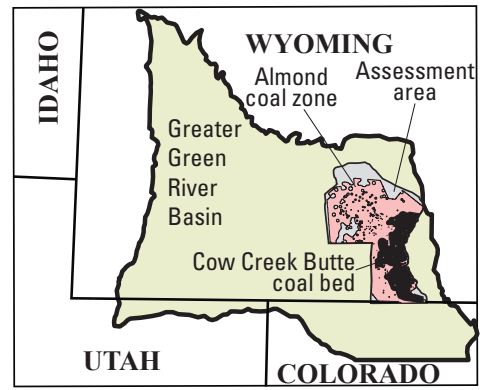

Figure 97. Depth to the top of the Cow Creek Butte coal bed within the Little Snake River coal field and Red Desert assessment area, Greater Green River Basin, Wyoming. 


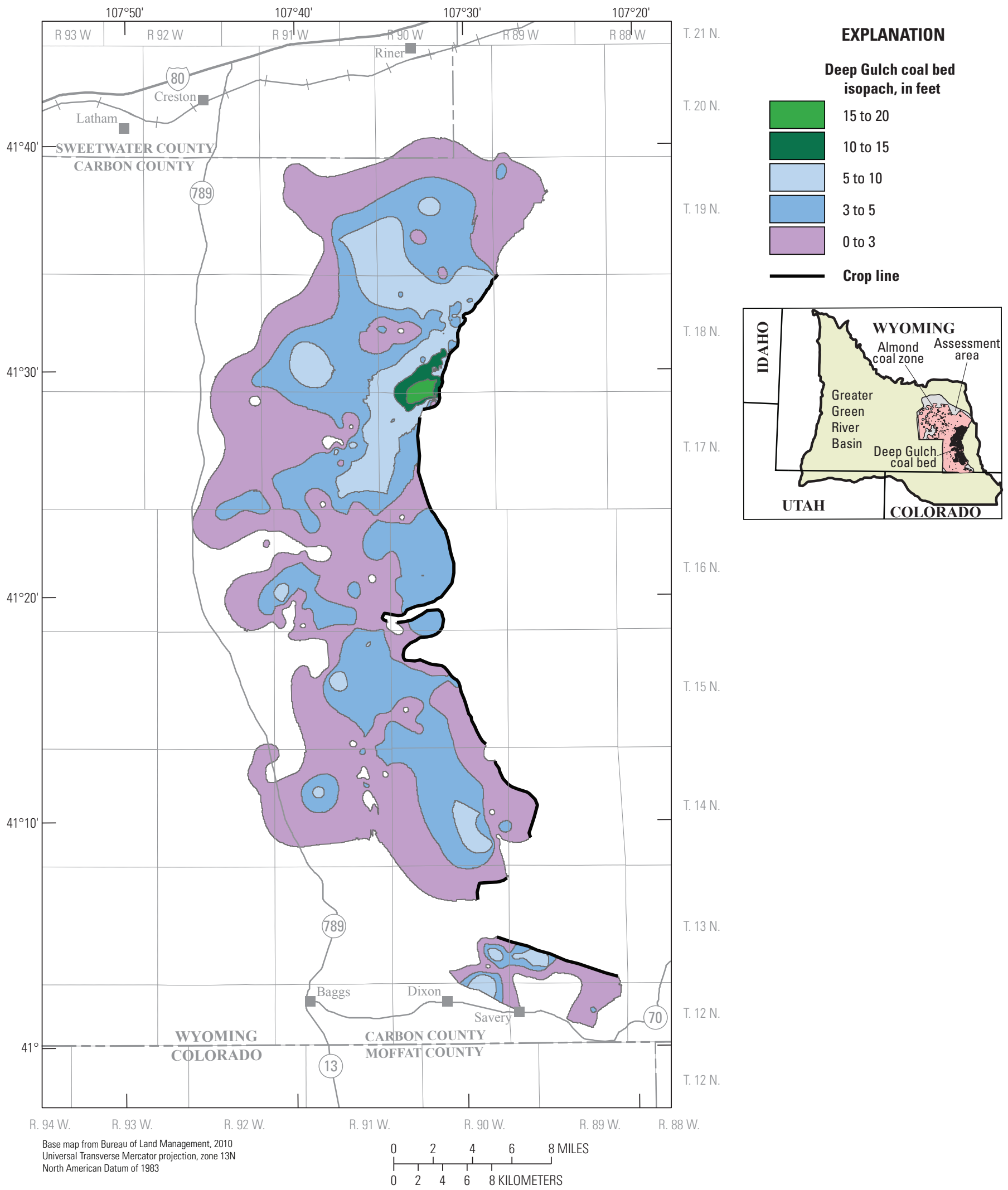

Figure 98. Deep Gulch coal bed showing extent of coal within the Little Snake River coal field and Red Desert assessment area, Greater Green River Basin, Wyoming. 


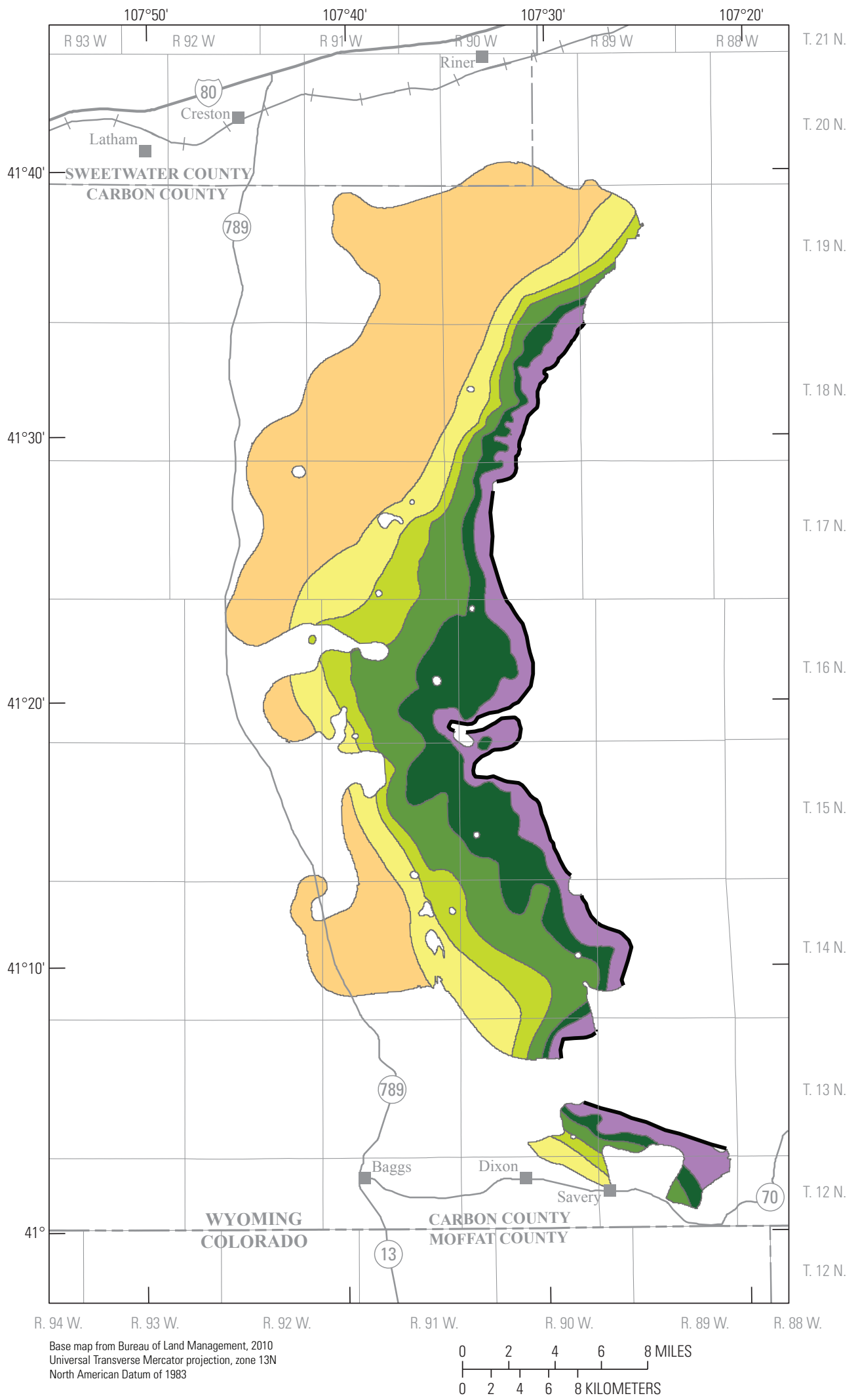

EXPLANATION

Depth to the top of the Deep Gulch coal bed, in feet

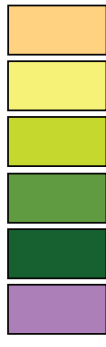

Greater than 3,000

1,500 to 3,000

1,000 to 1,500

500 to 1,000

300 to 500

0 to 300
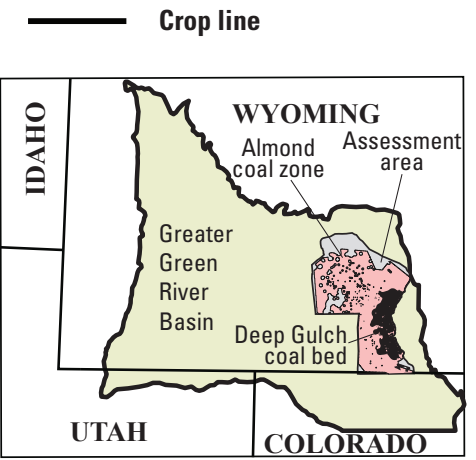

Figure 99. Depth to the top of the Deep Gulch coal bed within the Little Snake River coal field and Red Desert assessment area, Greater Green River Basin, Wyoming. 


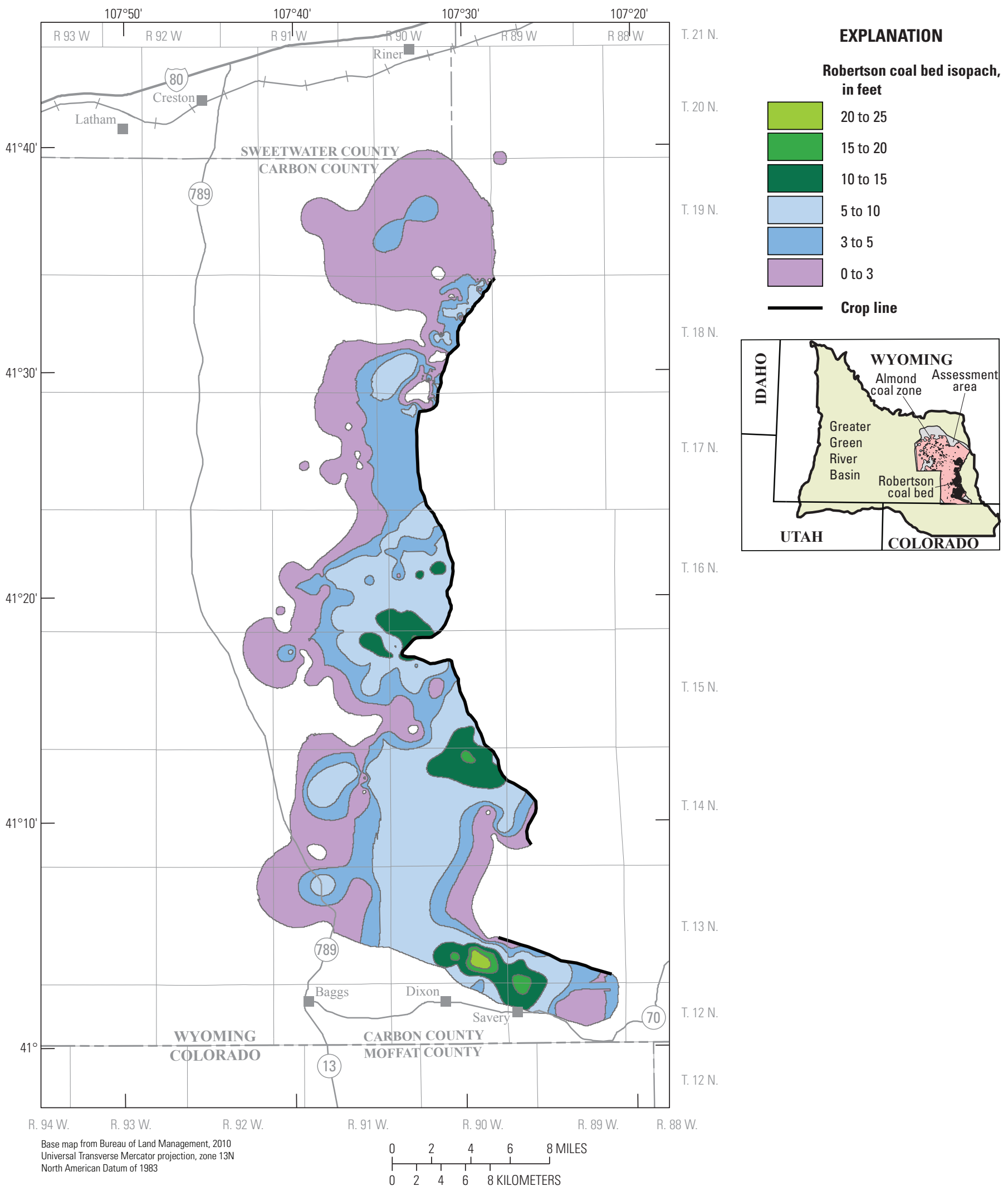

Figure 100. Robertson coal bed showing extent of coal within the Little Snake River coal field and Red Desert assessment area, Greater Green River Basin, Wyoming. 


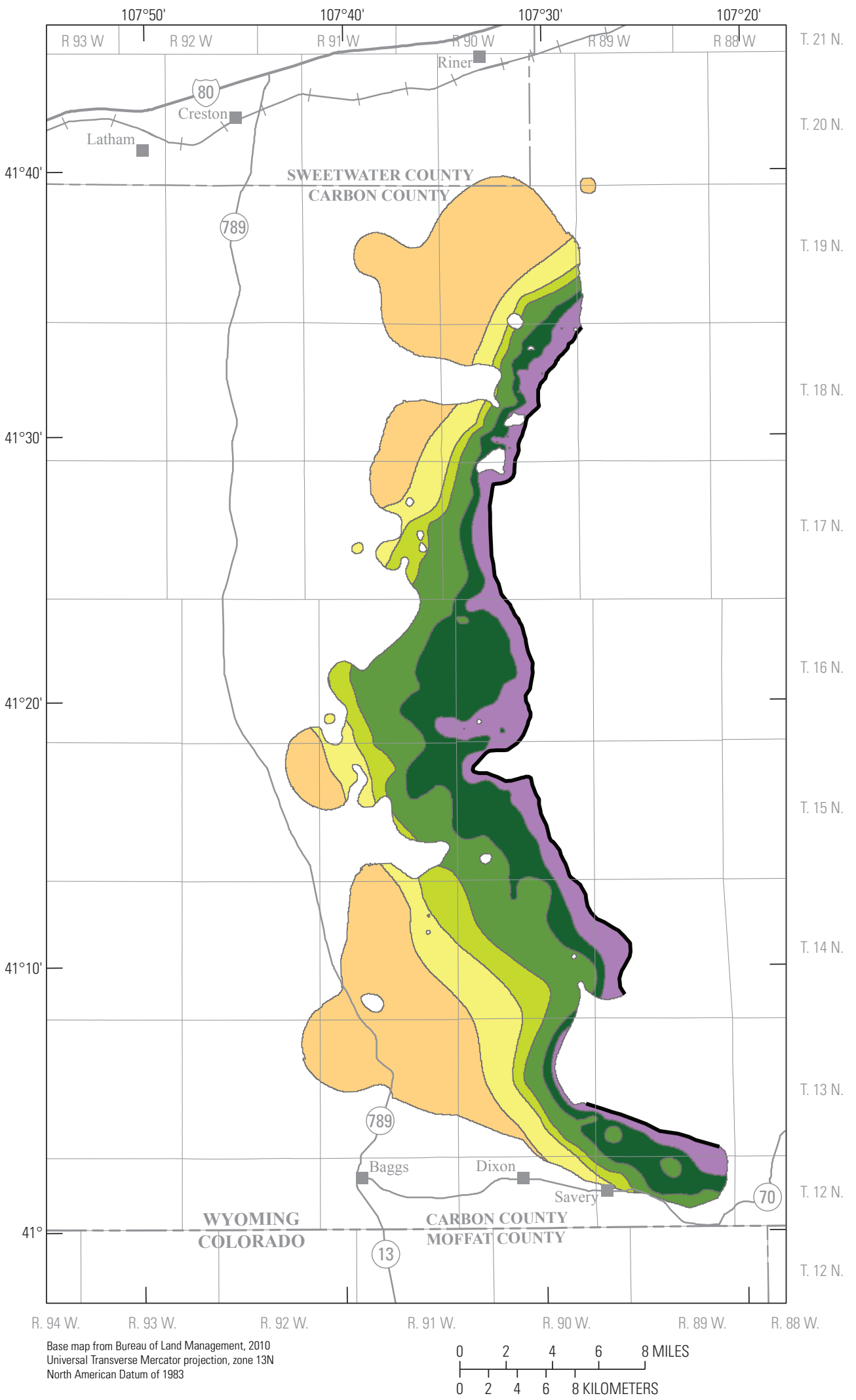

\section{EXPLANATION}

Depth to the top of the Robertson coal bed, in feet

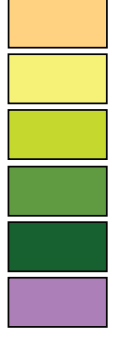

Greater than 3,000

1,500 to 3,000

1,000 to 1,500

500 to 1,000

300 to 500

0 to 300

\section{Crop line}

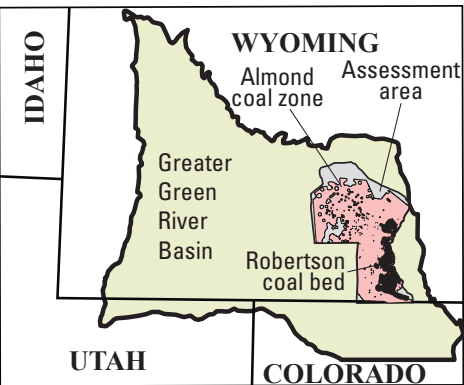

Figure 101. Depth to the top of the Robertson coal bed within the Little Snake River coal field and Red Desert assessment area, Greater Green River Basin, Wyoming. 


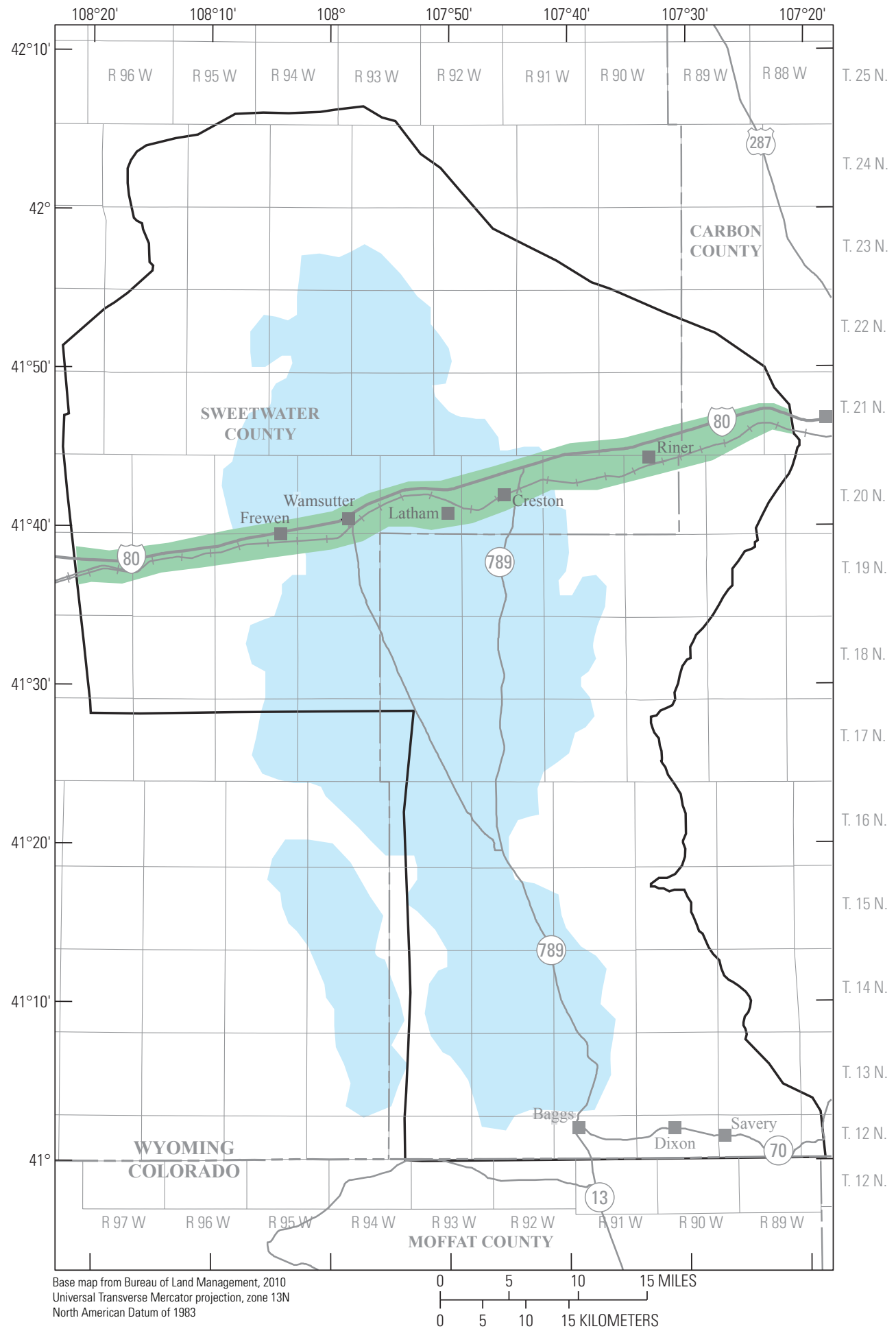

EXPLANATION

Approximate area of land-use restrictions due to Interstate $\mathbf{8 0}$ and the railroad

Approximate area of greater Wamsutter oil and gas fieldModified from Nelson and others (2009)

Little Snake River coal field and Red Desert assessment area boundary

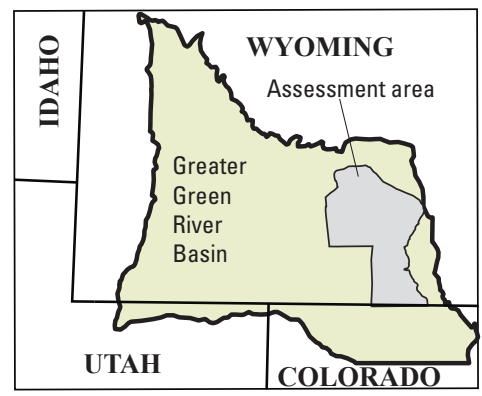

Figure 102. Approximate locations of the greater Wamsutter oil and gas field and land-use restrictions for U.S. Interstate 80 and the Burlington Northern Santa Fe railroad in the Little Snake River coal field and Red Desert assessment area, Greater Green River Basin, Wyoming. Modified from Nelson and others (2010). 


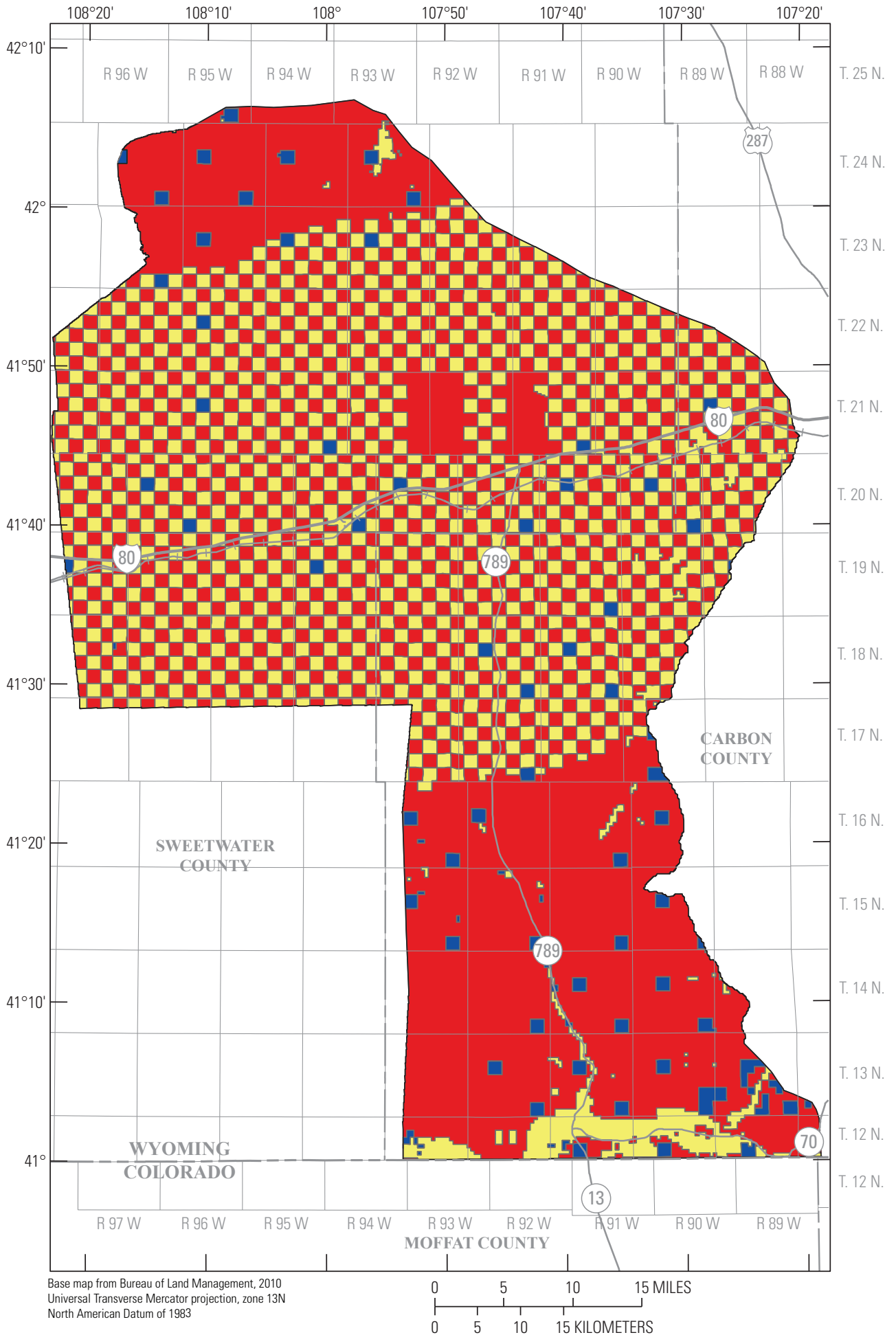

EXPLANATION
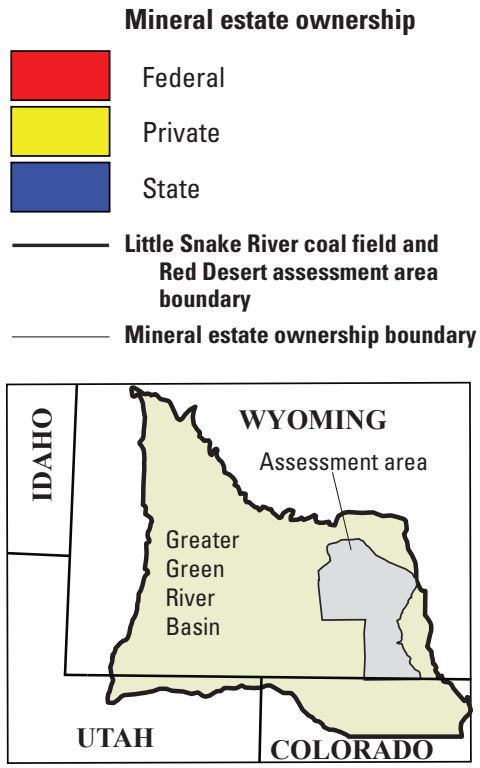

Figure 103. Mineral estate ownership in the Little Snake River coal field and Red Desert assessment area, Greater Green River Basin, Wyoming. 


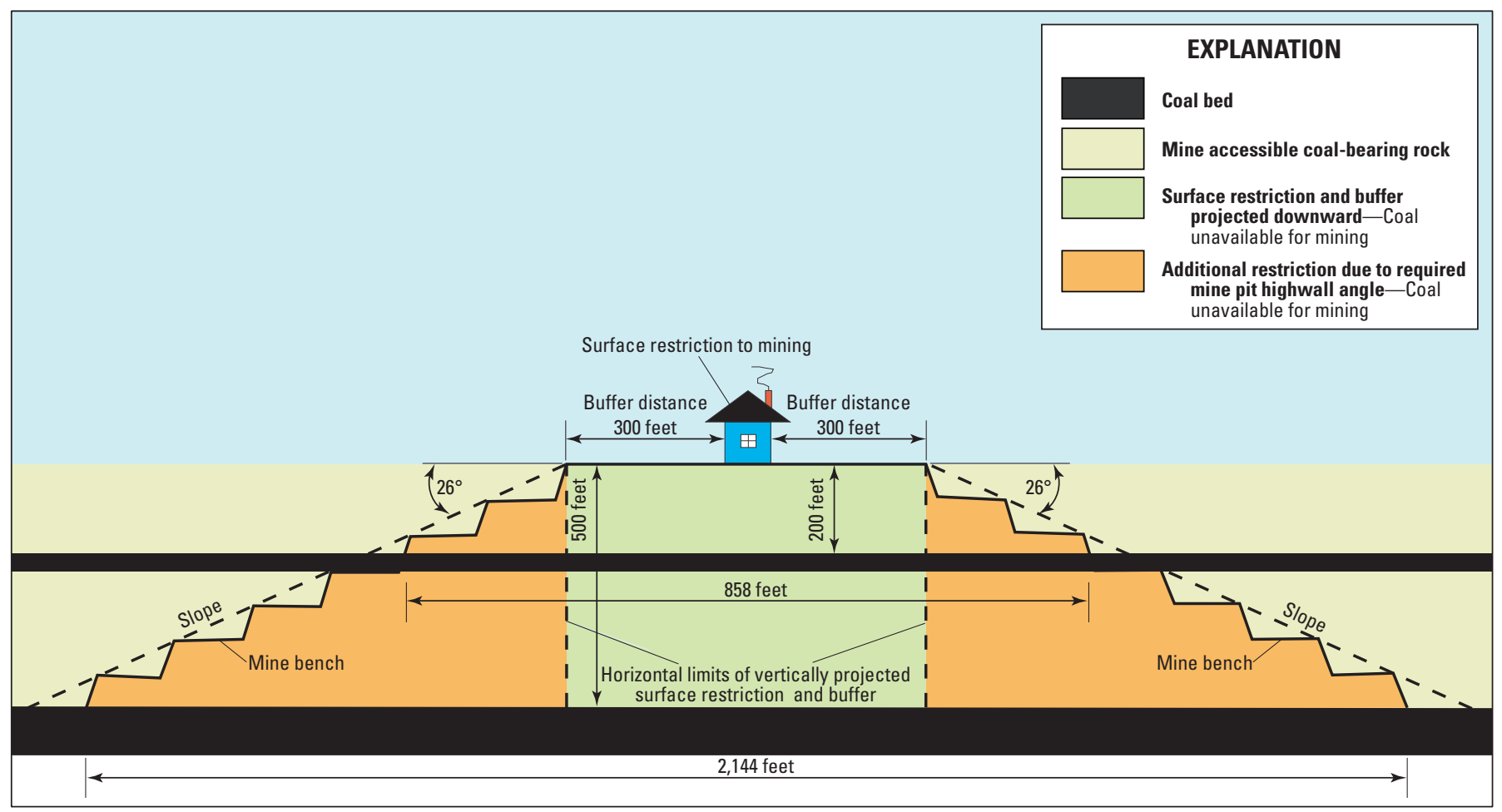

NOT TO SCALE

Figure 104. Effect of coal bed depth upon restricted resource from mine-pit highwall setback requirements.

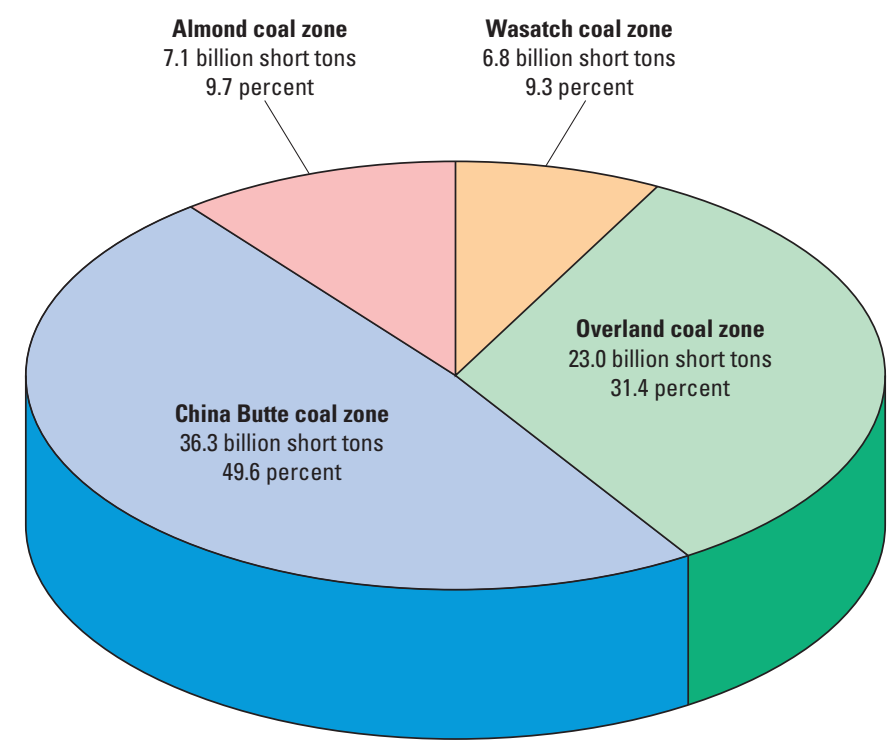

Figure 105. Tonnages and percentages of coal zones in relation to the 73.2 billion short tons of original resources in the Little Snake River coal field and Red Desert assessment area, Greater Green River Basin, Wyoming. 


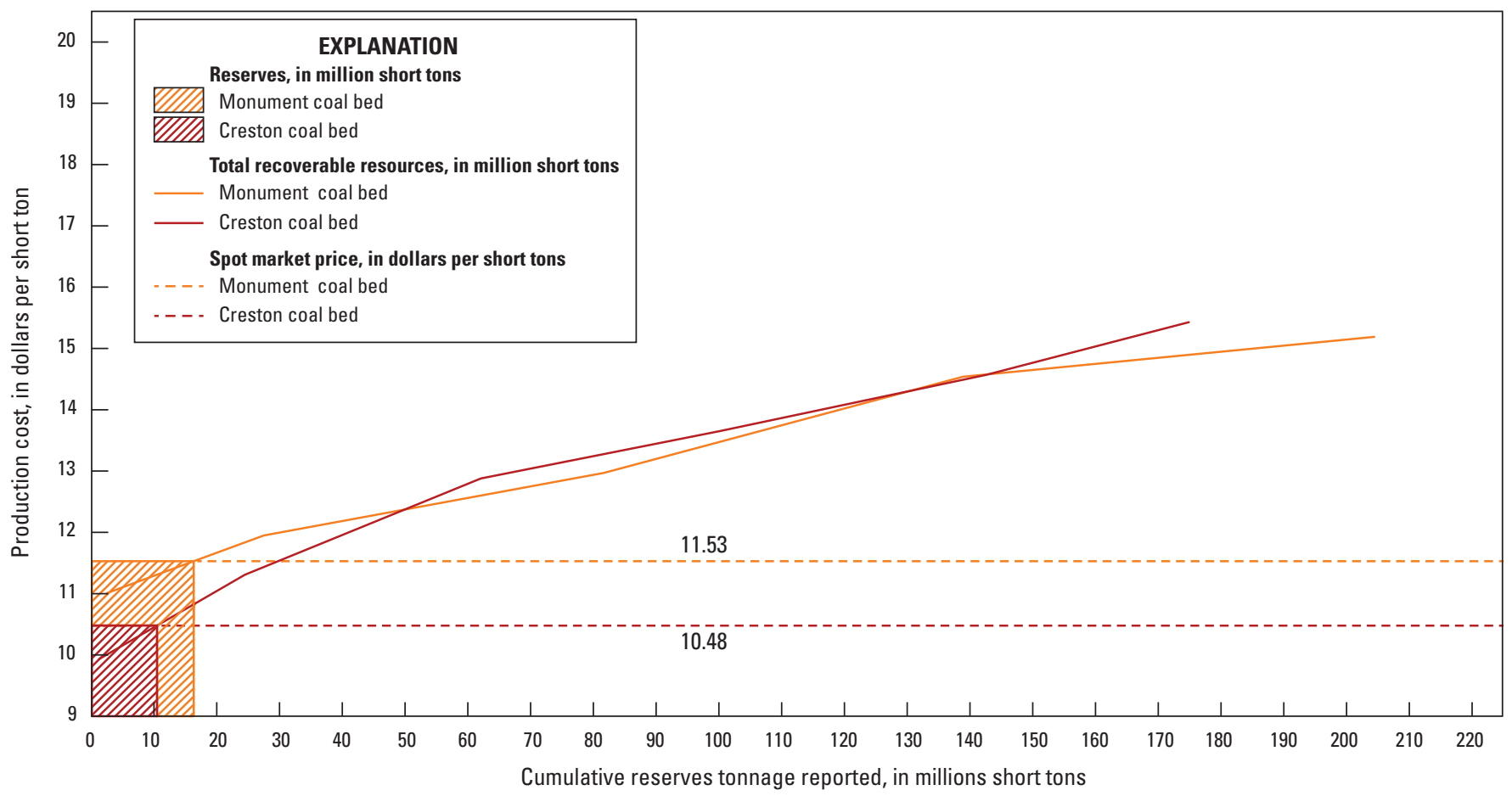

Figure 106. Cumulative cost curve for two coal beds in the Wasatch coal zone, using sales price per short ton to delineate recoverable resources and reserves. Hatched areas indicate reserves, in million short tons, are as follows: Monument coal bed, 16.3; and Creston coal bed, 10.4 .

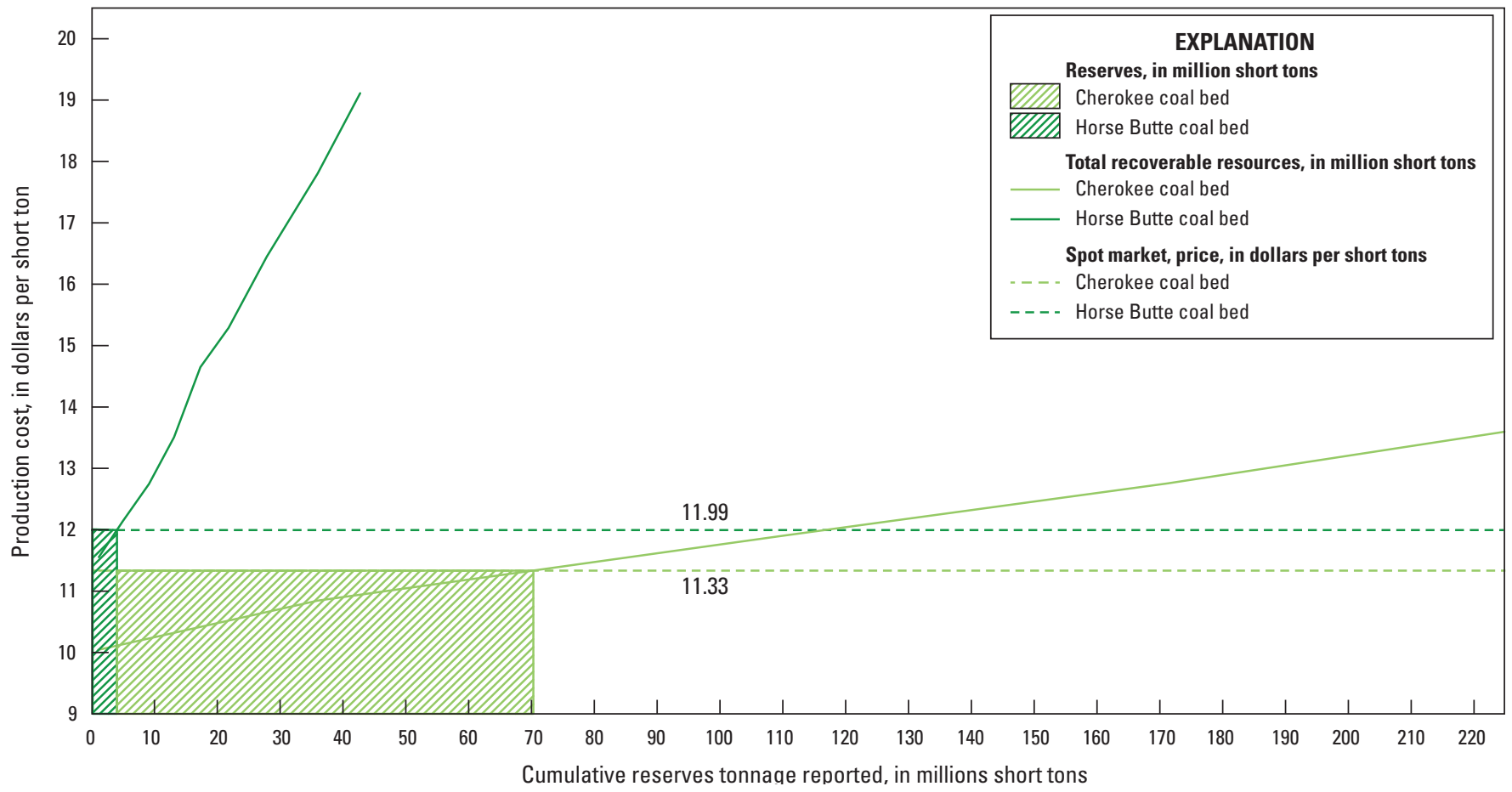

Figure 107. Cumulative cost curve for two coal beds in the Overland coal zone, using sales price per short ton to delineate recoverable resources and reseves. Hatched areas indicate reserves, in million short tons, are as follows: Cherokee coal bed, 70.3; and Horse Butte coal bed, 3.9. 


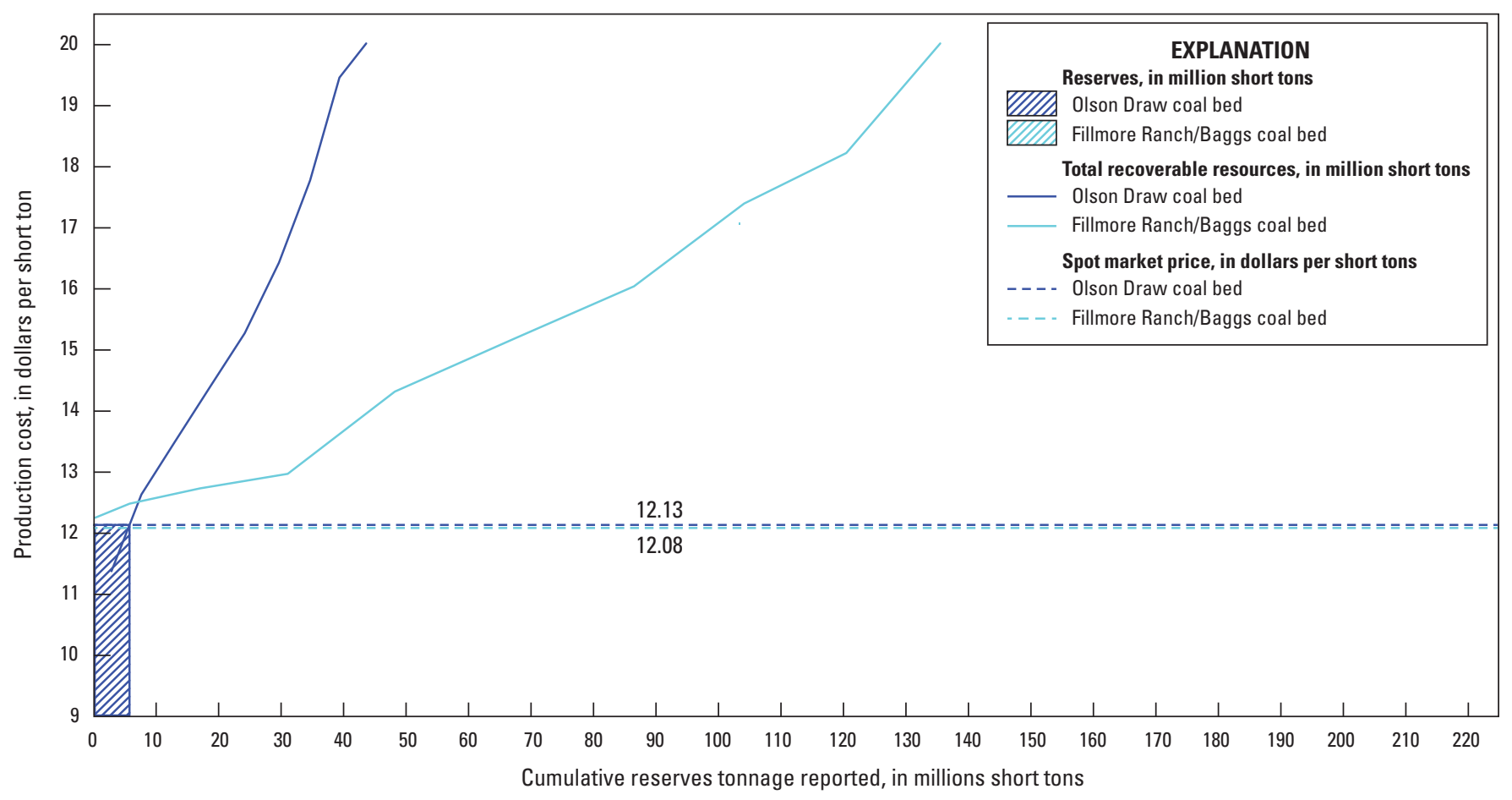

Figure 108. Cumulative cost curve for two coal beds in the China Butte coal zone, using sales price per short ton to delineate recoverable resources and reserves. Hatched areas indicate reserves. Reserves, in million shor tons, are as follows: Fillmore Ranch/ Baggs coal bed, 0; Olson Draw coal bed, 5.5 .

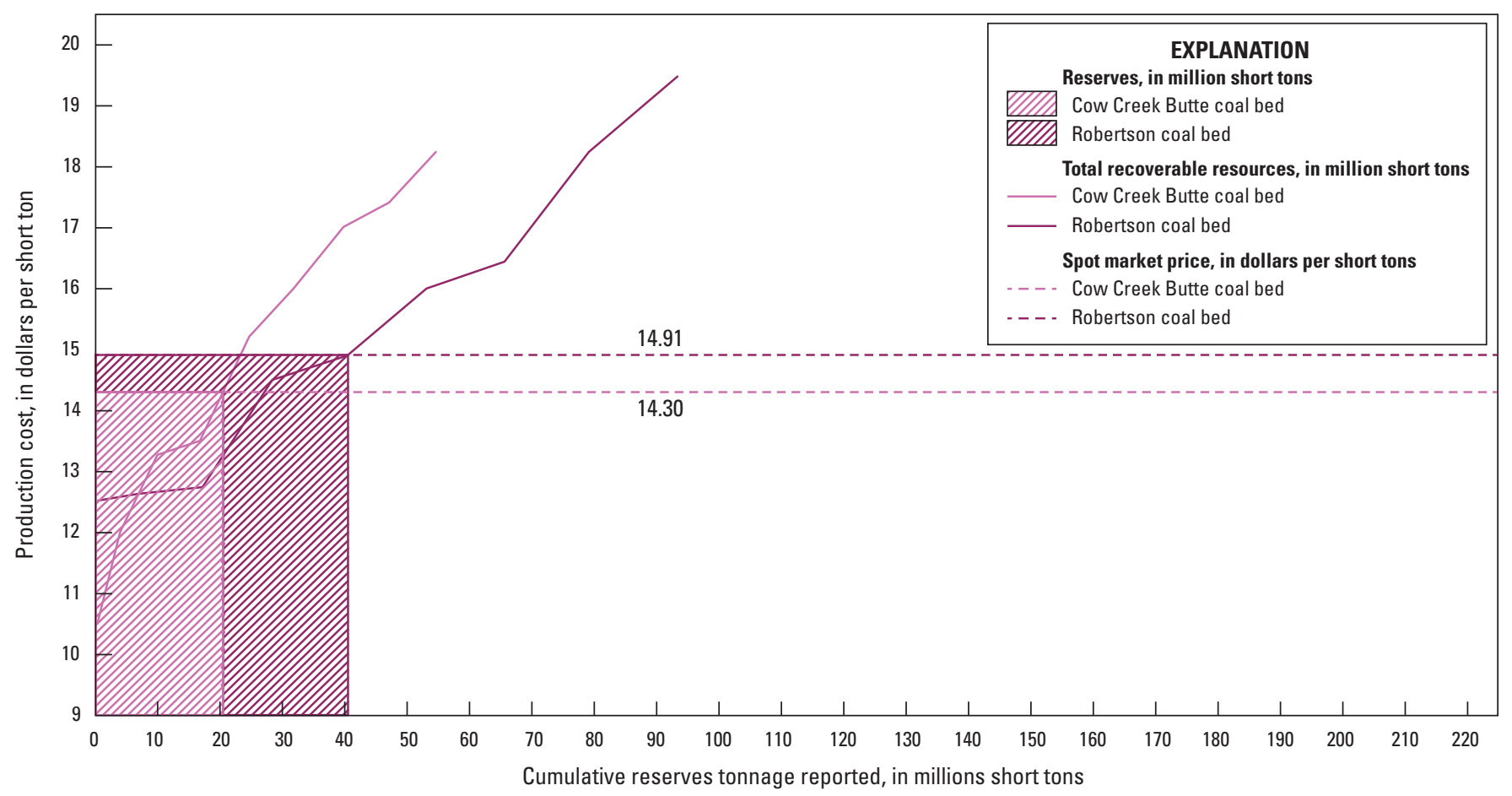

Figure 109. Cumulative cost curve for two coal beds in the Almond coal zone. Reserves, in million short tons, are as follows: Cow Creek Butte coal bed, 40.4; Robertson, 20.4. 


\section{Original Coal Resources}

In-place coal resources prior to mining activities that are less than 6,000 feet deep; anthracite and bituminous coal greater than 14 inches thick subbituminous coal and lignite less than 30 inches thick

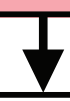

Subtract: coal resources that have been previously extracted and coal resources left as pillars or barriers or that have been otherwise sterilized by previous mining activities

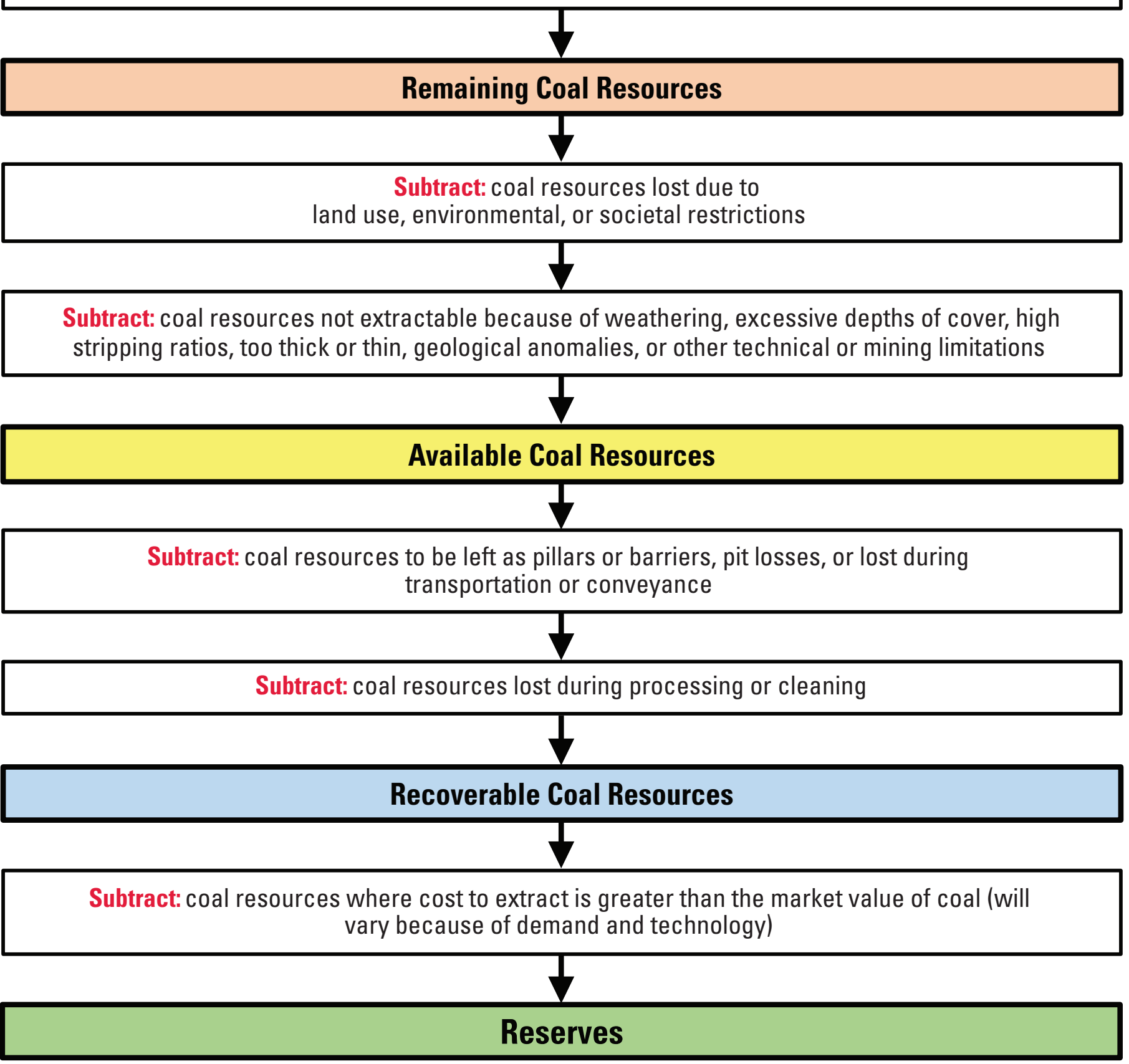

Figure 110. Classification of coal resources and reserves used by the U.S. Geological Survey in coal assessment studies (from Luppens and others, 2009). 



\section{Tables}


Table 1. Original surface and underground resources in the Little Snake River coal field and Red Desert assessment area, Greater Green River Basin, Wyoming.

[Values reported in short tons. Surface resources are for coal beds with cover from 0 to 200 feet deep. Underground resources are for coal beds with cover from 200 to 3,000 feet deep. Resources are for 23 U.S. Geological Survey 7.5-minute quadrangles (Dames and Moore Company, 1978a-g, 1979a-p). -, not applicable]

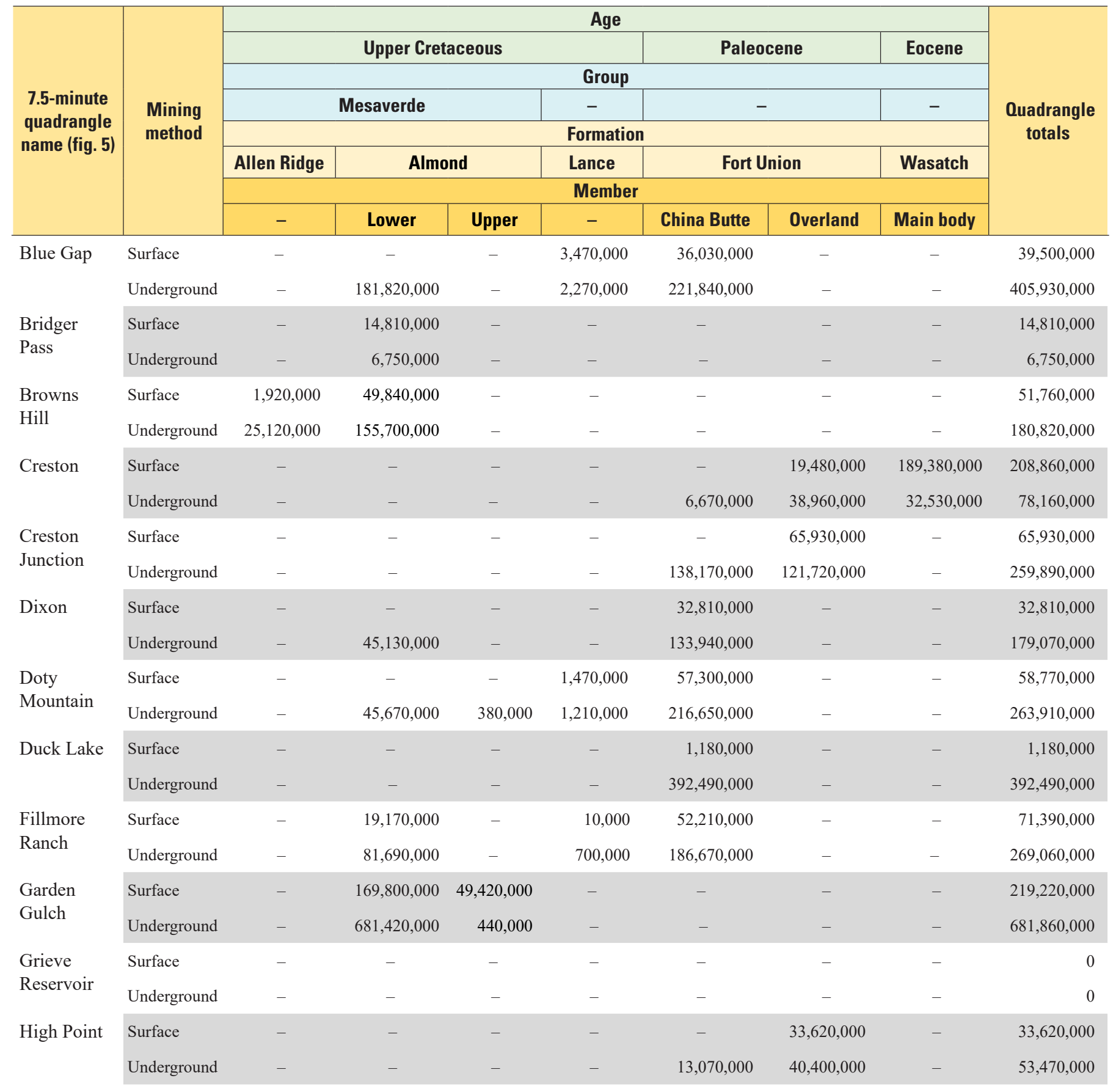


Table 1. Original surface and underground resources in the Little Snake River coal field and Red Desert assessment area, Greater Green River Basin, Wyoming.-Continued

[Values reported in short tons. Surface resources are for coal beds with cover from 0 to 200 feet deep. Underground resources are for coal beds with cover from 200 to 3,000 feet deep. Resources are for 23 U.S. Geological Survey 7.5-minute quadrangles (Dames and Moore Company, 1978a-g, 1979a-p). -, not applicable]_Continued

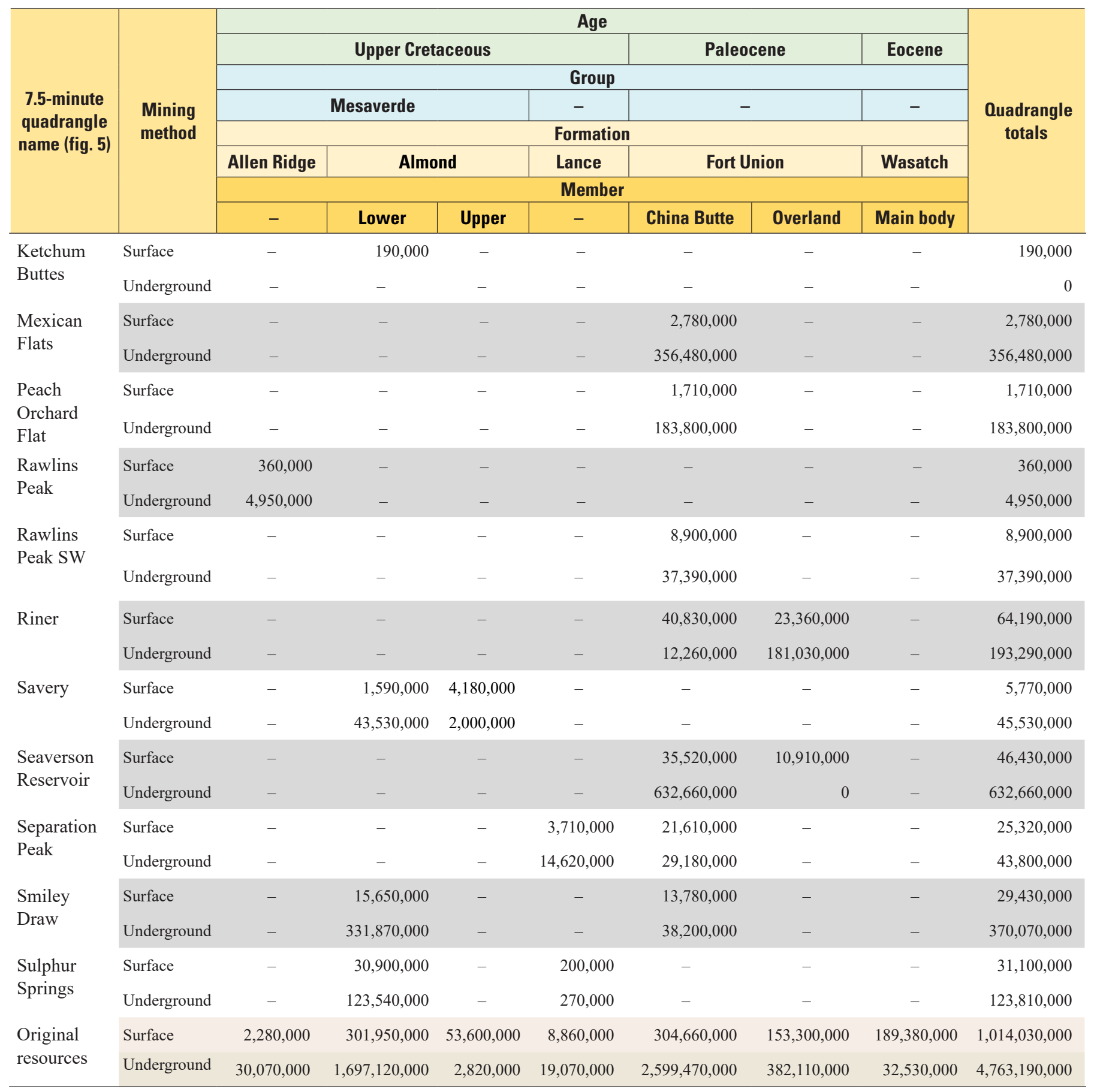


Table 2. Typical proximate analysis on a raw, as-received basis reporting calorific value, moisture, sulfur, ash, fixed carbon, and volatile matter for coal beds in the Little Snake River coal field and Red Desert assessment area, Greater Green River Basin, Wyoming.

[All data are from Anadarko Land Corporation, (2013). Btu/lb, British thermal unit per pound; \%, percent; sub, subbituminous; hvCb, high volatile C bituminous; NA, not applicable]

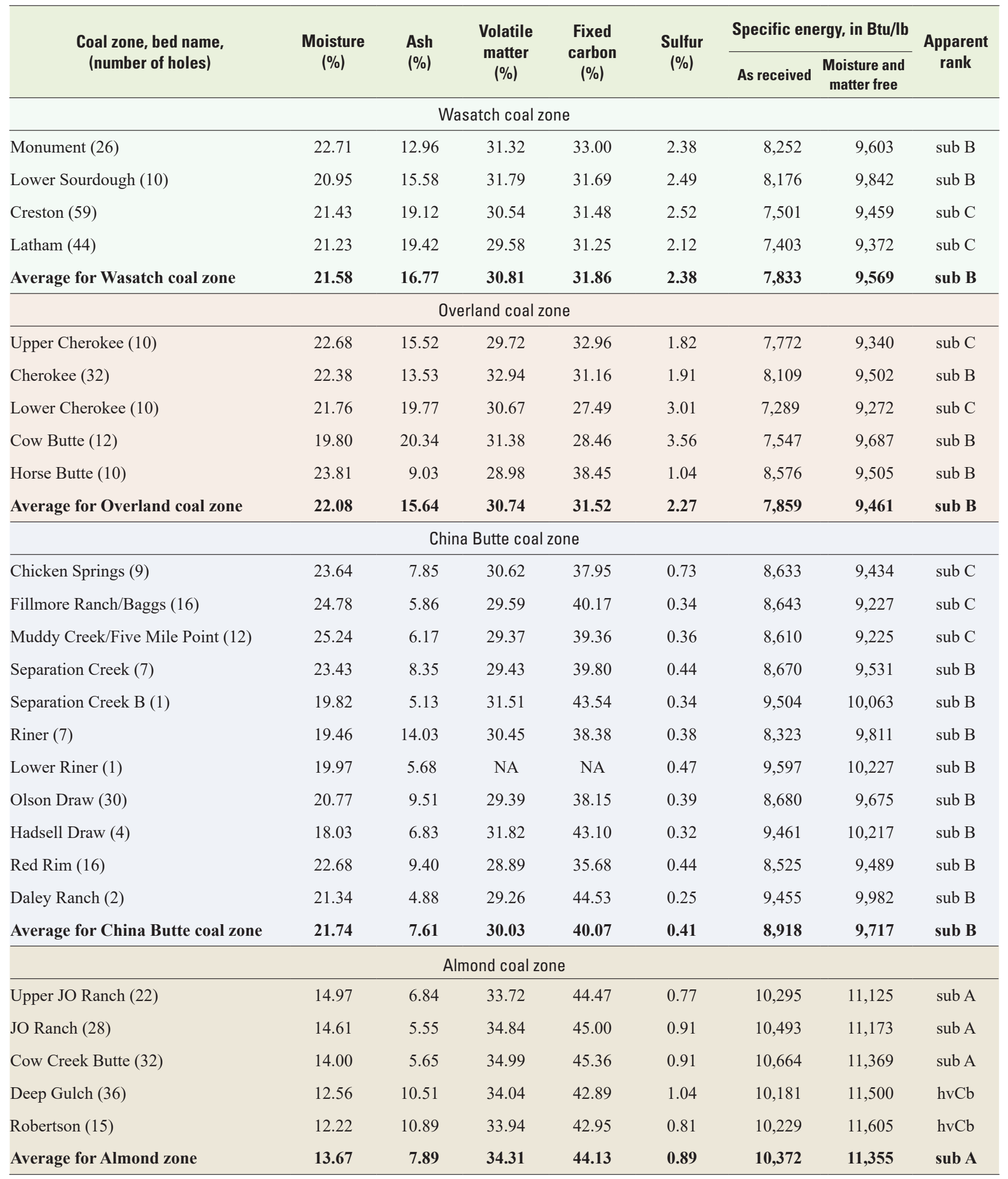


Table 3. Original coal resources, recoverable coal resources, restrictions, and reliability classifications for 33 coal beds in the Little Snake River coal field and Red Desert assessment area, Greater Green River Basin, Wyoming.

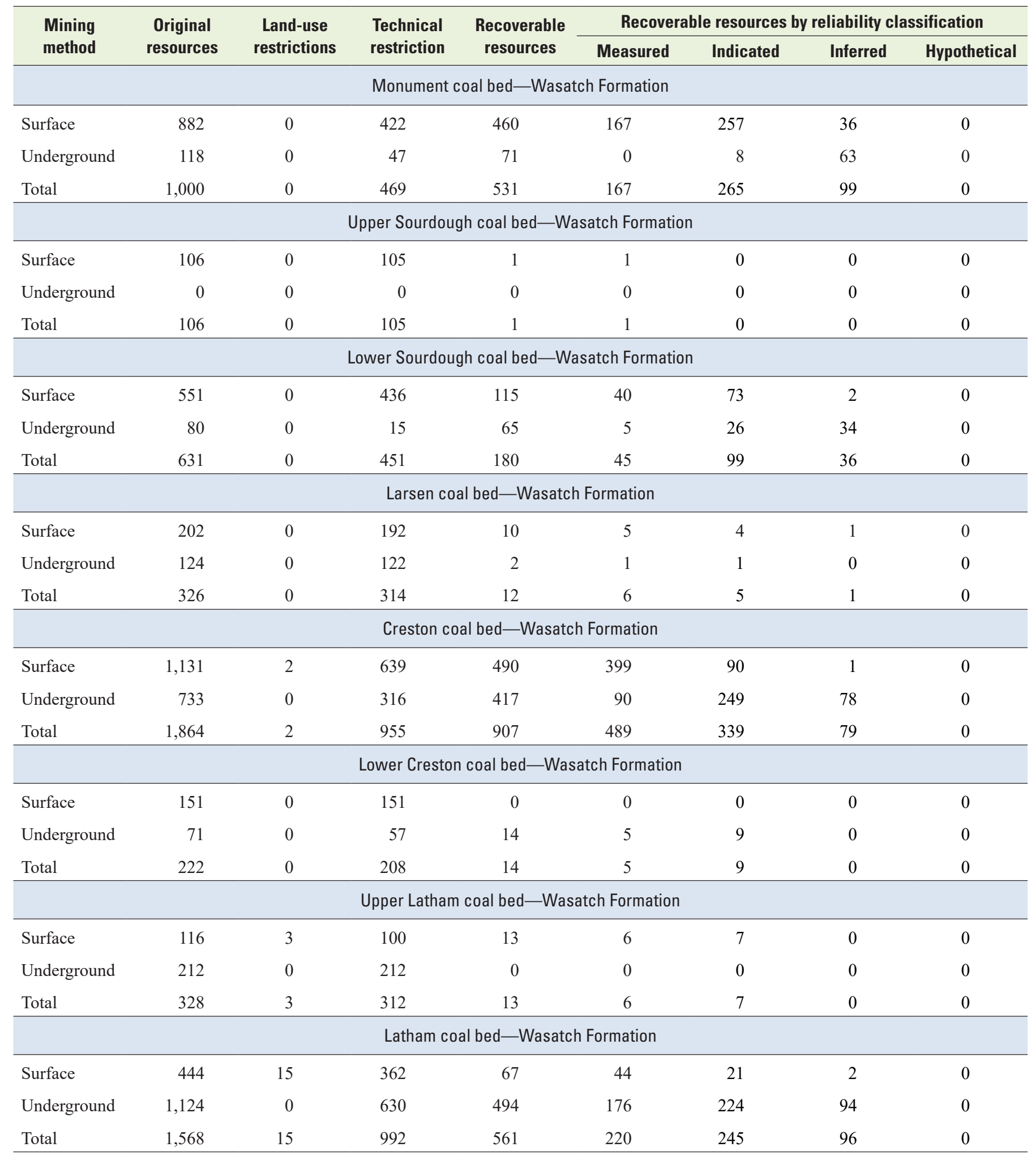


Table 3. Original coal resources, recoverable coal resources, restrictions, and reliability classifications for 33 coal beds in the Little Snake River coal field and Red Desert assessment area, Greater Green River Basin, Wyoming._-Continued

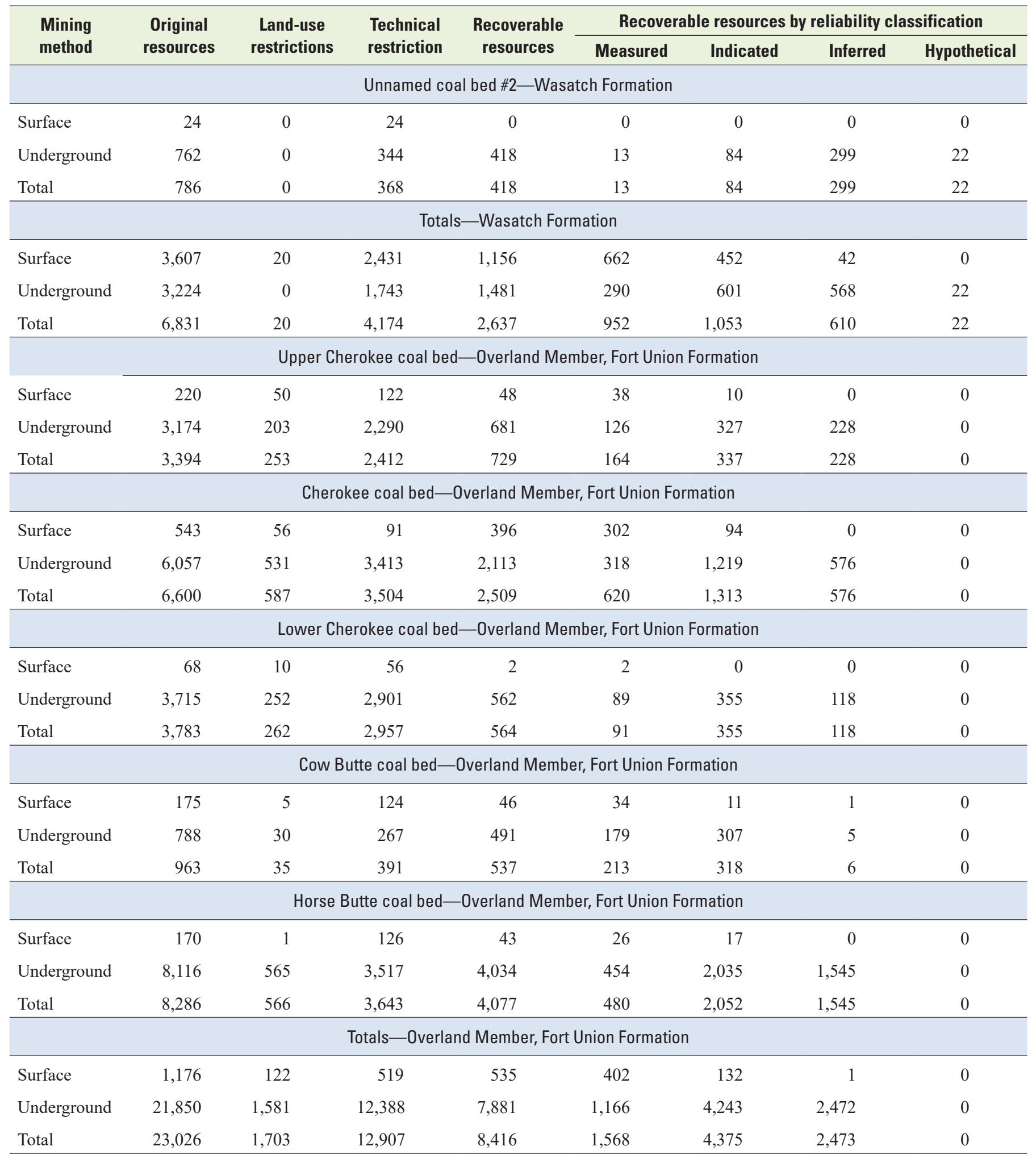


Table 3. Original coal resources, recoverable coal resources, restrictions, and reliability classifications for 33 coal beds in the Little Snake River coal field and Red Desert assessment area, Greater Green River Basin, Wyoming._-Continued

\begin{tabular}{|c|c|c|c|c|c|c|c|c|}
\hline \multirow{2}{*}{$\begin{array}{l}\text { Mining } \\
\text { method }\end{array}$} & \multirow{2}{*}{$\begin{array}{l}\text { Original } \\
\text { resources }\end{array}$} & \multirow{2}{*}{$\begin{array}{l}\text { Land-use } \\
\text { restrictions }\end{array}$} & \multirow{2}{*}{$\begin{array}{l}\text { Technical } \\
\text { restriction }\end{array}$} & \multirow{2}{*}{$\begin{array}{c}\text { Recoverable } \\
\text { resources }\end{array}$} & \multicolumn{4}{|c|}{ Recoverable resources by reliability classification } \\
\hline & & & & & Measured & Indicated & Inferred & Hypothetical \\
\hline \multicolumn{9}{|c|}{ Chicken Springs coal bed-China Butte Member, Fort Union Formation } \\
\hline Surface & 66 & 1 & 55 & 10 & 10 & 0 & 0 & 0 \\
\hline Underground & 979 & 9 & 866 & 104 & 10 & 45 & 49 & 0 \\
\hline \multicolumn{9}{|c|}{ Fillmore Ranch/Baggs coal bed-China Butte Member, Fort Union Formation } \\
\hline Surface & 213 & 4 & 73 & 136 & 106 & 30 & 0 & 0 \\
\hline Underground & 9,454 & 265 & 6,802 & 2,387 & 353 & 1,396 & 637 & 1 \\
\hline Total & 9,667 & 269 & 6,875 & 2,523 & 459 & 1,426 & 637 & 1 \\
\hline Underground & 1,495 & 93 & 1,400 & 2 & 2 & 0 & 0 & 0 \\
\hline Total & 1,502 & 93 & 1,407 & 2 & 2 & 0 & 0 & 0 \\
\hline \multicolumn{9}{|c|}{ Muddy Creek/Five Mile Point coal bed-China Butte Member, Fort Union Formation } \\
\hline Surface & 78 & 1 & 69 & 8 & 8 & 0 & 0 & 0 \\
\hline Underground & 3,841 & 409 & 2,846 & 586 & 119 & 361 & 107 & 0 \\
\hline Total & 3,919 & 410 & 2,915 & 594 & 127 & 361 & 107 & 0 \\
\hline \multicolumn{9}{|c|}{ Separation Creek B coal bed-China Butte Member, Fort Union Formation } \\
\hline Surface & 11 & 0 & 10 & 1 & 1 & 0 & 0 & 0 \\
\hline Underground & 994 & 20 & 974 & 0 & 0 & 0 & 0 & 0 \\
\hline Total & 1,013 & 20 & 991 & 2 & 2 & 0 & 0 & 0 \\
\hline \multicolumn{9}{|c|}{ Riner coal bed-China Butte Member, Fort Union Formation } \\
\hline Surface & 28 & 0 & 23 & 5 & 2 & 0 & 3 & 0 \\
\hline Underground & 1,078 & 83 & 920 & 75 & 44 & 29 & 2 & 0 \\
\hline Total & 1,106 & 83 & 943 & 80 & 46 & 29 & 5 & 0 \\
\hline \multicolumn{9}{|c|}{ Lower Riner coal bed_China Butte Member, Fort Union Formation } \\
\hline Surface & 3 & 0 & 3 & 0 & 0 & 0 & 0 & 0 \\
\hline Underground & 4,040 & 421 & 3,571 & 48 & 19 & 29 & 0 & 0 \\
\hline Total & 4,043 & 421 & 3,574 & 48 & 19 & 29 & 0 & 0 \\
\hline
\end{tabular}


Table 3. Original coal resources, recoverable coal resources, restrictions, and reliability classifications for 33 coal beds in the Little Snake River coal field and Red Desert assessment area, Greater Green River Basin, Wyoming._-Continued

\begin{tabular}{|c|c|c|c|c|c|c|c|c|}
\hline \multirow{2}{*}{$\begin{array}{l}\text { Mining } \\
\text { method }\end{array}$} & \multirow{2}{*}{$\begin{array}{c}\text { Original } \\
\text { resources }\end{array}$} & \multirow{2}{*}{$\begin{array}{l}\text { Land-use } \\
\text { restrictions }\end{array}$} & \multirow{2}{*}{$\begin{array}{l}\text { Technical } \\
\text { restriction }\end{array}$} & \multirow{2}{*}{$\begin{array}{l}\text { Recoverable } \\
\text { resources }\end{array}$} & \multicolumn{4}{|c|}{ Recoverable resources by reliability classification } \\
\hline & & & & & Measured & Indicated & Inferred & Hypothetical \\
\hline \multicolumn{9}{|c|}{ Wild Cow coal bed-China Butte Member, Fort Union Formation } \\
\hline Surface & 14 & 0 & 12 & 2 & 2 & 0 & 0 & 0 \\
\hline Underground & 569 & 0 & 357 & 212 & 12 & 68 & 132 & 0 \\
\hline \multicolumn{9}{|c|}{ Olson Draw coal bed-China Butte Member, Fort Union Formation } \\
\hline Surface & 134 & 14 & 76 & 44 & 39 & 4 & 0 & 0 \\
\hline Underground & 4,605 & 187 & 2,401 & 2,017 & 318 & 896 & 776 & 27 \\
\hline Total & 4,739 & 201 & 2,477 & 2,061 & 357 & 900 & 776 & 27 \\
\hline Underground & 457 & 2 & 384 & 71 & 11 & 43 & 17 & 0 \\
\hline Total & 463 & 2 & 389 & 72 & 12 & 43 & 17 & 0 \\
\hline \multicolumn{9}{|c|}{ Red Rim coal bed-China Butte Member, Fort Union Formation } \\
\hline Surface & 76 & 3 & 55 & 18 & 16 & 2 & 0 & 0 \\
\hline Underground & 3,443 & 298 & 2,684 & 461 & 55 & 211 & 195 & 0 \\
\hline Total & 3,519 & 301 & 2,739 & 479 & 71 & 213 & 195 & 0 \\
\hline \multicolumn{9}{|c|}{ Daley Ranch coal bed-China Butte Member, Fort Union Formation } \\
\hline Surface & 14 & 1 & 12 & 1 & 1 & 0 & 0 & 0 \\
\hline Underground & 35,590 & 2,298 & 27,203 & 6,089 & 1,016 & 3,131 & 1,915 & 28 \\
\hline Total & 36,259 & 2,322 & 27,620 & 6,317 & 1,204 & 3,167 & 1,918 & 28 \\
\hline \multicolumn{9}{|c|}{ Garden Gulch coal bed-Almond Formation, Mesaverde Group } \\
\hline Surface & 136 & 0 & 109 & 27 & 12 & 16 & 0 & 0 \\
\hline Underground & 12 & 0 & 12 & 0 & 0 & 0 & 0 & 0 \\
\hline Total & 148 & 0 & 121 & 27 & 12 & 16 & 0 & 0 \\
\hline \multicolumn{9}{|c|}{ Upper JO Ranch coal bed-Almond Formation, Mesaverde Group } \\
\hline Surface & 159 & 0 & 145 & 14 & 3 & 7 & 4 & 0 \\
\hline Underground & 92 & 0 & 90 & 2 & 2 & 0 & 0 & 0 \\
\hline Total & 251 & 0 & 235 & 16 & 5 & 7 & 4 & 0 \\
\hline
\end{tabular}


Table 3. Original coal resources, recoverable coal resources, restrictions, and reliability classifications for 33 coal beds in the Little Snake River coal field and Red Desert assessment area, Greater Green River Basin, Wyoming._-Continued

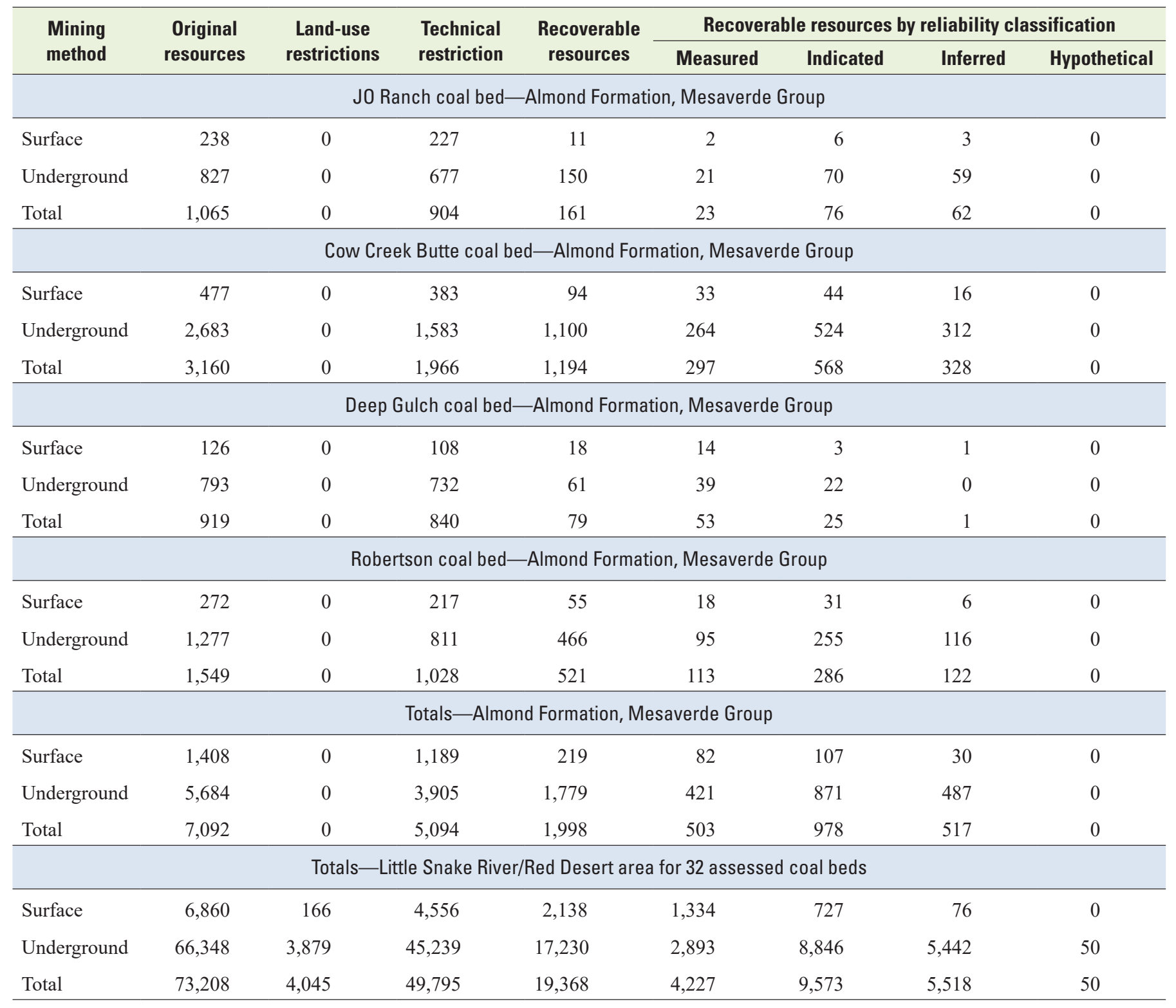


Table 4. Recoverable coal resources and classification by coal ownership for 33 coal beds in the Little Snake River coal field and Red Desert assessment area, Greater Green River Basin, Wyoming.

[Note, recoverable resources referenced from table 3]

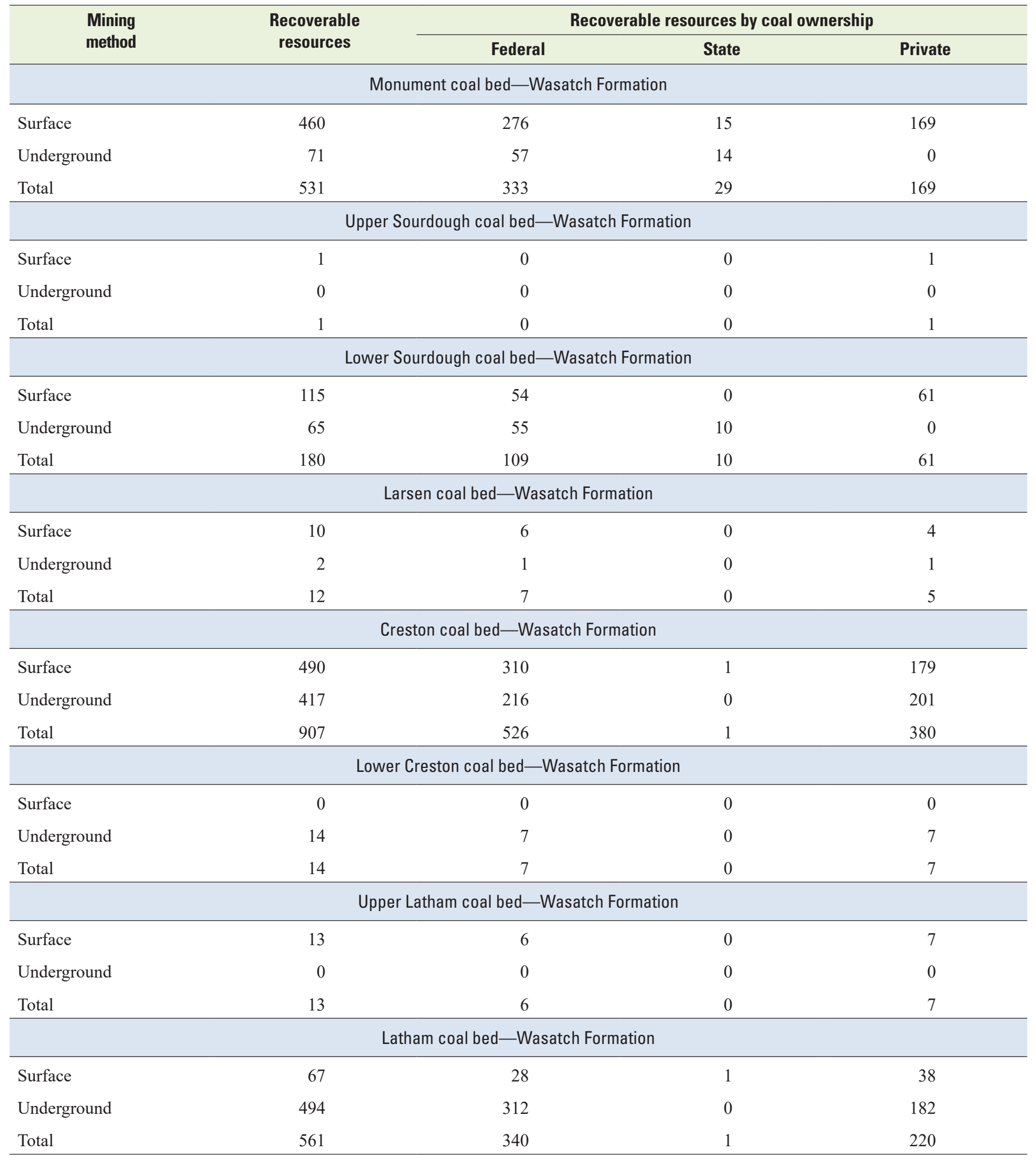


Table 4. Recoverable coal resources and classification by coal ownership for 33 coal beds in the Little Snake River coal field and Red Desert assessment area, Greater Green River Basin, Wyoming._-Continued

[Note, recoverable resources referenced from table 3]

\begin{tabular}{|c|c|c|c|c|}
\hline \multirow{2}{*}{$\begin{array}{l}\text { Mining } \\
\text { method }\end{array}$} & \multirow{2}{*}{$\begin{array}{c}\text { Recoverable } \\
\text { resources }\end{array}$} & \multicolumn{3}{|c|}{ Recoverable resources by coal ownership } \\
\hline & & Federal & State & Private \\
\hline \multicolumn{5}{|c|}{ Unnamed coal bed \#2-Wasatch Formation } \\
\hline Surface & 0 & 0 & 0 & 0 \\
\hline Underground & 418 & 261 & 1 & 156 \\
\hline \multicolumn{5}{|c|}{ Totals-Wasatch Formation } \\
\hline Surface & 1,156 & 680 & 17 & 459 \\
\hline Underground & 1,481 & 909 & 25 & 547 \\
\hline Total & 2,637 & 1,589 & 42 & 1,006 \\
\hline Underground & 681 & 404 & 1 & 276 \\
\hline Total & 729 & 431 & 2 & 296 \\
\hline \multicolumn{5}{|c|}{ Cherokee coal bed-Overland Mbr, Fort Union Fm } \\
\hline Surface & 396 & 207 & 2 & 187 \\
\hline Underground & 2,113 & 1,144 & 18 & 951 \\
\hline Total & 2,509 & 1,351 & 20 & 1,138 \\
\hline \multicolumn{5}{|c|}{ Lower Cherokee coal bed-Overland Mbr, Fort Union Fm } \\
\hline Surface & 2 & 1 & 0 & 1 \\
\hline Underground & 491 & 252 & 0 & 239 \\
\hline Total & 537 & 275 & 1 & 261 \\
\hline \multicolumn{5}{|c|}{ Horse Butte coal bed-Overland Mbr, Fort Union Fm } \\
\hline Surface & 43 & 16 & 6 & 21 \\
\hline Underground & 4,034 & 2,197 & 40 & 1,797 \\
\hline Total & 4,077 & 2,213 & 46 & 1,818 \\
\hline \multicolumn{5}{|c|}{ Totals-Overland Member, Fort Union Formation } \\
\hline Surface & 535 & 274 & 10 & 251 \\
\hline Underground & 7,881 & 4,286 & 71 & 3,524 \\
\hline Total & 8,416 & 4,560 & 81 & 3,775 \\
\hline
\end{tabular}


Table 4. Recoverable coal resources and classification by coal ownership for 33 coal beds in the Little Snake River coal field and Red Desert assessment area, Greater Green River Basin, Wyoming._-Continued

[Note, recoverable resources referenced from table 3]

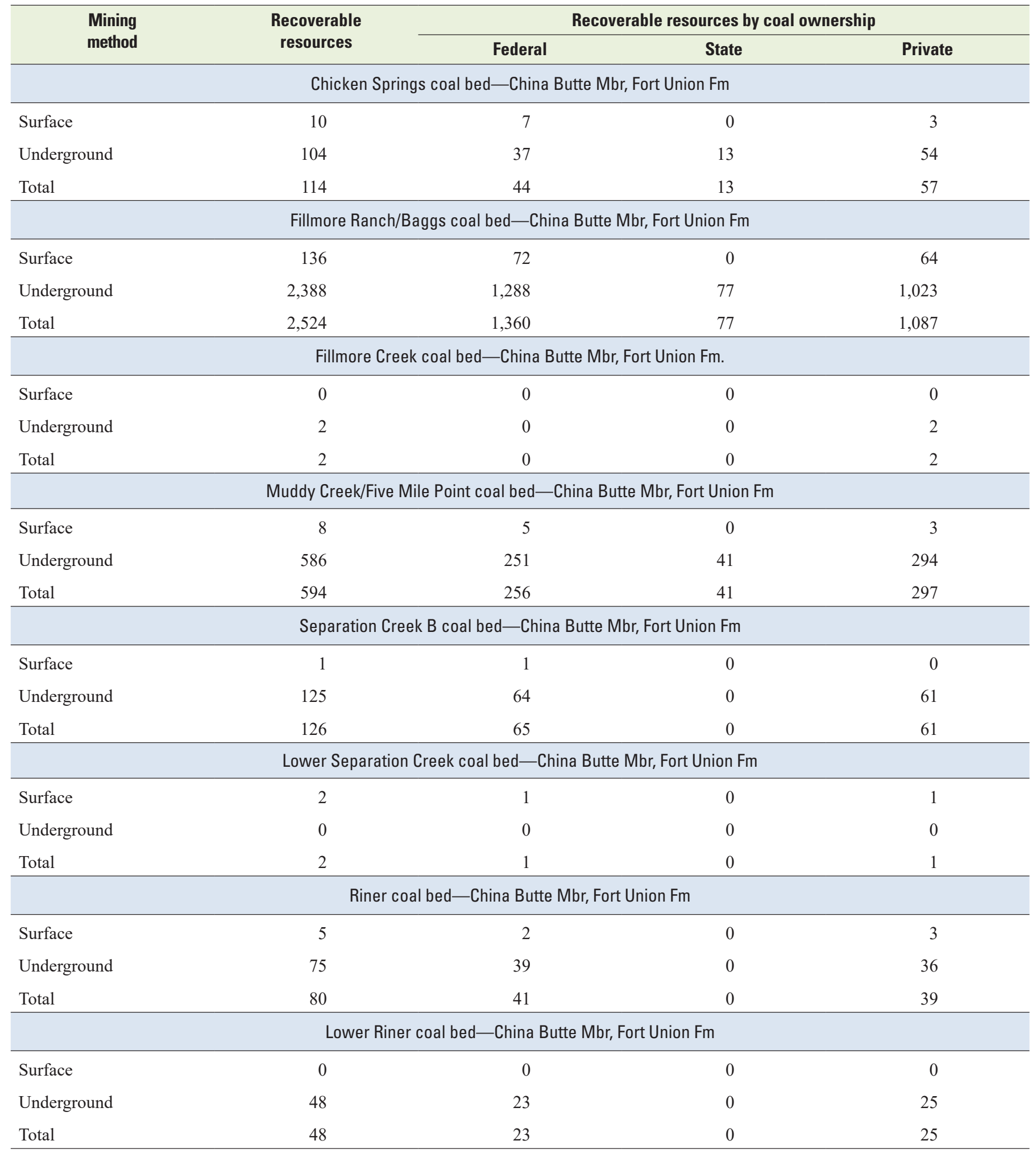


Table 4. Recoverable coal resources and classification by coal ownership for 33 coal beds in the Little Snake River coal field and Red Desert assessment area, Greater Green River Basin, Wyoming.-Continued

[Note, recoverable resources referenced from table 3]

\begin{tabular}{|c|c|c|c|c|}
\hline \multirow{2}{*}{$\begin{array}{l}\text { Mining } \\
\text { method }\end{array}$} & \multirow{2}{*}{$\begin{array}{l}\text { Recoverable } \\
\text { resources }\end{array}$} & \multicolumn{3}{|c|}{ Recoverable resources by coal ownership } \\
\hline & & Federal & State & Private \\
\hline \multicolumn{5}{|c|}{ Wild Cow coal bed_-China Butte Mbr, Fort Union Fm } \\
\hline Surface & 2 & 0 & 0 & 2 \\
\hline Underground & 212 & 104 & 2 & 106 \\
\hline \multicolumn{5}{|c|}{ Olson Draw coal bed_-China Butte Mbr, Fort Union Fm } \\
\hline Surface & 44 & 30 & 1 & 13 \\
\hline Underground & 2,017 & 945 & 102 & 970 \\
\hline Total & 2,061 & 975 & 103 & 983 \\
\hline Underground & 71 & 45 & 6 & 20 \\
\hline Total & 72 & 46 & 6 & 20 \\
\hline \multicolumn{5}{|c|}{ Red Rim coal bed-China Butte Mbr, Fort Union Fm } \\
\hline Surface & 18 & 8 & 2 & 8 \\
\hline Underground & 461 & 199 & 26 & 236 \\
\hline Total & 479 & 207 & 28 & 244 \\
\hline \multicolumn{5}{|c|}{ Daley Ranch coal bed-China Butte Mbr, Fort Union Fm } \\
\hline Surface & 1 & 1 & 0 & 0 \\
\hline Underground & 6,090 & 2,996 & 267 & 2,827 \\
\hline Total & 6,318 & 3,124 & 270 & 2,924 \\
\hline \multicolumn{5}{|c|}{ Garden Gulch coal bed_Almond Fm, Mesaverde Group } \\
\hline Surface & 27 & 27 & 0 & 0 \\
\hline Underground & 0 & 0 & 0 & 0 \\
\hline Total & 27 & 27 & 0 & 0 \\
\hline \multicolumn{5}{|c|}{ Upper JO Ranch coal bed-Almond Fm, Mesaverde Group } \\
\hline Surface & 14 & 13 & 0 & 1 \\
\hline Underground & 2 & 2 & 0 & 0 \\
\hline Total & 16 & 15 & 0 & 1 \\
\hline
\end{tabular}


Table 4. Recoverable coal resources and classification by coal ownership for 33 coal beds in the Little Snake River coal field and Red Desert assessment area, Greater Green River Basin, Wyoming._-Continued

[Note, recoverable resources referenced from table 3]

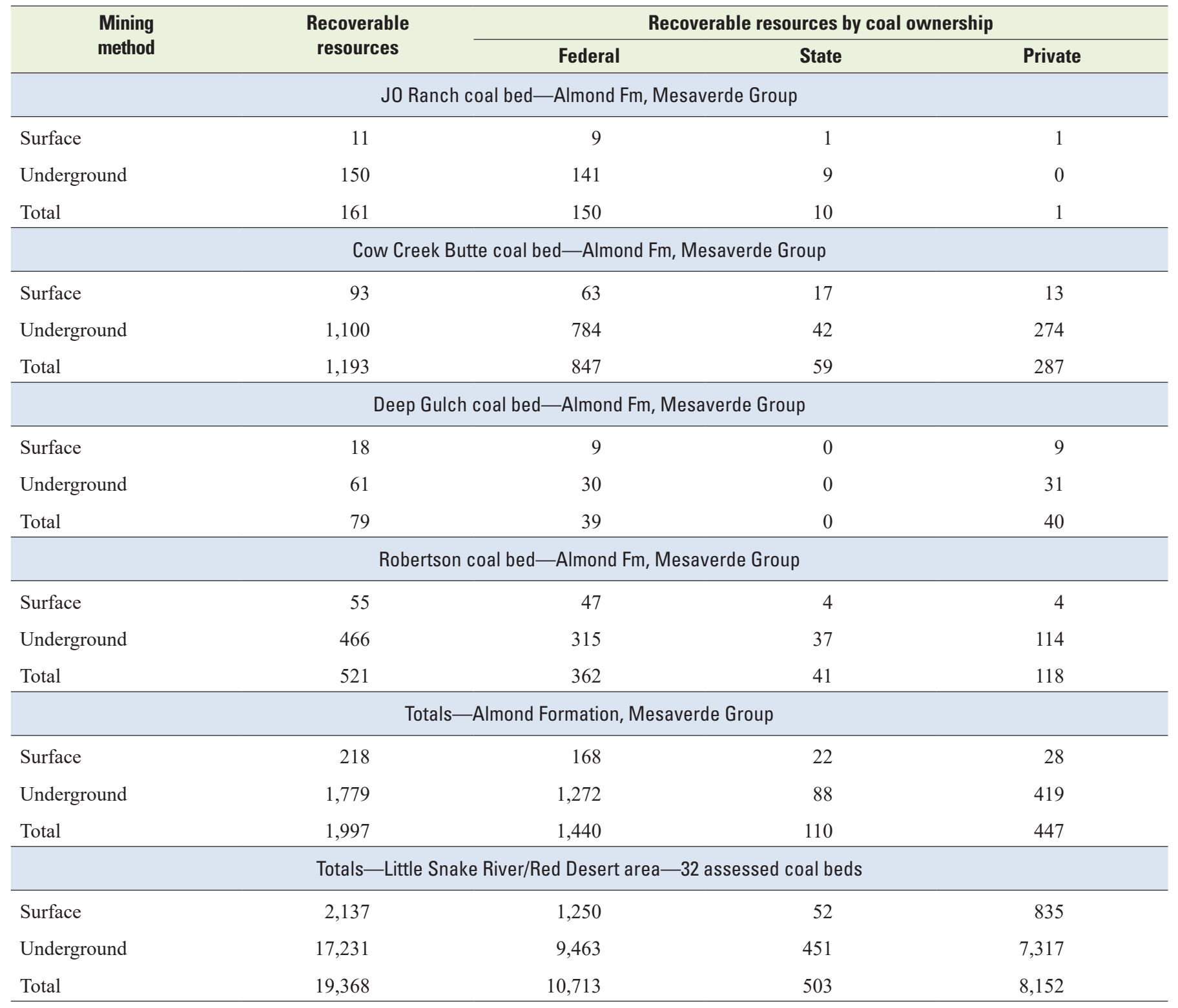


Table 5. Summary of original and recoverable coal resources, restrictions, reliability classifications, and geologic uinti for 33 coal beds in the Little Snake River coal field and Red Desert assessment area, Greater Green River Basin Wyoming.

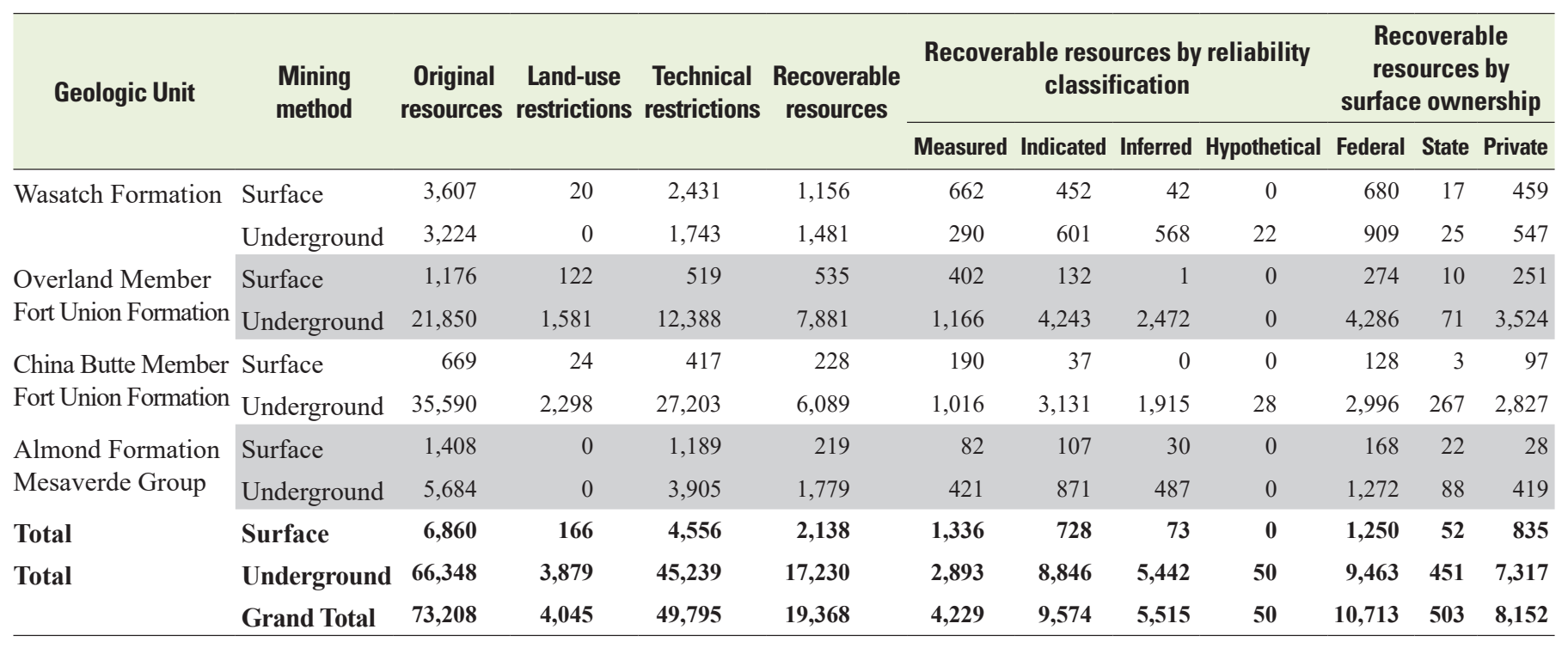

Table 6. Projected surface mine breakeven costs and estimated prices for run-of-mine coal for coal beds in the Little Snake River coal field and Red Desert assessment area, Greater Green River Basin, Wyoming.

[Green-shaded values represents breakeven cost of production is less than spot market price per short ton, economic-classified as a reserve; weathered represents all coal resources within this stripping ratio increment are within the weathered or oxidized zone within 25 feet of the surface; all other values represent all coal resources within this stripping ratio increment are within the weathered or oxidized zone within 25 feet of the surface]

\begin{tabular}{|c|c|c|c|c|c|c|c|c|c|c|c|}
\hline \multirow{2}{*}{ Coal bed name } & \multicolumn{10}{|c|}{ Breakeven cost by stripping ratio increment (dollars) } & \multirow{2}{*}{$\begin{array}{l}\text { Price (dollar } \\
\text { per short ton) }\end{array}$} \\
\hline & 1 & 2 & 3 & 4 & 5 & 6 & 7 & 8 & 9 & 10 & \\
\hline \multicolumn{12}{|c|}{ Wasatch Formation } \\
\hline Lower Sourdough & weathered & weathered & 11.73 & 12.74 & 13.50 & 14.41 & 15.28 & 16.44 & 17.79 & 20.30 & $\$ 11.43$ \\
\hline Creston & 9.93 & 11.31 & 12.88 & 13.65 & 14.57 & 15.43 & 16.59 & 18.39 & 19.63 & 21.32 & $\$ 10.48$ \\
\hline \multicolumn{12}{|c|}{ Overland Member, Fort Union Formation } \\
\hline Upper Cherokee & weathered & 11.56 & 12.22 & 12.92 & 13.68 & 14.62 & 15.28 & 16.44 & 17.41 & 18.24 & $\$ 10.86$ \\
\hline Cherokee & 10.04 & 10.84 & 11.90 & 12.75 & 13.59 & 15.34 & 16.00 & 16.97 & 18.24 & 19.48 & $\$ 11.33$ \\
\hline Cow Butte & weathered & 12.51 & 12.62 & 12.74 & 14.32 & 15.34 & 16.00 & 17.69 & 18.24 & 19.48 & $\$ 10.55$ \\
\hline Olson Draw & 10.23 & 11.37 & 12.63 & 13.50 & 14.41 & 15.28 & 16.44 & 17.79 & 19.48 & 20.04 & $\$ 12.13$ \\
\hline \multicolumn{12}{|c|}{ Almond Formation, Mesaverde Group } \\
\hline Cow Creek Butte & weathered & 12.52 & 12.63 & 12.74 & 14.31 & 14.90 & 16.00 & 16.44 & 18.24 & 19.48 & $\$ 14.91$ \\
\hline Robertson & weathered & 10.51 & 11.81 & 13.27 & 13.50 & 15.21 & 16.00 & 17.01 & 17.41 & 18.24 & $\$ 14.30$ \\
\hline
\end{tabular}


Table 7. Recoverable coal resources by stripping ratio for coal beds containing more than 40 million short tons in the Little Snake River coal bed and Red Desert assessment area, Greater Green River Basin, Wyoming.

[green-shading represents stripping ratio increments where coal resources can be classified as reserves, based on values in table 6]

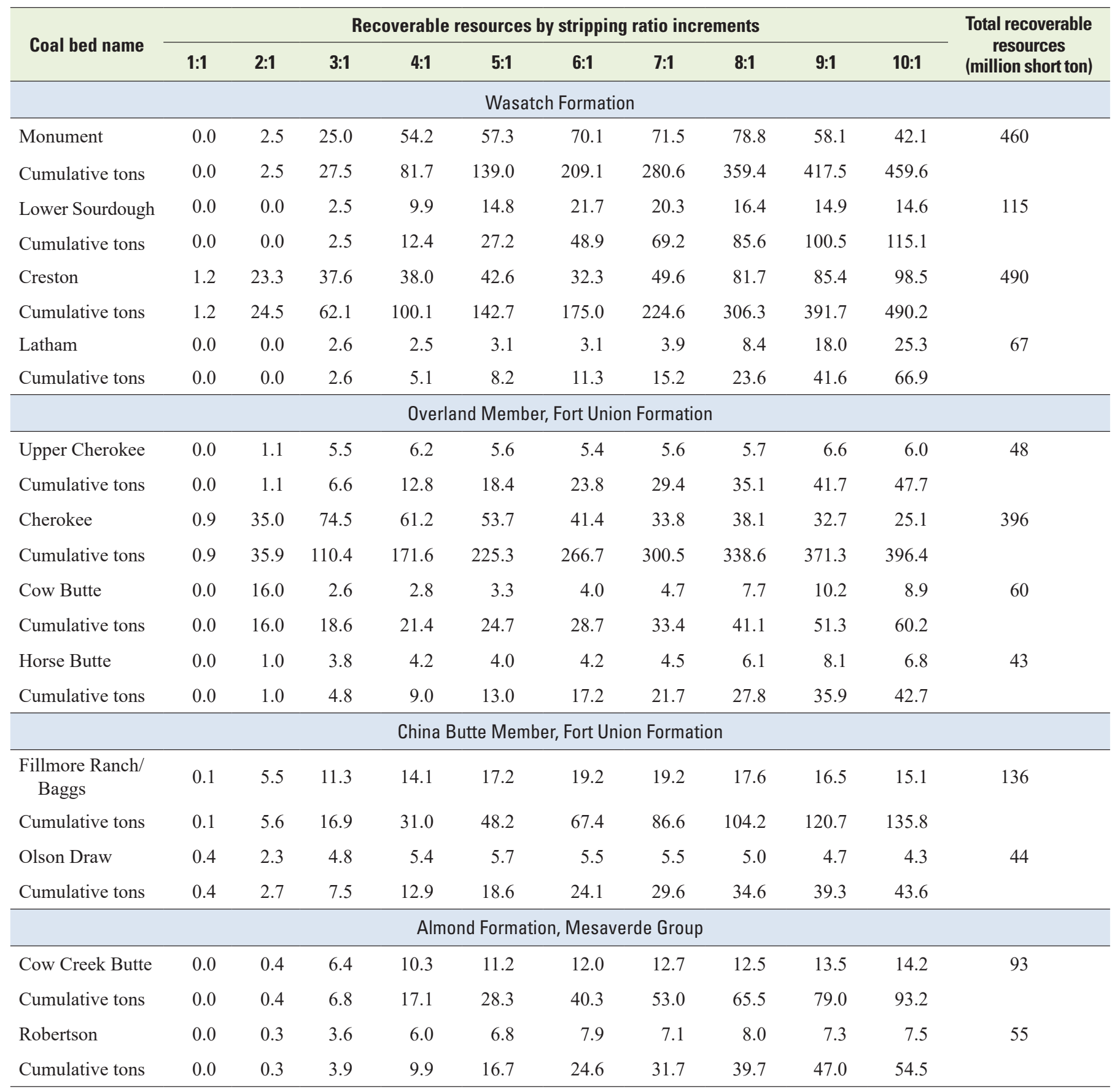


Table 8. Geotechnical correlations between Hanna Basin and Little Snake River coal field and Red Desert assessment area, Greater Green River Basin, Wyoming.

[psi/ft, pound per square inch per foot of depth; psi, pound per square inch]

\begin{tabular}{lll}
\hline \multicolumn{1}{c}{ Correlation characteristic } & \multicolumn{1}{c}{ Hanna Basin ${ }^{1}$} & \multicolumn{1}{c}{$\begin{array}{c}\text { Little Snake River coal field and Red Desert } \\
\text { assessment area }^{2}\end{array}$} \\
\hline Pressure gradient ${ }^{3}$ & $1.136 \mathrm{psi} / \mathrm{ft}$ measured & $1.14 \mathrm{psi} / \mathrm{ft}$ \\
\hline Entry component strengths & $1.139 \mathrm{psi} / \mathrm{ft}$ calculated & Roof: $1,900 \mathrm{psi}$ \\
& Weak floor: $1,410-3,520 \mathrm{psi}$ & Coal: $2,560 \mathrm{psi}$ \\
& Soft coal: $1,270-2,568 \mathrm{psi}$ & Floor: $5,00 \mathrm{psi}$ \\
\hline Entry width & Weak floor: $4,070-5,740 \mathrm{psi}$ & 18 feet \\
\hline Chain pillarsize & 18 feet & 80 feet wide, \\
& 82 feet wide, & 160 feet long \\
\hline Coal (mined thickness) & 164 feet long & Variable \\
\hline
\end{tabular}

${ }^{1}$ Data are from Barron and DeMarco (1995).

${ }^{2}$ Estimated.

${ }^{3}$ Measured pressure gradient for Shoshone No. 1 Mine and calculated pressure gradient using Shoshone drill hole DH-104 to estimate overburden weight of 164 pounds per cubic foot for a 600 -foot interval with average rock densities from various sources.

Table 9. Average weekly coal commodity spot prices.

[Table 9 data are for week ending June 10, 2019, from U.S. Energy Information Administration (2019a)]

\begin{tabular}{lcccl}
\hline \multicolumn{1}{c}{ Region } & $\begin{array}{c}\text { British Thermal Unit per } \\
\text { short ton }\end{array}$ & Percent sulfur dioxide & $\begin{array}{c}\text { Price } \\
\text { (dollar per short ton) }\end{array}$ & \multicolumn{1}{c}{ Notes } \\
\hline Northern Appalachia & 13,000 & less than 3.0 & 53.40 & Low to high volume bituminous \\
Central Appalachia & 12,500 & 1.2 & 59.25 & Low to high volume bituminous \\
Illinois Basin & 11,800 & 5.0 & 39.10 & Medium to high volume bituminous \\
Uinta Basin & 11,700 & 0.8 & 35.90 & High volume bituminous B-C \\
Powder River Basin & 8,800 & 0.8 & 12.30 & Subbituminous B-C \\
\hline
\end{tabular}





\section{Glossary}

This assessment includes determinations of original, available, and recoverable coal resources and reserves. This terminology has been used in many U.S. Geological Survey coal studies (for example, Wood and others, 1983; Carter and Gardner, 1989; Eggleston and others, 1990; Molnia and others, 1999).

\section{A}

available coal resources The remaining coal resources thick and shallow enough to be mined by either surface or underground methods and unencumbered by land-use, environmental, societal, regulatory, or technologic restrictions as they may apply in a specific State or region (Carter and Gardner, 1989).

\section{C}

coalbed methane A primary coal seam gas collected from unmined coal beds (Clarke Energy, [2013]).

coal reserves Virgin or accessed parts of a coal reserve base that could be economically extracted or produced at the time of determination considering environmental, legal, and technologic constraints. The term "reserves" need not signify that extraction facilities are in place or operative. Reserves include only recoverable coal; thus, terms such as "extractable reserves" are redundant and are not a part of the classification system (Wood and others, 1983). Reserves can be categorized as "measured" and "indicated," as underground or surface minable, by thickness of overburden, by thickness of coal in the bed, and by various quality factors.

coal reserve base The tonnage estimate for coal consisting of the sum of the estimates for measured and indicated reserves, marginal reserves, and a part of the measured and indicated subeconomic resources (Wood and others, 1983).

coal resources Naturally occurring concentrations or deposits of coal in the Earth's crust in such forms and amounts that economic extraction is currently or potentially feasible (Wood and others, 1983).

continuous mining where the continuous mining machine cuts or rips coal from the face of an underground mine and loads it onto conveyors or into shuttle cars in a continuous operation (Thrush, 1968). Continuous mining can be used as a stand-alone extraction process or in conjunction with longwall mining to provide access to the areas or panels to be extracted by longwall methods.

\section{D}

demonstrated reserve base The total coal mapped to measured and indicated degrees of accuracy and found at depths and in coalbed thickness considered technologically minable at the time of determination (U.S. Energy Information Administration, 2015b).

dip The angle at which a bed, stratum, or vein is inclined from the horizontal axis (Thrush, 1968).

discounted cash flow The stream of the net after-tax cash flows where the cash outlays include all operating costs, taxes, and investment costs, and where revenues include cash payments of product sales (Association for the Advancement of Cost Engineering, 1997).

\section{$\mathbf{F}$}

fault A fracture or fracture zone along which there has been displacement of the two sides relative to one another parallel to the fracture (Thrush, 1968).

\section{H}

hypothetical resources Tonnage estimates computed by extrapolation of thicknesses of coal for a radius greater than 3 miles (mi; 4.8 kilometers $[\mathrm{km}]$ ) from a point of measurement. Hypothetical resources are a class of undiscovered resources either similar to known coal deposits that may be reasonably expected to exist in the same or region under analogous geologic conditions or are an extension from inferred resources (Wood and others, 1983). 
I

indicated resources Tonnage estimates computed by extrapolation of thicknesses of coal for a radius of 0.25 to $0.75 \mathrm{mi}$ ( 0.4 to $1.2 \mathrm{~km}$ ) from a point of measurement (Wood and others, 1983).

inferred resources Tonnage estimates computed by extrapolation of thicknesses of coal for a radius of 0.75 to $3 \mathrm{mi}$ ( 1.2 to $4.8 \mathrm{~km}$ ) from a point of measurement (Wood and others, 1983).

interburden A layer of sedimentary rock, of any composition and thickness, that separates two minable coal beds (Neuendorf and others, 2011). When two potentially minable coal beds occur within a minimum acceptable distance above or below one another, one will not be mined - often the thinner of the two (Carter and Gardner, 1989).

\section{L}

land-use restrictions Constraints, including industrial and environmental restrictions, placed upon mining by societal policies to protect those surface features or entities that could be harmed by mining. Because laws and regulations can be modified or repealed, the restrictions may change. Specific land-use restrictions include railroads, cities, and towns, airports, and interstate highways.

longwall mining A method of underground mining where a machine shears coal, using rotating drums or a plow, as it is pulled back and forth across a long open face. The sheared and loosened coal falls onto a mechanical conveyor and is removed from the mine (National Mining Association, 2016). Large blocks of coal or panels where the open face width is up to $1,500 \mathrm{ft}$ and panel lengths are up to $20,000 \mathrm{ft}$ are removed entirely. Panels are accessed using continuous mining methods. Longwall mining is the most productive underground coal mining method.

\section{M}

measured resources Tonnage estimates computed by extrapolation of thicknesses of coal for a radius of $0.25 \mathrm{mi}(0.4 \mathrm{~km})$ from a point of measurement (Wood and others, 1983).
0

original coal resource The total amount of coal remaining before production. Where mining has occurred, the total of original resources is the sum of the identified resources, undiscovered resources, coal produced, and coal lost in mining (Wood and others, 1983).

overburden Rock, including coal or unconsolidated material, that overlies a specified coal bed. Overburden is reported in feet or meters and is used to classify the depth to an underlying coal bed (Wood and others, 1983).

outcrop That part of a rock formation (coal bed) that appears at the surface of the ground (Thrush, 1968).

\section{$\mathbf{P}$}

parting A thin layer of stratum or noncoal material within a coal bed that does not exceed the thickness of coal in the directly underlying or overlying benches (Wood and others, 1983).

previously mined coal Coal that has already been extracted from a deposit (Association for the Advancement of Cost Engineering, 1999).

\section{$\mathbf{R}$}

recoverable coal resource Coal that is or can be extracted from a coal bed during mining regardless of cost. The term "recoverable" should be used in combination with "resources" and not with "reserves" (Wood and others, 1983).

reliability category A category based on the distance from points of measurement or sampling (Wood and others, 1983). The measured, indicated, inferred, and hypothetical resource categories indicate the relative reliability of tonnage estimates related to distance from points of thickness control of particular parts of a coal deposit. The reliability categories are not indicative of the reliability of the basic data (that is, the accuracy of coal measurements or the accuracy of location of the coal outcrop). It is assumed that all basic data used in resource estimation have been judged reliable by the estimator and that unreliable data have been discarded.

remaining resources Coal resources remaining in the ground after subtracting coal that has been previously mined from the original resource (Wood and others, 1983).

restrictions to mining Land-use restrictions, technical limitations, and unsuitability criteria that would prohibit mining. 
S

stripping ratio The volume of overburden or interburden (waste) that must be removed to gain access to a unit amount of coal (ratio of waste to recovered material). For this assessment, the ratio is expressed as cubic yards of overburden to short tons of coal. The stripping ratio can be approximated by dividing the total thickness of waste by the total thickness of coal. For example, given two coal beds each $5 \mathrm{ft}$ thick at 50 and $105 \mathrm{ft}$ in depth, the total waste and coal thicknesses would be 100 and $10 \mathrm{ft}$ respectively. A simple ratio would be 10:1, but a stripping ratio would be 9.1:1 (Thrush, 1968).

surface mining Mining at or near the ground surface, generally done where the overburden can be removed economically. A strip mine is a surface mine in which the overburden is removed from a coalbed before the coal is removed (Thrush, 1968).

\section{T}

technical restrictions Constraints, relating to economics and safety, placed upon mining by the state of technology or prescribed by law. These restrictions can change with advances in science and technology or modifications in the law. In this report, some geologic factors are included as technical restrictions.

\section{U}

underground mining Mining where extraction occurs beneath the ground surface and is generally done when surface mining is not economical.

unsuitability criteria Specific legal constraints used to determine if an area can be mined by surface mining methods. These include, but are not limited to, Federal land systems, dwellings, and alluvial valley floors.

underground mining Mining where extraction occurs beneath the ground surface and is generally done when surface mining is not economical.

Publishing support provided by:

Denver Publishing Service Center, Denver, Colorado

Pembroke Publishing Center, Pembroke, New Hampshire

For more information concerning this publication, contact:

Center Director, USGS Central Energy Resources Science Center

Box 25046, Mail Stop 939

Denver, CO 80225

(303) 236-1647

Or visit the Central Energy Resources Science Center Website at:

https://www.usgs.gov/energy-and-minerals/energy-resources-program/

This publication is available online at:

https://doi.org/10.3133/pp1836 
